
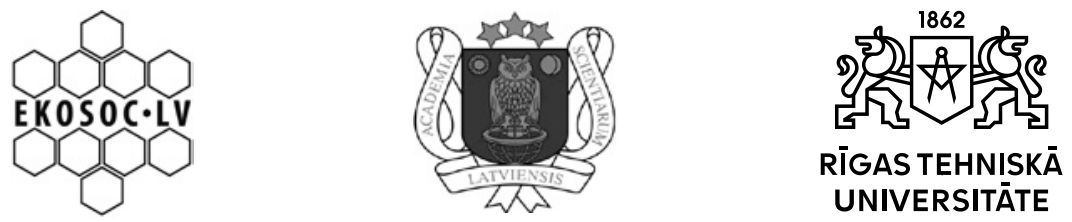

\title{
SOCIĀLĀ INOVĀCIJA: IZAICINĀJUMI UN RISINĀJUMI LATVIJĀ
}

\author{
Zinātniskā redaktore \\ Karine Oganisjana
}

\section{Zinātniskā monogrāfija}

Apstiprinājusi RTU Zinātnes padome 2019. gadā

Recenzenti: Anda Zvaigzne Andra Fernāte Ludmila Aleksejeva

RTU Izdevniecība

Rìga 2019 


\section{Autoru kolektīvs}

Rīgas Tehniskā universitāte

Karine Oganisjana

Yuliya Eremina

Konstantins Kozlovskis

Salome Gvatua

Tālis Laizāns

Benjamin Ngongo Kabwende

Nicolás Monge-Iriarte

Ozoemena Joseph Chukwu

Latvijas Universitāte

Svetlana Surikova

Latvijas Lauksaimniecības universitāte

Gunta Grīnberga-Zālīte

Lāsma Līcīte

Rīgas Stradina universitāte

Tatjana Koke

Latvijas Zinātṇu akadēmija

Laura Jeroščenkova 


\section{Authors}

Riga Technical University

Karine Oganisjana

Yuliya Eremina

Konstantins Kozlovskis

Salome Gvatua

Tālis Laizāns

Benjamin Ngongo Kabwende

Nicolás Monge-Iriarte

Ozoemena Joseph Chukwu

Universiy of Latvia

Svetlana Surikova

Latvia University of Life Sciences

and Technologies

Gunta Grīnberga-Zālīte

Lāsma Lìcīte

Riga Stradiṇš University

Tatjana Kokge

Latvian Academy of Sciences

Laura Jeroščenkova 
Karine Oganisjana, Gunta Grīnberga-Zālīte, Svetlana Surikova, Konstantins Kozlovskis, Lāsma Līcīte, Tālis Laizāns, Nicolás Monge-Iriarte, Tatjana Koķe, Laura Jeroščenkova, Yuliya Eremina, Salome Gvatua, Benjamin Ngongo Kabwende, Ozoemena Joseph Chukwu. Sociālā inovācija: izaicinājumi un risinājumi Latvijā. Zinātniskā monogrāfija. Rīga, RTU Izdevniecība, 2019. 148 lpp.

Monogrāfijā ir starpdisciplināri pētīta sociālā inovācija, tās būtība, ietekme uz sabiedrības ilgtspējīgu attīstību, to veicinošie un kavējošie faktori, kā arī šksēršlsi un to pārvarēšanas panēemieni, analizēta iesaistīto pušu rīcība un to līdzdalības dimensijas, aplūkoti attīstības scenāriji un labas prakses piemēri Latvijā un citās Eiropas valstīs, izstrādāta sabiedrības finansiālās, informatīvās un organizatoriskās iesaistes sociālās inovācijas procesos indeksu koncepcija un šo indeksu aprēksināšanas metodologiija. Darbā analizēti arī līdz šim Latvijā sociālās inovācijas īstenošanai nepielietoti finansējuma avoti. Monogrāfija paredzēta sociālās inovācijas pētniekiem, praktiḳiem, sociālajiem uzṇēmējiem, politikas veidotājiem, pašvaldību vadītājiem, pedagogiem un izglītības iestāžu vadītājiem, studentiem un visiem, kas interesējas par sociālo inovāciju un tās veicināšanas jautājumiem.

\section{Recenzenti}

asoc. profesore Anda Zvaigzne, Rēzeknes Tehnologiiju akadēmija profesore Andra Fernāte, Latvijas Sporta pedagoğijas akadēmija docente Ludmila Aleksejeva, Daugavpils Universitāte

\section{Zinātniskā redaktore}

asoc. profesore Karine Oganisjana, Rīgas Tehniskā universitāte

Zinātniskā monogrāfijas apstiprināta publicēšanai RTU Zinātnes padomes 2019. gada 18. februāra sēdē, protokola Nr. 04000-3/3.

Monogrāfija "Sociālā inovācija: izaicinājumi un risinājumi Latvijā" izdota Valsts pētījumu programmas "EKOSOC-LV" ("Tautsaimniecības transformācija, gudra izaugsme, pārvaldība un tiesiskais ietvars valsts un sabiedrības ilgtspèjīgai attīstībai - jaunas pieejas ilgtspējīgas zināšanu sabiedrības veidošanai") projekta 5.2.7. "Sabiedrības iesaiste sociālās inovācijas procesos Latvijas ilgtspējīgas attīstības nodrošināšanai" ietvaros.

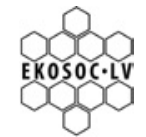

Zinātniskā monogrāfija izdota ar RTU Zinātnes atbalsta fonda finansiālu atbalstu.

Literārā redaktore Inga Skuja

Maketa dizains Paula Lore

Vāka dizains Paula Lore

(C) Rīgas Tehniskā universitāte, 2019

https://doi.org/10.7250/9789934222290

ISBN 978-9934-22-228-3 (print)

ISBN 978-9934-22-229-0 (pdf) 
Karine Oganisjana, Gunta Grīnberga-Zālīte, Svetlana Surikova, Konstantins Kozlovskis, Lāsma Līcīte, Tālis Laizāns, Nicolás Monge-Iriarte, Tatjana Koḳe, Laura Jeroščenkova, Yuliya Eremina, Salome Gvatua, Benjamin Ngongo Kabwende, Ozoemena Joseph Chukwu. Social Innovation: Challenges and Solutions in Latvia. Scientific monography. Riga, RTU Print, 2019. 148 pp.

The monograph presents interdisciplinary research on social innovation, its essence and impact on sustainable development of society, its promoting and hindering factors and the ways how the obstacles are overcome. It analyses the stakeholders and their input in social innovation processes, considering also the scenarios of the development of social innovation in Latvia and the cases of best social innovation practices from Latvia and other European countries. The monograph provides also the analysis of the new concept of the indices of financial, informative and organizational involvement of stakeholders in social innovation processes with the research and calculation methodology elaborated by the research team. There is also the analysis of the sources of financing so far not used in Latvia for the implementation of social innovation.

The work is intended for social innovation researchers, practitioners, social entrepreneurs, policy makers, heads of municipalities, educators and heads of educational institutions, students and all other individuals interested in social innovation and its promotion issues.

\section{Reviewers}

Assoc. professor Anda Zvaigzne, Rezekne Academy of Technologies

Professor Andra Fernāte, Latvian Academy of Sports Education

Docent Ludmila Aleksejeva, Daugavpils University

\section{Scientific editor}

Assoc. professor Karine Oganisjana, Riga Technical University

The monograph is published in accordance with the resolution of RTU Scientific Council of 18 February, 2019, minutes No. 04000-3/3.

The monograph "Social Innovation: Challenges and Solutions in Latvia" is published within the project 5.2.7. "Involvement of the Society in Social Innovation for Providing Sustainable Development of Latvia" of the National Research Programme "Economic Transformation, Smart Growth, Governance and Legal Framework for the State and Society for Sustainable Development - a New Approach to the Creation of a Sustainable Learning Community (EKOSOC-LV)".

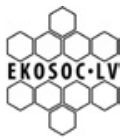

The scientific monograph is published with the financial support from RTU Research Support Fund.

Literary editor Inga Skuja

Design Paula Lore

Cover designer Paula Lore

(C) Riga Technical University, 2019

https://doi.org/10.7250/9789934222290

ISBN 978-9934-22-228-3 (print)

ISBN 978-9934-22-229-0 (pdf) 


\section{SOCIAL INNOVATION: CHALLENGES AND SOLUTIONS IN LATVIA}

The promotion of social innovation has become one of the priorities of the European Union as a crucial factor which enhances the quality of life and promotes sustainable development and competitiveness of a country. In order to promote openness and active participation in socio-economic processes, it is necessary to develop existing forms of social innovation and introduce new ones, providing a legal basis for their activities. This is related to the full use of human resources in the process of social innovation, the development of social capital, social participation and education for social innovation. Since the concept of social innovation is new in Latvia, this issue has not been studied sufficiently; besides, there is not a legal basis for social innovation at the national level. Of course, the recently adopted law on social entrepreneurship improves the situation on the solution of social problems in the country. However, it is important to emphasize that the matter of social innovation differs from social entrepreneurship. If social entrepreneurship is aimed at creating new businesses with social impact, social innovation from the very beginning is intended to solve topical social problems in the society, but not with the guaranteed transformation of it into businesses. Although, in some cases, the initiative and successful solutions of social problems can scale and turn also into a possibility for businesses.

This monograph presents the findings of the study on social innovation conducted by the research project "Involvement of the Society in Social Innovation for Providing Sustainable Development of Latvia" within the National Research Programme "EKOSOC-LV" ("Transformation of Economy, Smart Growth, Governance and Legal Framework for Sustainable Development of the State and Society New Approaches to Creating a Sustainable Knowledge Society") from 2014 to 2018. The project team represented researchers and Doctoral and Master's students from four universities of Latvia: Riga Technical University, the University of Latvia, Latvia University of Life Sciences and Technologies, and Riga Stradiňš University. The research team was international having also a researcher and social innovation practitioner from Chile, and Master's students from Latvia, Nigeria, Congo, Georgia, Uzbekistan, and India who studied at the Faculty of Engineering Economics and Management of Riga Technical University. 


\section{The aim of the monograph}

The aim of the monograph "Social innovation: challenges and solutions in Latvia" is to analyse the opportunities for the involvement of the society in social innovation processes in Latvia for its sustainable development.

\section{The monograph analyses:}

- the matter of social innovation;

- the impact of social innovation on the sustainable development of the society (Oganisjana \& Surikova, 2015);

- challenges faced in social innovation research and the solutions elaborated (Oganisjana, Surikova \& Grīnberga-Zālīte, 2016; Počs et al., 2018);

- factors that influence social innovation (Oganisjana, Surikova \& Laizāns, 2015);

- barriers to social innovation and the mechanisms of overcoming them in Latvia (Oganisjana et al., 2017b);

- stakeholders and dimensions of their support and involvement in social innovation processes; the methodology of determining the financial, organizational and informative involvement of the society in social innovation processes (Oganisjana, Surikova, Kozlovskis \& Svirina, 2018);

- social innovation development scenarios in Latvia (Dobele, Grinberga-Zalite \& Kelle, 2015);

- examples of the best practices in social innovation in Latvia and other European countries;

- ways of attracting financial resources to social innovation;

- the role of public policy in social innovation.

The project team introduced the concept of indices of financial, informative and organizational involvement of the society in social innovation processes and determined them in the case of Latvia having conducted the statistical analysis of quantitative data collected in the interviews of social innovation projects.

The findings of the research have been published in 22 scientific papers in Latvian and international scientific journals, conference proceedings, and monographs. The results of the different stages of the research have been presented and discussed in 43 national and international scientific conferences, forums, and seminars. 


\section{SATURS}

IEVADS: SOCIĀLĀS INOVĀCIJAS PĒTĪJUMA METODOLOG̣IJA ...... 10 Karine Oganisjana

1. SOCIĀLĀS INOVĀCIJAS BŪTĪBA UN IZAICINĀJUMI SOCIĀLĀS INOVĀCIJAS PĒTNIECĪBĀ

Lāsma Līcìte, Svetlana Surikova, Gunta Grīnberga-Zālìte

2. SOCIĀLĀS INOVĀCIJAS NOZĪME SABIEDRĪBAS

ILGTSPĒJĪGĀ ATTĪSTĪBĀ

Svetlana Surikova, Tatjana Koke, Karine Oganisjana

3. SOCIĀLO INOVĀCIJU IETEKMĒJOŠIE FAKTORI

Karine Oganisjana, Svetlana Surikova, Tālis Laizāns

3.1. Pētījumi par sociālo inovāciju

ietekmējošajiem faktoriem

3.2. Sociālo inovāciju ietekmējošie faktori Latvijā

4. SOCIĀLĀS INOVĀCIJAS ŠĶĒRŠLI UN TO PĀRVARĒŠANAS

LĪDZEKḶI UN MEHĀNISMI LATVIJĀ

Karine Oganisjana, Yuliya Eremina, Salome Gvatua,

Benjamin Ngongo Kabwende, Ozoemena Joseph Chukwu

4.1. Pētījuma īstenošanas konteksts

4.2. Pētījuma organizācija

4.3. Datu analīzes veikšanas logika

4.4. Galvenie sociālās inovācijas škēēšlı Latvijā

4.5. Kā Latvijā tiek pārvarēti sociālās inovācijas škēêṣ̌li ..........

4.6. Sociālās inovācijas šḳēršlu un to pārvarēšanas līdzekḷu un mehānismu kopanalīze

5. SABIEDRĪBAS FINANSIĀLĀ, INFORMATĪVĀ, ORGANIZATORISKĀ UN KOPĒJĀ IESAISTE SOCIĀLĀS INOVĀCIJAS PROCESOS LATVIJĀ

Karine Oganisjana, Nicolas Monge-Iriarte, Konstantins Kozlovskis, Tālis Laizāns, Svetlana Surikova

\subsection{Sociālās inovācijas projektu intervijas} materiālu izstrāde

5.2. Sabiedrības finansiālās, informatīvās, organizatoriskās un kopējās iesaistes sociālās inovācijas procesos 
6. SOCIĀLĀS INOVĀCIJAS FINANSĒŠANAS IESPĒJAS:

ĀRVALSTU PIEREDZES APKOPOJUMS

Tãlis Laizāns

7. SOCIĀLĀS INOVĀCIJAS VEICINĀŠANAS

SCENĀRIJI LATVIJĀ

Lāsma Lìcīte, Gunta Grīnberga-Zālīte

7.1. Sociālās inovācijas veicināšanas scenāriju

izstrāde Latvijas apstākḷiem

7.2. Sociālās inovācijas veicināšanas scenāriju izvērtējums

8. SOCIĀLĀS INOVĀCIJAS PIEREDZE LATVIJĀ:

SOCIĀLĀS PROBLĒMAS UN TO RISINĀJUMI

Gunta Grīnberga-Zālīte, Lāsma Lìcīte, Laura Jeroščenkova

9. SOCIĀLĀS INOVĀCIJAS PĒTNIECĪBAS UN ATTİSTĪBAS

PROJEKTI EIROPAS SAVIENĪBĀ

Tālis Laizāns

9.1. Sociālās inovācijas pieredze Somijā

103

9.2. Sociālās inovācijas projektu pieredze

Eiropas Savienībā

10. SOCIĀLĀ INOVĀCIJA TĀS GLOBĀLAJĀ KONTEKSTĀ

Nicolás Monge-Iriarte

10.1. Nepieciešamība sniegt valdības atbalstu sociālās inovācijas projektiem

10.2. Kā īstenot sociālās inovācijas politiku Latvijā 


\section{IEVADS: SOCIĀLĀS INOVĀCIJAS PËTİJUMA METODOLOG̣IJA}

KARINE OGANISJANA

Sociālās inovācijas veicināšana ir kḷuvusi par vienu no Eiropas Savienības (ES) prioritātēm, jo tā paaugstina sabiedrības dzīves kvalitāti, sekmē valsts ilgtspējīgu attīstību un veicina konkurētspēju. Virkne pētījumu ir parādījuši, ka pastāv korelācija starp sociālās inovācijas aktivitāšu līmeni un inovācijas un uzṇēmējdarbības attīstību valstī (The Economist \& Intelligence Unit, 2013). Lai sekmētu sabiedrības atvērtību un līdzdalību sociāli ekonomiskajos procesos, ir radoši jāattīsta esošās un jāievieš jaunas sociālās inovācijas formas, atbilstoši nodrošinot tām tiesisko vidi. Šie pasākumi ir saistīti ar cilvēkresursu potenciāla pilnvērtīgu izmantošanu sociālās inovācijas procesā, kā arī ar sociālā kapitāla, sociālās līdzdalības un uz sociālo inovāciju orientētas izglītības attīstību. Latvijā sociālās inovācijas koncepcija ir jauna un nav pietiekami pētīta; trūkst valstiski izveidotas regulācijas. 2017. gada oktobrī pieñemtais Sociālā uzṇēmuma likums uzlabos situāciju un palīdzēs radīt sociālajai uzṇēmējdarbībai labvēlīgu vidi. Tomēr ir svarīgi atzīmēt, ka sociālā inovācija atšķiras no sociālās uzṇēmējdarbības pēc būtības. Sociālā uzṇēmējdarbība tiek definēta kā inovatīva biznesa metožu un paṇēmienu pielietošana, lai iegūtu visai sabiedrībai vai atsevišķām tās grupām nozīmīgu labumu, kas saistās ar sociālo un ekonomikas jomu vai apkārtējās vides saglabāšanu (Cornelius et al., 2008; EC, 2013a). Ja sociālās uzṇēmējdarbības mērkịis ir izveidot jaunu biznesu ar sociālo ietekmi, tad sociālās inovācijas mērķis ir risināt aktuālas sociālās problēmas sabiedrībā, kas ne vienmēr var tikt īstenots kā uz peḷnu orientēta komerciāla rakstura darbība. Tajā pašā laikā var veidoties situācijas, kad uzsāktā iniciatīva un kādu sociālo problēmu veiksmīgs risinājums, paplašinoties tā mērogam, var novest pie komerciāla rezultāta un sekmīgas uzṇēmējdarbības.

Valsts pētījumu programmas (VPP) "EKOSOC-LV" ("Tautsaimniecības transformācija, gudra izaugsme, pārvaldība un tiesiskais ietvars 
valsts un sabiedrības ilgtspējīgai attīstībai - jaunas pieejas ilgtspējīgas zināšanu sabiedrības veidošanai") projektā "Sabiedrības iesaiste sociālās inovācijas procesos Latvijas ilgtspējīgas attīstības nodrošināšanai" (2014.-2018. g.) tika starpdisciplināri pētīti dažādi sociālās inovācijas aspekti ekonomikas, pārvaldības, sabiedrības, likumdošanas, zinātnes un izglītības skatījumā. Projekta ietvaros veiktā pētījuma posmi ar visām tā īpatnībām un galvenajām atziṇām veido šīs monogrāfijas pamatu.

\section{Monogrāfijas mērḳis}

Monogrāfijas "Sociālā inovācija: izaicinājumi un risinājumi Latvijā" mērḳis ir analizēt iespējas sabiedrības iesaistei sociālās inovācijas procesos Latvijā tās ilgtspējīgas attīstības nodrošināšanai.

\section{Monogrāfijā tiek analizēti:}

- sociālās inovācijas būtība un ietekme uz sabiedrības ilgtspējīgu attīstību (Oganisjana \& Surikova, 2015);

- izaicinājumi sociālās inovācijas pētniecībā un izstrādātie risinājumi (Oganisjana, Surikova \& Grīnberga-Zālīte, 2016; Počs et al., 2018);

- sociālo inovāciju veicinošie un kavējošie faktori (Oganisjana, Surikova \& Laizāns, 2015) un sociālās inovācijas šķēršlu pārvarēšanas līdzekḷi un mehānismi (Oganisjana et al., 2017b);

- sociālās inovācijas procesā iesaistītās puses un to līdzdalības dimensijas;

- metodologija, lai noteiktu sabiedrības finansiālo, organizatorisko un informatīvo iesaisti sociālās inovācijas procesos (Oganisjana, Surikova, Kozlovskis un Svirina, 2018);

- sociālās inovācijas attīstības scenāriji Latvijā (Dobele, GrinbergaZalite \& Kelle, 2015);

- sociālās inovācijas labas prakses piemēri Latvijā un citās Eiropas valstīs;

- veidi, kā piesaistīt finanšu resursus sociālajai inovācijai;

- sociālās inovācijas politikas jautājumi.

Lai noteiktu ieinteresēto pušu iesaisti sociālās inovācijas procesos, tika izstrādāta sabiedrības finansiālās, informatīvās un organizatoriskās 
iesaistes indeksu koncepcija. Šie indeksi tika noteikti Latvijas gadījumā, statistiski analizējot kvantitatīvos datus, kurus ieguva, veicot sociālās inovācijas projektu dalībnieku intervijas.

\section{Izmantotās pētījuma metodes}

\section{Datu vākšana:}

- zinātniskās literatūras, ES dokumentu un interneta avotu analīze sociālās inovācijas būtības, škēeršșu un to pārvarēšanas pieredzes izpētei Eiropā un citur pasaulē;

- fokusgrupas diskusija ar uzñēmējdarbības, izglītības, sporta, komunikācijas un labdarības jomu pārstāvjiem un diskusijas videoieraksta transkriptu sagatavošana, lai izpētītu sabiedrības izpratni par sociālās inovācijas būtību, lomu un ietekmi uz sabiedrības attīstību, kā arī par sociālo inovāciju ietekmējošiem faktoriem un to piemēriem Latvijā;

- intervijas ar valsts un privātā sektora uzñēmumu, Ekonomikas ministrijas un NVO pārstāvjiem par sociālās inovācijas attīstības iespējām Latvijā;

- dažādu jomu sociālās inovācijas projektu pārstāvju intervija, lai analizētu sociālās inovācijas šķēršlus un to pārvarēšanas mehānismus, kā arī lai veiktu sabiedrības finansiālās, informatīvās un organizatoriskās iesaistes izpēti Latvijā.

\section{Datu analīze:}

- fokusgrupas diskusijas videoieraksta transkriptu un intervijās iegūto tekstu kvalitatīvā kontentanalīze ar atvērto kodēšanu sociālās inovācijas kategoriju attīstīšanai;

- scenāriju metode datu analīzē trīs vienlīdz iespējamas nākotnes alternatīvas sociālās inovācijas veicināšanas scenāriju ievirzei Latvijā;

- hierarhiju analīzes metode Latvijas apstākḷos sociālās inovācijas veicināšanai piemērotākā scenārija noteikšanai;

- sociālās inovācijas projektu intervijās iegūto kvantitatīvo datu statistiskā analīze sabiedrības finansiālās, informatīvās un organizatoriskās iesaistes indeksu noteikšanai un ieinteresēto pušu atbalsta līmen,a noteikšanai. 
Projektu īstenoja pētnieki no četrām Latvijas augstskolām: Rīgas Tehniskās universitātes (RTU), Latvijas Universitātes (LU), Latvijas Lauksaimniecības universitātes (LLU) un Rīgas Stradiṇa universitātes (RSU).

\section{Pētījuma komanda:}

- Rīgas Tehniskā universitāte: asoc. prof. Dr. paed. Karine Oganisjana (projekta vadītāja un vadošā pētniece), asoc. prof. Dr. oec. Konstantins Kozlovskis (pētnieks), doc. $M g$. oec. Tālis Laizāns (pētnieks), doc. Dr. oec. Jel̦ena Titko (pētniece), doktorante Iveta Ozolin,a-Ozola (zinātniskā asistente) un Nicolas Monge-Iriarte (zinātniskais asistents);

- Latvijas Universitāte: vadošā pētniece Dr. paed. Svetlana Surikova;

- Latvijas Lauksaimniecības universitāte: asoc. prof. Dr. oec. Gunta Grīnberga-Zālīte (vadošā pētniece) un asoc. prof. Dr. oec. Lāsma Līcīte (pētniece);

- Rīgas Stradiña universitāte: prof. Dr. habil. paed. Tatjana Koḳe (pētniece);

- projekta 2., 3. un 4. posmā pētniecībai pievienojās arī RTU Inženierekonomikas un vadības fakultātes maǵistranti no Latvijas, Uzbekistānas, Kongo, Nigērijas, Gruzijas un Indijas, kuri K. Oganisjanas vadītā studiju kursa "Mūsdienu pētījumu metodes: teorija un prakse" ietvaros piedalījās sociālās inovācijas projektu intervēšanā, iegūto datu analīzē un atskaišu gatavošanā.

\section{Pētījuma dizains}

Pētījuma "Sabiedrības iesaiste sociālās inovācijas procesos Latvijas ilgtspējīgas attīstības nodrošināšanai” veikšanas saturs un īstenošanas fāzes ir attēlotas pētījuma dizainā (sk. 1. attēlu).

Pētījuma 1. fāzē tika izstrādāta gan starpdisciplināra pētījuma metodologija un dizains, pamatojoties uz zinātniskās literatūras un ES dokumentu analīzi un dažādu valstu sociālās inovācijas veicināšanas pieredzi, n,emot vērā pētījuma mērksi un uzdevumus un ievērojot pētījuma posmu savstarpējo logiku un pēctecību, gan arī pētījuma metodes un tradīcijas atbilstoši projektā pārstāvētajām nozarēm.

Pētījuma 2. fāzē Rīgas Tehniskajā universitātē 2015. gada maijā tika organizēta fokusgrupas diskusija, uzaicinot uzn,ēmējdarbības, izglītības, sporta, komunikācijas un labdarības jomu pārstāvjus. Diskusijas gaitā tika apspriests plašs jautājumu loks par sociālās inovācijas būtības 


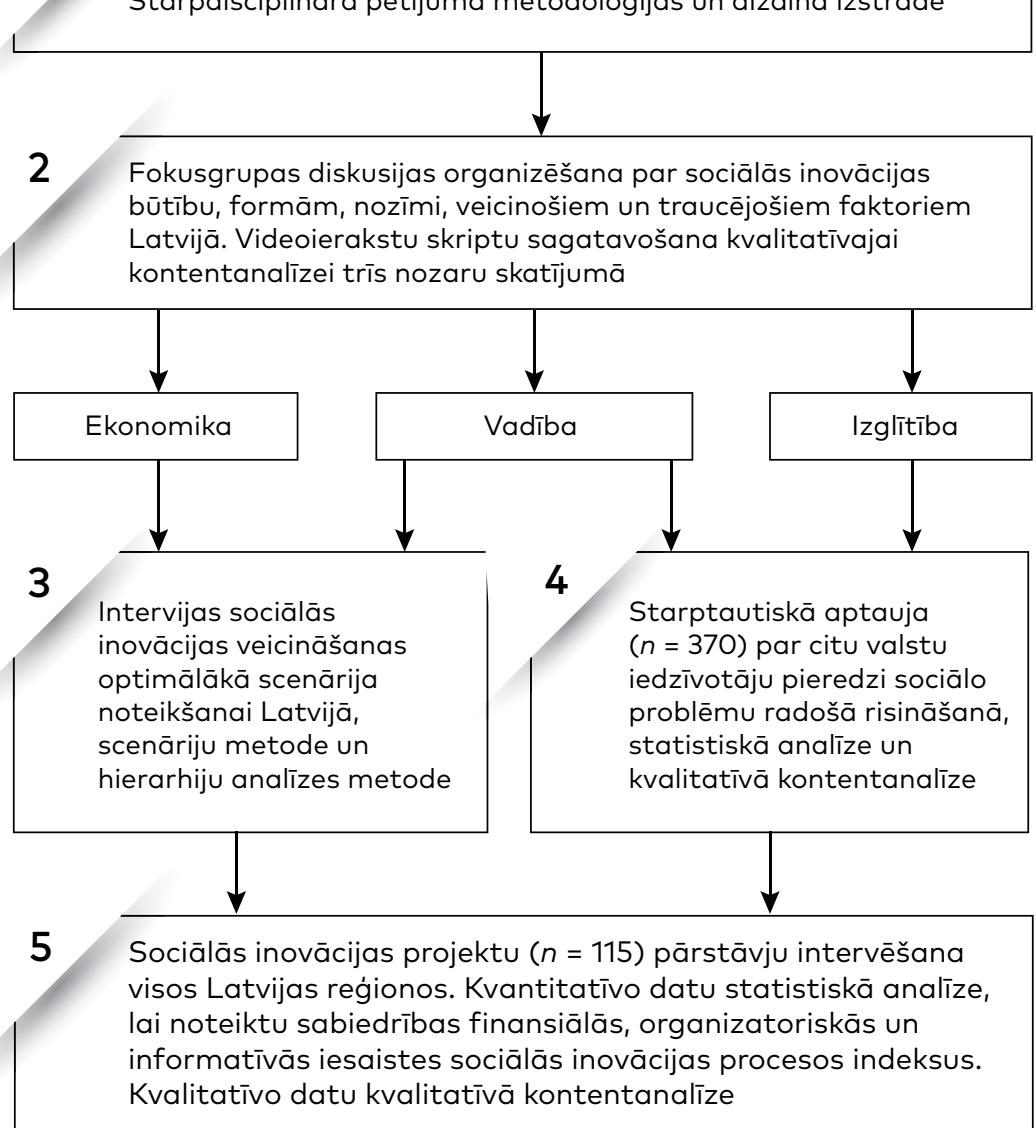

Avots: Simtam pāri. Viedā Latvija, 2018: 170.

1. attēls. Pētījuma "Sabiedrības iesaiste sociālās inovācijas procesos Latvijas ilgtspējīgas attīstības nodrošināšanai" dizains.

izpratni, formām, nozīmi, piemēriem, veicinošiem un traucējošiem faktoriem Latvijā. Tika veikta diskusijas videoierakstu transkriptu kvalitatīvā kontentanalīze. Tā atklāja sociālo inovāciju

- pozitīvi ietekmējošos faktorus - atvērtību jauninājumiem, proaktīvo domāšanu, apzinīgumu, atbildību, piedalīšanos mūžizglītībā, pozitīvo pieredzi, aktīvu dzīves pozīciju un radošo domāšanu;

- negatīvi ietekmējošos faktorus - atvērtības jauninājumiem trūkumu, proaktīvas domāšanas trūkumu, neapzinīgumu, bezatbildību, 
izvairīšanos no līdzdalības mūžizglītībā, pozitīvas pieredzes trūkumu, pasivitāti, konservatīvo domāšanu, lielu varas distanci un birokrātiskos šksēršlus.

Kvalitatīvā kontentanalīze parādīja, ka pastāv trīs faktoru grupas, kas motivē cilvēkus iesaistīties sociālās inovācijas procesos:

1) personu motivējoši iekšējie faktori: empātija, personiskais ieguvums, pašapziña, pieredze un proaktivitāte;

2) starppersonu faktori: sociālā apziṇa, kopradīšanas iespēja, aktīvs dialogs ar iesaistītajām pusēm, savstarpēja mācīšanās, sociālā atbildība;

3) ārējie faktori: atbalsts, atzinība, iedvesmojošie piemēri, līdzdalības iespējas (Oganisjana \& Surikova, 2015).

Fokusgrupas diskusija atklāja iespējamās sociālās inovācijas veicināšanas sadarbības kēēdes starp indivīdiem, uzṇēmumiem, pašvaldībām, valsts institūcijām un nevalstiskajām organizācijām (NVO).

Tika noteikti sociālās inovācijas veicināšanas mehānisma elementi un uz to pamata izstrādāts četru pakāpju sociālās inovācijas veicināšanas modelis:

a) iespēju vai sociālo problēmu apzināšanās;

b) motivēšana mācīties un piedalīties;

c) līdzdomāšana ideju attīstīšanai vai problēmu risināšanai;

d) līdzradīšana ideju vai problēmu risinājumu ieviešanai dzīvē.

Modelis turpmāk tika papildināts ar vēl vienu pakāpi:

e) ideju vai risinājumu izplatīšana sabiedrības praksē un finansiālās patstāvības sasniegšana, n,emot vērā sociālajai inovācijai raksturīgāko - izplatīties un pārveidot sabiedrības domāšanu, praksi un problēmu risināšanas paṇēmienus (Oganisjana, Surikova \& Grīnberga-Zālīte, 2016).

Pētījuma 3. fāzē, balstoties uz fokusgrupas diskusijas rezultātiem, 2015. gada jūnijā-augustā tika veiktas intervijas ar valsts un privātā sektora uzṇēmumu, Ekonomikas ministrijas un NVO pārstāvjiem, lai izpētītu iespējamos sociālās inovācijas veicināšanas scenārijus Latvijā un izvēlētos optimālāko. Izmantojot scenāriju metodi, tika izvirzītas trīs varbūtīgas sociālās inovācijas nākotnes alternatīvas Latvijā:

- valsts pārvaldes aparāta iniciatīvas virzīts scenārijs - sociālā inovācija kā valsts ilgtspējīgas attīstības nosacījums;

- uzñēmumu iniciatīvas virzīts scenārijs - sociālā inovācija kā korporatīvās sociālās atbildības būtiska sastāvdaḷa;

- sabiedrības pašiniciatīvas virzīts scenārijs - sociālā inovācija kā brīvprātīgo darbs.

Hierarhiju analīzes rezultātā, izvērtējot trīs alternatīvos scenārijus, tika noteikts, ka Latvijas apstākḷiem piemērotākais scenārijs sociālās inovācijas veicināšanai varētu būt valsts iniciatīvas virzìts 
scenārijs. Saskaṇā ar to ir nepieciešams izstrādāt atbilstošu normatīvo aktu ietvaru sociālās inovācijas definēšanai un veicināšanai, t. sk. paredzot konkrētus finansiālā un informatīvā atbalsta pasākumus sociālās inovācijas virzìtājiem un īstenotājiem (Dobele, Grinberga-Zalite \& Kelle, 2015).

Pētījuma 4. fāzē, lai iegūtu iespēju salīdzināt situāciju Latvijā un ārvalstīs, 2015.-2016. akadēmiskā gada rudens semestrī tika veikta Eiropas, Āzijas, Amerikas un Āfrikas iedzīvotāju aptauja $(n=370)$ par indivīdu pieredzi sociālo problēmu radošā risināšanā, labuma guvējiem, nozarēm, atbalstītājiem, traucējošiem un veicinošiem faktoriem un mehānismiem, kas nosaka sabiedrības iesaisti sociālās inovācijas procesos. Aptaujā iegūto datu kvalitatīvā kontentanalīze un kvantitatīvā analīze atklāja, ka:

- sociālās problēmas visveiksmīgāk tiek risinātas jomās, kas saistītas ar sociālo aprūpi, vides aizsardzību, veselību, drošību, izglītību, dzīvnieku aprūpi, nabadzības, bezdarba, nevienlīdzības un diskriminācijas novēršanu, bīstamas atkarības, vardarbības un noziedzības samazināšanu, migrāciju un reliğijas jautājumiem;

- sociālo problēmu radošā risināšanā indivīdiem traucē atbalsta, laika, līdzdomātāju un līdzdarbotāju, optimālu risinājumu, finanšu, komunikācijas un piedalīšanās iespēju trūkums;

- sociālo problēmu radošai risināšanai indivīdi iegūst atbalstu no valsts organizācijām, pašvaldībām, darba kolēgiem un vadības, gimenes, draugiem un kaimiṇiem, līdzdomātājiem, uzṇēmējiem un NVO;

- faktori, kas motivē indivīdus iesaistīties sociālo problēmu radošā risināšanā, ir izpratne par sociālajām problēmām, personiskā pieredze, iedvesmojoši piemēri, tieša personiskā saskaršanās ar problēmu, aktīvs dialogs ar sabiedrību, atbalsts un sadarbība, līdzdalības iespējas, izpratne par galveno mērḳi, sociālā sirdsapziṇa un atbildība, empātija un līdzjūtība, atzinība un rezultātu atzīšana, interese, gandarījuma iegūšana no labajiem darbiem, reliǵiozitāte, personīgais ieguvums (Oganisjana et al., 2017a).

Pētījuma 5. fāzē, pamatojoties uz zinātniskās literatūras analīzi, fokusgrupas diskusijās, intervijās ar valsts un privātā sektora uzṇēmumu, Ekonomikas ministrijas un NVO pārstāvjiem un starptautiskās aptaujās gūtajām atziṇām, 2016. gada vasarā tika izstrādāta Latvijas sociālās inovācijas projektu intervijas metodoloǵija un materiāli, lai radītu modeli sabiedrības iesaistei sociālās inovācijas procesos. Šajā darba posmā komandai pievienojās Čìles kolēgis Nicolas Monge-Iriarte, kuram jau bija pieredze sociālās inovācijas veicināšanas praksē Latīn,amerikā, uzturot tiešsaistes platformu www.bottomapp.org. Pēc intervijas materiālu pilotēšanas tika intervēti visu Latvijas reǵionu 
sociālās inovācijas projektu pārstāvji $(n=115)$. Intervijās līdz ar vispārīgo informāciju par projektu mērksiem, mērksa grupām, pārstāvētajām nozarēm, budžetu, nodarbināto skaitu u. c. tika iegūta informācija par projektu uzsākšanas iemesliem, būtiskajiem šksēršlıiem un to pārvarēšanas mehānismiem, problēmu risināšanas analīzi, projektā iesaistīto pušu finansiālo, organizatorisko un informatīvo atbalstu, projekta finansiālo ilgtspējību un ietekmi uz sabiedrību.

Intervijās iegūto kvalitatīvo datu kvalitatīvā kontentanalīze atklāja sociālās inovācijas šḳēršlıus Latvijā, to pārvarēšanas līdzekḷus un mehānismus un sadarbības veidus, kuri iesaistītajām pusēm palīdzēja pārvarēt šos šķēršlıus (Oganisjana et al., 2017b).

Lai noteiktu sabiedrības iesaisti sociālās inovācijas procesos Latvijā, tika izstrādāti sabiedrības finansiālās, informatīvās un organizatoriskās iesaistes sociālās inovācijas procesos indeksi un to noteikšanas metodoloǵija. Statistiski analizējot intervijās iegūtos kvantitatīvos datus, tika noteikti sabiedrības finansiālās, informatīvās un organizatoriskās iesaistes sociālās inovācijas procesos indeksi un analizēta sabiedrības iesaistes dinamika Latvijā laikā no 2003. gada līdz 2017. gadam.

Pētījuma rezultāti tika publicēti 22 zinātniskajos rakstos starptautiskajos un Latvijas zinātniskajos žurnālos, konferenču rakstu krājumos un monogrāfijās. Pētījuma rezultāti tika prezentēti 43 starptautiskajās zinātniskajās konferencēs, forumos un semināros, kā arī tika rīkotas četras starptautisko konferenču EKOSOC-LV apakšsekcijas. Projekta ietvaros tika izveidots jauns produkts - "The secret power of pyramids" -, kas paredzēts kritiskās domāšanas, pētniecisko prasmju un socializācijas veicināšanai sabiedrībā. Latvijas Republikas Patentu valdē 2015. gada 20. decembrī tika reǵistrēts šì produkta dizainparaugs "Piramīdu komplekts pētniecībai un socializācijai”, reǵ. Nr. D15587, dizaineri A. Irbe un K. Oganisjana (Latvijas Republikas Patentu valde, 2015: 1925-1926).

\section{Monogrāfijas struktūra}

Monogrāfiju veido 10 nodaḷas, ko papildina ievads, izmantoto informācijas avotu saraksts, pielikumi un kopsavilkums latviešu un anglu valodā.

1. nodaḷā "Sociālās inovācijas būtība un izaicinājumi sociālās inovācijas pētniecībā" tika analizētas sociālās inovācijas teorijas un tās attīstība, kā arī izstrādāta sociālās inovācijas definīcija, ngemot vērā pētījumos iegūtos rezultātus.

2. nodaḷā "Sociālās inovācijas nozīme sabiedrības ilgtspējīgā attīstībā" tika kombinēti sociālās inovācijas teorētiskās izpētes un 
RTU organizētās fokusgrupas diskusijas rezultāti. Tika secināts, ka sociālā inovācija izraisa daudzpusīgas pozitīvas pārmaiṇas sabiedrībā, veicinot personības izaugsmi, indivīdu sadarbību un sadarbības prasmi, kas ir būtiski sabiedrības attīstību nosakoši faktori.

3. nodạ̣ā "Sociālo inovāciju ietekmējošie faktori" fokusgrupas diskusijas videoierakstu skriptu kvalitatīvā kontentanalīze parādīja, ka atvērtība jaunai pieredzei, proaktīvā domāšana, atbildība un aktīva dzīves pozīcija tiek uzskatītas par sociālo inovāciju veicinošiem faktoriem. Turpretī kā sociālo inovāciju kavējoši faktori tika norādīti indivīdu un sabiedrības kopumā pasivitāte, atvērtības trūkums jaunai pieredzei, radošās domāšanas trūkums un birokrātiskie šksēršlsi.

4. nodaḷā "Sociālās inovācijas šksēršl̦i un to pārvarēšanas līdzekḷi un mehānismi Latvijā" tika analizēti sociālās inovācijas projekti un to organizācija, kā arī veikta datu analīze un noteikti galvenie sociālās inovācijas šḳēršli Latvijā un līdzekḷi to pārvarēšanai. Tika secināts, ka sociālās inovācijas šḳēršli izpaužas trīs dimensijās indivīda, sabiedrības kopumā un formāli tiesiskajā. Šie šk̦ēršlı li tiek pārvarēti, galvenokārt pateicoties informācijas izplatīšanas un popularizēšanas pasākumiem, kā arī saṇemot ārējo finansiālo, organizatorisko un informatīvo atbalstu.

5. nodạ̣ā "Sabiedrības finansiālā, informatīvā, organizatoriskā un kopējā iesaiste sociālās inovācijas procesos Latvijā" tika analizēta sociālās inovācijas projektu intervijas materiālu izstrādes logika, pamatota pētījuma metodologija, pētītas sociālajā inovācijā ieinteresētās puses un trīs to iesaistīšanas dimensijas: finansiālā, informatīvā un organizatoriskā. Tika analizēti sabiedrības finansiālās, informatīvās, organizatoriskās un kopējās iesaistes indeksi, kā arī veikta šo indeksu aprēḳināšana, pamatojoties uz sociālās inovācijas projektu intervijās iegūto kvantitatīvo datu statistisko analīzi. Rezultātā noteikts, kuras no projektā iesaistītajām pusēm visvairāk atbalsta sociālos inovatorus Latvijā.

6. nodaḷā "Sociālās inovācijas finansēšanas iespējas: ārvalstu pieredzes apkopojums" tika analizēta ārvalstu pieredze un izdarīts secinājums, ka Latvijā pastāv plašas iespējas sekmīgi izmantot dažādus, līdz šim nepielietotus finansējuma avotus un instrumentus, kas var attīstīt sociālo inovāciju un nodrošināt sociālo uzṇēmumu attīstību.

7. nodaḷā "Sociālās inovācijas veicināšanas scenāriji Latvijā" tika analizēti ekspertu grupas diskusijas rezultāti un, pamatojoties uz 
tiem, tika izstrādāti trīs scenāriji sociālās inovācijas veicināšanai Latvijā:

a) sabiedrības pašiniciatīvas virzīts scenārijs;

b) valsts iniciatīvas virzìts scenārijs;

c) uzṇēmumu iniciatīvas virzīts scenārijs. Pielietojot hierarhijas analīzes metodi, tika secināts, ka optimālais scenārijs Latvijā ir valsts iniciatīvas virzīts scenārijs.

8. nodaḷā "Sociālās inovācijas pieredze Latvijā: sociālās problēmas un to risinājumi" tika secināts, ka lielākā dal̦a projektu ir sabiedrības pašiniciatīvas virzīti projekti, kas uzsākti, lai apmierinātu kādas nelielas sabiedrības grupas vajadzības. Tādējādi šobrīd Latvijas sociālekonomiskajai situācijai vairāk atbilst sabiedrības pašiniciatīvas virzītais scenārijs.

9. nodal̦ā "Sociālās inovācijas pētniecības un attīstības projekti ES", analizējot ziemel̦u kaimiņvalsts Somijas pieredzi, tika secināts, ka Latvijai ir nepieciešama nacionāla līmeṇa sociālās inovācijas attīstības programma. Tas radītu iespēju plašāka spektra finansējuma pieejamībai, tādējādi paaugstinot valsts un sabiedrības sociālo kapacitāti, un veicinātu iesaistīto partneru sadarbību un sinerǵiju, kā arī sekmētu sociālekonomiskos ieguvumus.

10. nodaḷā "Sociālā inovācija tās globālajā kontekstā" tika analizēts, kādas problēmas globāli pasaulē sociālā inovācija var atrisināt un kādā veidā tā nodrošina sabiedrības ilgtspējīgu attīstību. Tika sniegts arī ārzemju kolēga redzējums par to, kāpēc Latvijas valdībai jāsniedz atbalsts sociālās inovācijas projektu īstenošanā un kā panākt mūsu valsts sabiedrības vajadzībām atbilstošu sociālās inovācijas politiku. 


\section{SOCIĀLĀS INOVĀCIJAS BŪTĪBA UN IZAICINĀJUMI SOCIĀLĀS INOVĀCIJAS PËTNIECĪBĀ}

\section{LĀSMA LĪCĪTE, SVETLANA SURIKOVA, GUNTA GRĪNBERGA-ZĀLITTE}

Viens no pirmajiem pētniekiem, kurš sāka lietot jēdzienu "sociālā inovācija", bija Makss Vēbers (Max Webber) 19. gadsimta beigās. Ar šo jēdzienu viṇš apzīmēja sociālos izgudrojumus.

Kristofers Frīmans (Christopher Freeman) (1988) uzskata, ka Japānas tehnologiiskais progress nebūtu noticis, ja vienlaikus nebūtu notikušas arī izmaiṇas cilvēkresursu izglītības un apmācības sistēmā, kā arī organizatoriskajā sfērā. Tādējādi var secināt, ka sociālā inovācija tiek definēta kā individuālas un/vai institucionālas izmainas ar mērḳi uzlabot organizāciju konkurētspēju, un tā ir cieši saistīta ar tehnologiiskajām un ekonomiskajām inovācijām (Limburg, 2014), kas rada pozitīvu ietekmi gan uz organizāciju darbību (Mahdjoubi, 1997; Thom, 1990; Pot \& Vaas, 2008), gan uz sociālo problēmu risināšanu sabiedrībā kopumā (Mulgan et al., 2007; Tanimato \& Doi, 2007).

Šodien, meklējot dažādu sabiedrībai aktuālu problēmu risinājumus, arvien nozīmīgāka kḷūst arī sociālās inovācijas jēdziena definēšana atbilstīgi jaunās ekonomikas laikmetam. Šo aktualitāti pierāda arī apstāklis, ka vairākās pasaulē atpazīstamās universitātēs, kuras piedāvā mūsdienīgas izglītības programmas, tiek veidoti sociālās inovācijas pētniecības centri (piemēram, Stenfordas biznesa augstskolā). Strauji palielinājies arī to NVO skaits un popularitāte, kuras fokusējas tieši uz sociālo inovāciju radīšanu un ieviešanu (piemēram, The Young Foundation, Centre for Social Innovation Toronto un Centre for Social Innovation Vienna). Izmaiṇas sabiedrības uzskatos ir veicinājušas 
attīstīto pasaules valstu valdību iesaistīšanos šajā sfērā (piemēram, US

Likumsakarīgi sociālās inovācijas ieviešana kḷuvusi aktuāla arī Eiropas Savienībā. Jau kopš 2009. gada Eiropas Komisijas līmenī norisinās pētniecībā diskusijas par sociālās inovācijas iniciatīvām un to ieviešanas iespējām, virzot to kā vienu no praktiskiem risinājumiem pieaugošajām sociālajām vajadzībām ES dalībvalstīs. Īpaša uzmanība sociālajai inovācijai veltīta ES iniciativvas "Inovāciju Savienība" ietvaros. Tā ir viena no "ES 2020" stratēğijas septin̄ām vadošajām iniciatīvām, kuru Eiropas Komisija ir izstrādājusi, lai noteiktu nacionāla, ES un starptautiska mēroga pasākumus, kas būtu īstenojami inovācijas jomā, lai sasniegtu "ES 2020" stratēǵijā noteiktos mērḳus. Stratēǵiskā dokumenta ietvaros sociālā inovācija tiek skaidrota kā iespēja iesaistīt ES pilsonus ekonomiska rakstura aktivitātēs. "Inovāciju Savienības" iniciatīva iezīmē nepieciešamību iestrādāt sociālās inovācijas atbalsta pasākumus 2014.-2020. gada Eiropas Sociālā fonda programmās un aicina dalībvalstis būt aktīvākām sociālās inovācijas projektu atbalstīšanā. Šajā plānošanas posmā pirmo reizi ir izveidota arī atsevišķa atbalsta programma, kas veltīta tieši sociālajai inovācijai (The EU Programme for Employment and Social Innovation) ar kopējo budžetu 919 miljonu eiro apmērā. Tā paredz atbalstu ES dalībvalstīm nodarbinātības un sociālo reformu izstrādei un īstenošanai ES, nacionālajā, reǵionālajā un vietējā līmenī.

Tomēr, neskatoties uz sociālās inovācijas aktualitātes apzināšanos, vēl joprojām problēmas rada fakts, ka pētījumi par sociālo inovāciju tiek veikti dažādās zinātṇu disciplīnās - sociologiijā, ekonomikā un politikas zinātnē -, kā rezultātā atšksiras izpratne par sociālās inovācijas būtību (Rüede \& Lurtz, 2012). Sociālā inovācija ir pētīta arī no dažādu zinātnisko teoriju perspektīvas - strukturācijas teorijas (Pol \& Ville, 2009), uz resursiem balstītas perspektīvas par uzñēmumiem (resourcebased view of the firm) (Dees, 1998; Bloom \& Smith, 2010; Day \& JeanDenis, 2016), klasteru teorijas (Tanimato \& Doi, 2007), tīklu teorijas (Butkeviciene, 2009; Tanimato \& Doi, 2007), sociālās uzṇēmējdarbības (Leadbeater, 1997; Haugh, 2005) un sociālā kapitāla teorijas (Moulaert \& Nussbaumer, 2005). Tādējādi var secināt, ka, lai gan sociālās inovācijas pētījumu spektrs ir l̦oti plašs, tomēr zinātniskajā literatūrā aizvien nav vienotas izpratnes par sociālās inovācijas jēdzienu. Kā atzīst Džefrijs Fefers (Jeffrey Pfeffer), lai veicinātu šì jēdziena izplatību un finansējuma piesaisti sociālās inovācijas pētniecībai un attīstībai, ir būtiski definēt, kas ir sociālā inovācija, un noteikt tās raksturojošos elementus (Pfeffer, 1993).

Sociālās inovācijas būtības definēšanai ir būtiski sākumā izprast katru no šiem jēdzieniem, proti - jēdzienus "inovācija" un "sociāls". 
Zinātniskajā literatūrā pastāv dažādas jēdziena "inovācija” definīcijas, sākot no ḷoti vienkāršām - "jaunas idejas, kas darbojas” - līdz garām un lıoti komplicētām šì jēdziena definīcijām. Džeims Fils (James Phills) un līdzautori (2008) norāda, ka inovāciju raksturo četri būtiski elementi. Pirmkārt, ar inovāciju saprot pašu tās radīšanas procesu - jaunu produktu vai risinājumu radīšanu, kas ietver tehniskos, sociālos un ekonomiskos faktorus. Otrkārt, inovācija ir produkts vai izgudrojums (procesa rezultāts). Treškārt, inovācijas jēdziens ietver inovācijas izplatīšanu un adaptāciju, lai tā tiktu plašāk pielietota. Un, ceturtkārt, inovāciju raksturojošs elements ir arī gala vērtība. Turklāt inovācijai jāietver arī jauninājuma un uzlabojuma elements. Inovācijai nav obligāti jābūt kaut kam oriǵinālam, taču jaunam gan - lietotāja vai inovācijas pieteicēja vajadzībām vai arī attiecīgā konteksta (sabiedrības) ietvaros. Turklāt procesam vai rezultātam jābūt efektīvākam, salīdzinot ar citām alternatīvām, un jāsatur organizatoriskais un vides ilgtspējības elements, proti, inovācijai jādarbojas ilgtermiṇā.

Lai izprastu atšķirību starp inovāciju un sociālo inovāciju, ir būtiski raksturot jēdziena "sociāls" būtību. Terminu "sociāls" dažādi zinātnieki izprot un pielieto atšksirīgi. Galvenokārt tas tiek izmantots, lai raksturotu noteiktas sabiedrības grupas vajadzības vai problēmas, sociālo motivāciju vai nodomus, sociālās vērtības vai lai apzīmētu sociālo sektoru. Sociālās inovācijas kontekstā sociālo vērtību radīšana tiek izprasta kā labumu radīšana sabiedrībai, risinot sociālās problēmas vai apmierinot noteiktas sabiedrības vajadzības, būtiski uzsverot, ka sabiedrības labums ir prioritārs pār personīgā labuma vai pel̦nas gūšanu. Lai arī daudzos gadījumos inovācija ir radījusi labumu sabiedrībai, veicinot nodarbinātību, produktivitātes celšanos un ekonomisko izaugsmi (piemēram, datoru izgudrošana veicināja produktivitātes celšanos un apmācību sistēmas pilnveidošanos; automobiḷu ražošana radīja cilvēkiem lielāku neatkarības un brīvības sajūtu), to ne vienmēr var klasificēt kā sociālu inovāciju. Tādējādi, cenšoties pēc iespējas precīzāk izgaismot sociālās inovācijas būtību, jēgpilni konsolidējot abu iepriekš apskatīto jēdzienu "inovācija" un "sociāls" mūsdienu teorētisko diskursu, virkne autoru ir centušies precizēt sociālās inovācijas jēdziena saturu un piedāvāt tam atbilstīgas definīcijas.

Sociālās inovācijas pētniecībā paralēli tiek lietotas vairākas sociālās inovācijas definīcijas bez skaidra un vienota teorētiskā pamatojuma, tāpēc daži pētnieki bieži vien uzskata, ka "sociālā inovācija vienlaikus ir par visu un par neko" (Oeij et al., 2011: 40). Tomēr zinātniskajā literatūrā var izškịirt trīs galvenās pieejas sociālās inovācijas jēdziena būtības interpretēšanai (European Communities, 2011; European Commission, 2013; Bonifacio, 2014): 
- sociālā pieprasījuma pieeja ("geto" viedoklis), kas atbilst sociālajām prasībām, kuras neapmierina tirgus vai esošās iestādes un kuras attiecas uz sabiedrības neaizsargātākajām grupām. Sociālās inovācijas procesos tiek izstrādātas jaunas pieejas, lai risinātu problēmas, kas skar jauniešus, migrantus, seniorus, bezdarbniekus u. c.;

- sabiedrības izaicinājuma pieeja ("reformistu" viedoklis), kas koncentrējas uz inovācijām sabiedrībā kopumā, integrējot sociālos, ekonomiskos un vides aspektus. Sociālās inovācijas avots ir sabiedrības izaicinājumi;

- sistēmisko pārmaiṇu pieeja (iespēju nodrošināšana), kas ir visambiciozākā un aptver iepriekšējās divas pieejas, tiek nodrošināta organizatoriskās attīstības procesā, veicinot pārmainnas attiecībās starp institūcijām un citām ieinteresētajām pusēm. Notiek sabiedrības transformācija, veidojot plašāku līdzdalības telpu, kur iespējas un mācīšanās ir labklājības avoti un rezultāti (European Communities, 2011:36-38; European Commission, 2013; Bonifacio, 2014:153-154).

Teorētiskais pētījums par sociālās inovācijas būtību sniedz priekšstatu par vairākiem savstarpēji saistītiem jēdzieniem, kas tiek minēti sociālās inovācijas definīcijās, piemēram:

- "sociālā sistēma" (McCarthy et al., 2014; Westley et al., 2014; Cajaiba-Santana, 2013),

- "sociālā vērtība" (Le Ber \& Branzei, 2010; Bonifacio, 2014; Minks, 2011),

- “sociālās vajadzības" (Heller, 2014),

- "sociālās problēmas" (Minks, 2011),

- "sociālie izaicinājumi" (The Young Foundation, 2012),

- "sociālā ietekme" (Ortega et al., 2014),

- "sociālās pārmaiṇas", "sociālā transformācija" (Dover, 2011; Cajaiba-Santana, 2013; Minks, 2011; OECD, 2010; Westley et al., 2014),

- "sistēmas main,a" (Nichols et al., 2013; OECD, 2010; Westley et al., 2014; Eiropas Ekonomikas un sociālo lietu komiteja, 2012),

- "sociālā kvalitāte" (Oeij et al., 2011; Li et al., 2012),

- "dzīves kvalitāte" (Pol \& Ville, 2009; Li et al., 2012; EdwardsSchachter et al., 2012; Bonifacio, 2014; OECD, 2010),

- "dzīves ilgums" (Pol \& Ville, 2009),

- "labklājība" (Edwards-Schachter et al., 2012; Bonifacio, 2014; Young, 2011; OECD, 2010),

- "kolektīvā/sociālā darbība" (Cajaiba-Santana, 2013; Bhatt \& Altinay, 2013),

- "sociālais kapitāls" (Bhatt \& Altinay, 2013),
Sociālās

inovācijas būtība un izaicinājumi sociālās inovācijas pētniecībā 
- "sociālā prakse" (Oeij et al., 2011; Howaldt et al., 2014; Klievink \& Janssen, 2014; Cajaiba-Santana, 2013),

- "starpnozaru partnerība” (Le Ber, Branzei, 2010; Jiménez Escobar, Morales Gutiérrez, 2011),

- "attiecības" (Jensens et al., 2012; Li et al., 2012; Klievink, Janssen, 2014; Klein et al., 2012; Nichols et al., 2013; OECD, 2010) u. c.

Daudzi pētnieki ir neapmierināti ar pašreizējo situāciju sociālās inovācijas pētījumu jomā, jo ir vajadzīga vienota un saskaṇotāka sociālās inovācijas koncepcijas izpratne (Oeij et al., 2011). Lai nodrošinātu visaptverošu priekšstatu par sociālās inovācijas fenomenu (Cajaiba-Santana, 2013) kā kompleksu, daudzdimensiju koncepciju (Edwards-Schachter et al., 2012), no konteksta atkarīgu parādību, ko spēcīgi ietekmē iesaistīto dalībnieku sociālkultūras, institucionālā un geogrāfiskā pieredze (Howaldt et al., 2014), ir nepieciešama sistēmiska izpratne par sociālās inovācijas attīstību un pētniecību. Šādai pētniecībai pārsvarā būtu jābalstās, piemēram:

- $\quad$ sistēmiskajā ekologiskajā pieejā (Nichols et al., 2013);

- sociālajā konstruktīvismā, cilvēku sajūtās un stāstos (Cajaiba-Santana, 2013);

- dizaina pieejā (Murray et al., 2010; Hillgren et al., 2011);

- līdzdalības plānojumā (Hillgren et al., 2011);

- vairāku gadījumu izpētes pieejā, interviju veikšanā, sanāksmju un pasākumu novērošanā (Dover, 2011); salīdzinošā gadījumu izpētē, veicot padzilınātas intervijas (Le Ber \& Branzei, 2010); gadījumu izpētē, veicot kvalitatīvas dal̦ēji strukturētas intervijas ar cilvēkiem, kuri ir tieši iesaistīti sociālās inovācijas procesos (Davies, 2014);

- aptaujas metodē (Bulut et al., 2013).

Fils un līdzautori (Phills et al., 2008) sociālo inovāciju definē kā jaunu, ilgtspējīgu, efektīvu sociālo problēmu risinājumu, norādot, ka tās radītā vērtība primāri dod labumu sabiedrībai kopumā, nevis konkrētiem indivīdiem, un uzsver, ka sociālā inovācija var būt gan produkts, ražošanas process vai tehnologija, gan arī ideja, princips, daḷa no tiesību akta, sociālā kustība vai vairāku minēto elementu kombinācija (piemēram, mikrokredītu kustībā ir apvienoti vairāki no iepriekš minētajiem elementiem).

Turpretī SI-DRIVE projekta, kas tiek īstenots ar ES atbalstu, partneri sociālo inovāciju definē kā jaunu sociālo praksi, ko ierosina atsevišksi indivīdi vai indivīdu apvienības, lai labāk tiktu galā ar esošajām vajadzībām un problēmām, nekā tas būtu iespējams, izmantojot tikai un vienīgi esošo praksi (Howaldt et al., 2014). SI-DRIVE projekta ietvaros veiktās literatūras izpētes rezultātā ir noteiktas piecas galvenās dimensijas sociālās inovācijas gadījumu analīzei: 
1) sociālās inovācijas kā jaunas sociālās prakses konceptuālā izpratne;

2) sabiedrības vajadzību apmierināšana un problēmu risināšana;

3) indivīdu un tīklu lomas un funkcijas sociālās inovācijas procesos inovācijas būtība un izaicinājumi sociālās inovācijas un to pārvaldībā;

4) sociālās inovācijas procesu dinamika un sociālo pārmaiṇu dinamika;

5) resursi, spējas un iespējamie ierobežojumi (Howaldt et al., 2014).

Arī Nusbaums (Nussbaum, 2003) uzskata, ka par sociālu drīkst atzìt tādu inovāciju, kuras rezultātā tiek panākta kādas indivīdam nozīmīgas pamatvajadzības nodrošināšana.

Eiropas līmenī plašu publicitāti ieguvis arī TEPSIE (Theoretical, Empirical and Policy Foundations for Social Innovation in Europe) projekts, kura īstenotājus pārstāv sešu Eiropas iestāžu pētniecības partnerība no Dānijas, Apvienotās Karalistes, Grieksijas un Vācijas. Šì projekta mērķis bija izprast teorētiskos, empīriskos un politikas pamatus sociālās inovācijas jomā Eiropā. Pamatojoties uz literatūras pārskatu un plašu iepriekš veikto pētījumu klāstu, TEPSIE piedāvā šādu sociālās inovācijas definīciju: "Sociālā inovācija ir jauni risinājumi (produkti, pakalpojumi, model̦i, tirgi, procesi utt.), kas vienlaikus atbilst sociālajai vajadzībai (efektīvāk nekā esošie risinājumi) un noved pie jaunām vai uzlabotām spējām un attiecībām, kā arī līdzekḷu un resursu lietderīgāka pielietojuma" (The Young Foundation, 2012: 18; Krlev et al., 2014: 201).

Tādējādi jāsecina, ka, pieaugot sociālās inovācijas jēdziena definīciju klāstam, aktuāla kḷūst arī nepieciešamība sistematizēt sociālās inovācijas jēdziena definīcijas (Dedijer, 1984; Zapf, 1991; Moulaert \& Nussbaumer, 2005; Pol \& Ville, 2009; Butkevičiene, 2009). Zinātniskajā literatūrā ir atrodamas vairākas sociālās inovācijas sistematizēšanas pieejas, kuras atklāj atškirīgu izpratni par to, kādi kritēriji jāizmanto, lai klasificētu sociālās inovācijas definīcijas, taču rast jēgpilnu klasifikāciju piedāvātās teorijas diskursā ir izaicinoši. Balstoties plaša teorētiskā materiāla izpētē, autori apkopojuši būtiskākos sociālās inovācijas jēdziena aspektus, kas īsumā apkopoti sistematizētās tematiskās satura grupās.

Dedijers (Dedijer, 1984) izšķir triju tipu sociālo inovāciju definīcijas, pamatojoties uz definīciju stilu:

- "kas tas ir" definīcija (piemēram, kaut kas jauns - likums, organizācija, sociālais tīkls, apmācības, vērtības, normas, lomas, uzvedības veids, iniciatīvu model̦i, uzṇēmējdarbības veids un šo elementu kombinācija);

- "kas to var veikt" definīcija (piemēram, likumdevējs, politikas izstrādātāji, uzṇēmēji, vadītāji, izglītības sektora pārstāvji, inženieri, zinātnieki); 
- " "kā to darīt" definīcija (piemēram, importēts vai radīts, nejaušība vai sistemātiskas meklēšanas rezultāts).

Zaps (Zapf, 1991) fokusējas uz sociālo inovāciju saturu; viṇš izškirir septiṇas pieejas (daḷeji tās pārklājas) sociālās inovācijas skaidrošanā, definējot sociālo inovāciju kā:

1) organizāciju vai attiecību pārstrukturizēšana;

2) jauni pakalpojumi (preces);

3) tehnoloǵijas, kas radītas, lai risinātu sociālās problēmas;

4) cilvēku iekḷaušana inovatīvos procesos;

5) lielas politiskās inovācijas;

6) preču un pakalpojumu veidu izmainnas ekonomikas struktūrā;

7) jauns dzīvesveids, kas pauž vērtības un statusu, ko var novērot caur izmainām resursu patēriñā.

Būtisku ieguldījumu sociālās inovācijas teorētiskajā izpētē devuši Dominiks Rueda (Dominik Rüede) un Katrīna Lurca (Kathrin Lurtz) (Rüede \& Lurtz, 2012). Viṇi ir analizējuši 318 zinātniskos rakstus un monogrāfijas un rezultātā konstatējuši, ka pastāv septiṇas sociālo inovāciju vienojošas pamatpazīmes:

1) dara kaut ko labu sabiedrībai,

2) maina sociālo praksi un/vai struktūru,

3) veicina vides vai sabiedrības attīstību,

4) reorganizē darba procesu,

5) piešķir tehnoloǵiskai inovācijai kultūras nozīmi un būtību,

6) veicina izmainnas sociālā darba sfērā,

7) rada jauninājumus digitālajā kontekstā.

Rezumējot virkni sociālās inovācijas definīciju, tika atklātas dažādas šìs jēdziena šksautnes, proti, sociālā inovācija ir:

- jauni likumi, organizācija vai metodes, kas rada pārmaiṇas kolektīvajās vai individuālajās attiecībās (Conger, 2009);

- jaunas sociālās prakses ieviešana noteiktā reǵionā vai sociālā kontekstā ar mērksi labāk apmierināt sabiedrības vajadzības vai risināt sociālās problēmas (Howaldt \& Jacobsen, 2010);

- jauns sociālo problēmu risinājums; tā radītā vērtība primāri dod labumu sabiedrībai kopumā, nevis atsevišksiem tās indivīdiem (Mulgan et al., 2006);

- jauns, efektīvs un ilgtspējīgs sociālo problēmu risinājums (Phills et al., 2008);

- sociālā vērtība un jaunums (newness) kā sociālais motīvs (Khutrakun, 2013). 


\section{Secinājums}

Apkopojot teorētiskās analīzes rezultātus, sociālā inovācija tiek definēta šādi: sociālā inovācija ir labāka, efektīvāka un racionālāka (salīdzinājumā ar esošajiem) aktuālo sociālo problēmu risinājumu izstrāde un ieviešana praksē, radot jaunu sadarbības kultūru un veicinot sociālo progresu sabiedrībā. Šie jaunie risinājumi varētu būt jauni produkti, pakalpojumi, model̦i, procesi, likumi, organizācija, metode, sociālo problēmu risinājumi, prakse utt., kas vienlaikus atbilst sociālajai vajadzībai un noved pie jaunām vai uzlabotām spējām un attiecībām, kā arī līdzekḷu un resursu lietderīgāka pielietojuma.
Sociālās

inovācijas būtība

un izaicinājum

sociālās inovācijas pētniecībā 


\section{SOCIĀLĀS INOVĀCIJAS}

NOZĪME SABIEDRĪBAS

ILGTSPËJIIGA ATTİSTİBĀ

\section{SVETLANA SURIKOVA, TATJANA KOK̦E, KARINE OGANISJANA}

Sociālā inovācija tiek atzīta par vienu no spēcīgākajiem sabiedrības ilgtspējīgas attīstības faktoriem (European Commission, 2012, 2013; Grimm et al., 2013; Hubert et al., 2011; Nichols et al., 2013; Phillips et al., 2015; Phills et al., 2008; Raišiene, 2012; Sanzo-Perez et al., 2015).

Pētnieki sasaista sociālās inovācijas nozīmīgumu sabiedrības attīstībā ar:

- tās atbalstu labākas nākotnes radīšanā, izstrādājot jaunas idejas dzīves kvalitātes uzlabošanai (Bonifacio, 2014; Edwards-Schachter et al., 2012; Li et al., 2012; OECD, 2010; Pol \& Ville, 2009);

- labklājības pieaugumu (Bonifacio, 2014; Edwards-Schachter et al., 2012; European Commission, 2013; Hubert et al., 2011; OECD, 2010; Sanzo-Perez et al., 2015; Young, 2011);

- sociālā kapitāla attīstību, sociālo kohēziju, iespējām un demokrātiju (Davies \& Simon, 2013a);

- $\quad$ sociālās attīstības veicināšanu (Phillips et al., 2015);

- ilgtspējīgu sociālās un ekonomiskās ietekmes sasniegšanu (Nichols et al., 2013; Jiménez Escobar \& Morales Gutiérrez, 2011; Murray et al., 2010; Ortega et al., 2014; Phillips et al., 2015);

- ilgtspējīgām sistēmiskām pārmaiñām (Hubert et al., 2011), sociālajām pārmaiṇām un sabiedrības transformāciju (Cajaiba-Santana, 2013; OECD, 2010; Westley et al., 2014);

- sociālās vērtības radīšanu (Bonifacio, 2014; Le Ber \& Branzei, 2010);

- pozitīvu pārmaiṇu radīšanu attiecībās (Jensen et al., 2012; Klein et al., 2012; Klievink \& Janssen, 2014; Li et al., 2012; Nichols et al., 2013; OECD 2010; Raišienè, 2012);

- starpnozaru partnerības attīstību (Jiménez Escobar \& Morales Gutiérrez, 2011; Le Ber \& Branzei, 2010; Sanzo-Perez et al., 2015). 
Kategoriju, kas raksturo sociālās inovācijas ietekmi uz sabiedrības attīstību, biežumi

\begin{tabular}{|c|c|c|c|c|c|c|}
\hline \multirow{3}{*}{$\begin{array}{l}\text { Nr. } \\
\text { p. k. }\end{array}$} & \multirow{3}{*}{$\begin{array}{c}\text { Sociālās } \\
\text { inovācijas } \\
\text { ietekmes } \\
\text { joma }\end{array}$} & \multirow{3}{*}{ Attīstītās kategorijas } & \multicolumn{2}{|c|}{ Demogrāfiskie kodi } & \multirow{3}{*}{$\begin{array}{l}\text { Biežumu } \\
\text { summa }\end{array}$} & \multirow{3}{*}{$\begin{array}{c}\text { Sociālās } \\
\text { inovācijas } \\
\text { ietekmes } \\
\text { jomas } \\
\text { svars }\end{array}$} \\
\hline & & & Vīrieši & Sievietes & & \\
\hline & & & \multicolumn{2}{|c|}{ Kategoriju biežumi } & & \\
\hline \multirow{4}{*}{1.} & \multirow{4}{*}{$\begin{array}{l}\text { Indivīda } \\
\text { attīstība }\end{array}$} & $\begin{array}{c}\text { Pārmaiṇas indivīda } \\
\text { attieksmē }\end{array}$ & 52 & 48 & 100 & \multirow{4}{*}{301} \\
\hline & & $\begin{array}{l}\text { Pārmaiṇas indivīda } \\
\text { domāšanā }\end{array}$ & 51 & 49 & 100 & \\
\hline & & $\begin{array}{l}\text { Pārmainas indivīda } \\
\text { veiktspējā }\end{array}$ & 42 & 38 & 80 & \\
\hline & & $\begin{array}{l}\text { Apmierinātības } \\
\text { iegūšana no } \\
\text { sasniegumiem }\end{array}$ & 12 & 9 & 21 & \\
\hline \multirow{4}{*}{2.} & \multirow{4}{*}{$\begin{array}{c}\text { Starppersonu } \\
\text { mijiedarbības } \\
\text { attīstība }\end{array}$} & $\begin{array}{c}\text { Pārmainas problēmu } \\
\text { risināšanā }\end{array}$ & 36 & 34 & 70 & \multirow{4}{*}{179} \\
\hline & & Pārmainas attiecībās & 34 & 30 & 64 & \\
\hline & & Pārmainas komunikācijā & 25 & 18 & 43 & \\
\hline & & Socializācija & 1 & 1 & 2 & \\
\hline \multirow{6}{*}{3.} & \multirow{6}{*}{$\begin{array}{l}\text { Sociālā } \\
\text { izaugsme }\end{array}$} & leguvums sabiedrībai & 22 & 19 & 41 & \multirow{6}{*}{164} \\
\hline & & $\begin{array}{c}\text { Uzlabošanās attiecīgajā } \\
\text { jomā }\end{array}$ & 28 & 25 & 53 & \\
\hline & & Jauna vērtību sistēma & 25 & 20 & 45 & \\
\hline & & Pārmainas izglītībā & 6 & 5 & 11 & \\
\hline & & Pārmaiṇas politikā & 3 & 3 & 6 & \\
\hline & & $\begin{array}{l}\text { Infrastruktūras } \\
\text { attīstība }\end{array}$ & 4 & 4 & 8 & \\
\hline \multirow{3}{*}{4.} & \multirow{3}{*}{$\begin{array}{l}\text { Inovācijas } \\
\text { attīstība }\end{array}$} & Novitāte & 15 & 14 & 29 & \multirow{3}{*}{62} \\
\hline & & $\begin{array}{l}\text { Jauni produkti un } \\
\text { pakalpojumi }\end{array}$ & 14 & 13 & 27 & \\
\hline & & Jaunas tehnoloǵijas & 4 & 2 & 6 & \\
\hline \multirow{3}{*}{5.} & \multirow{3}{*}{$\begin{array}{c}\text { Darba iespēju } \\
\text { attīstība }\end{array}$} & Karjeras izaugsme & 2 & 1 & 3 & \multirow{3}{*}{7} \\
\hline & & Jaunas darbavietas & 1 & 1 & 2 & \\
\hline & & lespēja nopelnīt & 1 & 1 & 2 & \\
\hline
\end{tabular}

Avots: Oganisjana \& Surikova, 2015: 254-255. 
Sociālā inovācija ir relatīvi jauna koncepcija Latvijā. Tāpēc arī Rīgas Tehniskajā universitātē 2015. gada 20. maijā tika apspriesti jautājumi par sociālās inovācijas būtības izpratni, piemēriem un lomu sabiedrības attīstībā; faktoriem, kas veicina vai kavē sociālās inovācijas attīstību Latvijas sabiedrībā; nosacījumiem, kas motivē valsts un nevalstiskās organizācijas, uzñēmumus un indivīdus piedalīties sociālo problēmu risināšanā; izmaiñām, kas jāveic izglītības sistēmā, lai attīstītu jauniešu gatavību un motivāciju uzsākt un īstenot sociālās inovācijas projektus. Organizētajā fokusgrupas diskusijā astoṇi uzaicinātie eksperti, kuri pārstāvēja uzñēmējdarbības, izglītības, komunikācijas, sporta un labdarības jomas, dalījās savā redzējumā par šiem jautājumiem.

Fokusgrupas diskusijas videoieraksta transkripti tika sistematizēti 13 failos, un katrs no failiem saturēja diskusijas tekstu par vienu jautājumu. Šo tekstu kvalitatīvā kontentanalīze tika veikta, izmantojot AQUAD 6 programmatūru (Huber \& Gürtler, 2004). Atvērtās kodēšanas rezultātā tika attīstītas divdesmit kategorijas (Oganisjana \& Surikova, 2015), kuras attiecas uz sociālās inovācijas nozīmi un tās ietekmi uz sabiedrības attīstību Latvijā (sk. 1. tabulu).

1. tabulā tika apkopoti visi spriedumi, kas saistīti ar sociālās inovācijas sekām, rezultātiem un ietekmi uz dažādiem procesiem, kuri notiek sabiedrībā indivīdu un sabiedrības attīstības kontekstā. Pamatojoties uz kategoriju nozīmēm, tās tika iedalītas piecās sociālās inovācijas ietekmes jomās. Pēdējā ailītē tika noteikts katras jomas svars, atbilstoši aprēḳinot katrā jomā iesaistīto kategoriju biežumu (jeb frekvenču) kopsummu.

Indivīda attīstības joma $(n=301)$. Kā redzams 1 . tabulā, visvairāk sociālā inovācija ietekmē sociālās inovācijas procesos iesaistīto indivīdu attīstību, jo sociālā inovācija stimulē pārmaiṇas indivīdu attieksmē pret procesiem, cilvēkiem un problēmām sabiedrībā, viṇu domāšanā un rīcībā, kā arī veicina apmierinātības iegūšanu no sasniegtajiem rezultātiem. Tas liecina par sociālās inovācijas nozīmīgo ietekmi uz personības izaugsmi.

Starppersonu mijiedarbības attīstības joma $(n=179)$. Kategorijas, kas iekḷautas šajā jomā, liecina, ka, piedaloties sociālās inovācijas procesos, mainās paši cilvēki un viṇu problēmu risināšanas stili; viṇi veido jaunus attiecību, komunikācijas un sadarbības veidus, tādējādi radot jaunas iespējas socializācijai.

Sociālās izaugsmes joma $(n=164)$. Kvalitatīvā kontentanalīze parādīja, ka arī fokusgrupas diskusijā uzaicinātie eksperti uzskata, ka sociālajai inovācijai ir liela ietekme uz sabiedrību kopumā, jo tā dod labumu un pilnveido dažādas jomas, izraisot pozitīvas pārmaiñas politikā un izglītībā. Tas var veicināt infrastruktūras attīstību, kas ir nepieciešama dažādu kompleksu uzdevumu izpildei. Par vienu no 
nozīmīgākajām sociālās inovācijas sekām tika atzīta jaunas vērtību sistēmas izveidošana, kas liecina par sabiedrībā notiekošām dziḷām izmainozīme sabiedrības ilgtspējīgā n,ām sociālo problēmu risināšanas gaitā.

Inovācijas attīstības joma $(n=62)$. Sociālo problēmu risināšana, kas ir sociālās inovācijas atslēgas determinante, var veicināt plašāku inovāciju attīstību, jo sociālā inovācija var novest pie dažāda veida jauninājumiem, jauniem produktiem, jauniem pakalpojumiem un jaunām tehnologijām. Tomēr šīs jomas kategorijas tika minētas retāk nekā iepriekšejo trīs jomu kategorijas, ko var saistīt ar profesionālajām nozarēm, kuras pārstāvēja fokusgrupas diskusijas dalībnieki.

Darba iespējas attīstības joma $(n=7)$. Šìs jomas kategoriju - jaunu darbavietu radīšana, iespējas nopelnīt un karjeras izaugsme - biežums nebija liels, un arī šo atziṇu var izskaidrot ar fokusgrupas diskusijas dalībnieku pārstāvēto nozaru specifiku.

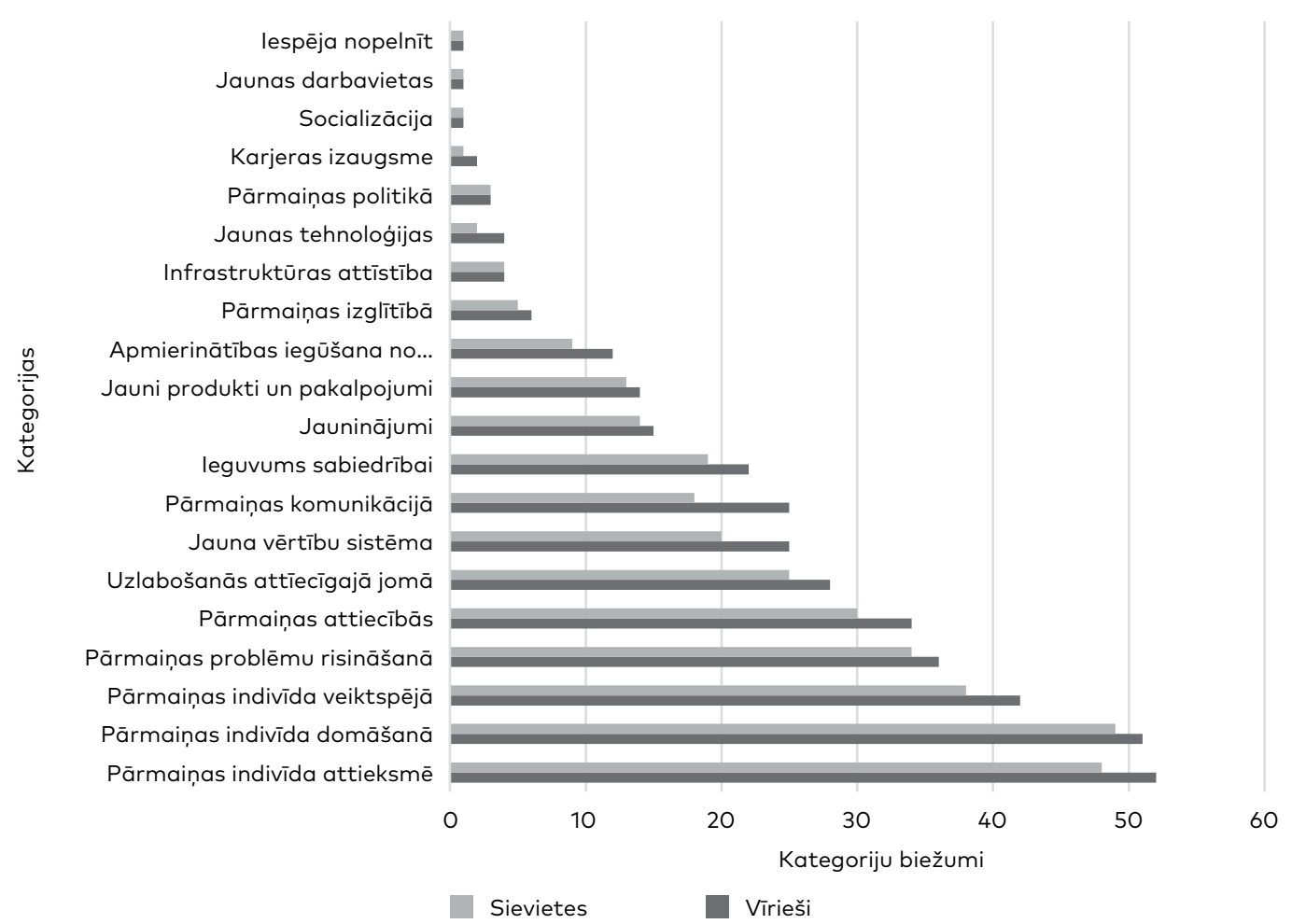

Avots: Oganisjana \& Surikova, 2015: 256.

2. attēls. Ar sociālās inovācijas ietekmi saistīto kategoriju biežumu sadalījums abu dzimumu skatījumā. 
Lai salīdzinātu abu dzimumu pārstāvju viedokḷus par sociālās inovācijas ietekmi uz sabiedrības attīstību $\left(n_{\text {vĩr. }}=4, n_{\text {siev. }}=4\right)$, uzskatāmības labad tika izveidota kategoriju biežumu sadalījuma diagramma (sk. 2. attēlu), pamatojoties uz 1 . tabulas datiem.

Kā redzams 2. attēlā, kategoriju frekvenču sadalījumu profili ir līdzīgi, kas liecina, ka abu dzimumu pārstāvji izteikušies līdzīgi saistībā ar sociālās inovācijas sekām, nozīmi un ietekmi uz sabiedrības attīstību. Tomēr vīrieši bija aktīvāki nekā sievietes, un viṇi radīja vairāk ideju saistībā ar apspriežamajiem jautājumiem.

\section{Secinājumi}

Sociālā inovācija ir nozīmīgs Latvijas sabiedrības ilgtspējīgu attīstību veicinošs elements, jo tā ierosina daudzpusīgas pozitīvas pārmaiñas dažādās dimensijās - piemēram, personības, cilvēku mijiedarbības, sabiedrības izaugsmes, inovācijas, darba iespējas, cilvēku dzīves kvalitātes un dzīvesveida uzlabošanas. Turklāt sociālās inovācijas procesos iesaistītie indivīdi un sabiedrība kopumā iegūst, jo:

- piedaloties sociālās inovācijas procesos, notiek pozitīvas pārmain,as cilvēka domāšanā, veiktspējā un attieksmē pret citiem cilvēkiem un problēmām sabiedrībā;

- sociālā inovācija uzlabo sadarbības kvalitāti, kas tiek panākta, pilnveidojot sociālo problēmu risināšanas paṇēmienus, uzlabojot komunikāciju un starppersonu attiecības, stimulējot socializācijas iespējas;

- sociālā inovācija veido bāzi sociālajai izaugsmei, jo nodrošina ieguvumus visai sabiedrībai kopumā, attīsta sociālo infrastruktūru, izraisa pozitīvas pārmaingas izglītībā, politikā un citās jomās, kā arī attīsta jaunas, uz cilvēku centrētas vērtību sistēmas veidošanos sabiedrībā;

- sociālās inovācijas rezultātā var tikt radītas jaunas tehnoloǵijas, produkti un pakalpojumi; tātad sociālā inovācija var veicināt inovāciju vispār;

- sociālā inovācija var veicināt karjeras izaugsmi un jaunu darbavietu radīšanu. 


\section{SOCIĀLO INOVĀCIJU \\ IETEKMÉJOŠIE FAKTORI}

\section{KARINE OGANISJANA, SVETLANA SURIKOVA, TĀLIS LAIZĀNS}

Pētnieki sociālo inovāciju veicinošos un kavējošos faktorus dēvē dažādi: dzinēji (drivers) un šksēršlı (barriers) (Bund et al., 2013; Chalmers, 2012; Howaldt et al., 2014; Mendes et al., 2012), pievelkošie faktori ( $p$ ullfactors) un atgrūdošie faktori (push-factors) (Antadze \& Westley, 2010; Bund et al., 2013; Mulgan et al., 2007a), nodrošinošie faktori (enabling factors) un atspējošie/traucējošie faktori (disabling/hindering factors) (Bund et al., 2013; Hubert et al., 2011).

\subsection{Pētījumi par sociālo inovāciju ietekmējošajiem faktoriem}

Sociālās inovācijas procesi ir sarežgiìti, jo tos nosaka sociālo, kultūras, ekonomisko un politisko faktoru mijiedarbība. Šì daudzfaktoru ietekme rada dažādus šķēršlı sus sociālās inovācijas projektu realizācijai, jo lielākā dala sociālo problēmu ir sarežgìtas un daudzpusīgas. No otras puses, šo faktoru kombinācija var kḷūt par labvēlīgu spēku, kas spēj virzìt sociālās inovācijas procesus.

Literatūras analīze rāda, ka sociālās inovācijas procesus ietekmē virkne faktoru, kuri tiek klasificēti dažādos veidos:

- politiskie, sociālie, ekonomiskie un kultūras faktori (Antadze \& Westley, 2010);

- sociālais klimats, resursi, institucionālie un politiskie faktori (Bund et al., 2013);

- ārējie un iekšējie faktori (Antadze \& Westley, 2010);

- strukturālie un aǵentūras faktori (Mendes et al., 2012).

Starp šiem faktoriem pastāv savstarpēja atkarība, ietekme un iedarbība (Antadze \& Westley, 2010; Bund et al., 2013; Howaldt et al., 2014; Mendes et al., 2012). Katrā sociālajā vidē šo faktoru kombinācija un mijiedarbība veidojas specifiski, kas var kavēt vai veicināt sociālo inovāciju. 
Bands un kolēgi (Bund et al., 2013) ir konceptualizējuši četras sociālo inovāciju nodrošinošo nosacījumu grupas - (1) resursu, (2) institucionālo, (3) politisko un (4) sociālā klimata -, kas ḷauj īstenot sociālās inovācijas procesus. Šie nosacījumi rada piemērotu vidi, jo stimulē aktīvu piedalīšanos inovācijas procesos, kā arī palīdz izstrādāt aktuālo problēmu risinājumus, mobilizē nepieciešamos resursus un gatavību uzṇemties risku, lai īstenotu idejas praksē un sasniegtu uzstādīto mērḳi. Tā kā šìs četras grupas veido labvēlīgus nosacījumus sociālās inovācijas îstenošanai, to elementi varētu tikt apskatīti kā sociālo inovāciju veicinošie faktori (sk. 2. tabulu).

Tikai ar visu šo faktoru kombināciju var tikt mobilizēti resursi sociālās inovācijas procesu veicināšanai. Katra ar faktoriem saistīto nosacījumu neesamība, nepietiekama attīstība vai trūkums var radīt škēešslus sociālajai inovācijai. Piemēram, faktora "Pilsoṇu atvērtība jauninājumiem un riska uzn,emšanai" (sk. 2. tabulu) neesamība var izraisīt nopietnus apgrūtinājumus sociālās inovācijas procesam. Virkne pētījumu liecina, ka sociālās inovācijas škēēšlıiem ir psihosociāla daba, proti, daudziem cilvēkiem ir bail eksperimentēt un ir grūti piennemt neveiksmes, taču tās var izmantot un uztvert kā iespēju mācīties. Šādi cilvēki nav atvērti jaunai pieredzei, un tie parasti neuzn,emas risku; tas savukārt kavē sociālo inovāciju (Brown \& Wyatt, 2010). Šajā sakarā tiek apgalvots, ka "mācīšanās kultūras veicināšana un sociālās inovācijas infrastruktūras attīstība nav viegls uzdevums. Tas ietver domāšanas un prakses mainu un riska uzṇemšanos arī valsts sektorā, kas prasa nepārtrauktu savstarpēju mācīšanos" (Hubert et al., 2011: 95).

Par vienu no sociālās inovācijas nopietniem šksēršliem tiek uzskatīts atbilstošu sadarbības tīklu trūkums (Mulgan et al., 2007b; Caulier-Grice et al., 2010; Chalmerss, 2012; More \& Westley, 2011). Arī "brīvprātīgs darbs" ir sociālo inovāciju veicinošs faktors (sk. 2. tabulu), taču ne vienmēr sociālā inovācija var būt vēlama vai šksist pietiekami noderīga (Mulgan, 2006), un tas var izraisīt nevēlēšanos strādāt brīvprātīgi. "Politiskā stabilitāte un demokrātija" ir sociālo inovāciju veicinošs faktors (sk. 2. tabulu), un pretēji - cieša varas monopolizācija sabiedrībā un brīvas saziṇas kavēšana apgrūtina sociālo inovāciju (Mulgan, 2006).

TEPSIE projekta partneri sociālās inovācijas kavējošos faktorus sistematizē divās grupās:

- $\quad$ strukturālie šḳēršlı, kas ietver sevī tādus faktorus, kuri rodas no sociālajiem, politiskajiem, ekonomiskajiem, tehnologiskajiem u. c. apstākḷiem, kuros darbojas sociālie inovatori;

- agentūras šḳēršlı, kas ietver sevī tos kavējošos faktorus, kurus nosaka sociālās inovācijas procesos iesaistītu indivīdu vai organizāciju īpatnības un darbības (Mendes et al., 2012). Sociālo inovāciju kavējošos faktorus var sistematizēt kā iekšējos un 
- $\quad$ prāts (Brown \& Wyatt, 2010; Miller, 2010; Mulgan et al., 2007b);

- nepietiekami attīstītas prasmes (Koch \& Hauknes, 2005; Mulgan \& Albury, 2003);

2. tabula

Sociālo inovāciju nodrošinošie faktori, kurus nosaka resursi, institucionālais, politiskais un sociālā klimata ietvars

\begin{tabular}{|c|c|}
\hline $\begin{array}{c}\text { Sociālo inovāciju nodrošinošie faktori, kurus } \\
\text { nosaka resursu pieejamība }\end{array}$ & $\begin{array}{c}\text { Sociālo inovāciju nodrošinošie faktori, kurus } \\
\text { nosaka institucionālais ietvars }\end{array}$ \\
\hline $\begin{array}{l}\text { Sociālajiem mērḳiem paredzētie finanšu resursi } \\
\text { - } \quad \text { Sociālajai ekonomikai pieejamā finansējuma } \\
\text { nevienmērīgums } \\
\text { - Valsts sociālie izdevumi } \\
\text { - } \quad \text { Privātais finansējums } \\
\text { Cilvēkresursi } \\
\text { - } \quad \text { Brīvprātīgs darbs } \\
\text { - } \quad \text { Profesionālizācija / radošu pieeju } \\
\text { atbalstošās darbavietas sociālajā jomā } \\
\text { Infrastruktūras resursi } \\
\text { - } \quad \text { Akadēmiskie resursi, kas tiek iesaistīti } \\
\text { - sociālajā inovācijā } \\
\text { - Sociālās inovācijas sadarbības tīkli } \\
\text { IKT un vispārējā infrastruktūra (kā } \\
\text { priekšnosacījums sociālās inovācijas } \\
\text { nodrošināšanai) }\end{array}$ & $\begin{array}{l}\text { Normatīvie standarti } \\
\text { - Tolerance } \\
\text { - Dzimumu līdztiesība } \\
\text { - Solidaritāte } \\
\text { - Vides ilgstspējība } \\
\text { Normatīvie un regulējošie standarti } \\
\text { - Sociālo organizāciju tiesiskā bāze } \\
\text { - Sociālās apdrošināšanas tiesiskā bāze } \\
\text { - Normatīvās bāzes risinājumi sociālās } \\
\text { inovācijas jomā } \\
\text { - Publisko iepirkumu regulējošie normatīvie } \\
\text { akti } \\
\text { Kultūrizglītības iestādes } \\
\text { - Cilvēktiesības }\end{array}$ \\
\hline $\begin{array}{c}\text { Sociālo inovāciju nodrošinošie faktori, kurus } \\
\text { nosaka politiskais ietvars }\end{array}$ & $\begin{array}{l}\text { Sociālo inovāciju nodrošinošie faktori, kurus } \\
\text { nosaka sociālais klimats }\end{array}$ \\
\hline $\begin{array}{l}\text { Politikas izpratne } \\
\text { - Politikas veidotāju izpratne par sociālo } \\
\text { inovāciju } \\
\text { - Politikas veidotāju izpratne par sociālajām } \\
\text { vajadzībām } \\
\text { Politiskā vide } \\
\text { - Politiskā stabilitāte un demokrātija } \\
\text { - Valdības efektivitāte } \\
\text { - Caurspīdīgums (atklātība) } \\
\text { - Likumdošana } \\
\text { - } \\
\text { Preses brīvība }\end{array}$ & $\begin{array}{l}\text { Pieprasījums pēc sociālās inovācijas } \\
\text { - } \quad \text { Atsaucība līdzdalīties sociālo vajadzību } \\
\text { nodrošināšanā } \\
\text { - } \quad \text { Nepieciešamība pēc izmaiṇām } \\
\text { Sociālā iesaistī̌̌anās un attieksme } \\
\text { - Politiskā līdzdalība } \\
\text { - } \quad \text { Dalība pilsoniskās sabiedrības organizācijās } \\
\text { - Pilsoṇu attieksme pret uzṇēmējdarbību } \\
\text { - Pilsoṇu atvērtība jauninājumiem un } \\
\text { gatavība riskēt }\end{array}$ \\
\hline
\end{tabular}

Avots: veidoja autores, pamatojoties uz Bund et al., 2013: 42-45. 
- neuzticēšanās inovatoriem jeb jaunu ideju un risinājumu piedāvātājiem (van der Geest \& Heuts, 2008);

- pretestība pārmain̄ām (Koch \& Hauknes, 2005; van der Geest \& Heuts, 2008) u. c.

Ārējie sociālās inovācijas šḳēršḷi ir saistīti ar sarežǵītākiem izaicinājumiem, piemēram:

- nepietiekami naudas līdzekḷi un finansējuma iespējas (CaulierGrice et al., 2010; Hubert et al., 2011; Koch \& Hauknes, 2005; Mulgan, 2006);

- pārāk daudz birokrātisku noteikumu, spiedienu un administratīvo slogu (Clark et al., 2008; Chapman, 2004; Koch \& Hauknes, 2005; Mulgan, 2007; Mulgan \& Albury, 2003);

- priekšroka birokratizētām vadības un kontroles formām (Chapman, 2004);

- "augstas sienas", kas sadala departamentus, aǵentūras un profesijas vai saistītus pakalpojumus (Mulgan, 2007);

- organizāciju mācīšanās spēju trūkums visos līmen,os (Clark et al., 2008; Koch \& Hauknes, 2005) u. c.

\subsection{Sociālo inovāciju ietekmējošie faktori Latvijā}

Empīriskie dati tika iegūti fokusgrupas diskusijā (sk. 2. nodaļu), sagatavojot videoierakstu transkriptus par sociālo inovāciju veicinošiem un kavējošiem faktoriem. Kategorijas, kuras tika attīstītas kvalitatīvajā kontentanalīzē, parādījās pāros, turklāt katrs pāris sastāvēja no pretējas nozīmes kategorijām, piemēram, "Radošā domāšana" un "Radošās domāšanas trūkums", "Pasivitāte" un "Aktīva dzīves pozīcija" utt. (sk. 3. tabulu).

Šādi pāri varētu rasties loǵiski, jo šīs kategorijas raksturo divas pretējas parādības - veicināšanu vai kavēšanos -, kas savukārt ir ietekmes divas pretējas puses.

Kā šīs kategorijas tika attīstītas, tiks ilustrēts ar dažiem videoieraksta transkriptu tekstu fragmentu kodēšanas piemēriem.

- “1993. gadā nodibinājām sporta federāciju. Ilgi nācās dzirdēt jautājumus un argumentus par to, ka bērns invalīds un sports ir divas nesavienojamas lietas - invalīdi skolā pat nenodarbojas ar sportu! Šie cilvēki nevar atbrīvoties no stereotipiem!” (Radošās domāšanas trūkums.)

- Vēl viens konservatīvās domāšanas piemērs tika dots saistībā ar mēginājumiem izglītot skolas bērnus par paraolimpiskajiem sporta veidiem. "Es vienmēr dzirdu dažādus argumentus pret. Daži vecāki ir aizspriedumaini un pat neḷauj saviem veselajiem 
bērniem pasēdēt ratinnkrēslos, lai sajustu, kā ir būt invalīdam un kā invalīdi var piedalīties sporta spēlēs. (Radošās domāšanas

trūkums, Atvērtības trūkums jaunai pieredzei.) Jaunieši ir vairāk atvērti domājoši." (Radošā domāšana, Atvērtība jaunai pieredzei.) Tātad bieži vien vecākiem piemīt kvalitātes, kuras kavē sociālo inovāciju, bet jauniešiem - otrādi.

- Faktori "Konservatīvā domāšana" un "Atvērtības trūkums jaunai pieredzei" un novitātei kā sociālo inovāciju kavējošie faktori tika norādīti dažādos kontekstos: "G̣imenes ārsti joprojām raksta diagnozi un receptes manuāli ar tik sliktu rokrakstu, ka dažkārt nav iespējams izlasīt, kas rakstīts uz papīra. Grūti likt viniem izmantot tehnologijas." (Radošās domāšanas trūkums, Atvērtības trūkums jaunai pieredzei.)

- Tajā pašā laikā fokusgrupas diskusijas dalībnieki runāja arī par dažādiem jauninājumiem sociālajās attiecībās Latvijā. Viens no tiem attiecas uz skolu, uzṇēmumu un banku sadarbību: "Uzṇēmumu un banku pārstāvji regulāri nāk uz skolām un informē skolas direktorus par viṇu darbu. Skolu vadība apgalvo, ka tas

3. tabula

Sociālo inovāciju veicinošajiem un kavējošajiem faktoriem atbilstošo kategoriju biežumi

\begin{tabular}{|c|c|c|c|c|}
\hline $\begin{array}{l}\text { Nr. } \\
\text { p. k. }\end{array}$ & $\begin{array}{c}\text { Sociālo inovāciju veicinošie } \\
\text { faktori }\end{array}$ & $\begin{array}{l}\text { Kategoriju } \\
\text { biežumi }\end{array}$ & $\begin{array}{c}\text { Sociālo inovāciju kavējošie } \\
\text { faktori }\end{array}$ & $\begin{array}{l}\text { Kategoriju } \\
\text { biežumi }\end{array}$ \\
\hline 1. & Atvērtība jaunai pieredzei & 76 & $\begin{array}{l}\text { Atvērtības trūkums jaunai } \\
\text { pieredzei }\end{array}$ & 30 \\
\hline 2. & Proaktīvā domāšana & 62 & $\begin{array}{l}\text { Proaktīvās domāšanas } \\
\text { trūkums }\end{array}$ & 14 \\
\hline 3. & Sociālā apziṇa & 36 & Sociālās apziṇas trūkums & 5 \\
\hline 4. & Atbildība & 33 & Atbildības trūkums & 7 \\
\hline 5. & lesaistīšanās mūžizglītībā & 28 & $\begin{array}{l}\text { Neiesaistīšanās } \\
\text { mūžizglītībā }\end{array}$ & 4 \\
\hline 6. & Aktīva dzīves pozīcija & 25 & Pasivitāte & 43 \\
\hline 7. & Pozitīvā pieredze & 10 & Pozitīvās pieredzes trūkums & 8 \\
\hline 8. & Radošā domāšana & 6 & $\begin{array}{l}\text { Radošās domāšanas } \\
\text { trūkums }\end{array}$ & 18 \\
\hline 9. & Maza varas distance & 9 & Liela varas distance & 13 \\
\hline 10. & Birokrātisko šḳēršlu neesamība & 5 & Birokrātiskie šḳērṣ̌i & 8 \\
\hline
\end{tabular}

Avots: Oganisjana, Surikova \& Laizāns, 2015: 190. 
iedvesmo viṇus, jo viṇi redz, cik lietderīga ir šì sadarbība darba organizēšanai skolā. (Atvērtība jaunai pieredzei, Pozitīvā pieredze.) Šāda sadarbība paplašina skolotāju un iestāžu perspektīvas, jo sanāksmes ar dažādu profesiju veiksmīgiem cilvēkiem veicina sociālo inovāciju, radošumu un jauninājumus skolās. Tas ir īpaši svarīgi, jo skolas vide dažkārt ir pārāk ierobežota; skolas darbinieki kontaktējas galvenokārt ar kolēgiem no kaimiṇskolām." (Proaktīvā domāšana, Pozitīvā pieredze, Piedalīšanās mūžizglītībā, Radošā domāšana.)

- Runājot par dažādām sociālās inovācijas kampañām, viens no fokusgrupas diskusijas dalībniekiem teica: "Lielā talka" ir fantastiska iniciatīva, kas vieno pilsētas, ciematus un organizācijas visā Latvijā. (Sociālā apziṇa, Atbildība, Proaktīvā domāšana.) Jā, mēs ejam uz "Lielo talku", jo tā ir stilīgi un tā ir plaši redzama televīzijā; pat prezidents tur iet. (Aktīvā dzīves pozīcija.) Tajā pašā laikā, ko mēs tur darām? Mēs dzeram kafiju no plastmasas krūzītēm, metam darba cimdus kaut kur uz zemes vai maisos; tādējādi mēs radām papildu atkritumus!" (Sociālās apziṇas trūkums, Proaktīvās domāšanas trūkums, Atbildības trūkums.) Tātad vienā sabiedrības dzīves situācijā savā starpā kopā ir savijušies sociālo inovāciju veicinošie un kavējošie faktori.

- Kad bija runa par birokrātiskajiem šḳēršliem kā sociālo inovāciju kavējošiem faktoriem valsts organizācijās, fokusgrupas diskusijas dalībnieku viedokḷi sadalījās divās pretējās grupās: "Uzṇēmēji bieži saskaras ar grūtībām, jo pastāv stingra noteikumu ievērošana un pārāk daudz formalitāšu dažādās organizācijās, kas uzṇēmējiem traucē attīstīt savus uzṇēmumus. (Birokrātiskie šḳēršli.) No otras puses, bija arī pozitīva pieredze: "Esmu patīkami pārsteigta par to, cik atvērti mūsu cilvēki ir sadarbībai! Vienā no Rīgas izpilddirekcijām, kur mēs devāmies runāt par festivālu, kuru gatavojamies organizēt Lucavsalā, izrādīja patiesu interesi par festivāla ideju, uzdeva dažus jautājumus un deva reālu atbalstu." (Birokrātisko šḳēršḷ neesamība, Atvērtība jaunai pieredzei, Pozitīvā pieredze.) Vai arī: "Mūsu pašvaldība strādā perfekti. Kad mums ir jāpieṇem lēmums, mēs vienmēr varam sagaidìt atbalstu no domes, jo divu stundu laikā var tikt organizēta speciāla sapulce un var tikt parakstīti atbilstoši dokumenti." (Birokrātisko šḳēršlu neesamība, Maza varas distance.)

- Tomēr šajā sakarā bija arī skeptiski viedokḷi: "Nedomāju tik pozitīvi par valsts organizācijām, kaut gan, kad es eju pie viṇiem 
tagad, viṇi ir tik pieklājīgi un uzmanīgi. Bet pirms pieciem gadiem, kad mēs vēl nebijām labi pazīstami, situācija nebija šāda. Daži ietekmējošie mani draugi joprojām apgalvo, ka viṇi nevar nokḷūt pie atbildīgajām iestādēm, kamēr viṇi neiegūs kādas spēcīgas kontaktpersonas." (Liela varas distance.)

3. tabula tika izveidota, analizējot visus fokusgrupas diskusijas videoierakstu transkriptu tekstus, kur bija runa par sociālo inovāciju veicinošajiem un kavējošajiem faktoriem. Kā jau minēts šīs nodaḷas sākumā, gan veicināšana, gan kavēšana ir divas pretējas ietekmes puses. Tāpēc arī 3. attēlā sociālo inovāciju ietekmējošie faktori ir parādīti pāros: tumši pelēkā krāsā faktori, kas veicina sociālo inovāciju, un gaiši pelēkā krāsā faktori, kas to kavē.

Diagrammā uz horizontālās ass dots katram faktoram atbilstošās kategorijas biežums, kas parāda faktora svaru. Piemēram, par kategoriju "Atvērtība jaunai pieredzei" tika runāts visvairāk reižu ( $n=76)$, kas nozīmē, ka fokusgrupas diskusijas dalībnieki atzīmēja šo faktoru kā visnozīmīgāko sociālās inovācijas veicināšanā Latvijā.

Secinājumi tika izdarīti, apkopojot šajā nodaḷā veiktā teorētiskā pētījuma rezultātus un šìs diagrammas analīzi (sk. 3. attēlu).

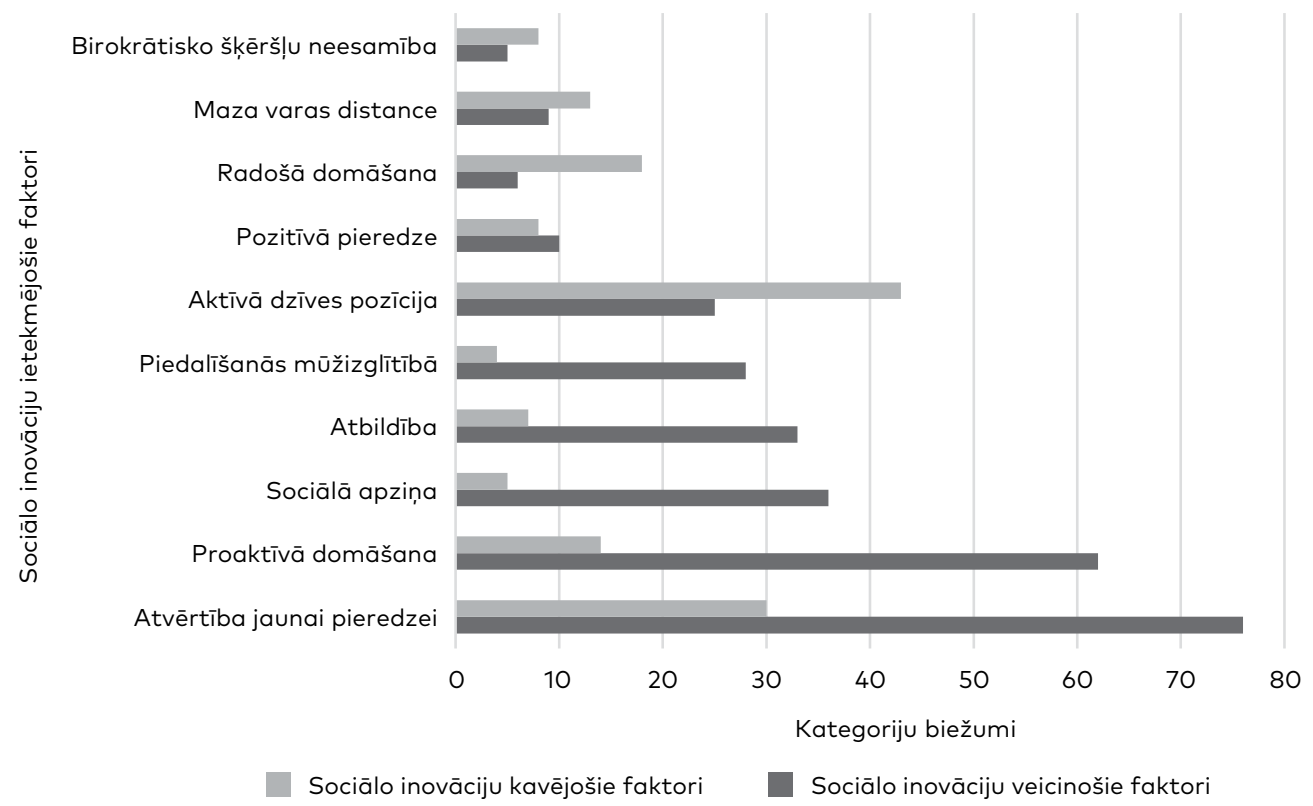

Avots: Oganisjana, Surikova \& Laizāns, 2015: 194.

3. attēls. Sociālo inovāciju ietekmējošo faktoru biežumu sadalījums. 


\section{Secinājumi}

Pētījumā atklājās sociālo inovāciju ietekmējošo faktoru duālā daba, proti, atkarībā no faktora esamības vai tam atbilstošo nosacījumu un specifisku raksturīgu elementu nozīmīguma un konteksta tas var vai nu veicināt, vai kavēt sociālās inovācijas procesus.

- Atvērtība jaunai pieredzei un neizvairīšanās no nezināmām situācijām, proaktīvā domāšana sabiedrības problēmu saskatīšanā un to risināšanas procesā, sociālā apziṇa un atbildība, gatavība iesaistīties mūžizglītībā un pilnveidot zināšanas un prasmes, kas nepieciešamas dažādu problēmu risināšanā, aktīvā dzīves pozīcija, pozitīvā pieredze sociālo problēmu veiksmīgā risināšanā, radošā domāšana, kas ir brīva no stereotipiem, maza varas distance un birokrātisko šksēršlu neesamība ir sociālo inovāciju veicinošie, tas ir, pozitīvi ietekmējošie faktori.

- Un otrādi, atvērtības trūkums jaunai pieredzei un izvairīšanās no nenoteiktām situācijām un citu cilvēku pieredzes, proaktīvās domāšanas trūkums, vāji attīstīta sociālā apziṇa, atbildības trūkums, nevēlēšanās iesaistīties mūžizglītībā, lai pilnveidotu savas zināšanas un prasmes problēmu risināšanā, pasivitāte un pozitīvās pieredzes trūkums sociālo problēmu risināšanā, radošās domāšanas trūkums un stereotipiska dzīves uztvere, varas distance un birokrātiskie šķēršlıi ir sociālo inovāciju kavējošie, tas ir, negatīvi ietekmējošie faktori.

- Fokusgrupas diskusijas dalībnieki uzskata, ka sociālo inovāciju ietekmējošie faktori Latvijā ir galvenokārt saistīti ar indivīdu vai indivīdu grupu īpašībām, domāšanas veidu, dzīves pozīciju, kompetencēm un pieredzi (sk. 3.tabulā pirmos astoṇus faktorus no desmit faktoriem): atvērtība jaunai pieredzei, atbildība, proaktīvā domāšana, radošā domāšana, sociālā apzin,a, iesaistīšanās mūžizglītībā, pozitīvā pieredze, aktīvā dzīves pozīcija. Tikai divi sociālo inovāciju ietekmējošie faktori - varas distance un birokrātiskie šksēršlı - ir ārēji attiecībā pret indivīdu vai indivīdu grupu. Tas nozīmē, ka sociālās inovācijas veicināšanai sevišķa uzmanība jāpievērš cilvēku personības, kompetenču un pasaules un dzīves skatījuma pilnveidošanai.

- Visbiežāk kā sociālo inovāciju veicinošie faktori Latvijā bija minēti "Atvērtība jaunai pieredzei" $(n=76)$, "Proaktīvā domāšana" $(n=62)$, "Sociālā apziṇa" $(n=36)$ un "Atbildība" $(n=33)$. Turpretī kā sociālo inovāciju kavējošie faktori Latvijā bija uzsvērti "Pasivitāte" ( $n=43)$, "Atvērtības trūkums jaunai pieredzei" $(n=30)$ un "Konservatīvā domāšana" ( $n=18)$ (sk. 3. tabulu). 
Šai pētījuma daḷai bija sagatavošanas raksturs, kuras mērḳis bija Sociālo inovāciju ietekmējošie uzzināt, kāds ir dažādu Latvijas sabiedrības nozaru (uzṇēmējdarbība, izglītība, komunikācija, sports un labdarība) pārstāvju viedoklis par sociālo inovāciju kavējošiem un veicinošiem faktoriem. Rezultāti ilustrē šo jautājumu izpratni Latvijā. Iegūtās atziṇas veidoja platformu, lai izstrādātu un uzsāktu plašāku pētījumu par sociālās inovācijas projektiem, lai varētu ne tikai noteikt škēēšlus, bet arī izvērtēt to pārvarēšanas mehānismus un līdzekḷus. Tas ir analizēts nākamajā, 4. nodaḷā. 


\section{SOCIĀLĀS INOVĀCIJAS}

ŠK়ËRŠLII UN TO PĀRVARĒŠANAS

LITDZEKL̦I UN MEHĀNISMI

LATVIJĀ

KARINE OGANISJANA, YULIYA EREMINA,

SALOME GVATUA, BENJAMIN NGONGO KABWENDE, OZOEMENA JOSEPH CHUKWU

\subsection{Pētījuma īstenošanas konteksts}

VPP "EKOSOC-LV" 5.2.7. projekta pētījuma nobeiguma fāzē 2016. akadēmiskā gada pavasara semestrī Rīgas Tehniskās universitātes Inženierekonomikas un vadības fakultātes ārzemju un Latvijas maǵistrantiem tika piedāvāta iespēja piedalīties šajā pētījumā Karine Oganisjanas vadītā studiju kursa "Mūsdienu pētījumu metodes: teorija un prakse" ietvaros. Šāds lēmums tika piennemts ar mērḳi integrēt studiju procesu reālajā pētniecībā un parādīt pašiem studentiem, kā vinu intelektuālais potenciāls varētu būt jēgpilni izmantots pētījumos valsts līmenī. Studenti tika iesaistīti reāla pētījuma visos posmos - datu vākšanā, analīzē, rezultātu interpretēšanā, kā arī atskaites par paveikto pētījumu sagatavošanā. Tātad maǵistranti varēja ne tikai mācīties pētnieciskās metodes un metodologiju studiju kursā, bet arī veikt reālu pētījumu Latvijas Republikas Valsts pētījumu programmas ietvaros. Par šādas pieejas pamatotību un vērtību augstskolu studentu pētniecisko kompetenču veicināšanā un studiju praktiskās jēgas paaugstināšanā projekta komanda jau bija iepriekš veikusi pētījumu, pamatojoties uz K. Oganisjanas 2015. akadēmiskā gada rudens semestra darbu ar ārzemju maǵistrantiem, veicot starptautisko pētījumu par sociālu problēmu risināšanas pieredzi pasaulē (Oganisjana et al., 2017a).

Pētijuma ticamības un validitātes nodrošināšanai 2016. akadēmiskā gada studentiem tika piedāvāts izveidot komandas intervijās iegūto 
kvalitatīvo un kvantitatīvo datu analīzes veikšanai un rezultātu integrēšanai. Labākie rezultāti bija četru studentu komandai: Yuliya Eremina (Uzbekistāna), Salome Gvatua (Gruzija), Benjamin Ngongo Kabwende (Kongo) un Ozoemena Joseph Chukwu (Nigērija). Tieši šai komandai tika piedāvāta iespēja uzrakstīt zinātnisko rakstu "Barriers to Social Innovation and Ways of Overcoming them in Latvia" K. Oganisjanas vadībā un prezentēt to Pasaules daudznozaru konferencē "The $21^{\text {st }}$ World Multi-Conference on Systemics, Cybernetics and Informatics: WMSCI 2017" Orlando, Florida, ASV, 08.07.-11.07.2017. Zinātniskais raksts tika apbalvots ar "Session's best paper's award" un publicēts žurnālā "Journal on Systemics, Cybernetics and Informatics" (Oganisjana et al., 2017b).

Sociālās inovācijas šḳēršlu teorētiskā bāze tika analizēta iepriekšējā nodal̦ā.

Sociālo inovāciju šksēršlı pārvarēšanas mehānismu izpratne joprojām ir liels izaicinājums, jo paši šksēršl li var būt l̦oti specifiski dažādu veidu organizācijās, nozarēs vai reǵionos. Tāpēc arī mehānismi un pasākumi, kas tiek veikti, lai pārvarētu šos šksēršl̦us, ir atšksirīgi, un tiem ir dažāds politiskais, finansiālais un organizatoriskais raksturs. Tomēr šie mehānismi var tikt piemēroti lielākajai daḷai sociālās inovācijas projektu kopumā, neskatoties uz situāciju īpatnībām.

Sociālās inovācijas šḳēršlu pārvarēšanai Eiropā tika izstrādātas un pieṇemtas vairākas politiskas programmas, kuras sevī iekḷauj:

- jauna tiesiskā ietvara izveidi;

- finansiālā atbalsta sniegšanu projektiem, programmām un institūcijām;

- inovāciju atbalstošu finanšu instrumentu izstrādi;

- sociālās inovācijas iestāžu dibināšanu;

- sadarbības uzlabošanu un jauninājumu izstrādāšanas rīku ieviešanu (European Union \& The Young Foundation, 2010).

Eiropas Savienības dienests "European Citizen Action Service" piedāvā sociālās inovācijas škēeršlu pārvarēšanas iespējas divos līmeṇos:

1) Eiropas Savienības līmenī:

- pieñemot tādu budžeta struktūru, kas stimulētu un atbalstītu sociālo inovāciju;

- veicinot dalībvalstu diskusijas par sociālo inovāciju un riskiem, kas saistīti ar tās īstenošanu;

- atvieglojot piekḷuvi finansējumam sociālajiem uzṇēmējiem un pilsoniskajai sabiedrībai;

- adaptējot inovatīvas rezultātu novērtēšanas sistēmas, lai analizētu sociālās inovācijas ietekmi;

2) valsts lìmenī:

- atvieglojot piekluvi finansējumam sociālajiem uzṇēmējiem un pilsoniskajai sabiedrībai;
Karine Oganisjana, 
- veicinot tīklu un to pārvaldes sistēmas izveidi;

- paaugstinot informētību (Mariani, 2011).

Politikas instrumentu uzlabošana, izpratne par sociālās inovācijas jautājumiem, statistiskās informācijas sniegšana un sociālās inovācijas izpēte ir atzìtas par svarīgiem pasākumiem, ar kuru palīdzību var pārvarēt sociālās inovācijas šksēršlus ar nosacījumu, ka:

a) tiek izvirzìtas problēmas un tiek pētītas iespējas,

b) tiek izstrādāti un īstenoti šḳēršlı pārvarēšanas pasākumi,

c) projekti ir noturīgi mikro-, mezo- un makrolīmenī (Frias et al., 2013).

Līdztekus politiskiem, finansiāliem un organizatoriskiem līdzekliem sociālās inovācijas šḳēršlu pārvarēšanā nozīmīga loma pieder izglītībai, jo tā (1) izvirza problēmas risināšanai, (2) attīsta cilvēkresursus, kam jāīsteno sociālā inovācija, (3) identificē jaunas iespējas un perspektīvas (Surikova, Oganisjana \& Grīnberga-Zālīte, 2015). Izglītība var palīdzēt pārvarēt sabiedrības atvērtības trūkumu jauninājumiem, pilnveidot nepietiekami attīstītu apziṇu un atbildības izjūtu, veicināt kreatīvo un proaktīvo domāšanu, pārvarēt pasivitāti un tos indivīdam raksturīgos iekšējos faktorus, kuri kavē sociālās inovācijas procesu sabiedrībā (Počs et al., 2018).

Šis pētījums ne tikai analizē šksēršlıus, ar kuriem saskaras sociālās inovācijas projekti Latvijā, un to pārvarēšanas veidus kopumā, bet arī nodrošina "šḳēršlı - to pārvarēšanas līdzekḷ,i un mehānismi" analīzi, lai sniegtu arī ieskatu par līdzekḷiem un mehānismiem, kuri tiek pielietoti katra atsevišksa šksēršlı pārvarēšanai.

\subsection{Pētījuma organizācija}

Datu vākšana tika organizēta gan klātienes un Skype intervijās, gan arī elektroniskā formātā. Prakse parādīja, ka atsaucības līmenis un kvalitāte elektronisko anketu aizpildīšanai nebija l̦oti augsti, neskatoties uz to, ka pētījumu grupai bija provizoriska saruna pa telefonu ar sociālo inovāciju projektu pārstāvjiem, lai izskaidrotu intervijas būtību un atsevišḱas detalıas. Tādēl tika lemts izmantot "Crowdfunding” principu, tas ir, pētījuma komandas un studentu centienus kopīgas datu bāzes izveidei. Katram maǵistrantam bija jāsniedz vismaz viena augstas kvalitātes intervija. Intervijas tika veiktas divās valodās: latviešu (studenti no Latvijas) un angḷ (ārzemju studenti). Tas radīja papildu grūtības ārzemju studentiem, intervējot Latvijas sociālās inovācijas projektu pārstāvjus un veicot kvalitatīvo kontentanalīzi, jo viss intervijas materiāls bija jātulko angḷu valodā. Tāpēc arī viṇiem tika nozīmēti konsultanti - maǵistranti no Latvijas. 


\subsection{Datu analīzes veikšanas loǵika}

Sociālās inovācijas projektu intervijās iegūto datu analīzei tika veiktas:

- kvantitatīvo datu par šķēršliem, kuri kavē sociālās inovācijas procesus konkrētā institūcijā vai projektā, analīze. Dati tika iegūti, ñemot vērā atbildes uz slēgto jautājumu ar astoṇām piedāvātām izvēlēm un iespēju tās papildināt;

- interviju tekstu kvalitatīvā kontentanalīze ar atvērtu kodēšanu saskañā ar Filipa Meiringa (Philipp Mayring) induktīvo kategoriju attīstības modeli (Mayring, 2000), lai noteiktu un definētu līdzeklus un mehānismus, kuri dažādos veidos tika pielietoti, lai pārvarētu minētos sociālās inovācijas šksēršlus konkrētā institūcijā vai projektā;

- kategoriju biežumu tabulas analīze ar mērksi noteikt, kuri no līdzekḷiem un mehānismiem tiek biežāk pielietoti, pārvarot sociālās inovācijas šksēršlıus;

- integrētā "šksēršl̦i - to pārvarēšanas līdzekḷi un mehānismi" analīze, lai gūtu ieskatu par to, kuri no līdzekḷiem un mehānismiem tiek pielietoti katra šķēěšla pārvarēšanā.

\subsection{Galvenie sociālās inovācijas šḳērṣ̣̌i Latvijā}

Intervijas atklāja galvenos šḳēršlus, ar kuriem saskaras sociālās inovācijas projekti. Respondentiem piedāvāja izvēlēties no astoṇiem šksēršlıiem, kuri tika noteikti teorētiskajā analīzē. Respondents varēja norādīt vairāk nekā vienu šksēršli, kā arī dalīties pieredzē par dažiem citiem šksēršlıiem, kuri nebija iekḷauti sarakstā. Katra šksēršla svars tika noteikts, pamatojoties uz tā sastopamības biežumu atbildēs. Lai salīdzinātu, kādi škēēšli sociālās inovācijas projektiem Latvijā ir tipiskāki un akūtāki, šḳēršḷu svaru sadalījums tika attēlots diagrammā (sk. 4. attēlu).

Visnopietnākie sociālās inovācijas škēēșli Latvijā ir finansējuma trūkums (24\%), pasivitāte sabiedrībā (19 \%) un administratīvie un birokrātiskie šksēršlı (19 \%). Pārējiem škēēršliem ir līdzīgi svari (6-9 \%). Tas liecina par līdzīgām negatīvām lomām, kuras sociālo inovāciju projektu ìstenošanā spēlē sabiedrības atvērtības trūkums citu cilvēku pieredzei un sadarbībai (9 \%), tiesiskā regulējuma trūkums (8\%), ieinteresēto pušu pasivitāte un zema līmeņa atbalsts (8\%), pieredzes trūkums projektu realizācijā (7\%) un nepieciešamās informācijas trūkums (6\%). Atkarībā no tā, kas nosaka šos sociālās inovācijas šksēršlus, tos var sadalìt trīs grupās: 
1) šksēršlli, kas vairāk saistīti ar indivīda kvalitātēm un rakstura īpašībām, - atvērtības trūkums citu cilvēku pieredzei un sadarbībai (9\%) un pieredzes trūkums projektu realizācijā (7 \%);

2) šķēršli, kas raksturo sabiedrības dzīves organizāciju un iekārtu kopumā, - pasivitāte sabiedrībā (19 \%), iesaistīto pušu pasivitāte un zema līmeña atbalsts (8\%), finansējuma trūkums (24\%) un informācijas trūkums (6\%);

3) šķēršlıi, kas attiecas uz tiesiskām un formāli regulējamām attiecībām starp indivīdiem un/vai organizācijām, - administratīvie un birokrātiskie šķērṣ̦̌i (19 \%) un tiesiskā regulējuma trūkums (8 \%).

Redzams, ka šie šķēršlı savā starpā ir cieši cēlonssakarīgi saistīti. Piemēram, administratīvie un birokrātiskie šḳērṣ̌li var izraisīt sabiedrības pasivitāti, jo daudzi cilvēki nesaskata jēgu rīkoties, lai atrisinātu aktuālas problēmas sabiedrībā, jo ar formālām barjerām uzreiz tiks iznicināta vinu iniciatīva. Savukārt finansējuma trūkums var izraisīt ieinteresēto pušu pasivitāti un niecīgu atbalstu, jo bez nepieciešamā finansējuma visas ieceres var palikt tikai idejas līmenī. Bet tiesiskā regulējuma trūkums var novest pie administratīvajiem un birokrātiskajiem šķēršlliem, jo, ja sabiedrībā nepastāv precīzi noteikta sociālo inovāciju regulējoša normatīvā bāze, katra amatpersona uz vietas var izdomāt savus uzstādijjumus un pienemt lēmumus atbilstoši savai izpratnei un gatavībai rīkoties.

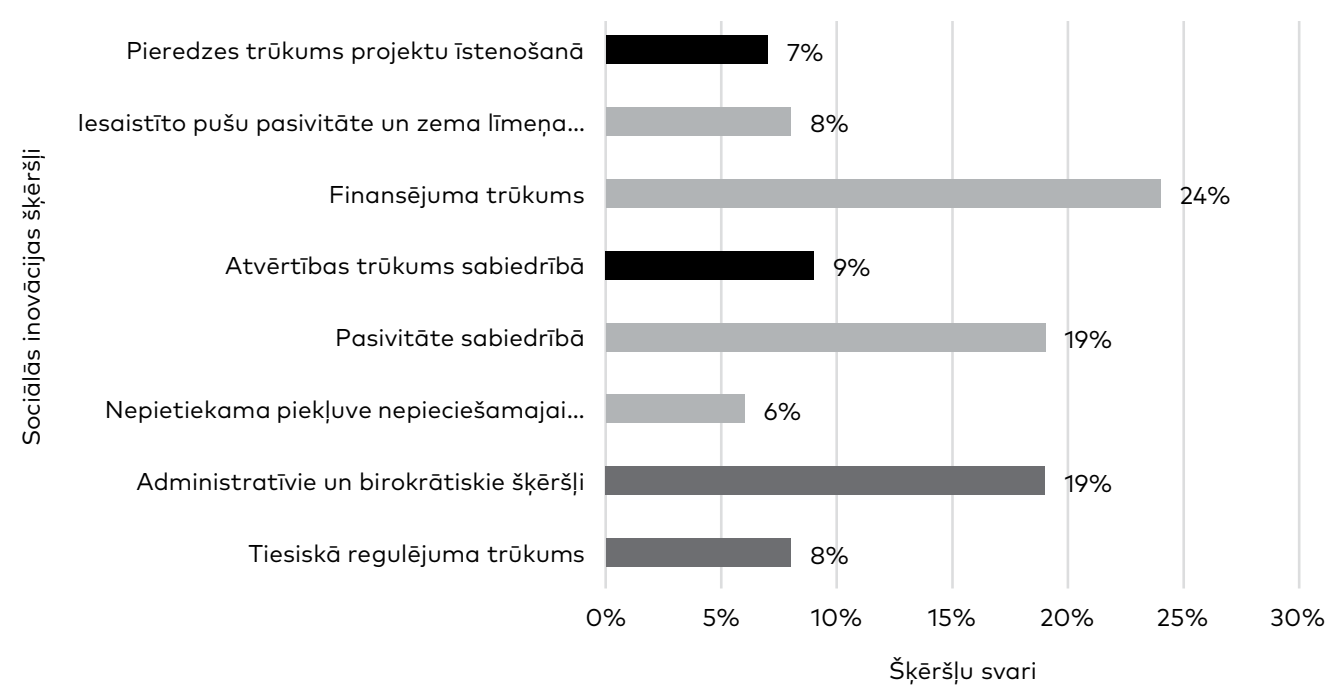

Avots: Oganisjana, Eremina, Gvatua, Kabwende \& Chukwu, 2017: 35.

4. attēls. Sociālās inovācijas šḳēršli Latvijā, projektu kopskaits $n=115$. 
Tā kā respondentiem tika piedāvāts aprakstīt arī citus šḳēršlus, ar kuriem viṇi sastopas savos projektos, īpaša uzmanība tika pievērsta tieši šìm atbildēm. Tomēr no atsevišķu tekstu analīzes netika izveidotas jaunas kategorijas, lai papildinātu astoṇus jau sākotnēji definētos šķēršl̦us. Dažos gadījumos bija saistība ar šiem astoṇiem šķēršlıem, bet respondenti ne vienmēr apzinājās šo saistību. Piemēram, fragments "skolas negribēšana pien,emt, ka banka vienkārši vēlas izglītot jauniešus, nevis pārdot savus pakalpojumus" ir cēlon,sakarīgi saistīts ar šḳērsli "sabiedrības atvērtības trūkums citu cilvēku pieredzei un sadarbībai". Tomēr respondents to raksturoja kā vēl vienu citu ārpus šì saraksta esošu škēērsli.

\subsection{Kā Latvijā tiek pārvarēti sociālās inovācijas šḳēršli}

Katrs intervētais projekta pārstāvis dalījās savā pieredzē par to, ar kādiem paṇēmieniem un problēmu risināšanas mehānismiem viṇš pārvar vai pārvarēja šḳēršlı sus sava projekta īstenošanas laikā. Atbildes tekstu kvalitatīvās kontentanalīzes gaitā tika attīstītas deviṇas kategorijas (sk. 5. attēlu).

5. attēla diagrammā redzams, ka esošo šksēršlu pārvarēšanai intervētie sociālās inovācijas projektu pārstāvji visbiežāk minēja sekmēšanas un popularizēšanas pasākumus (24\%). Sekmēšanas un popularizēšanas pasākumus pētījuma komanda definēja kā aktivitāšu kopumu, kuru mērķis ir izglītot sabiedrību, mudināt ieinteresētās personas piedalīties projektā, vairot izpratni par risināmās problēmas aktualitāti un apmainīties ar informāciju par problēmu risinājumiem ar mērḳa grupu un citiem. Galvenie rīki, ko izmantoja respondenti, bija mediji, labdarības pasākumi, mutvārdos, prezentācijas un tikšanās. Kā norādījuši intervētie, "projekta aktivitātes tika organizētas informatīvo semināru ietvaros" vai "tiek ieguldīts daudz līdzekḷu, lai izskaidrotu projekta misiju, redzējumu" utt.

Nozīmīga loma sociālās inovācijas projektu šksēršlu pārvarēšanā ir ārējam finansiālajam atbalstam (16\%), kas sastāv no projektam piesaistītā finansējuma no atsevišksiem sponsoriem, komercuzṇēmumiem, valsts iestādēm vai valsts atbalsta un subsīdījām. Respondenti minēja: "Mēs meklējām sponsorus un atbalstītājus" vai "Mēs piesaistījām līdzfinansējumu no vietējās pašvaldības”. Šḳēršlu pārvarēšanas ārējais organizatoriskais atbalsts (16\%), tostarp ieinteresēto personu palīdzība, materiālo vērtību ziedojums, dažādu iestāžu organizatoriskā palīdzība, ir tikpat svarīgs kā finansiālais atbalsts. Par ārējo atbalstu intervētie izteicās dažādi: "Cilvēki strādāja brīvprātīgi...", "Mēs varējām atrast cilvēkus un uzṇēmumus, kuri ticēja mums un 
palīdzēja", "Viṇi sniedza padomus un iedvesmu, ziedoja krāsainus audumus..." u. c.

Arī komunikācijai ar ieinteresētajām pusēm (12 \%) ir būtiska nozīme šksēršlı pārvarēšanā, jo sociālās inovācijas projekti iesaista sabiedrību un iepazīstina to ar idejām par dažādiem sociālo problēmu risināšanas paṇēmieniem.

Projekta grupas kompetences (11\%) ir sociālās inovācijas škēēšlu pārvarēšanas būtisks līdzeklis. Šì kategorija apvieno sevī projekta komandas idejas, prasmes, problēmu risināšanas spējas, resursus un iniciatīvas.

Vairākos gadījumos projekta norises gaitā bija jāveic izmaiṇas, lai pārvarētu šksēršlus. Projekta modifikācija (9 \%) var tikt izskaidrota kā iekšējās izmaiṇas un projekta uzlabojumi, lai pielāgotos spēkā esošo normatīvo aktu prasībām un noteikumiem.

Informācija ir nozīmīgs resurss, tāpēc bija gaidīts, ka ārējam informācijas atbalstam (8 \%) būs izšksiroša loma šksēršlı pārvarēšanā. Respondenti saṇēma informāciju, konsultējoties ar kolēgiem, ekspertiem

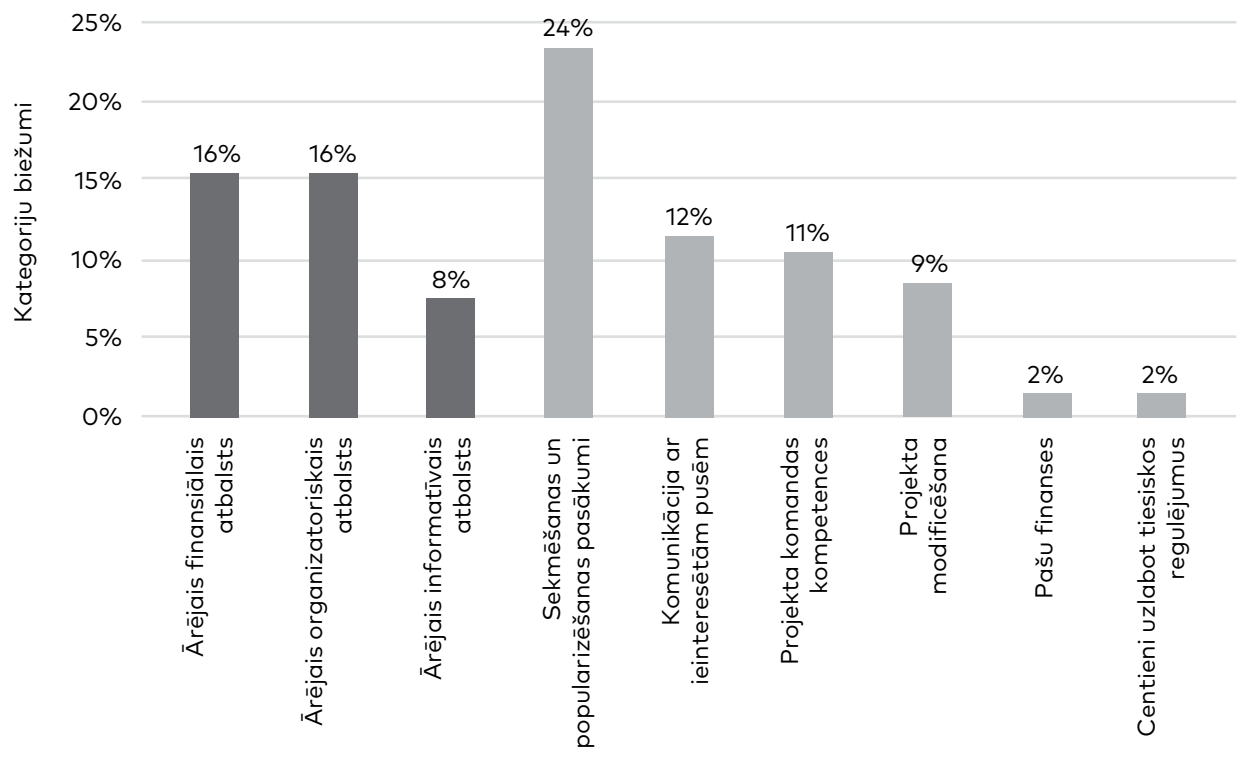

Sociālās inovācijas šḳērš|u pārvarēšanas līdzek!̣i un mehānismi

Avots: Oganisjana, Eremina, Gvatua, Kabwende \& Chukwu, 2017: 36.

5. attēls. Sociālās inovācijas šḳēršlu pārvarēšanas līdzekḷu un mehānismu frekvenču sadalïjums, projektu kopskaits $n=115$. 
un speciālistiem savā vidē vai ārzemēs, piedalījās mācību kursos, veica aptaujas un analizēja tiešsaistes informācijas avotus.

Neraugoties uz to, ka divas šksērṣ̌ı pārvarēšanas līdzekḷ kategorijas - centieni uzlabot tiesisko regulējumu (2\%) un pašu finanses (2 \%) - tika minētas retāk, daži projekti vēl joprojām pārvarēja šķērṣ̌lus, pateicoties tieši šiem šķēršlı pārvarēšanas līdzekḷiem un mehānismiem.

Centieni uzlabot tiesisko regulējumu apvieno procedūras, kuru mērķis ir piedalīties sociālās inovācijas likumdošanas izstrādē un pilnveidošanā.

Kategorija "pašu kapitāls" tiek saprasta kā finansiāls ieguldījums, ko veikusi galvenā projekta komanda, lai atrisinātu problēmas, kas radušās projekta īstenošanas vai attīstīšanas (mērogošanas) gaitā.

Līdzekḷus un mehānismus, ar kuru palīdzību šodien sociālās inovācijas projekti pārvar škēesšḷus, var sadalīt divās grupās:

- iekšējie līdzekḷi, kurus pielieto un iedarbina paši sociālie inovācijas īstenotāji, - sekmēšanas un popularizēšanas pasākumi (24 \%), komunikācija ar ieinteresētajām pusēm (12\%), projekta grupas kompetences (11\%), projekta modifikācija ( $9 \%)$, pašu finanses (2\%) un centieni uzlabot tiesisko regulējumu (2\%);

- ārējie resursi, kas tiek sañemti no sociālās inovācijas īstenotājiem, - ārējais finansiālais atbalsts (16\%), ārējais organizatoriskais atbalsts (16\%) un ārējais informatīvais atbalsts (8\%).

\subsection{Sociālās inovācijas šḳēršlu un to pārvarēšanas līdzek!̣u un mehānismu kopanalīze}

Zinātniskajā literatūrā sociālās inovācijas šḳēeršlıi un to pārvarēšanas līdzekḷi un mehānismi parasti tiek pētīti atsevišķi un neatkarīgi cits no cita. Šajā pētījumā katrs sociālās inovācijas šķērslis tika pētìts kopsakarībā ar tā pārvarēšanas līdzekḷiem un mehānismiem, jo ir svarīgi zināt, kā var pārvarēt katru no šḳēršșiem.

Lai to realizētu, pētījuma pēdējā posmā katrs no 115 intervijās atzīmētajiem šksēeršliem tika vēlreiz analizēts saistībā ar līdzekḷiem un mehānismiem, kurus pielietoja šo šksēršlu pārvarēšanā. Analīzes rezultātā tika izveidota 4. tabulā attēlotā matrica. Katrā horizontālajā numurētajā rindā parādīts viens no astoṇiem šķērṣ̌̆liem kombinācijā ar katru no deviņiem līdzekḷiem un mehānismiem, un zem katras kombinācijas doti tās biežumi, tas ir, cik reizes visās intervijās kopumā bija minēta konkrēta škēeršlı pārvarēšana ar attiecīgo līdzekli vai mehānismu. Krāsās akcentētas tās šḳēršlu un to pārvarēšanas līdzekḷu un mehānismu kombinācijas, kuras visvairāk reižu bija minētas interviju laikā saistībā ar konkrētā šksērș̣la pārvarēšanu.
Karine Oganisjana, 


\section{4. tabula}

Sociālās inovācijas šḳēršḷ un to pārvarēšanas līdzekḷu un mehānismu kopanalīzes matrica

\begin{tabular}{|c|c|c|c|c|}
\hline 1. & $\begin{array}{c}\text { Tiesiskā regulējuma } \\
\text { trūkums } \\
+ \\
\text { Ārējais finansiālais } \\
\text { atbalsts }\end{array}$ & $\begin{array}{c}\text { Tiesiskā regulējuma } \\
\text { trūkums } \\
+ \\
\text { Sekmēšanas un } \\
\text { popularizēšanas } \\
\text { pasākumi }\end{array}$ & $\begin{array}{c}\text { Tiesiskā regulējuma } \\
\text { trūkums } \\
+ \\
\begin{array}{c}+ \\
\text { Ārējais informatīvais } \\
\text { atbalsts }\end{array}\end{array}$ & $\begin{array}{c}\text { Tiesiskā regulējuma } \\
\text { trūkums } \\
+ \\
\text { Projekta modificēšana }\end{array}$ \\
\hline & 5 & 8 & 3 & 4 \\
\hline \multirow[t]{2}{*}{2.} & $\begin{array}{c}\text { Administratīvie un } \\
\text { birokrātiskie škēerṣ̌̆li } \\
+ \\
\begin{array}{c}\text { Arējais finansiālais } \\
\text { atbalsts }\end{array}\end{array}$ & $\begin{array}{c}\text { Administratīivie un } \\
\text { birokrātiskie šḳēerṣ̌i } \\
+ \\
\text { Sekmēšanas un } \\
\text { popularizēšanas } \\
\text { pasākumi }\end{array}$ & $\begin{array}{c}\text { Administratīvie un } \\
\text { birokrātiskie šḳērṣ̌li } \\
+ \\
\text { Ārējais informatīvais } \\
\text { atbalsts }\end{array}$ & $\begin{array}{c}\text { Administratīivie un } \\
\text { birokrātiskie šḳēršḷi } \\
+ \\
\text { Projekta modificēšana }\end{array}$ \\
\hline & 6 & 8 & 7 & 6 \\
\hline \multirow[t]{2}{*}{3.} & $\begin{array}{c}\text { Nepietiekama } \\
\text { piek|uve } \\
\text { nepieciešamajai } \\
\text { informācijai } \\
+ \\
\text { Ārējais finansiālais } \\
\text { atbalsts }\end{array}$ & $\begin{array}{c}\text { Nepietiekama piekluve } \\
\text { nepieciešamajai } \\
\text { informācijai } \\
+ \\
\text { Sekmēšanas un } \\
\text { popularizēšanas } \\
\text { pasākumi }\end{array}$ & $\begin{array}{c}\text { Nepietiekama piek|uve } \\
\text { nepieciešamajai } \\
\text { informācijai } \\
+ \\
\text { Ārējais informatīvais } \\
\text { atbalsts }\end{array}$ & $\begin{array}{c}\text { Nepietiekama piekluve } \\
\text { nepieciešamajai } \\
\text { informācijai } \\
+ \\
\text { Projekta modificēšana }\end{array}$ \\
\hline & 3 & 8 & 4 & 1 \\
\hline \multirow[t]{2}{*}{4.} & $\begin{array}{c}\text { Pasivitāte } \\
\text { sabiedrībā } \\
+ \\
\text { Ārējais finansiālais } \\
\text { atbalsts }\end{array}$ & $\begin{array}{c}\text { Pasivitāte sabiedrībā } \\
+ \\
\text { Sekmēšanas un } \\
\text { popularizēšanas } \\
\text { pasākumi }\end{array}$ & $\begin{array}{c}\text { Pasivitāte sabiedrībā } \\
+ \\
\begin{array}{c}+ \\
\text { Ārējais informatīvais } \\
\text { atbalsts }\end{array}\end{array}$ & $\begin{array}{c}\text { Pasivitāte sabiedrībā } \\
+ \\
\text { Projekta modificēšana }\end{array}$ \\
\hline & 11 & 26 & 3 & 3 \\
\hline \multirow[t]{2}{*}{5.} & $\begin{array}{c}\text { Atvērtības trūkums } \\
\text { sabiedrībā } \\
+ \\
\begin{array}{c}+ \\
\text { Ārējais finansiālais } \\
\text { atbalsts }\end{array}\end{array}$ & $\begin{array}{c}\text { Atvērtības trūkums } \\
\text { sabiedrībā } \\
+ \\
\text { Sekmēšanas un } \\
\text { popularizēšanas } \\
\text { pasākumi }\end{array}$ & $\begin{array}{c}\text { Atvērtības trūkums } \\
\text { sabiedrībā } \\
+ \\
\begin{array}{c}+ \\
\text { Ārējais informatīvais } \\
\text { atbalsts }\end{array}\end{array}$ & $\begin{array}{c}\text { Atvērtības trūkums } \\
\text { sabiedrībā } \\
+ \\
\text { Projekta modificēšana }\end{array}$ \\
\hline & 5 & 9 & 3 & 2 \\
\hline \multirow[t]{2}{*}{6.} & $\begin{array}{c}\text { Finansējuma } \\
\text { trūkums } \\
+ \\
\text { Ārējais finansiālais } \\
\text { atbalsts }\end{array}$ & $\begin{array}{c}\text { Finansējuma trūkums } \\
+ \\
\begin{array}{c}\text { Sekmēšanas un } \\
\text { popularizēšanas } \\
\text { pasākumi }\end{array}\end{array}$ & $\begin{array}{c}\text { Finansējuma trūkums } \\
+ \\
\begin{array}{c}+ \\
\text { Ārējais informatīvais } \\
\text { atbalsts }\end{array}\end{array}$ & $\begin{array}{c}\text { Finansējuma trūkums } \\
+ \\
\text { Projekta modificēšana }\end{array}$ \\
\hline & 25 & 19 & 6 & 6 \\
\hline
\end{tabular}




\begin{tabular}{|c|c|c|c|c|}
\hline $\begin{array}{c}\text { Tiesiskā regulējuma } \\
\text { trūkums } \\
+\end{array}$ & $\begin{array}{c}\text { Tiesiskā regulējuma } \\
\text { trūkums } \\
+ \\
\text { Komunikācija ar } \\
\text { ieinteresētām } \\
\text { pusēm }\end{array}$ & $\begin{array}{c}\text { Tiesiskā regulējuma } \\
\text { trūkums } \\
+ \\
\text { Pašu finanses }\end{array}$ & $\begin{array}{c}\text { Tiesiskā regulējuma } \\
\text { trūkums } \\
+ \\
\text { Centieni uzlabot } \\
\text { tiesiskos } \\
\text { regulējumus }\end{array}$ & $\begin{array}{c}\text { Tiesiskā regulējuma } \\
\text { trūkums } \\
+ \\
\text { Projekta komandas } \\
\text { kompetence }\end{array}$ \\
\hline 3 & 3 & 0 & 4 & 1 \\
\hline $\begin{array}{c}\text { Administratīvie } \\
\text { un birokrātiskie } \\
\text { šḳēršli } \\
+\end{array}$ & $\begin{array}{c}\text { Administratīvie } \\
\text { un birokrātiskie } \\
\text { škēršli } \\
+ \\
\text { Komunikācija ar } \\
\text { ieinteresētām } \\
\text { pusēm }\end{array}$ & $\begin{array}{c}\text { Administratīvie } \\
\text { un birokrātiskie } \\
\text { šḳēršli } \\
+ \\
\text { Pašu finanses }\end{array}$ & $\begin{array}{c}\text { Administratīvie } \\
\text { un birokrātiskie } \\
\text { šḳēršli } \\
+\end{array}$ & $\begin{array}{c}\text { Administratīivie } \\
\text { un birokrātiskie } \\
\text { šḳēršli } \\
+ \\
\text { Projekta komandas } \\
\text { kompetence }\end{array}$ \\
\hline 12 & 7 & 3 & 2 & 10 \\
\hline $\begin{array}{c}\text { Nepietiekama } \\
\text { piekluve } \\
\text { nepieciešamajai } \\
\text { informācijai } \\
+ \\
\text { Ārējais organizato- } \\
\text { riskais atbalsts }\end{array}$ & $\begin{array}{c}\text { Nepietiekama } \\
\text { piekluve } \\
\text { nepieciešamajai } \\
\text { informācijai } \\
+ \\
\text { Komunikācija ar } \\
\text { ieinteresētām } \\
\text { pusēm }\end{array}$ & $\begin{array}{l}\text { Nepietiekama } \\
\text { piek|uve } \\
\text { nepieciešamajai } \\
\text { informācijai } \\
+ \\
\text { Pašu finanses }\end{array}$ & $\begin{array}{c}\text { Nepietiekama } \\
\text { piek|uve } \\
\text { nepieciešamajai } \\
\text { informācijai } \\
+ \\
\text { Centieni uzlabot } \\
\text { tiesiskos } \\
\text { regulējumus }\end{array}$ & $\begin{array}{c}\text { Nepietiekama } \\
\text { piek|uve } \\
\text { nepieciešamajai } \\
\text { informācijai } \\
+ \\
\text { Projekta komandas } \\
\text { kompetence }\end{array}$ \\
\hline 1 & 3 & 1 & 0 & 1 \\
\hline $\begin{array}{c}\text { Pasivitāte } \\
\text { sabiedrībā } \\
+ \\
\text { Ārējais organizato- } \\
\text { riskais atbalsts }\end{array}$ & $\begin{array}{c}\text { Pasivitāte } \\
\text { sabiedrībā } \\
+ \\
\text { Komunikācija ar } \\
\text { ieinteresētām } \\
\text { pusēm }\end{array}$ & $\begin{array}{c}\text { Pasivitāte } \\
\text { sabiedrībā } \\
+ \\
\text { Pašu finanses }\end{array}$ & $\begin{array}{c}\text { Pasivitāte } \\
\text { sabiedrībā } \\
+ \\
\text { Centieni uzlabot } \\
\text { tiesiskos } \\
\text { regulējumus }\end{array}$ & $\begin{array}{c}\text { Pasivitāte } \\
\text { sabiedrībā } \\
+ \\
\text { Projekta komandas } \\
\text { kompetence }\end{array}$ \\
\hline 6 & 8 & 3 & 1 & 4 \\
\hline $\begin{array}{c}\text { Atvērtības trūkums } \\
\text { sabiedrībā } \\
+ \\
\text { Ārējais organizato- } \\
\text { riskais atbalsts }\end{array}$ & $\begin{array}{c}\text { Atvērtības trūkums } \\
\text { sabiedrībā } \\
+ \\
\text { Komunikācija ar } \\
\text { ieinteresētām } \\
\text { pusēm }\end{array}$ & $\begin{array}{c}\text { Atvērtības trūkums } \\
\text { sabiedrībā } \\
+ \\
\text { Pašu finanses }\end{array}$ & $\begin{array}{c}\text { Atvērtības trūkums } \\
\text { sabiedrībā } \\
+ \\
\text { Centieni uzlabot } \\
\text { tiesiskos } \\
\text { regulējumus }\end{array}$ & $\begin{array}{c}\text { Atvērtības trūkums } \\
\text { sabiedrībā } \\
+ \\
\text { Projekta komandas } \\
\text { kompetence }\end{array}$ \\
\hline 3 & 3 & 1 & 0 & 3 \\
\hline $\begin{array}{c}\text { Finansējuma } \\
\text { trūkums } \\
+\end{array}$ & $\begin{array}{c}\text { Finansējuma } \\
\text { trūkums } \\
+ \\
\text { Komunikācija ar } \\
\text { ieinteresētām } \\
\text { pusēm }\end{array}$ & $\begin{array}{c}\text { Finansējuma } \\
\text { trūkums } \\
+ \\
\text { Pašu finanses }\end{array}$ & $\begin{array}{c}\text { Finansējuma } \\
\text { trūkums } \\
+ \\
\text { Centieni uzlabot } \\
\text { tiesiskos } \\
\text { regulējumus }\end{array}$ & $\begin{array}{c}\text { Finansējuma } \\
\text { trūkums } \\
+ \\
\text { Projekta komandas } \\
\text { kompetence }\end{array}$ \\
\hline 14 & 5 & 3 & 1 & 8 \\
\hline
\end{tabular}




\section{4. tabulas turpinājums}

\begin{tabular}{|c|c|c|c|c|}
\hline 7. & $\begin{array}{c}\text { lesaistīto pušu } \\
\text { pasivitāte un zema } \\
\text { līmeṇa atbalsts } \\
+ \\
\text { Ārējais finansiālais } \\
\text { atbalsts }\end{array}$ & $\begin{array}{c}\text { lesaistīto pušu pasivitāte } \\
\text { un zema līmeṇa at- } \\
\text { balsts } \\
+ \\
\text { Sekmēšanas un } \\
\text { popularizēšanas } \\
\text { pasākumi }\end{array}$ & $\begin{array}{c}\text { lesaistīto pušu pasivitāte } \\
\text { un zema līmeṇa at- } \\
\text { balsts } \\
+ \\
\text { Ārējais informativais } \\
\text { atbalsts }\end{array}$ & $\begin{array}{c}\text { lesaistīto pušu pasivitāte } \\
\text { un zema līmeṇa at- } \\
\text { balsts } \\
+ \\
\text { Projekta modificēšana }\end{array}$ \\
\hline & 4 & 7 & 2 & 1 \\
\hline 8. & $\begin{array}{c}\text { Pieredzes trūkums } \\
\text { projekta } \\
\text { istenošanā } \\
+ \\
\text { Ārējais finansiālais } \\
\text { atbalsts }\end{array}$ & $\begin{array}{c}\text { Pieredzes trūkums pro- } \\
\text { jekta īstenošanā } \\
+ \\
\text { Sekmēšanas un } \\
\text { popularizēšanas } \\
\text { pasākumi }\end{array}$ & $\begin{array}{c}\text { Pieredzes trūkums pro- } \\
\text { jekta īstenošanā } \\
+ \\
\text { Ārējais informatīvais } \\
\text { atbalsts }\end{array}$ & $\begin{array}{c}\text { Pieredzes trūkums pro- } \\
\text { jekta īstenošanā } \\
+ \\
\text { Projekta modificēšana }\end{array}$ \\
\hline & 1 & 0 & 6 & 1 \\
\hline
\end{tabular}

Matrica rāda, ka viens sociālās inovācijas šḳērslis tiek pārvarēts ar dažādiem līdzekḷiem. Tas nozīmē, ka nepastāv tikai viena universāla pieeja katra šksēršla pārvarēšanā. Tādējādi pie pozitīviem rezultātiem var novest dažādu līdzekḷu, pieeju un mehānismu kombinācija. Piemēram, attiecībā uz administratīvā un birokrātiskā škēešșla pārvarēšanu viens no intervētājiem runāja par četriem no deviṇiem līdzekḷiem un mehānismiem: "Es piesaistīju naudu ("ārējais finansiālais atbalsts"), esmu atbildīgs par lietām, izmantojot visu to, ko esmu spējīgs darīt ("projekta komandas kompetence"), izmantoju plašu tīklu loku ("sekmēšanas un popularizēšanas pasākumi") un veltīja savus personīgos resursus ("pašu finanses")".

Tomēr atsevišksās kombinācijās daži līdzekḷi un mehānismi problēmu pārvarēšanā tika minēti biežāk nekā citi.

Sekmēšanas un popularizēšanas pasākumiem bija visizšķirošākā loma gandrīz visu veidu škēēšlı pārvarēšanā, izn,emot pieredzes trūkuma projekta īstenošanā. Kopā ar sekmēšanas un popularizēšanas pasākumiem ( $n=8)$ administratīvie un birokrātiskie šķēršlı tika pārvarēti, pateicoties ārējam organizatoriskajam atbalstam $(n=12)$, projekta komandas kompetencēm $(n=10)$, ārējam informatīvajam atbalstam $(n=7)$ un komunikācijai ar ieinteresētajām pusēm $(n=7)$. Pasivitāte sabiedrībā tika pārvarēta, pateicoties ārējam finansiālajam atbalstam $(n=11)$ un komunikācijai ar ieinteresētajām pusēm $(n=8)$, tomēr visspēcīgākais šḳēršlu pārvarēšanas mehānisms izrādījās sekmēšanas un popularizēšanas pasākumi, kurus minēja 26 intervētie. Finansējuma trūkums tika pārvarēts ar ārējo finansiālo atbalstu $(n=25)$, ārējo organizatorisko atbalstu $(n=14)$ un pateicoties projekta komandas kompetencēm 


\begin{tabular}{|c|c|c|c|c|}
\hline $\begin{array}{c}\text { lesaistīto pušu } \\
\text { pasivitāte un } \\
\text { zema līmeṇa } \\
\text { atbalsts } \\
+ \\
\text { Ārējais organizato- } \\
\text { riskais atbalsts }\end{array}$ & $\begin{array}{c}\text { lesaistīto pušu } \\
\text { pasivitāte un } \\
\text { zema līmeṇa } \\
\text { atbalsts } \\
+ \\
\text { Komunikācija ar } \\
\text { ieinteresētām } \\
\text { pusēm }\end{array}$ & $\begin{array}{c}\text { lesaistīto pušu } \\
\text { pasivitāte un } \\
\text { zema līmeña } \\
\text { atbalsts } \\
+ \\
\text { Pašu finanses }\end{array}$ & $\begin{array}{c}\text { lesaistīto pušu } \\
\text { pasivitāte un } \\
\text { zema līmeṇa } \\
\text { atbalsts } \\
+ \\
\text { Centieni uzlabot } \\
\text { tiesiskos } \\
\text { regulējumus }\end{array}$ & $\begin{array}{c}\text { lesaistīto pušu } \\
\text { pasivitāte un } \\
\text { zema līmeṇa } \\
\text { atbalsts } \\
+ \\
\text { Projekta komandas } \\
\text { kompetence }\end{array}$ \\
\hline 5 & 6 & 1 & 1 & 4 \\
\hline $\begin{array}{c}\text { Pieredzes trūkums } \\
\text { projekta } \\
\text { istenošanā } \\
+ \\
\text { Ārējais organizato- } \\
\text { riskais atbalsts }\end{array}$ & $\begin{array}{c}\text { Pieredzes trūkums } \\
\text { projekta } \\
\text { istenošanā } \\
+ \\
\text { Komunikācija ar } \\
\text { ieinteresētām } \\
\text { pusēm }\end{array}$ & $\begin{array}{c}\text { Pieredzes trūkums } \\
\text { projekta } \\
\text { istenošanā } \\
+ \\
\text { Pašu finanses }\end{array}$ & $\begin{array}{c}\text { Pieredzes trūkums } \\
\text { projekta } \\
\text { istenošanā } \\
+ \\
\text { Centieni uzlabot } \\
\text { tiesiskos } \\
\text { regulējumus }\end{array}$ & $\begin{array}{c}\text { Pieredzes trūkums } \\
\text { projekta } \\
\text { istenošanā } \\
+ \\
\text { Projekta komandas } \\
\text { kompetence }\end{array}$ \\
\hline 3 & 0 & 0 & 0 & 3 \\
\hline
\end{tabular}

Avots: Oganisjana, Eremina, Gvatua, Kabwende \& Chukwu, 2017: 37.

( $n=8)$. Pieredzes trūkums projekta īstenošanā galvenokārt tika pārvarēts, pateicoties ārējam informatīvajam atbalstam $(n=6)$.

\section{Secinājumi}

Atbilstoši sociālās inovācijas projektu ietvaros veiktajām intervijām sociālās inovācijas šķēèšli Latvijā ir savā starpā cēloṇsakarīgi saistīti.

- Indivīdu raksturojuma līmenī šos škēršlıs rada atvērtības trūkums citu cilvēku pieredzei un sadarbībai un pieredzes trūkums projektu realizēšanā.

- Visas sabiedrības līmenī kopumā šie šḳēršli ir saistīti ar sabiedrības pasivitāti un zemu atbalsta līmeni, finansējuma un informācijas trūkumu.

- Formāli tiesiskajā līmenī šie šķēeršli ir saistīti ar administratīvajiem un birokrātiskajiem šḳēršlıiem un tiesiskā regulējuma trūkumu.

Tātad, salīdzinot sociālās inovācijas projektu intervēšanā iegūtos datus ar fokusgrupas diskusijā noteiktajiem sociālo inovāciju kavējošajiem faktoriem (sk. 3. nodalı)u, var saskatīt, ka tie dal̦ēji sakrīt: 1) atvērtības trūkums citu cilvēku pieredzei vai jaunai pieredzei; 2) pasivitāte sabiedrībā; 3) pieredzes trūkums sociālo projektu realizācijā; 4) administratīvie un birokrātiskie škēēšli. Tomēr sociālās inovācijas projekti akcentēja arī citus faktorus, kurus nosaka iesaistīto pušu pasivitāte un zems atbalsta līmenis, finansējuma trūkums, informācijas trūkums, kā arī tiesiskā regulējuma trūkums. Tas ir izskaidrojams ar faktu, ka 
sociālās inovācijas projekti tieši saskaras ar šādiem šķēršliem un spēj precīzi aprakstīt tos. Tajā pašā laikā ne visiem fokusgrupas diskusijas dalībniekiem ir bijusi sociālās inovācijas projektu īstenošanas pieredze, taču viṇi ir bijuši eksperti jomās, kuras varētu būt saistītas ar sociālo inovāciju.

Šo sociālās inovācijas projektu šķēešslu pārvarēšanai tiek pielietotas dažādas iekšējo un ārējo līdzekḷu un mehānismu kombinācijas:

- aktīvi organizējot projekta sekmēšanas un popularizēšanas pasākumus, komunicējot ar ieinteresētajām pusēm, efektīvi pielietojot projekta komandas kompetences, veicot projekta modifikāciju nepieciešamības gadījumos, izmantojot savus finanšu resursus un pat cenšoties uzlabot tiesisko regulējumu (iekšējie līdzekḷi un mehānismi);

- izmantojot ārējo finansiālo, organizatorisko un informatīvo atbalstu (ārējie līdzekḷi un mehānismi).

Visspēcīgākie līdzekḷi sociālās inovācijas šķēeṣ̌lu pārvarēšanā Latvijā ir sekmēšanas un popularizēšanas pasākumi, ārējais finansiālais atbalsts un ārējais organizatoriskais atbalsts.

Sociālās inovācijas projektu intervijās iegūto datu kvalitatīvā kontentanalīze arī atklāja tās pašas trīs ārējā atbalsta dimensijas finansiālo, informatīvo un organizatorisko atbalstu sociālās inovācijas projektiem. Šis secinājums vēl vairāk pastiprināja projekta komandas pārliecību, ka sabiedrības iesaisti sociālās inovācijas procesos vajadzētu analizēt tieši šajās trīs dimensijās - finansiālajā, informatīvajā un organizatoriskajā -, kas ir analizēts nākamajā nodaḷā. 


\section{SABIEDRĪBAS FINANSIĀLĀ,} INFORMATIVA $\overline{\text {, }}$

\section{ORGANIZATORISKĀ UN KOPËJĀ IESAISTE SOCIĀLĀS INOVĀCIJAS PROCESOS LATVIJĀ}

\section{KARINE OGANISJANA, NICOLAS MONGE-IRIARTE, KONSTANTINS KOZLOVSKIS, TĀLIS LAIZĀNS, SVETLANA SURIKOVA}

Pamatojoties uz atzin̄ām, kas gūtas zinātniskās literatūras analīzes gaitā, fokusgrupas diskusijās, intervijās ar valsts un privātā sektora uzñēmumu, Ekonomikas ministrijas un NVO pārstāvjiem, kā arī starptautiskajās aptaujās, 2016. gadā tika izstrādāta Latvijas sociālās inovācijas projektu interviju metodoloǵija un materiāli ar mērḳi radīt sabiedrības iesaistes sociālās inovācijas procesos modeli. Šajā darba posmā komandai pievienojās Nicolas Monge-Iriarte, kolēgis no Čīles, kuram bija liela pieredze sociālās inovācijas veicināšanas praksē Latīṇamerikā, vadot tiešsaistes platformu.

\subsection{Sociālās inovācijas projektu intervijas materiālu izstrāde}

Sociālās inovācijas projektu pārstāvju intervijas materiālu izstrādei tika lemts:

1) attīstīt jautājumus pēc sociālās inovācijas īstenošanas posmiem;

2) savākt informāciju par visu ieinteresēto pušu ieguldījumu sociālās inovācijas īstenošanā;

3) novērtēt sabiedrības iesaisti sociālās inovācijas procesos trīs dimensijās - finansiālajā, informatīvajā un organizatoriskajā. 


\section{Sociālās inovācijas īstenošanas posmi}

Intervijas materiāla izstrādes bāzi veidoja Eiropas Komisijas "Rokasgrāmata sociālajai inovācijai" (Guide to Social Innovation), kurā apgalvots, ka sociālā inovācija parasti attīstās četros posmos (sk. 6. attēlu):

1) idejas saskatīšana,

2) prototipu vai pilotprojekta izstrādāšana,

3) idejas īstenošana dzīvē,

4) prakses izplatīšana (European Commission, 2013: 9).

Tomēr literatūras analīzes rezultātā tika secināts, ka sociālā inovācija sākas ne tikai no idejas, bet drīzāk no aktuālas sociālās problēmas, kura vēl nav atrisināta pilnā mērā vai ir atrisināta daḷeji, vai arī ne l̦oti efektīvi (Phills et al., 2008; OECD, 2010; Dover, 2011; Minks, 2011; Mahmuda et al., 2014; Howaldt et al., 2014). Tādēl tiek atrasti labāki un efektīvāki sociālo problēmu risinājumi (Phills et al., 2008; Howaldt \& Schwarz, 2010; Minks, 2011; Cajaiba-Santana, 2013; Klievink \& Janssen, 2014).

Pateicoties sociālajai inovācijai, varētu tikt radīta jauna ilgtspējīga sociālā prakse un kultūra, tostarp jaunas organizācijas, jauna politika, jauni tehnologiskie risinājumi, jauna vērtību sistēma, mentalitāte utt. (sk. 1. un 2. nodal,u).

Specifisks sociālās inovācijas aspekts ir kopīga organizācija un ieinteresēto pušu kopīga domāšana, lai diagnosticētu vietējās sabiedrības

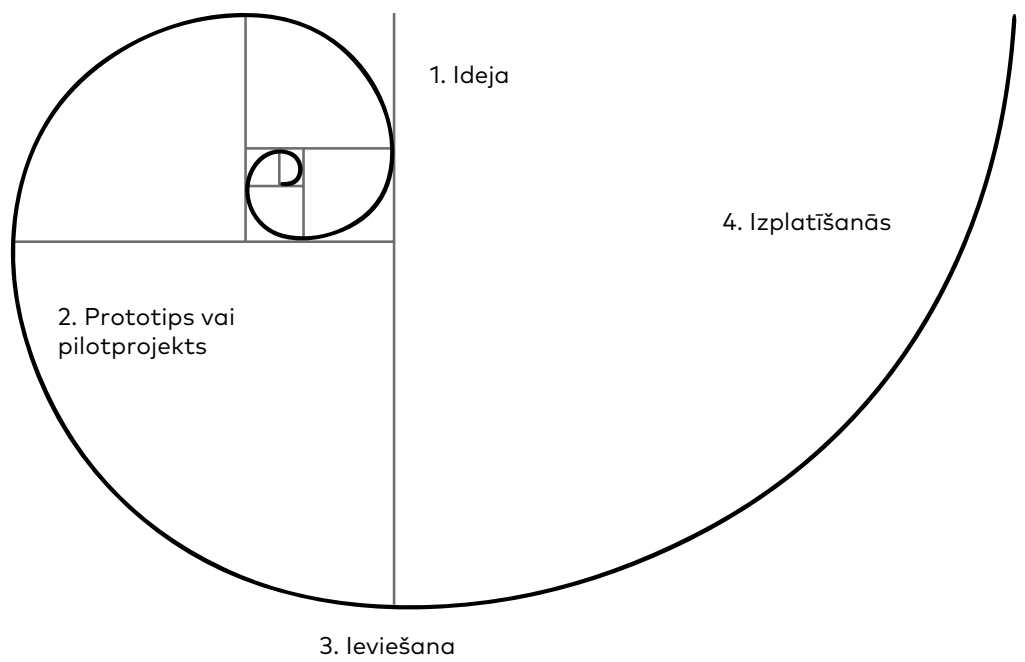

Avots: European Commission, 2013: 9.

6. attēls. Sociālās inovācijas četru posmu spirāles modelis. 
vai valsts sociālās problēmas, nosakot turpmākās prioritātes problēmas risināšanai (The Young Foundation, 2012a, 2012b; Davies \& Simons, 2012). Sociālās inovācijas process tiek īstenots trīs līmeños:

- delegéjot sociālās inovācijas radīšanas uzdevumu individuālajam uzñēmējam (mikro),

- veidojoties partnerībai "sabiedrība - privāts uzṇēmums" (mezo),

- izveidojot valdības un institūciju sociālās mijiedarbības modelus, lai radītu sociālo vērtību, izmantojot politiskas, tiesiskas un institucionālas reformas (makro) (Bonifacio, 2014).

Sociālo problēmu risināšanā ieinteresētās puses kopā izstrādā labākus risinājumu variantus, generējot idejas, izveidojot prototipus un izmēǵinot tos praksē. İstenošanas gaitā risinājums tiek uzlabots vai modificēts, lai sasniegtu tā ilgtspēju. Pēc tam jaunā prakse tiek paplašināta un attīstīta, dažreiz atkārtojot to vienā vai vairākās vietās un iesaistot vairāk cilvēku sociālās inovācijas procesos (Murray et al., 2010; The Young Foundation, 2012a, 2012b).

Tāpēc šì pētījuma loǵika un sociālo inovāciju projektu intervēšanas materiālu izstrāde Latvijā tika balstīta uz šādiem četriem posmiem:

1) sociālo problēmu analīze sabiedrībā un aktuālāko problēmu noteikšana,

2) sociālo problēmu efektīvākā risinājuma kopradīšana un prototipa izveidošana,

3) projekta īstenošana,

4) jaunās sociālās prakses paplašināšana un plašākas sabiedrības iesaistīšana sociālās inovācijas procesos.

\section{Sociālajā inovācijā ieinteresētās puses}

Zinātniskā literatūra atkarībā no projektu īpatnībām un risināmajām problēmām fokusējas uz dažādām sociālajā inovācijā iesaistītajām vai ieinteresētajām pusēm. Izprast, kas ir ieinteresētās personas, ir sarežgìts uzdevums, jo sociālā inovācija ir saistīta ar dažādām nozarēm un sabiedrībai nozīmīgām jomām, turklāt šīs nozares bieži vien pārklājas un mijiedarbojas savā starpā (European Union, 2012b; Davies \& Simon, 2013a; Alegre \& Berbegal-Mirabent, 2016). Dažādas pieejas akcentē atšķirīgus sociālās inovācijas aspektus, piemēram, mērḳus, modeḷus, rīkus, risinātās problēmas, rezultātus un galvenos dalībniekus. Analīze atklāja šādus sociālās inovācijas dalībniekus:

- sociālie inovatori, t. i., fiziskas vai juridiskas personas, kuras apvieno idejas, resursus un instrumentus, lai uzsāktu un īstenotu sociālās inovācijas projektus (European Union, 2012b; Lee, 2017; Seyfang \& Smith, 2007);

- sociālo inovatoru gimenes locekḷi un draugi (European Union, 2012b; Altuna et al., 2015; Alegre \& Berbegal-Mirabent, 2016); 
- citas personas, kuras nepieder pie sociālo inovatoru gimenes locekḷiem un draugiem (Hernandez \& Cormican, 2016; Altuna et al., 2015; Lee, 2017);

- mērkgrupas, t. i., personas, kuras gūst labumu no sociālās inovācijas projektiem (Bund et al., 2015);

- valsts iestādes vai organizācijas (Russon Gilman, 2017; Benneworth \& Cunha, 2015; European Union, 2012b; Alegre \& BerbegalMirabent, 2016; Altuna et al., 2015);

- pašvaldības iestādes vai organizācijas (Alegre \& Berbegal-Mirabent, 2016; Bund et al., 2015; Lee, 2017; Seyfang \& Smith, 2007);

- uznēmumi (Hernandez \& Cormican, 2016; Benneworth \& Cunha, 2015; European Union, 2012b; Altuna et al., 2015; Alegre \& Berbegal-Mirabent, 2016; Lee, 2017);

- nevalstiskās organizācijas (Altuna et al., 2015; Alegre \& BerbegalMirabent, 2016; Seyfang \& Smith, 2007);

- izglītības iestādes (Benneworth \& Cunha, 2015; Altuna et al., 2015);

- ES institūcijas vai organizācijas (European Union, 2012b; Bund et al., 2015).

Šì ieinteresēto pušu klasifikācija veidoja pamatu intervijas materiālu izstrādei, kā arī ieinteresēto pušu iesaistei sociālās inovācijas procesu novērtēšanas sistēmā.

\section{Sabiedrības finansiālā iesaistī̌̌anās sociālajā inovācijā}

Sabiedrības iesaiste sociālajā inovācijā izpaužas kā (1) informācijas un resursu nodrošināšana, (2) problēmas risināšana un (3) svarīgu lēmumu pien,emšana un ietekmēšana (Davies \& Simon, 2013b). Tika atzìts, ka ieinteresēto personu iesaiste sociālās inovācijas procesos attiecas uz vinu, finansiālo, organizatorisko un informatīvo atbalstu sociālo problēmu radošā risinājuma īstenošanā.

Sociālo inovāciju atbalsta ES struktūrfondi - Eiropas Sociālais fonds (ESF), Eiropas Reǵionālās attīstības fonds (ERAF) un Kohēzijas fonds -, lai veicinātu programmas un iniciatīvas, kā arī dotu iespēju iedzīvotājiem un organizācijām risināt sociālos jautājumus. Citi sociālās inovācijas finansējuma avoti ir sociālās bankas, privātie investīciju fondi, sociālie investīciju fondi un riska filantropijas fondi (European Union, 2012b). Kolektīvas finansēšanas platformas var būt viens no sociālās inovācijas finansēšanas veidiem (Davies \& Simon, 2013b), ko nosaka sociālās inovācijas daba tikt iniciētai no lejas uz augšu (bottom-up), iesaistot plašus sabiedrības slān,us. Sociālās inovācijas finansēšanā būtiska loma ir pašvaldībām, jo tās ierosina tādus ilgtermiṇa projektus, kuri ir vislabāk piemēroti vietējām vajadzībām. Tāpēc pašvaldības ir atzìtas par izškkirošiem iniciatoriem un ilgtspējīgas sociālās inovācijas virzītājiem 
(Bund, 2015). Pašvaldības pārrauga sociālās inovācijas programmas un strādā pie likumdošanas, kas nodrošina līdzekḷu piesaisti no valdības budžetiem vai no sociālā finansējuma (Lee, 2017). Finansiālo atbalstu nodrošina arī universitātes, kuras iegulda aktivitātēs, kas veicina sociālo inovāciju testēšanu vai uzlabošanu un inovatīvu pakalpojumu sniegšanu (Benneworth \& Cunha, 2015).

\section{Sabiedrības informatīvā iesaistīšanās sociālajā inovācijā}

Ieinteresēto pušu informatīvā iesaiste sociālās inovācijas procesos bieži vien ir nepieciešama, lai izprastu un atklātu sarežǵìtas vajadzības un apkopotu idejas jauniem un labākiem risinājumiem. Vislabāk šo problēmu būtību spēj formulēt paši pilsoṇi, jo viṇi saskaras ar tām, bieži kḷūstot par novatorisku ideju avotu (Davies \& Simon, 2013b). Universitātēm ir zināšanu sniedzēja loma, jo tās informē sabiedrību par esošajām zināšanām vai veido jaunas, kā arī sadarbojas ar sociālajiem partneriem, lai kopīgi radītu jaunas sociālo inovāciju veicinošas zināšanas. Universitātes sniedz arī padomus sociālajiem inovatoriem par to, kā vislabāk piekḷūt ārējiem zināšanu resursiem vai kas varētu palīdzēt vinniem (Benneworth \& Cunha, 2015). Visspēcīgākais informācijas sniegšanas aspekts sociālajā inovācijā ir saistīts ar sociālajiem tīkliem, kuri realizē dažādas darbības tiešsaistē, aktīvi vadot un izplatot sabiedrības viedokli, izmantojot jaunās platformas dialogam un zināšanu apmaiṇai tiešsaistes kopienās, kas l̦oti strauji paplašinās (Lee, 2017).

\section{Sabiedrības organizatoriskā iesaistīšanās sociālajā inovācijā}

Kā apgalvo Deiviss un Saimons (Davis \& Simon, 2013b), sabiedrība sniedz organizatorisko atbalstu sociālajai inovācijai vairākos veidos dažādos tās īstenošanās posmos: agrīnās stadijās - analizējot un palīdzot labāk izprast vajadzības vai apkopojot idejas jaunu un labāku risinājumu atrašanai; vēlākos posmos - risinot problēmas, kopīgi izstrādājot procesus un pieñemot svarīgus lēmumus.

Izšķirošu organizatorisko lomu spēlē pašvaldības, kuras izveido starpniekorganizācijas un sadarbības tīklus, kas atvieglo sadarbību starp valdību un uzṇēmumiem, kā arī atbalsta vietējos sociālos inovatorus un pārṇem sociālās inovācijas projektus, lai veicinātu vietējo pašpārvaldi, tādējādi atjaunojot vietējo ekonomiku un kopienas (Lee, 2017). Organizatorisko atbalstu sociālajai inovācijai sniedz arī izglìtības iestādes. Piemēram, universitātes savas telpas, tajā skaitā birojus, bibliotēkas un laboratorijas, dara pieejamas sociālās inovācijas īstenošanai un palīdz pārliecināt trešās puses gan par sociālās inovācijas nozīmīgumu sabiedrības attīstībā, gan arī - vai ieguldīt savus līdzekḷus sociālajā inovācijā (Benneworth \& Cunha, 2015).

\section{Karine Oganisjana, \\ Nicolas \\ Monge-Iriarte, \\ Konstantins \\ Kozlovskis, \\ Tālis Laizāns, \\ Svetlana Surikova \\ Sabiedrības \\ finansiālā, \\ informatīvā, \\ organizatoriskā \\ un kopējā iesaiste \\ sociālās inovācijas procesos Latvijā}


Pamatojoties uz šiem spriedumiem, sociālās inovācijas projektu intervija bija par desmit ieinteresēto pušu - sociālā inovatora, projekta mērkgrupas, valsts institūciju, pašvaldību, uznēmumu, ǵimenes un draugu, citu indivīdu, nevalstisko organizāciju, izglītības iestāžu un Eiropas Savienības institūciju - finansiālo, informatīvo un organizatorisko iesaisti sociālās inovācijas procesos.

Pēc intervijas materiālu pilotēšanas tika veikta sociālās inovācijas projektu pārstāvju intervēšana $(n=115)$. Šie projekti 15 gadu garumā tika vai arī šobrīd vēl tiek îstenoti Latgalē, Kurzemē, Vidzemē, Zemgalē un Rīgā. Intervētie pārstāvēja valsts iestādes, pašvaldības, uzñēmumus, nevalstiskās organizācijas, izglītības iestādes, Eiropas Savienības iestādes, kā arī bija atsevišḱ indivīdi, kuri īstenoja vai īsteno sociālās inovācijas projektus veselības aprūpes, sporta, izglītības, vides, lauksaimniecības, ražošanas, informācijas tehnologiju (IT) un komunikāciju tehnoloǵiju, tūrisma, izklaides, pakalpojumu, darba tirgus, sociālās politikas un citās jomās.

Intervijās bez vispārīgas informācijas par projektu mērķiem, mērķa grupām, pārstāvētajām nozarēm, budžetu, nodarbināto skaitu u. c. tika arī iegūta informācija par sociālo problēmu identificēšanas veidiem, projektu uzsākšanas cēloṇiem, būtiskajiem šksēeṣ̌liem un to pārvarēšanas mehānismiem, problēmu risināšanas ceḷa analīzi, projektā ieinteresēto pušu finansiālo, organizatorisko un informatīvo atbalstu sociālo problēmu risināšanā un to îstenošanā dzīvē, projekta finansiālo ilgtspējību un ietekmi uz sabiedrību.

Intervijās iegūto kvalitatīvo un kvantitatīvo datu kopanalīzes rezultātā tika noteikti sociālās inovācijas procesu šḳēršlı un līdzekḷi, ar kuru palīdzību tie tiek pārvarēti Latvijā. Kvantitatīvo datu statistiskās analīzes rezultātā tika noteikti Latvijas sabiedrības finansiālās, organizatoriskās un informatīvās iesaistes sociālās inovācijas procesos indeksi.

\subsection{Sabiedrības finansiālās, informatīvās, organizatoriskās un kopējās iesaistes sociālās inovācijas procesos Latvijā izpēte}

Sociālās inovācijas projektu intervijas tika veiktas klātienē vai tiešsaistes režīmā Latvijā 2016. un 2017. gadā. Projekti bija dažādos attīstības posmos. Intervija aptvēra šādas ieinteresētās puses:

- sociālais inovators (SI),

- projekta mērkgrupa (PM),

- valsts institūcijas (VI),

- pašvaldības (P), 
- uznēmumi (U),

- gimene un draugi (G̦D),

- citi indivīdi (CI),

- nevalstiskās organizācijas (NVO),

- izglītības iestādes (IZG),

- Eiropas Savienības institūcijas (ES).

Attiecībā uz sabiedrības iesaisti sociālās inovācijas procesos šì pētījuma autori definē trīs dimensijas:

- finansiālā iesaiste (FINI) - visu ieinteresēto pušu ieguldījumi, lai finansētu procesus, kas saistīti ar sociālās inovācijas uzsākšanu un īstenošanu;

- informatīvā iesaiste (INFI) - jebkurš informatīvs atbalsts, ideja vai padoms no jebkuras ieinteresētās puses, lai veicinātu izpratni, dalītos ar informāciju un izplatītu to;

- organizatoriskā iesaiste (ORGI) - jebkuras pūles, pieskatīšana, lobēšana, darbs, vadīšana, izpildes uzraudzība un ieguldījums pasākumu īstenošanā, lai sasniegtu mērḳus jebkurā sociālās inovācijas realizācijas posmā.

Intervijas gaitā sociālās inovācijas projektu pārstāvji - sociālie inovatori - novērtēja visu ieinteresēto pušu finansiālo, informatīvo un organizatorisko atbalstu un ieguldījumu viṇu projekta îstenošanā 10 punktu skalā (10 - liels atbalsts, 0 - nav atbalsta). Šajā pētījumā par projekta mērkgrupu ir dēvēti indivīdi vai indivīdu grupas, kas guva labumu no konkrēta projekta realizēšanas. Intervijas rezultātā katram projektam tika izveidota ieinteresēto pušu finansiālās, informatīvās un organizatoriskās iesaistes (atbalsta) matrica (sk. 5. tabulu).

Rezultātu matrica ir trīs vērtību kopas, kas sagrupētas pēc līdzdalības dimensijām. Izmantojot datus no visām 115 matricām, tika aprēķināti ieinteresēto pušu finansiālās, informatīvās un organizatoriskās iesaistes sociālās inovācijas procesos indeksi. Šo indeksu ieviešanas ideja un aprēksina pieeja tika izstrādātas līdzīgi tam, kā tiek aprēķināti dažādi makroekonomiskie indikatori, piemēram:

- iepirkumu aktivitātes un rezultātu indekss (Purchasing Managers' Index), kuru radīja the Institute for Supply Management (Institute for Supply Management, 2016);

- vācu Ifo uzñēmējdarbības klimata indekss (German Ifo Business Climate Index), kuru izveidoja the Center for Economic Studies of Leibniz Institute for Economic Research at the University of Munich (CESifo Group Munich, 2016).

Sabiedrības finansiālās (Index FINI , informatīvās (Index $\left.{ }_{I N F I}\right)$ un organizatoriskās (Index $\left.{ }_{O R G I}\right)$ iesaistes sociālās inovācijas procesos indeksi tika aprēksināti, izmantojot formulas: 
leinteresēto pušu finansiālā, informatīvā un organizatoriskā atbalsta matrica

\begin{tabular}{|c|c|c|c|c|c|c|c|c|c|c|c|}
\hline & \multicolumn{10}{|c|}{ leinteresētās puses } \\
\hline & & SI & PM & VI & $\mathbf{P}$ & U & G̦D & $\mathrm{Cl}$ & NVO & IZG & ES \\
\hline \multirow{3}{*}{ 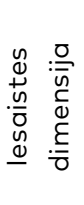 } & FINI (finansiālā iesaiste) & $f_{1}$ & $f_{2}$ & $f_{3}$ & $f_{4}$ & $f_{5}$ & $f_{6}$ & $f_{7}$ & $f_{8}$ & $f_{9}$ & $f_{10}$ \\
\hline & INFI (informatīvā iesaiste) & $i_{1}$ & $i_{2}$ & $i_{3}$ & $i_{4}$ & $i_{5}$ & $i_{6}$ & $i_{7}$ & $i_{8}$ & $i_{9}$ & $i_{10}$ \\
\hline & ORGI (organizatoriskā iesaiste) & $\mathrm{O}_{1}$ & $\mathrm{O}_{2}$ & $\mathrm{O}_{3}$ & $\mathrm{O}_{4}$ & $O_{5}$ & $O_{6}$ & $\mathrm{O}_{7}$ & $\mathrm{O}_{8}$ & $O_{9}$ & $O_{10}$ \\
\hline
\end{tabular}

Avots: autori, 2017

$$
\begin{aligned}
& \operatorname{Index~}_{F I N I}=\frac{1}{n z} \sum_{j=1}^{n} \sum_{i=1}^{z} f_{i, j} \\
& \operatorname{Index~}_{I N F I}=\frac{1}{n z} \sum_{j=1}^{n} \sum_{i=1}^{z} i_{i, j} \\
& \text { Index }_{\text {ORGI }}=\frac{1}{n z} \sum_{j=1}^{n} \sum_{i=1}^{z} o_{i, j}
\end{aligned}
$$

kur

$n$ - intervēto projektu kopskaits $(n=115)$;

$z$ - ieinteresēto pušu kopskaits $(z=10)$.

Katras ieinteresētās puses $s$ atbalsts tiek noteikts pēc formulas:

$$
\text { Index }_{s}=\frac{1}{3 n} \sum_{i=1}^{n}\left(f_{s, i}+i_{s, i}+o_{s, i}\right) .
$$

Lai novērtētu sabiedrības vispārējo iesaistīšanos sociālās inovācijas procesos Latvijā, ngemot vērā visu ieinteresēto pušu atbalstu visās trīs dimensijās, autori iesaka aprēķināt kopējo indeksu (AIndex - aggregate index), kas tiek raksturots kā lielais vidējais rādītājs (grand mean):

$$
\text { AIndex }=\frac{1}{n p z} \sum_{m=1}^{n} \sum_{j=1}^{p} \sum_{i=1}^{z} \operatorname{score}_{j, i}^{m}
$$

kur $p$ - iesaistes dimensiju kopskaits $(p=3)$.

Šo apkopoto indeksu var vēl tālāk attīstīt gadījumā, ja ir jāṇem vērā jaunas iesaistīšanās kategorijas, piemēram, projekta lielums, nozare vai ekonomikas nozare, geogrāfiskās īpašības utt. 


\section{Pètījuma izlases raksturojums un konteksts}

Tā kā sociālā inovācija ir relatīvi jauna parādība Latvijas sabiedrībā, bija liels izaicinājums atrast atbilstošus projektus, kurus pēc pazīmēm varētu saukt par sociālās inovācijas projektiem. Laika periodā no 2016. gada oktobra līdz 2017. gada aprīlim tika intervēti 115 sociālās inovācijas projektu iniciatori/pārstāvji (sociālie inovatori). Projekti bija dažādos attīstības posmos. Daži no tiem (28,7 \%) savu darbību līdz intervijas laikam bija jau beiguši. Bija arī sociālās inovācijas projekti (3,5 \%), kuru darbības ilgums nesasniedza pat vienu pilnu gadu (sk. 6. tabulu).

To projektu ilgums, kuru pārstāvji tika intervēti (kopējais šādu projektu skaits veidoja $66,90 \%$ ), galvenokārt bija gads $(21,7 \%)$ līdz četri gadi $(10,4 \%)$. Tikai 5,3 \% no visiem projektiem to dzìves ilgums pārsniedza 10 gadus (sk. 6. tabulu).

Sociālās inovācijas projektus galvenokārt īstenoja nevalstiskās organizācijas (47,8 \%), uzñēmumi (18,3 \%) un pašvaldību iestādes vai organizācijas (15,7 \%). Izglītības iestādes (2,6 \%), valsts institūcijas $(1,7 \%)$ un privātpersonas $(0,9 \%)$ retāk iniciēja sociālās inovācijas projektus, kas netieši liecina par šo iestāžu zemāku aktivitāti sociālās inovācijas procesos Latvijā.

Lielākā daḷa (55,7 \%) sociālās inovācijas projektu nodarbināja mazāk nekā 10 cilvēkus $(n<10) ; 26,1 \%$ no projektiem tika īstenoti mazos uzñēmumos $(n<50), 9,6 \%$ - vidējos uzn,ēmumos $(n<250)$, un $8.7 \%$ - lielos uzñēmumos $(n>250)$.

Projekti aptvēra dažādas darbības jomas: izglītību (42,6\%), tūrismu, izklaidi un atpūtu (24,3\%), sociālo aprūpi (14,8\%), vidi un ekologiju (14,8\%), veselības aprūpi $(13,8 \%)$, sportu $(9,6 \%)$, labdarību $(8,7 \%)$, kultūru un mākslu (7,8 \%), IKT un citas tehnologijas $(4,3 \%)$, ražošanu $(3,5 \%)$, lauksaimniecību $(1,7 \%)$ un citas nozares $(11,3 \%)$. Daži projekti integrēja divas vai trīs nozares; šādos gadījumos sociālās
Karine Oganisjana,

Nicolas

Monge-Iriarte,

Konstantins

Kozlovskis,

Tãlis Laizāns,

Svetlana Surikova

Sabiedrības

finansiālā,

informatīvā

organizatoriskā

un kopējā iesaiste

sociālās inovācijas procesos Latvijā

6. tabula

Projektu ilgums intervijas sākumā

\begin{tabular}{lccccccccccccccc}
\hline $\begin{array}{l}\text { Projektu } \\
\text { ilgums } \\
\text { (pilni gadi) }\end{array}$ & 0 & 1 & 2 & 3 & 4 & 5 & 6 & 7 & 8 & 9 & 10 & 11 & 13 & 14 & 19 \\
\hline $\begin{array}{l}\text { Projektu } \\
\text { skaits }\end{array}$ & 4 & 25 & 24 & 16 & 12 & 6 & 5 & 8 & 3 & 5 & 1 & 3 & 1 & 1 & 1 \\
\hline $\begin{array}{l}\text { Procenti } \\
(\%)\end{array}$ & 3,5 & 21,7 & 20,9 & 13,9 & 10,4 & 5,2 & 4,3 & 0,9 & 2,6 & 4,3 & 0,9 & 2,6 & 0,9 & 0,9 & 0,9 \\
\hline
\end{tabular}

Avots: Oganisjana, Surikova, Kozlovskis \& Svirina, 2018: 461. 
inovācijas projektiem tika piedāvāts norādīt vairāk nekā vienu jomu. Tas ir iemesls, kāpēc visu minēto jomu procentuālais daudzums pārsniedz $100 \%$.

Intervēto sociālo inovāciju projektu mērḳa grupas bija bērni un jaunieši (53,9 \%), cilvēki ar īpašām vajadzībām (27,8 \%), seniori $(27,0 \%)$, daudzbērnu ǵimenes (24,3\%), bezdarbnieki $(15,7 \%)$ un citi $(55,7 \%)$; dažiem projektiem bija vairākas mērkgrupas.

No aptaujātajiem 115 projektu pārstāvjiem 78 (67,8 \%) projektu respondenti atzina, ka projektos bija piedalījušies brīvprātīgie. Lielākā respondentu daḷa (59,1 \%) apgalvoja, ka ir uzsākuši projektus, lai atrisinātu sabiedrības aktuālas problēmas, savukārt tikai 21,7 \% intervēto saskatīja interesantas idejas, kuras motivēja viṇus uzsākt sociālās inovācijas projektus; pārējie 19,1 \% norādīja uz dažiem citiem iemesliem.

Galvenie šḳēršlı sociālajai inovācijai tika minēti finansējuma trūkums $(39,1 \%)$, pasivitāte sabiedrībā (31,3\%), administratīvie un birokrātiskie šķēršlı (31,3 \%), sabiedrības atvērtības trūkums citu cilvēku pieredzei un sadarbībai (14,8 \%), valsts politikas un tiesiskā regulējuma par sociālo inovāciju trūkums (13\%), pasivitāte un zems ieinteresēto personu atbalsts $(12,2 \%)$, pieredzes trūkums sociālās inovācijas projektu realizēšanā $(11,3 \%)$, nepieciešamās informācijas pieejamības trūkums (11,3 \%) un citi šksēršli (18,3 \%). Tikai 12,2 \% respondentu uzskatīja, ka projektu īstenošanā viṇiem nebija nekādu šḳēršlu. Dažu projektu pārstāvji minēja vairāk nekā vienu šksērsli, tādēḷ visu šksēršḷu procentuālais daudzums ir lielāks par $100 \%$.

Analizējot galvenās problēmas risinājuma gaitu un stilu, respondenti secināja, ka problēmu atrisināja (1) projekta grupa pati $(23,5 \%)$, (2) projekta grupa sadarbībā ar visām ieinteresētajām pusēm $(20,9 \%)$, (3) projekta grupa sadarbībā ar mērḳa grupu (14,8 \%), (4) projekta grupa sadarbībā ar ārējiem indivīdiem un/vai organizācijām $(12,2$ \%), (5) mērḳa grupa projekta grupas vadībā (4,3 \%) un (6) citā veidā $(6,1 \%)$.

Uz jautājumu, vai projekti ir bijuši finansiāli ilgtspējīgi un neatkarīgi (self-sustainable), 36,5 \% respondentu atbildēja pozitīvi, 37,4 \% uzskatīja, ka tie bija dal̦ēji finansiāli neatkarīgi, 16,5 \% atbildēja noliedzoši, un 9,6\% sniedza citas atbildes. Atbildēs uz uzdoto jautājumu par projektu prakses izplatīšanu Latvijā atklājās, ka 11,3 \% sociālās inovācijas projektu tika atkārtoti pilsētas/novada līmenī, 2,6 \% - regiona līmenī, 18,3 \% - nacionālajā līmenī, un 18,3 \% - starptautiskā līmenī. Tomēr $17,4 \%$ respondentu atzina, ka projekts netika izplatīts. Gandrīz viena trešdal̦a respondentu (32,2 \%) nebija informēti par savas prakses tālāko attīstību. 
Lielākai dal̦ai projektu $(90,4 \%)$, par kuriem intervijās dalījās to pārstāvji, bija plānots turpināt sociālās inovācijas ideju īstenošanu, bet 9,6 \% nebija šāda nodoma.

\section{Pētījuma rezultāti un to interpretācija}

Sabiedrības iesaistīšanās sociālās inovācijas procesos dinamika Latvijā, ko raksturo ieinteresēto pušu finansiālās, informatīvās un organizatoriskās iesaistes trīs indeksi (sk. 7. attēlu), tika veidota, pamatojoties uz aprēksiniem pēc formulām (1), (2) un (3). Šī dinamika balstās uz 2016.-2017. gadā veiktajām respondentu intervijām, kurās bija novērtēti arī uz to brīdi jau pabeigtie projekti.

Kā redzams 7. attēlā, informatīvie un organizatoriskie ieguldījumi ir savstarpēji cieši saistīti, savukārt finansiālajai līdzdalībai gadu gaitā ir tendence samazināties. Šì tendence ir konstatēta, arī aprēksinot korelācijas koeficientus (0,86 starp organizatorisko un informatīvo iesaisti) (sk. 7. tabulu).

Aprēksinot un analizējot visus indeksus (sk. 7. attēlu), tika secināts, ka Latvijas sabiedrībai nav raksturīgs augsts iesaistes sociālās inovācijas procesos līmenis, jo:

- finansiālās iesaistes indekss $0,88<\operatorname{Index}_{F I N I}<4,10$;

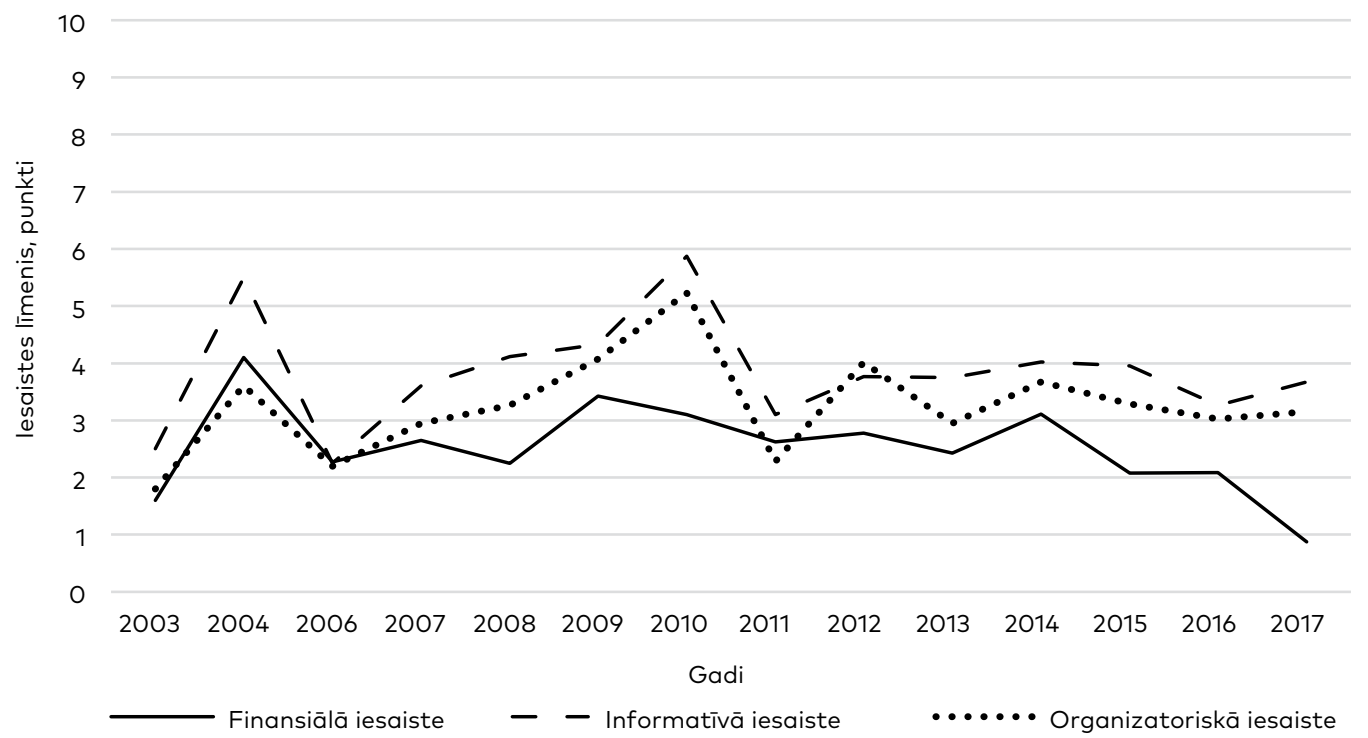

Avots: Oganisjana, Surikova, Kozlovskis \& Svirina, 2018: 464.

7. attēls. Sabiedrības finansiālās, informatīvās un organizatoriskās iesaistes sociālās inovācijas procesos dinamika Latvijā, projektu kopskaits $n=115$.

Svetlana Surikova
Karine Oganisjana,

Nicolas

Monge-Iriarte,

Konstantins

Kozlovskis,

Tãlis Laizāns,

Sabiedrības

finansiālā,

informatīiō,

organizatoriskā

un kopējā iesaiste

sociālās inovācijas procesos Latvijā 
Finansiālās, informatīvās un organizatoriskās iesaistes sociālajā inovācijā korelācijas matrica

\begin{tabular}{lccc}
\hline & $\begin{array}{c}\text { Finansiālā } \\
\text { iesaiste }\end{array}$ & $\begin{array}{c}\text { Informatīvā } \\
\text { iesaiste }\end{array}$ & $\begin{array}{c}\text { Organizatoriskāa } \\
\text { iesaiste }\end{array}$ \\
\hline Finansiālā iesaiste & 1 & & \\
\hline Informatīvā iesaiste & 0,62 & 1 & 1 \\
\hline Organizatoriskā iesaiste & 0,51 & 0,86 & \\
\hline
\end{tabular}

Avots: Oganisjana, Surikova, Kozlovskis \& Svirina, 2018: 464.

- informatīvās iesaistes indekss 2,25 < $\operatorname{Index}_{I N F I}<5,87$;

- organizatoriskās iesaistes indekss 1,80< Index $_{O R G I}<5,23$.

Tātad sociālās inovācijas procesos ieinteresētās puses atbalstīja projektus vairāk informatīvi un organizatoriski nekā finansiāli: Index $\operatorname{liNI}_{F I}<$ Index $_{O R G I}<$ Index $_{I N F I}$.

Saistībā ar sociālās inovācijas procesos ieinteresēto pušu ieguldījumu Latvijā ir viens līderis - paši sociālie inovatori. Tas nozīmē, ka sociālie inovatori izmanto vai veido savus finanšu avotus (sk. 8. attēlu), sniedz vispiemērotāko informatīvo bāzi citām ieinteresētajām pusēm (sk. 9. attēlu) un veic galvenās organizatoriskās darbības (sk. 10. attēlu).
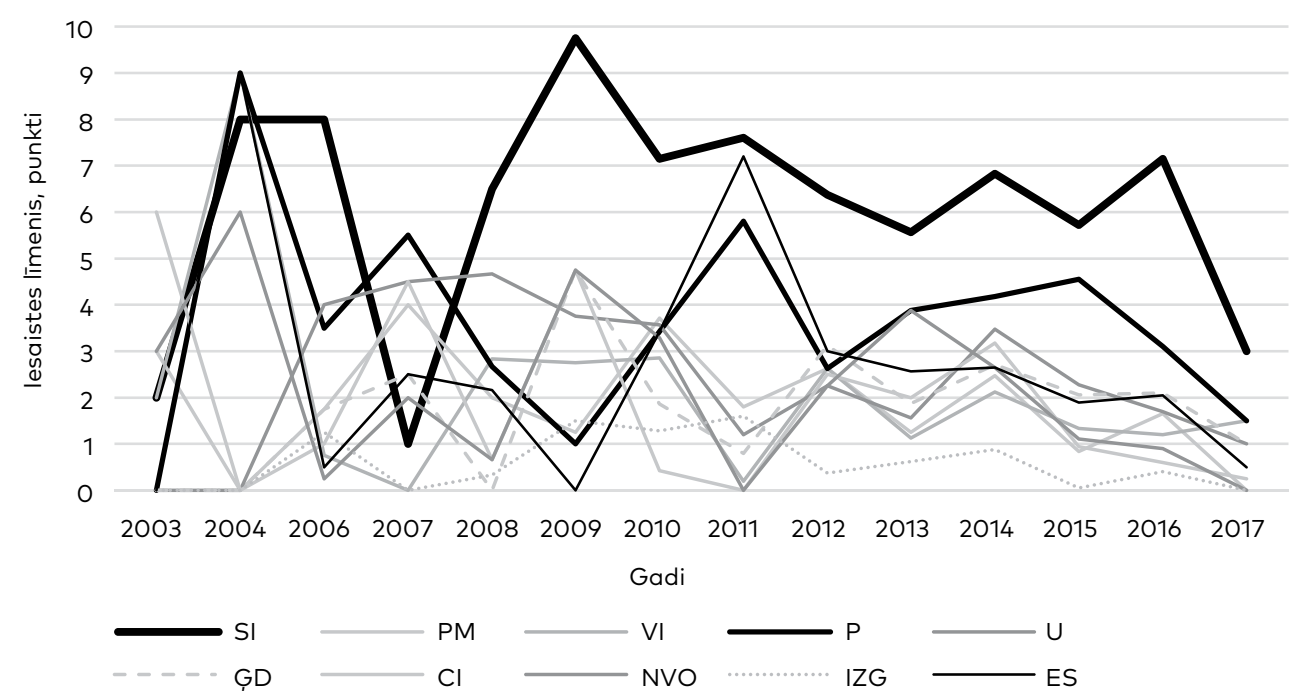

Avots: Oganisjana, Surikova, Kozlovskis \& Svirina, 2018: 465.

8. attēls. leinteresēto pušu finansiālās līdzdalības dinamika sociālās inovācijas procesos, projektu kopskaits $n=115$. 
Statistiski analizējot intervijās iegūtos kvantitatīvos datus, tika Kozlovskis,

Tālis Laizāns, noteikti sabiedrības finansiālās, organizatoriskās un informatīvās iesaistes sociālās inovācijas procesos Latvijā indeksi un analizēta sabiedrības iesaistes dinamika pēc gadiem (2003-2017), kā arī noteikti vidējie indeksi (sk. 8. tabulu).

Arī 8. tabulā redzams, ka visvairāk sociālās inovācijas projektu īstenošanā ieguldīja paši sociālie inovatori (SI), gan risinot dažādus organizatoriskos jautājumus (Index $\operatorname{XRGI}=8,58$ ), gan meklējot un nodrošinot nepieciešamo informāciju (Index $\left.\operatorname{INFI}_{I N}=8,51\right)$, gan arī ieguldot pašu finanses dažādos projektu posmos (Index $\operatorname{IINI}=6,04)$.

Sociālos inovatorus finansiāli visvairāk atbalstīja pašvaldības (Index$\left.F_{F I N I}=3,62\right)$, ES institūcijas (Index $\operatorname{IINI}_{1}=2,67$ ) un uzñēmumi $\left(\operatorname{Index}_{F I N I}=2,42\right)$. Savukārt informatīvo un organizatorisko atbalstu sociālie inovatori visvairāk saṇēma no projektu mērksgrupām (Index $\operatorname{INFI}_{I}=4,85$; Index $_{O R G I}=$ $3,56)$, pašvaldībām (Index ${ }_{I N F I}=4,33$; Index $\left._{O R G I}=3,50\right)$, ǵimenēm un draugiem (Index ${ }_{I N F I}=3,75$; Index $\left._{O R G I}=3,59\right)$.

Tātad var secināt, ka pašvaldības ir tās organizācijas, kuras sniedz vislielāko atbalstu sociālajiem inovatoriem ideju īstenošanai Latvijā. Izglītības iestādēm ir pasīva loma sociālās inovācijas procesos - tās vairāk ierobežojas ar informatīvo atbalstu teorētiskajā līmenī.

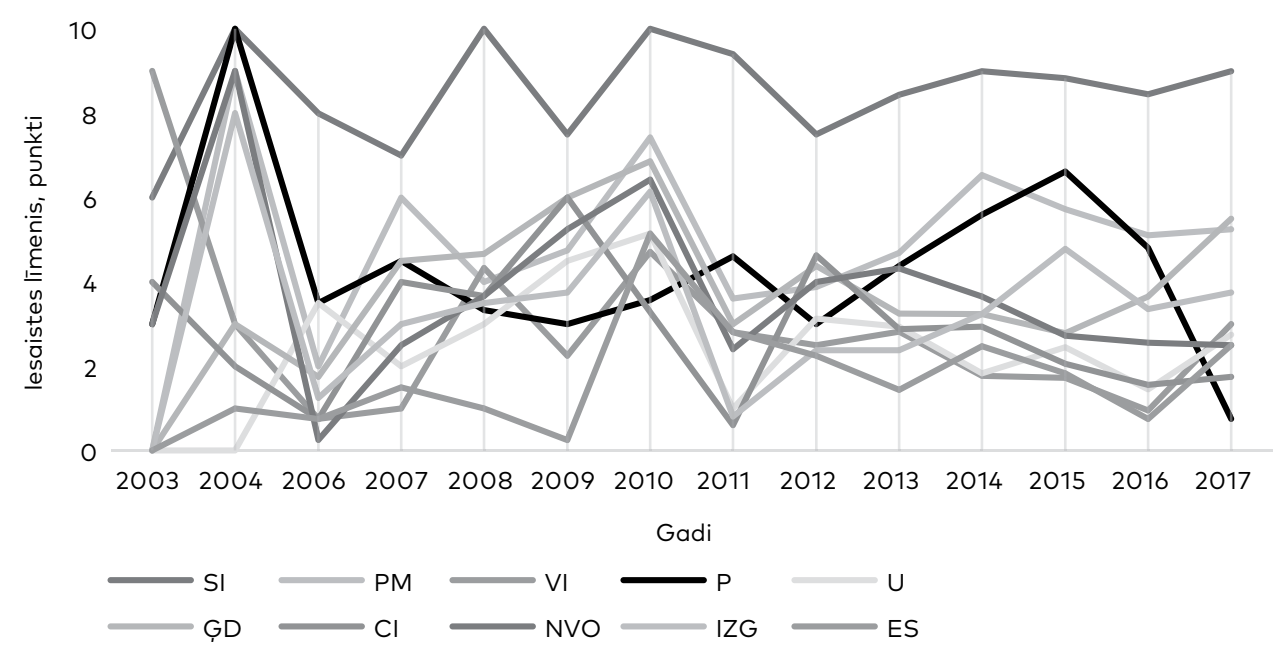

Avots: Oganisjana, Surikova, Kozlovskis \& Svirina, 2018: 465.

9. attēls. leinteresēto pušu informatīvās līdzdalības dinamika sociālās inovācijas procesos, projektu kopskaits $n=115$. 


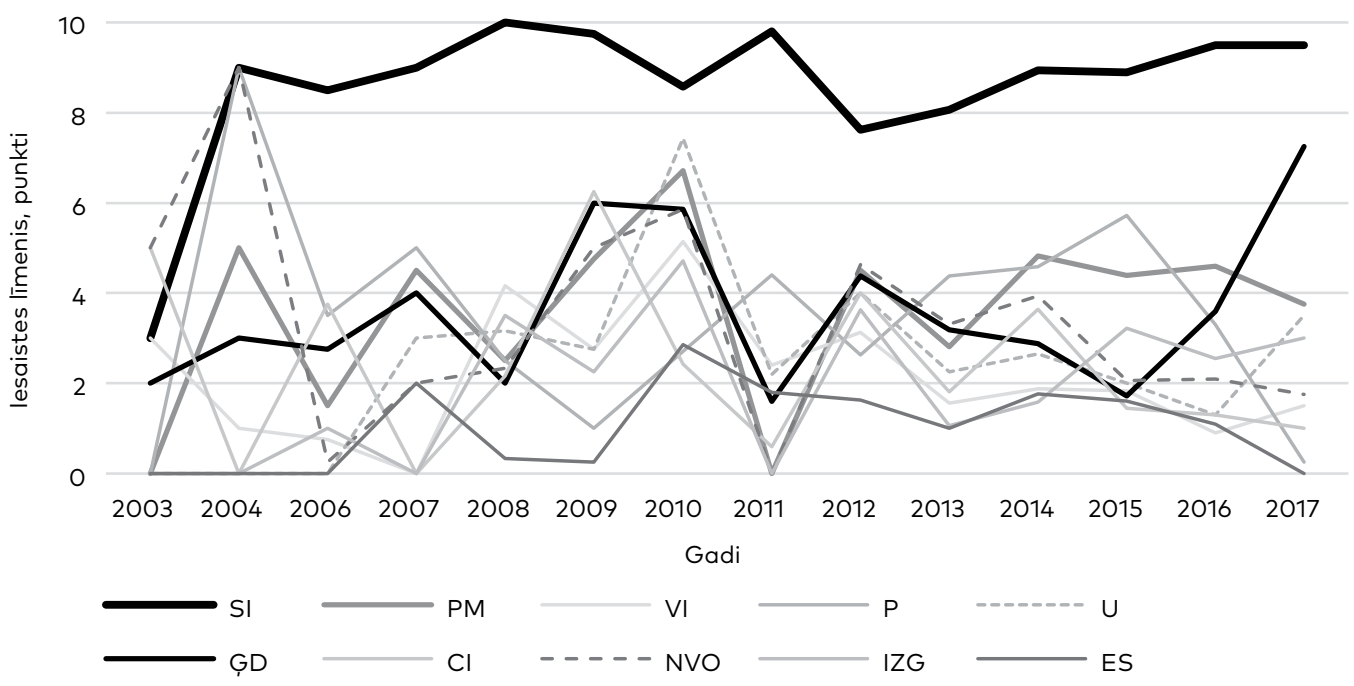

Avots: Oganisjana, Surikova, Kozlovskis \& Svirina, 2018: 466.

10. attēls. leinteresēto pušu organizatoriskās iesaistīšanās dinamika sociālās inovācijas procesos, projektu kopskaits $n=115$.

8. tabula lesaistes sociālās inovācijas procesos indeksu vidējās vērtības (2003-2017)

\begin{tabular}{|c|c|c|c|c|c|c|}
\hline \multirow{2}{*}{ Rangs } & \multicolumn{2}{|c|}{ Finansiālā iesaiste } & \multicolumn{2}{|c|}{ Informatīvā iesaiste } & \multicolumn{2}{|c|}{$\begin{array}{c}\text { Organizatoriskā } \\
\text { iesaiste }\end{array}$} \\
\hline & $\begin{array}{l}\text { lesaistītā } \\
\text { puse }\end{array}$ & Index $x_{F I N I}$ & $\begin{array}{l}\text { lesaistītā } \\
\text { puse }\end{array}$ & Index INFI & $\begin{array}{l}\text { lesaistītā } \\
\text { puse }\end{array}$ & Index ${ }_{O R G}$ \\
\hline 1 & SI & 6,04 & SI & 8,51 & SI & 8,58 \\
\hline 2 & $\mathrm{P}$ & 3,62 & PM & 4,85 & GQD & 3,59 \\
\hline 3 & ES & 2,67 & $\mathrm{P}$ & 4,33 & PM & 3,56 \\
\hline 4 & $U$ & 2,42 & GQD & 3,75 & $\mathrm{P}$ & 3,50 \\
\hline 5 & NVO & 2,20 & NVO & 3,73 & NVO & 3,37 \\
\hline 6 & $\mathrm{VI}$ & 2,16 & IZG & 3,31 & $U$ & 2,45 \\
\hline 7 & $\mathrm{Cl}$ & 1,92 & VI & 2,90 & $\mathrm{Cl}$ & 2,39 \\
\hline 8 & PM & 1,88 & $\mathrm{Cl}$ & 2,86 & $\mathrm{VI}$ & 2,14 \\
\hline 9 & GQD & 1,75 & $U$ & 2,41 & IZG & 1,89 \\
\hline 10 & IZG & 0,59 & ES & 1,69 & ES & 1,02 \\
\hline
\end{tabular}

Avots: Oganisjana, Surikova, Kozlovskis \& Svirina, 2018: 466. 


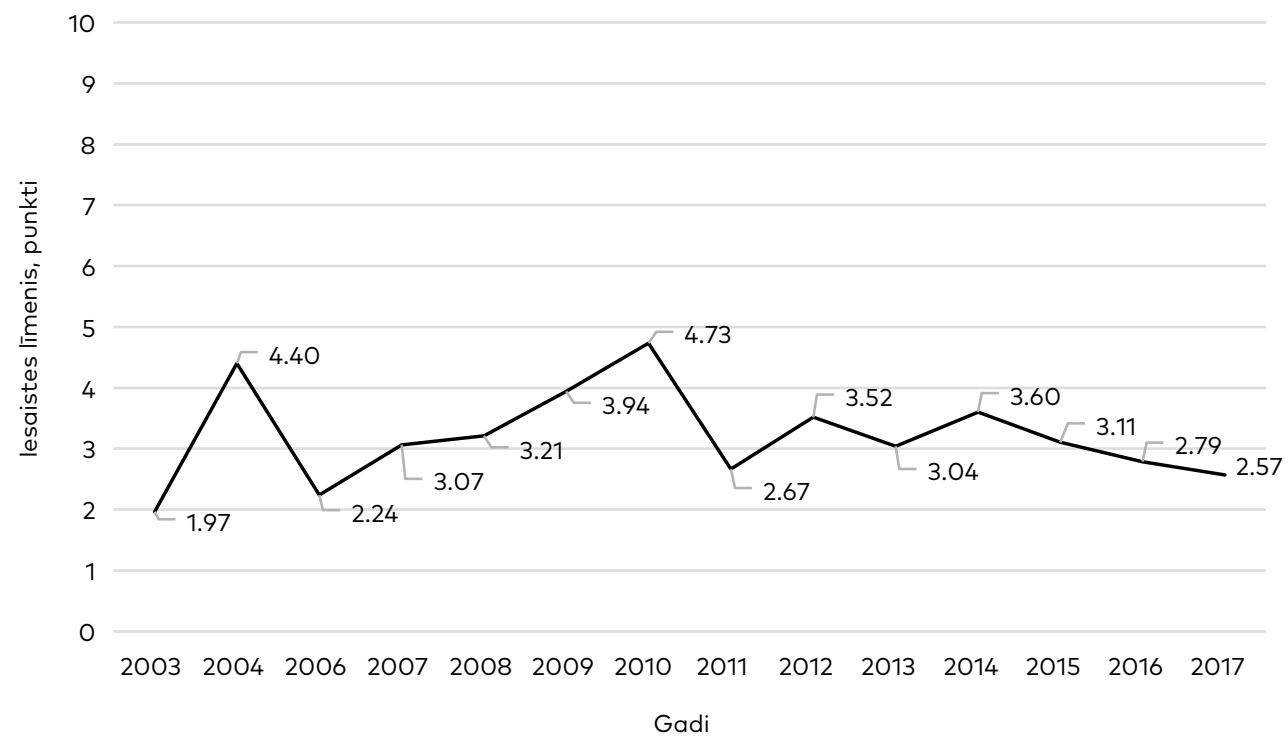

Avots: Oganisjana, Surikova, Kozlovskis \& Svirina, 2018: 467.

11. attēls. Sabiedrības iesaistes sociālās inovācijas procesos kopējais indekss Latvijā, projektu kopskaits $n=115$.

Nosakot sabiedrības iesaistes sociālās inovācijas procesos kopējo indeksu Latvijā katru gadu atsevišksi 2003.-2017. gadā (sk. 11. attēlu) un lielo vidējo rādītāju $(3,20)$ šajā periodā, tiek secināts, ka Latvijas sabiedrība ir pasīva attiecībā uz sociālās inovācijas jautājumiem.

\section{Secinājumi}

- Sociālās inovācijas procesos ar dažādu aktivitātes, atbildības un entuziasma līmeni iesaistās desmit galvenās ieinteresētās puses: sociālie inovatori, vinu gimenes un draugi, projektu mērkgrupas, valsts institūcijas, nevalstiskās organizācijas, pašvaldības, uzṇēmumi, Eiropas Savienības institūcijas, izglītības iestādes un citi indivīdi.

- Ieinteresēto pušu finansiālo, organizatorisko un informatīvo iesaistīšanos sociālās inovācijas realizācijā var novērtēt, pamatojoties uz autoru izstrādātajiem indeksiem, kuri tiek aprēḳināti, ņemot vērā sociālo inovatoru novērtējumus par ieinteresēto pušu atbalstu, ieguldījumiem un iesaisti 10 punktu skalā (sk. 1.-4. formulu). 
- Sabiedrības finansiālā, organizatoriskā, informatīvā un kopējā iesaistīšanās sociālās inovācijas procesos Latvijā nav augsta, ko var izskaidrot ar faktu, ka sociālā inovācija ir salīdzinoši jauna koncepcija Latvijas sabiedrībā, un tai pat vēl nav tiesiskā pamata. Sociālie inovatori mēgina atrisināt savas problēmas paši:

1) organizatoriskos jautājumos piesaistot gimeni un draugus, kā arī mērkgrupu;

2) iegūstot informāciju, izmantojot avotus, kurus galvenokārt nodrošina mērkgrupas, pašvaldības, giimene un draugi;

3) meklējot finansiālo atbalstu no vietējās pašvaldības un ES struktūrfondiem. Pārējo ieinteresētu pušu iesaistīšanās līmenis nav augsts (sk. 8. tabulu).

- Līdzās sociālajiem inovatoriem arī pašvaldību iestādes un organizācijas Latvijā aktīvi piedalās sociālās inovācijas realizācijā informatīvā, organizatoriskā un finansiālā līmenī, jo pašvaldības ir tieši ieinteresētas atrisināt aktuālās problēmas un radīt pozitīvas pārmaiṇas savā vidē un vietējā kopienā.

- Trīs dimensiju - finansiālo, informatīvo un organizatorisko - atbalstu sociālajiem inovatoriem Latvijā galvenokārt sniedz pašvaldības, ES institūcijas, ǵimene un draugi, kā arī projektu mērkgrupa, bet valstisko institūciju atbalsts sociālās inovācijas īstenotājiem ir zems.

Tātad sociālās inovācijas īstenošanā Latvijā galvenais spēlētājs ir pats sociālais inovators, kurš cenšas no lejas uz augšu (bottom-up) aktivizēt un konsolidēt pārējās ieinteresētās puses aktuālo sabiedrības problēmu risināšanā nenozīmīga valstisko institūciju atbalsta un nepilnīgas tiesiskās bāzes apstākḷos.

Tā kā sabiedrības iesaistīšanās sociālās inovācijas procesos visvājākā dimensija ir finansiālā iesaiste $\left(0,88<\operatorname{Index}_{F I N I}<4,10\right)$, nākamajā, 6. nodaḷā ir analizēts šis akūtais jautājums - kādi varētu būt sociālās inovācijas finansēšanas instrumenti tās veicināšanai. 


\section{SOCIĀLĀS INOVĀCIJAS \\ FINANSĒŠANAS IESPËJAS: \\ ĀRVALSTU PIEREDZES \\ APKOPOJUMS}

\section{TĀLIS LAIZĀNS}

Sociālā inovācija sākotnēji tika uzlūkota kā jaunu risinājumu un pasākumu pielietojums, iesaistot gan indivīdus, gan plašu pilsoniskās sabiedrības pārstāvniecību, lai panāktu publisko pakalpojumu pieejamību pēc iespējas plašākam sabiedrības pārstāvju lokam. Pēdējo gadu laikā pieprasījums pēc sociālās inovācijas un sociālās uzñēmējdarbības ir ieguvis sabiedrības atbalstu un izpratni arī Latvijā, neskatoties uz mūsu valsts samērā neilgo pieredzi Eiropas Savienībā, kur t. s. vecās dalībvalstis ir uzskatāmas par sociālās uzṇēmējdarbības celmlauzēm un pēdējos gados arī par nozīmīgākajām mūsdienīgu sociālās inovācijas pañēmienu attīstītājām. Tajā pašā laikā nedaudzie pētījumi un publikācijas par sociālās inovācijas iespējām un risinājumiem postsociālisma valstīs līdz šim ir snieguši tikai vispārīgu ieskatu par dažādu finansējuma instrumentu izmantošanu, kas l̦autu attīstīt sociālo inovāciju. Arī mūsu pētījums parādīja, ka zems atbilstoša atbalsta finansējuma līmenis $\left(0,88<\operatorname{Index}_{F I N I}<4,10\right)$ (sk. 5 . nodaḷu) ir viens no sociālās inovācijas attīstības izaicinājumiem. Analizējot ārvalstu pieredzi, nākas atzìt, ka problēmas ar naudas resursu piesaisti sociāla rakstura inovācijai un projektiem bieži vien ir "jānoraksta” uz zināšanu trūkumu un neprasmi izvēlēties konkrētajai situācijai atbilstošu finansējuma avotu un veidu. Šobrīd Latvijas sabiedrība un politiķi uzskata, ka ir sarežgīiti izveidot modernu alternatīvu tradicionālajiem valsts un pašvaldību pārvaldes modeḷiem, izmantojot, piemēram, sociālās inovācijas un sociālās uzṇēmējdarbības risinājumus (Pūḳis, 2012). Tomēr ir jānorāda gan uz atsevišksu ES valstu pieredzi, gan ekspertu akcentēto, ka sociālā inovācija ir "jaunas idejas (produkti, pakalpojumi, model̦i), kas tiek îstenotas, lai sasniegtu līdz šim nerealizētās sabiedrības vajadzības efektīvāk nekā 
citi alternatīvi risinājumi, un tādējādi tiek veidotas jaunas sociāla rakstura attiecības vai sadarbība" (EU/The Young Foundation, 2010:18). Ārvalstu un ES pieredze sniedz apstiprinājumu tam, ka sociālā inovācija l’oti bieži kḷūst par stimulu turpmākai uzṇēmējdarbības idejas attīstībai un komerciāla rezultāta sasniegšanai (EC, 2017: 42, 46, 48).

Līdz šim pazīstamākie sociālās inovācijas finansēšanas instrumenti gan Latvijā, gan ES ir valdības atbalsta finansējums (granti), subsīdijas un ziedojumi, nodokḷu atlaides, kā arī privātā sektora uzṇēmēju iesaistǐšanās speciālos valsts vai pašvaldības iepirkumos un labdarībā. Jāatzīst, ka mūsu valstī līdz šim trūkst pieredzes par tādiem finansējuma veidiem, kuri attiecas uz privātā kapitāla piesaisti, un tādiem sociālās inovācijas risinājumiem, kuri dod iespēju ieguldīt naudu ar mērksi pelnīt.

Pēc 2008. gada finanšu krīzes sabiedrība ir kḷuvusi skeptiska ne tikai attiecībā uz dažādām finanšu inovācijām, bet arī attiecībā uz tradicionālajiem finanšu instrumentiem un to drošumu. To norāda fakts, ka kredītu tirgus joprojām nav atkopies, lai arī nosacīta stabilitāte finanšu tirgos ir jau veselu desmitgadi. Nozares eksperti uzsver, ka ir svarīgi atjaunot ticību finanšu ieguldīšanas pakalpojumiem, radīt jaunu pieeju, paplašināt digitālo inovāciju visplašākā spektra finanšu pakalpojumu jomā, tajā skaitā arī sociālās inovācijas un sociālās uzṇēmējdarbības projektos (Bušèvica et al., 2012).

Jānorāda, ka no sagaidāmā rezultāta viedokḷa sociālās investīcijas ir jāvērtē, sadalot tās divos novērtējuma līmeṇos - finanšu un sociālajā. Par to, kā izmērīt un novērtēt finanšu rezultātu, pārsvarā gadījumu pretrunas neveidojas, jo var tikt izmantoti ekonomiskie kritēriji un rādītāji, piemēram, peḷna un investīciju ienesīgums. Tomēr no sociālās inovācijas galvenokārt tiek sagaidīts kāds sabiedrībai vajadzīgs ieguvums - jaunas iniciatīvas, darbavietas, specifiskas sabiedrības pārstāvju aktivitātes. Latvijā pašlaik aktuāli ir efektīvi veikt izglītības sistēmas reformu, tādēl var sagaidīt, piemēram, ka radīsies sociālā inovācija ar mērksi uzlabot vidusskolā iegūtās izglītības rezultātu. Problēma - ko un kā noteikt par šāda projekta izmērāmajiem rezultātiem? Vai vienā pašvaldībā definētie rezultāti var tikt atzìti par universāliem un tādējādi būt izmantojami citu pašvaldību un skolu projektos?

Tā kā nodaḷas mērksis ir parādīt un raksturot dažādus finanšu instrumentus, kas var tikt izmantoti sociālās inovācijas atbalstīšanā, par sociālā līmeṇa rezultāta novērtēšanas iespējām turpmāks diskurss netiks izvērsts.

Kā jau iepriekš tekstā norādīts, pašreizējā sociālās inovācijas un praktiski katra sociālā uzṇēmuma viena no nozīmīgākajām problēmām ir - kā piesaistīt investorus, kā panākt, ka sociālās inovācijas izmaksas 

jektu izaugsmi?

Vispirms jānorāda atsevišḳi specifiski apstākḷi, kas saistās ar sociālo inovāciju un tās rezultātā veidojamo projektu finansēšanu.

Kā liecina prakse, sociālās inovācijas finansēšanā nav iespējama tieša t. s. tradicionālo investoru piesaistīšana. Otrkārt - Latvijas apstākḷos nav reāli sagaidīt, ka sociālo inovāciju būs iespējams finansēt no sociālās uzṇēmējdarbības ieṇēmumiem. Tādēl, nākas atzìt, ka, lai arī ir saprotams, ka sabiedrība un uzṇēmēji gūs labumu un peḷnu no sociālā projekta, tomēr privātā kapitāla tirgus cena nel̦auj izmantot tradicionālos finansēšanas instrumentus, proti, tirgū var veidoties neatbilstība starp sagaidāmo sociālo ieguvumu un iespējamo finanšu ieguldījuma ienesīgumu, ja šis kapitāls tiktu ieguldīts komerciālos projektos vai finanšu instrumentos ${ }^{1}$. Vienkāršs skaidrojums šeit minētajam: privātās naudas aktuālā tirgus cena (kredīta vai depozīta procentu likme) ir lielāka par dividendēm vai peḷnu, kas, iespējams, tiktu iegūta, ìstenojot sociālo inovāciju.

Tajā pašā laikā arī Latvijā aktuāli kḷūst dažādi sabiedriskā labuma projekti, kas negarantē tūlītēju un augstu pel̦nu, bet ir vērtējami kā potenciāli un tirgus atdevi nodrošinoši vidējā vai ilgtermiṇa perspektīvā.

Balstoties savā pieredzē, ieskatam autors piedāvā uz vispārēja sabiedriskā labuma gūšanu orientētu potenciālo projektu piemērus:

- alternatīvo atjaunojamo enerǵijas resursu izmantošana (t. s. zal̦ā energija),

- organiskās pārtikas ražošana un tirdzniecība galvaspilsētā un regionos,

- dažādu komerciāla rakstura pakalpojumu pieejamības nodrošināšana iedzīvotājiem ar zemiem ienākumiem,

- pakalpojumu sniegšana par pazeminātu cenu (piemēram, mūžizglīî̄bas pakalpojumi).

Viena no iespējām šādu un citu projektu īstenošanai saistās ar sociālās inovācijas inkubatoru veidošanu Latvijas reǵionos. Pašreizējā situācijā šādu specifisku darbības virzienu orientētu regionālo inkubatoru priekšrocība var tikt pamatota galvenokārt ar to, ka joprojām sociālais uzñēmums spēj pastāvēt un izdzīvot, tikai pateicoties valdības subsīdijām vai turīgu personu ziedojumiem² ${ }^{2}$.

Tomēr sociālās inovācijas inkubatoru attīstība un sekmīga pastāvēšana nebūs garantēta, ja netiks apgūta prasme pielietot specifiskus

\footnotetext{
${ }^{1}$ Avotos sastopams termins "financial-social return gap", ko izmanto, lai raksturotu šo investīiju sagaidāmā rezultāta pretrunu.

2 Nav informācijas, ka Latvijā būtu izveidots un darbotos kāds labdarības fonds (charitable foundation).
} 
finanšu instrumentus, kas nodrošina no tradicionālās komercfinansēšanas atškirīgu finansēšanas struktūru.

Pēc iepazīšanās ar līdzšinējo ārvalstu pieredzi autors izdara secinājumu, ka Latvijā pastāv reālas iespējas sekmīgi pielietot dažādus, līdz šim nepielietotus finansējuma avotus un instrumentus, kas var attīstīt sociālo inovāciju un nodrošināt sociālo uznēmumu attīstību. Turpmāk tiks parādīti iespējamie finansējuma varianti un ieskicētas šiem instrumentiem raksturīgas pazìmes.

\section{Speciāls sociālais ieguldījums}

Ieguldījuma variants, kas investoram piedāvā dažādus ieguldījuma variantus ar dažādiem peḷnas nosacījumiem katram specifiskajam ieguldījumam (ṇemot vērā katra individuālā ieguldītāja prasības atkarībā no ieguldījuma termiṇa, pieprasītās peln,nas normas u. c.). Kā zināmākie šāda veida labdarības un sociālo ieguldījumu veicēji ir Kelloga fonds (W. K. Kellogg Foundation, 2018) un Rokfellera fonds (The Rockefeller Foundation, 2018).

\section{Speciāls mērḳa labdarības fonds}

Šāda mērksa labdarības fonda ieguldītāji var būt privātpersonas, valdība, pašvaldības, un tā galvenais uzdevums ir izsniegt garantiju aizdevumam, lai sociālais uzñēmums varētu iegūt bankas kredītu. Piemēram, İrijas valdība ir radījusi Sociālo inovāciju fondu, kas savukārt izveidoja speciālu mērķa fondu "Equality Fund" (SIF, 2018).

\section{Konvertējamais kredīts}

Konvertējamais kredīts, paredzot aizdotās summas konvertēšanu kapitāldaḷās, ja netiek pildīti kredītlīguma nosacījumi (piemēram, nav iespējams veikt kredīta pamatsummas atmaksu, nav iespējams veikt pamatsummas atmaksu līgumā paredzētajā termin̄ā). Peḷnu šādos līgumos iespējams sasaistīt ar organizācijas finanšu rezultātu (indeksēt). Nauda tiek aizdota sociālajam uzñēmumam, bet aizdevuma atmaksu indeksē ar komercuzṇēmuma finanšu rezultātu (tādas kapitālsabiedrības darbības rezultātu, kas ir saistīta ar šo sociālo uzṇēmumu vai sociālo projektu). Pēc šāda kreditēšanas principa darbojas "Bridges Social Entrepreneurs Fund" Anglijā (Bridges, 2018).

\section{Sociālais kopīgo ieguldijumu fonds}

Šādā fondā naudas ieguldītāji ir tikai t. s. sociālie investori. Ieguldītājiem tiek piedāvāta iespēja veidot vairākas ieguldījumu paketes. Piemēram, ja pakete paredz vislielākās dividendes, tad ieguldītājam ir jārēksinās ar vislielāko risku kā pirmajam zaudēt savu ieguldīto naudu. Šādu sociālo kopīgo ieguldījumu fondu piemēri ir "IFMR Trust" (Čenaja, 

nas fondus četros kontinentos (Bugg-Levine et al., 2010; BlueOrchard, 2018).

\section{Sociālās obligācijas (social impact bonds)}

Uz sociālo rezultātu orientētu parāda vērtspapīru (obligāciju) emisija. Šādas obligācijas pirmoreiz tika emitētas Anglijā 2010. gadā (BuggLevine et al., 2010; Kay, 2017). Ieguldītāji san,em procentu maksājumus un piedalās peḷnas sadalē, ja sociālās inovācijas projekts, piemēram, infrastruktūras projekts, tiek īstenots. Cits iespējamais šāda projekta piemērs: rehabilitācijas projekta rezultātā samazinās noziedzība, cietumsodu izcietušie neatgriežas uz likumpārkāpuma ceḷa.

Šeit uzskaitītie un ieskicētie finanšu instrumenti prasa detalizētu iespēju un risku izvērtējumu, ja kādu no tiem paredzētu izmantot sociālās inovācijas un sociālā uzṇēmuma finansēšanā Latvijā.

\section{Secinājumi}

- Latvijā ir neliela pieredze dažādu finanšu iespēju un instrumentu izmantošanā, kuri būtu pielietojami sociālās inovācijas projektu finansēšanā. Praksē nav izmantotas ārvalstīs pielietotās shēmas, kas lauj piesaistīt tādu privāto kapitālu, kurš meklē dažāda ienesīguma peḷnas iespējas.

- Pētniekiem sadarbībā ar finanšu jomas ekspertiem ir jāizvērtē dažādu finansēšanas modelu un scenāriju pielietojuma iespējamība Latvijā, n,emot vērā vietējo mikro- un makrovidi.

- Svarīgi ir izglītot sabiedrību, politikas veidotājus, investorus un citus sociālos partnerus par dažādu finanšu instrumentu izmantošanas iespējām, kā arī par riskiem.

Kādas sociālās inovācijas attīstības perspektīvas un kādus stratēǵiskos scenārijus saskata eksperti un valsts amatpersonas sociālās inovācijas veicināšanā Latvijā, ir analizēts nākamajā nodaḷā. 


\section{SOCIĀLĀS INOVĀCIJAS}

\section{VEICINĀŠANAS}

\section{SCENĀRIJI LATVIJĀ}

\section{LĀSMA LİCİTE, GUNTA GRĪNBERGA-ZĀLĪTE}

Sociālās inovācijas veicināšana ir būtiska ne tikai Latvijā, bet tā ir definēta arī kā viena no Eiropas Savienības prioritātēm, kas sekmē sabiedrības dzīves kvalitātes paaugstināšanu (European Commission, 2013), valsts ilgtspējīgu attīstību un konkurētspēju (Osburg \& Schmidpeter, 2013). Lai sekmētu sabiedrības atvērtību un aktīvu līdzdalību sociāli ekonomiskajos procesos, radoši jāattīsta esošās un jāievieš jaunas sociālās inovācijas formas, nodrošinot to darbības juridisko pamatojumu. Šie pasākumi ir saistīti ar cilvēkresursu potenciāla pilnvērtīgu izmantošanu sociālās inovācijas procesā, sociālā kapitāla, sociālās līdzdalības un uz sociālo inovāciju orientētas izglītības attīstību. Tā kā Latvijā sociālās inovācijas koncepcija ir samērā jauna un nav pietiekami pētīta, trūkst arī regulējošo likumu valsts līmenī. Lai gūtu padziḷinātu izpratni par to, kā veicināt sociālās inovācijas projektu îstenošanas aktivitāti nacionālā līmenī, pētỉjuma ietvaros tika izstrādātas un analizētas vairākas atšķirīgas sociālās inovācijas veicināšanas iespējas, kuras varētu kalpot Latvijas ekonomikas attīstības sekmēšanai.

\section{Pētījuma metodoloǵija}

Pētījumā tika definēts mērķis izstrādāt un izvērtēt sociālo inovāciju veicināšanas scenārijus Latvijas ekonomikas attīstības sekmēšanai. Šĩ mērka sasniegšanai tika noteikti divi uzdevumi:

1) izstrādāt potenciālos sociālās inovācijas attīstības scenārijus Latvijas ekonomikas attīstības veicināšanai;

2) pamatojoties uz ekspertu viedokḷiem, noteikt piemērotāko scenāriju sociālās inovācijas veicināšanai Latvijā.

Lai iegūtu pētījuma îstenošanai nepieciešamos datus, sākumā tika izmantota fokusgrupas diskusija ar uzṇēmējdarbības, izglìtības, sporta, 
komunikācijas un labdarības jomas pārstāvjiem, kam sekoja padziḷinātas individuālas intervijas ar speciāli izvēlētiem valsts un privātā sektora uzṇēmumu, Ekonomikas ministrijas un NVO pārstāvjiem.

Datu apstrādei un interpretācijai tika izmantotas scenāriju metode, hierarhiju analīzes metode un fokusgrupas diskusijas transkriptu kvalitatīvā kontentanalīze, pielietojot $A Q U A D 6$ un Nvivo programmatūras.

Pētījums tika organizēts tā, lai, pamatojoties uz fokusgrupas diskusijas dalībnieku paustajām atziṇām, varētu izstrādāt vairākus alternatīvus sociālās inovācijas attīstības scenārijus Latvijas ekonomikas veicināšanai. Savukārt, lai noteiktu piemērotāko attīstības scenāriju sociālās inovācijas attīstībai Latvijā, pētījumā tika pielietota amerikānuu zinātnieka T. Satī (Saaty) izstrādātā hierarhijas analīze (The Analytic Hierarchy Process (AHP)) (Saaty, 1977, 1994). Šì metode ir paredzēta kompleksu lēmumu pien,emšanai. Metodes būtības pamatā ir sistēmiska un hierarhiska problēmas elementu sakārtošana. Problēma pakāpeniski tiek sadalīta arvien vienkāršākās daḷās, bet šīs daḷas tiek salīdzinātas pa pāriem un novērtēta šo problēmas elementu mijiedarbības intensitātes pakāpe hierarhijā. Tā kā hierarhijas metode paredz prioritāšu noteikšanas procesā iesaistīties vienlaikus vairākiem ekspertiem, tā lıaj šajā analīzes posmā ievērot visu iesaistīto pušu intereses. Ekspertu novērtējums tiek kārtots skaitliski, izmantojot relatīvā svarīguma skalu (Saaty, 1994).

Hierarhijas analīzes metodei sarežgīitu pētniecības jautājumu analīzē ir vairākas priekšrocības. Pirmkārt, subjektīvo lēmumu pieṇemšanas process ir sistēmisks, un tā rezultātā tiek iegūti precīzi vērtējumi. Otrkārt, lēmumu pieṇēmēji saṇem detalizētu informāciju par vērtēšanas kritērijiem un relatīvo svarīguma skalu (Narasimhan, 1983). Treškārt, hierarhiju analīzes lietošanā tiek nodrošināta izpratne un saskaṇa starp lēmumu pieṇēmējiem (Harker \& Vargas, 1987).

Lai risinātu kompleksas problēmas ar vairākām mijsakarībām, pētījumos jānodrošina starpdisciplinārā pieeja un vairāku ieinteresēto pušu līdzdalība, tādējādi radot jaunas zināšanas un sekmējot dzilāāku izpratni, un rodot inovatīvākus risinājumus. Tam atbilstoša ir scenāriju metode, kas tiek izmantota situācijās, kad ir liela nenoteiktība par nākotni kompleksas sistēmas ietvaros (Bishop et al., 2007). Scenāriju metode ir piemērota arī tādēl, ka tā l̦auj samazināt subjektivitāti lēmumu pieṇemšanā, jo tiek izstrādātas dažādas iespējamās nākotnes (Van der Heijden, 2005) un scenāriju plānošanā tiek n,emti vērā dažādu ieinteresēto grupu viedokḷi (Durand, 2003; Meissner, Wulf, 2012). Projekta "Sabiedrības iesaiste sociālās inovācijas procesos Latvijas ilgtspējīgas attīstības nodrošināšanai” empīriskajā pētījumā, veidojot scenārijus par sociālo inovāciju attīstību Latvijā, tika pielietota intuitīvās loǵikas pieeja (Van der Heijden et al., 2002; Schwartz, 1996). Atbilstoši tai sociālo 
inovāciju scenāriju veidošana tika balstīta uz trīs secīgiem posmiem. Pirmajā posmā tika noteikts scenāriju analīzes mērḳis un pētījuma plašums (scope); otrajā posmā tika identificēti sociālās inovācijas attīstību noteicošie faktori (virzošie spēki) (Schwartz, 1996) vai cēlonnfaktori (Porter, 1998), bet trešajā - pamatojoties uz iepriekšējo izpēti (ietekmējošo faktoru identificēšanu un fokusgrupas rezultātiem), tika definēti un sīkāk raksturoti trīs alternatīvi scenāriji. Pēdējā posmā šie scenāriji tika nodoti ekspertu izvērtēšanai, kam sekoja Latvijas apstākḷiem viena vispiemērotākā scenārija izvēle.

\subsection{Sociālās inovācijas veicināšanas scenāriju izstrāde Latvijas apstākliem}

Pamatojoties uz diviem svarīgākajiem sociālās inovācijas veicināšanu ietekmējošiem faktoriem - iniciatīvas uzṇemšanās pār sociālās inovācijas veicināšanu un atbalsta instrumenti -, tika izvirzītas iespējamās nākotnes alternatīvas sociālās inovācijas veicināšanai Latvijā.

Tajā pašā laikā pētījumā bija būtiski arī noteikt no piedāvātajiem scenārijiem vienu vispiemērotāko sociālās inovācijas attīstībai Latvijā. Lai šo mērksi sasniegtu, sākotnēji tika noteikti vairāki atškirīgi iespējamie sociālās inovācijas attīstības scenāriji. Tie visi tika izstrādāti, pamatojoties uz fokusgrupas dalībnieku un zinātniskajā literatūrā paustajām atziṇām. Pētījuma gaitā scenāriju veidošanas pamatā tika uzstādīti divi pamatnosacījumi: iniciatīvas uzṇemšanās pār sociālās inovācijas virzīšanu un atbalsta instrumentu intensitāte sociālās inovācijas attīstībai.

Iniciativas uzṇemšanās pār sociālās inovācijas virzīšanu. Apstāklis, ka gandrīz visas sociālās problēmas ir komplicētas un savstarpēji saistītas, nosaka nepieciešamību to risināšanā iesaistīt dažādas ieinteresētās puses (Khutrakun, 2013). Sociālā inovācija bieži tiek saistīta ar indivīdiem un nevalstiskajām organizācijām, taču daudzas sociālās inovācijas tiek radītas arī uzṇēmējdarbības sektorā. Tomēr realitātē sociālo inovāciju radīšanā ir ieinteresēts arī valsts sektors, tirgus dalībnieki, dažādas sociālās kustības, organizācijas un izglītības iestādes (Bulut et al., 2013; Phills et al., 2008). Tādējādi jāsecina, ka sociālā inovācija ir būtiska visos nacionālās tautsaimniecības sektoros, kur pastāv sabiedrības neapmierinātās vajadzības. Tas nozīmē, ka iniciatīvu sociālās inovācijas attīstīšanā var uzṇemties gan valsts, gan uzṇēmēji, gan arī sabiedrības indivīdi.

Valsts kā sociālās inovācijas iniciators. Par valsts iniciētiem sociālās inovācijas piemēriem var uzskatīt jaunos likumus, piemēram, "Likumu par minimālo vecumu bērniem, kas strādā rūpnīcās un veikalos" (Minimum Age for Children Working in Factories and Stores) (McVoy, 
1940), kā arī likumus, kas stiprina dažādu sabiedrības grupu tiesības (piemēram, normatīvie akti, kas nosaka sieviešu balsstiesības) (Mulgan et al., 2007a). Par valsts iniciētu sociālo inovāciju var uzskatīt arī apdrošināšanu pret slimībām un nabadzību, sabiedrisko parku izveidi u. c. (Mulgan et al., 2007a).

Uzṇēmēji kā sociālās inovācijas iniciatori. Sociālā inovācija var tikt īstenota arī uzṇēmējdarbības sektorā (Stewart, 1981). Uzṇēmējdarbības kontekstā sociālā inovācija visbiežāk tiek saistīta ar sociālajiem uzñēmumiem, kuru prioritāte ir risināt sociālās vai vides problēmas, izmantojot uzṇēmējdarbības instrumentus (Bessant \& Tidd, 2011). Sociālie uzṇēmēji bieži izstrādā inovatīvus risinājumus, lai pārvarētu tirgus radītās nepilnības (īpaši - lai risinātu minoritāšu vai kādu konkrētu sabiedrības grupu problēmas) (Kacou, 2011; Murray et al., 2010; Evers et al., 2004) vai lai risinātu valsts problēmas sabiedrisko pakalpojumu nodrošināšanā (Leadbeater, 1997). Vairāki zinātnieki norāda, ka sociālā uzṇēmējdarbība ir vislabākais risinājums tirgus radīto nepilnību kompensēšanai, ko rada augstās darījumu izmaksas, ārējo faktoru ietekme uz godīgu cenu politiku, asimetriska informācijas plūsma starp pircēju un pārdevēju (Drayton, 2002; Nicholls \& Cho, 2006; Emerson \& Bonini, 2003). Sociālie uzñēmēji izmanto J. Šumpetera (Schumpeter, 1942) argumentu, ka ir nepieciešama uzṇēmējdarbības pieejas maiṇa, lai atrisinātu dziḷi iesakṇojušās, tradicionālās tirgus sistēmas radītās problēmas, kā rezultātā rodas preču un pakalpojumu nepietiekamība, bezdarbs un ienākumu zaudēšana noteiktām sabiedrības grupām. Šo problēmu risināšanai ir aktuāli meklēt inovatīvus risinājumus. N̦emot vērā sociālās uzñēmējdarbības būtību, sociālie uzñēmēji bieži tiek dēvēti par jaunu tirgu "aǵentiem" tajās tirgus sfērās, kuras tradicionālo privāto sektoru neinteresē.

Č. Līdbīters (Leadbeater, 1997) uzsver, ka sociālie uzñēmumi var kḷūt par nozīmīgu inovāciju, īpaši sociālo inovāciju, avotu. Piemēram, mikrokredīti (Grameen Bank) tika radīti, lai nodrošinātu finanšu resursu pieejamību tām sabiedrības grupām, kurām tradicionālās bankas nepiešḳīra aizdevumus, tādējādi būtiski uzlabojot šo cilvēku dzīves līmeni (Phills et al., 2008). "Pasaules Banka", pētot "Grameen Bankas" piemēru, atklāja, ka 5 \% no bankas aizṇēmējiem katru gadu izkḷūst no nabadzības. "Grameen Bankas" ikgadējās aptaujas liecina, ka kopumā 64 \% no aizṇēmējiem, kuri sadarbojas ar šo banku piecus gadus un ilgāk, ir izkḷuvuši no nabadzības. Mikrokredītu kustības pamatlicējs Nobela miera prēmijas laureāts profesors M. Junuss (Yunus, 2007) uzsver, ka, paplašinot izpratni par jēdzienu "uzṇēmējs", esošā kapitālisma sistēma var būtiski tikt mainīta, un tas var atrisināt daudzas sociālās un ekonomiskās problēmas brīvā tirgus apstākḷos. 
Zinātniskajā literatūrā tiek akcentēts, ka sociālie uzñēmēji rada sociālo inovāciju un pārmaiṇas dažādās jomās, tajā skaitā izglītības, veselības, vides un uzñēmējdarbības attīstībā (Haugh, 2005), kā arī inovācija var izpausties sociālā uzṇēmuma vadībā, struktūrā un stratēǵijā. Tas nozīmē, ka problēmas, kas agrāk tika uzskatītas tikai par valsts atbildību, tiek uztvertas kā iespējas uzṇēmējdarbībai. Proti, sociālā problēma var tikt pārvērsta efektīvā uzṇēmējdarbības iespējā, kas vērsta uz dzīves kvalitātes uzlabošanos - ìpaši sociāli jūtīgajām sabiedrības grupām (Certo \& Miller, 2008; Haugh, 2005).

Nevalstiskais sektors kā sociālās inovācijas iniciators. Sociālā inovācija var izpausties arī nevalstiskajā sektorā, un tās iniciatori var būt sociālās kustības, bezpeḷnas organizācijas (piemēram, biedrības un nodibinājumi) un pilsoniskās sabiedrības apvienības, kuru aktivitātes vērstas uz vietējās kopienas dzīves līmeña uzlabošanu. Zinātnieku vidū pastāv uzskats, ka indivīdi ir ideju nesēji, bet sociālās inovācijas iniciatori ir sociālās kustības vai bezpeḷnas (nevalstiskās) organizācijas. Tas izriet no apstākḷa, ka sociālās inovācijas radīšanā ir iesaistīti vairāki indivīdi un līdzīgas idejas bieži vienlaikus izplatās dažādās vietās (piemēram, vides kustība, kas palielināja informētību par ierobežotajiem planētas resursiem un aicināja uz pārmaiṇu ieviešanu; feministu kustība). Sociālo kustību ideju saknes meklējamas neapmierinātībā ar kādu sabiedrības vai vides problēmu. Sociālās kustības savā aktivitātē iesaista cilvēkus, lai tie paši risinātu problēmas, nevis gaidītu tikai uz valsts atbalstu.

Atbalsta instrumentu intensitāte. Sociālās inovācijas attīstības veicināšanā iespējami dažādi atbalsta instrumenti. Valsts var atbalstīt ar finansiāli nozīmīgiem instrumentiem - nodokḷa atvieglojumiem, grantiem, kā arī ESF finansējuma piesaisti sociālo inovāciju attīstībai. Sociàlo inovāciju attīstību var veicināt arī uzṇēmēji un sabiedrības indivīdi, izmantojot to rīcībā esošos resursus.

Līdz ar to, pamatojoties uz diviem svarīgākajiem sociālo inovāciju attīstību ietekmējošiem nosacījumiem, tika izvirzìtas trīs vienlīdz iespējamas nākotnes alternatīvas sociālo inovāciju attīstībai Latvijā:

1) sabiedrības pašiniciatīvas virzīts scenārijs - sociālā inovācija kā brīvprātīgo darbs;

2) valsts iniciatīvas virzīts scenārijs - sociālā inovācija kā valsts ilgtspējīgas attīstības veicināšanas nosacījums;

3) uzṇēmumu iniciatīvas virzīts scenārijs - sociālā inovācija kā korporatīvās sociālās atbildības būtiska sastāvdaḷa.

Sabiedrības pašiniciatīvas virzìts scenārijs: iniciatīvu pār sociālās inovācijas attīstību galvenokārt uzṇemas sabiedrības indivīdi, kurus iesaistīties pārsvarā motivē vinu kopienās neatrisinātās sociālās problēmas un/vai neapmierinātās vajadzības. Tādējādi sabiedrības indivīdi 
uztver sociālo inovāciju kā brīvprātīgo darbu savas kopienas labā, pretī nesaṇemot atlīdzību vai īpašu valsts atbalstu sociālās inovācijas virzīšanai.

Valsts līdzdalības attīstības scenārijs: galvenais iniciators sociālo inovāciju attīstības virzī̌sanā ir valsts, kas nodrošina noteiktus atbalsta instrumentus (finanšu, tiesiskos, informatīvos u. c.) sociālo inovāciju ieviesējiem un īstenotājiem. Šis scenārijs ietver arī pašvaldības atbalstu, proti, pašvaldība var sekmēt sociālo inovāciju attīstību, nodrošinot infrastruktūras vai informatīvo atbalstu. Šì scenārija īstenošana kopumā sekmē sabiedrības ilgtspējīgu attīstību, jo sociāli ekonomiskās problēmas tiek risinātas, izmantojot finanšu un citus atbalsta instrumentus sociālo inovāciju atbalstam.

Uzṇēmumu iniciētas attīstības scenārijs iekḷauj uzṇēmējus kā galvenos sociālo inovāciju virzītājus, ietverot to rīcībā esošos atbalsta instrumentus (piemēram, mentoringu). Uzṇēmēju motivācija iesaistīties sociālās inovācijas veicināšanā saistās ar sociāli atbildīga uzṇēmuma tēla veidošanu, kas paredz gan uzñēmuma iekšèjā vidē, gan ārējā vidē ar praktisku rīcību pierādīt savu vēlmi, piemēram, samazināt uzṇēmuma ražošanas procesā radīto negatīvo ietekmi uz vidi, ar saviem produktiem un pakalpojumiem veicināt sociāli vēlamus paradumus, veicināt sabiedrības integrāciju, mazināt sociāli mazaizsargāto grupu atstumtību utt.

\subsection{Sociālās inovācijas veicināšanas scenāriju izvērtējums}

Sociālās inovācijas veicināšanas scenāriju izvērtēšana tika īstenota, izmantojot hierarhijas analīzi. Lai varētu izmantot hierarhijas analīzes metodi, tika izveidota četros līmen,os sadalīta hierarhijas piramīda (sk. 12. attēlu).

Pirmajā līmenī tika definēts vispārējais mērḳis - piemērotākā scenārija izvēle sociālās inovācijas veicināšanai Latvijā.

Otrajā līmenī ir izveidotas kritēriju grupas, kuras ir ieinteresētas sociālās inovācijas veicināšanā. Kritēriju grupas tika noteiktas, uzdodot jautājumu: "Kuram/kam ir svarīgi, ka Latvijā tiek veicināta sociālās inovācijas attīstība?" N,emot vērā zinātniskajā literatūrā un fokusgrupas diskusijā izdarītās atziṇas, par galvenajām kritēriju grupām tika izvēlētas trīs:

- indivīdi,

- uzñēmēji,

- valsts.

Trešajā līmenī tiks definēti vērtēšanas kritēriji (kritēriju grupu intereses). Komponenti kritēriju grupām tika noteikti fokusgrupas 


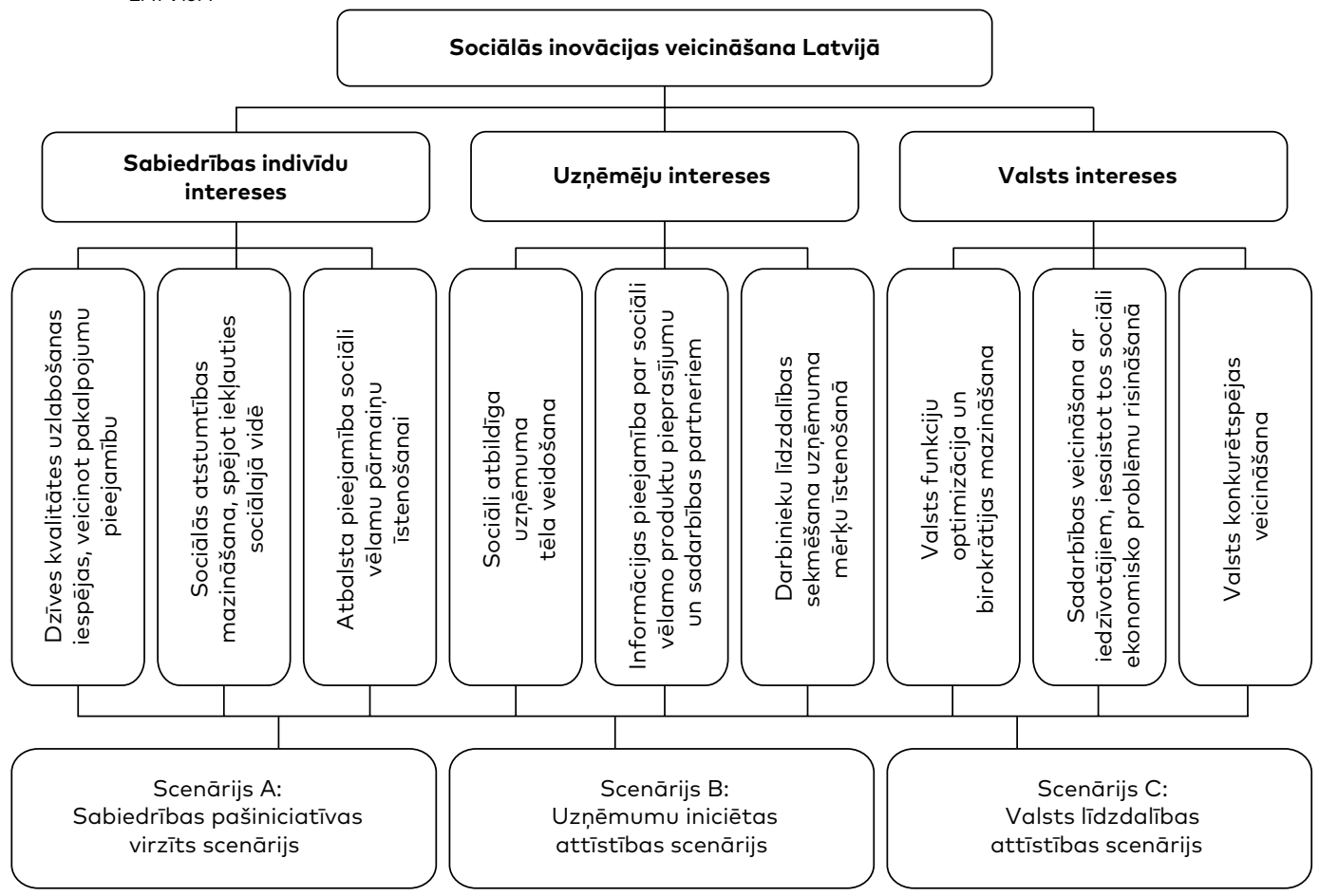

Avots: Dobele, Grīnberga-Zālīte \& Kelle, 2015: 154.

12. attēls. Vērtēšanas kritēriju hierarhija sociālās inovācijas veicināšanai Latvijā.

diskusijas rezultātā, pamatojoties uz ekspertu vērtējumu un teorētisko pētījumu par sociālo inovāciju attīstību raksturojošām komponentēm.

Ceturtajā līmenī tika analizēti trīs sociālās inovācijas attīstības scenāriju varianti (alternatīvas):

1) sabiedrības pašiniciatīvas virzīts scenārijs - sociālā inovācija kā brīvprātīgo darbs;

2) valsts iniciatīvas virzīts scenārijs - sociālā inovācija kā valsts ilgtspējīgas attīstības veicināšanas nosacījums;

3) uzñēmumu iniciatīvas virzīts scenārijs - sociālā inovācija kā korporatīvās sociālās atbildības būtiska sastāvdalı.

Izvirzītie scenāriji (alternatīvas) ekspertiem bija jānovērtē attiecībā pret otrās un trešās grupas kritērijiem. Scenāriju veidošanai un novērtēšanai tika izmantota diferencētā pieeja, proti, scenārijus veidoja pētījuma autores, bet scenāriju novērtēšanu veica pieci eksperti, kuri pārstāvēja dažādas interešu grupas: 
1) uzṇēmējs, SIA “Oskars un partneri” dibinātājs. Uzṇēmums strādā kopš 2006. gada, pamatdarbība - datortehnikas apkalpošana un tirdzniecība. Uzñēmējs ir sociāli inovatīvā projekta "Laika banka" dalībnieks un plāno nākotnē īstenot līdzīgu projektu;

2) uzṇēmēja, SIA “Gaḷas pārstrādes uzṇēmums "Nākotne"” valdes locekle. Uzṇēmums dibināts 2000. gadā, nodarbina 300 darbinieku un praksē ievieš sociāli inovatīvus risinājumus uzṇēmuma lìmenī;

3) valsts amatpersona, Latvijas Republikas Ekonomikas ministrijas valsts sekretārs;

4) valsts amatpersona, a/s "Valsts nekustamie īpašumi" vadošais namu pārvaldnieks;

5) NVO pārstāve, "Lauku partnerības “Lielupe"” valdes priekšsēdētāja.

Ekspertu skaita izvēli noteica divi kritēriji:

1) ekspertu skaita ierobežotības nepieciešamība. Ekspertu skaitam nav jābūt lielam, jo pretējā gadījumā var samazināties ekspertu grupas vidējā kompetence. Taču mazās grupās atsevišksu ekspertu subjektīvais vērtējums var būtiski ietekmēt vērtējumu saskan,otību;

2) ekspertu zināšanas un kompetence sociālajā inovācijā.

Sākotnēji ekspertiem bija jāsalīdzina otrajā līmenī iekḷautās kritēriju grupas pa pāriem attiecībā pret kopējo mērḳi pirmajā līmenī. Kritēriju salīdzināšanai izmantota standartizēta relatīvā svarīguma skala. Kritēriju grupu salīdzināšanas rezultātus katrs eksperts ierakstīja tabulā, kas tika jau iepriekš izveidota.

Apkopojot visus iegūtos ekspertu vērtējumus, var secināt, ka, attīstot sociālās inovācijas, visnozīmīgākās ir valsts intereses jeb valsts ieguvums $(0,38)$. Šai kritēriju grupai ir arī vismazākais variācijas koeficients, t. i., 14,6 \%, kas liecina par lielāko ekspertu vienprātību šajā jautājumā (sk. 13. attēlu).

Šāds rezultāts izriet no fakta, ka valsts ir tā, kas gūst lielāko labumu no sociālās inovācijas veicināšanas un attīstības. Tas izpaudīsies valsts konkurētspējas pieaugumā un sociāli ekonomisko problēmu risināšanā, iesaistot šajā procesā iedzīvotājus. Attiecīgi tālāk šo labumu izjutīs arī uzṇēmēji un sabiedrības indivīdi. Tas izskaidro ekspertu vērtējumu šajā kritēriju grupā, proti, mazāk nozīmīgākais labums no sociālo inovāciju attīstības ir sabiedrības indivīdiem (prioritāšu vektora koordinātes aritmētiskais vidējais vērtējums - 0,30), taču šai kritēriju grupai ir vislielākais variācijas koeficients, t. i., 48,7 \%, kas liecina par ekspertu viedokḷu kraso atšksirību šajā jautājumā. Tas skaidrojams ar to, ka sabiedrības indivīdi izjutīs sociālās inovācijas pozitīvo ietekmi dzīves kvalitātes uzlabošanās un sociālās atstumtības mazināšanās ziṇā, taču tajā pašā laikā šì ietekme var būt neliela un maz jūtama. 


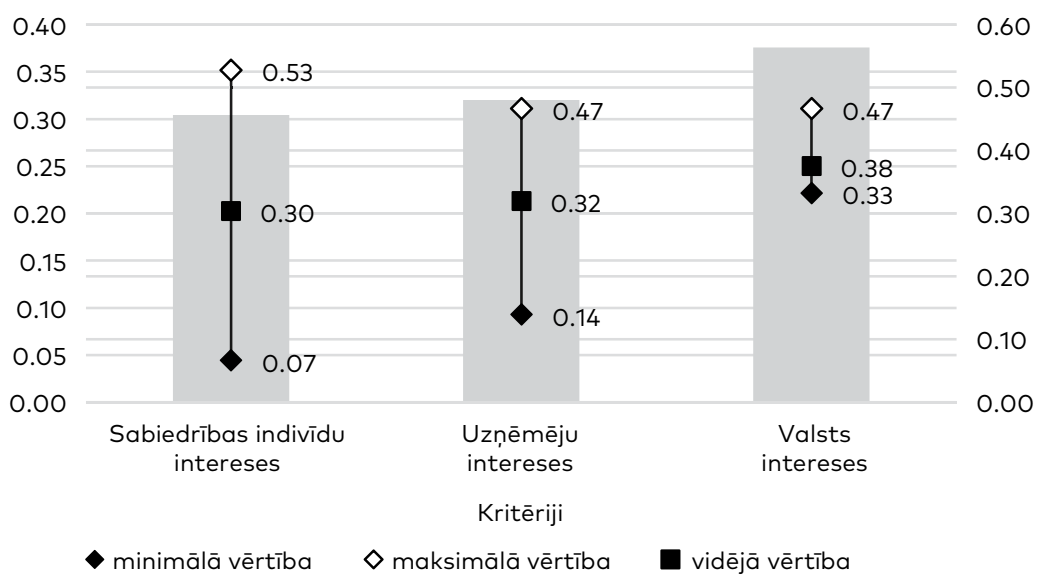

Avots: Dobele, Grīnberga-Zālīte \& Kelle, 2015: 155.

13. attēls. Ekspertu vērtējums pa kritēriju grupām.

Hierarhijas analīzes metodes rezultātā tika noteikta alternatīvu loma galvenā mērksa sasniegšanā pēc visiem deviņiem kritērijiem. Eksperti par optimālāko scenāriju noteica valsts iniciatīvas virzītu scenāriju (globālās prioritātes vektors - 0,45), kam seko uzṇēmumu iniciatīvas virzīts scenārijs $(0,35)$ (sk. 14. attēlu).

Valsts iniciatīvas virzìts scenārijs ir dominējošais arī prioritātes aprēḳinos pa atsevišķām kritēriju grupām, izṇemot no uzṇēmēju interešu pozīcijām, kad par optimālāko scenāriju ekspertu vērtējumā tika atzìts uzñēmumu iniciatīvas virzìtais scenārijs.

No veiktā pētījuma var secināt, ka saskaṇā ar ekspertu vērtējumu vissvarīgāk ir ieviest valsts atbalsta instrumentus sociālās inovācijas veicināšanai, tajā skaitā arī radīt atbilstošu normatīvo bāzi un izstrādāt finanšu un informatīvos atbalsta instrumentus sociālās inovācijas virzìtājiem un īstenotājiem. To apliecina valsts iniciatīvas virzītā scenārija noteikšana par prioritāro. Turklāt tam bija zema izkliede ap vidējo radītāju (14\%), ko var izskaidrot ar faktu, ka visi eksperti apzinājās, ka ir būtiski nodrošināt normatīvo bāzi sociālajām inovācijām un ieviest atbalsta instrumentus to attīstībai, lai risinātu sociāli ekonomiskās problēmas valstī.

Augstais uzṇēmumu iniciatīvas virzītā scenārija novērtējums (globālās prioritātes vektors - 0,35) liecina, ka arī uzñēmumiem ir svarīga loma sociālās inovācijas virzīšanā.

Visbeidzot, ekspertu vērtējuma rezultāti norāda, ka bez indivīda paša aktivitātes un iniciatīvas nav iespējama sekmīga sociālo inovāciju virzīšana. Arī šì scenārija vērtējumā ir augsta ekspertu vienprātība (23 \% 


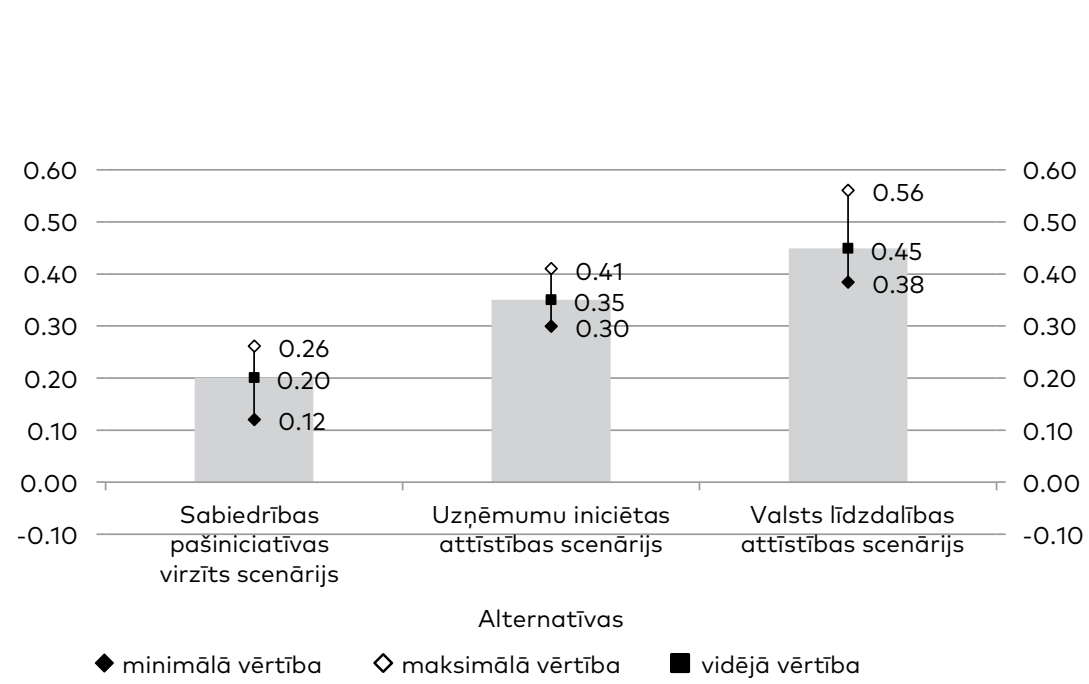

Avots: Dobele, Grīnberga-Zālīte \& Kelle, 2015: 156.

14. attēls. Sociālās inovācijas attīstības alternatīvie globālie prioritāšu vektori.

izkliede ap vidējo radītāju). Tas nozīmē, ka pamatā visi eksperti uzskata, ka sociālo inovāciju attīstība nav iespējama bez dažādiem atbalsta instrumentiem, bet tajā pašā laikā svarīga ir arī indivīda pašiniciatīva.

Rezumējot visus iepriekš iegūtos rezultātus katrā no pētījuma darba posmiem un kompleksi izvērtējot trīs scenārijus pēc hierarhijas analīzes metodes, tika konstatēts, ka piemērotākais scenārijs sociālās inovācijas attīstībai Latvijā ir valsts iniciatīvas virzīts scenārijs. Šāda scenārija aktualitāti šobrīd nosaka nepieciešamība radīt atbilstošu normatīvo bāzi sociālās inovācijas veicināšanai un izstrādāt finanšu un informatīvos atbalsta instrumentus sociālās inovācijas virzìtājiem un īstenotājiem.

\section{Secinājumi}

1. Sociālās inovācijas virzīšanā iniciatīvu var uzṇemties sabiedrība (balstoties savā pašiniciatīvā), valsts, kā arī uzṇēmēji, izmantojot atbilstošus atbalsta instrumentus. Tāpēc arī tika izstrādāti trīs sociālās inovācijas veicināšanas scenāriji Latvijas ekonomikas attīstības sekmēšanai: sabiedrības pašiniciatīvas virzīts scenārijs - sociālā inovācija kā brīvprātīgo darbs; valsts iniciatīvas virzīts scenārijs - sociālā inovācija kā valsts ilgtspējīgas attīstības veicināšanas nosacījums; uzṇēmumu iniciatīvas virzīts scenārijs sociālā inovācija kā korporatīvās sociālās atbildības būtiska sastāvdaḷa. 
2. Par optimālāko scenāriju tika noteikts valsts iniciatīvas virzītais scenārijs. Tas nozīmē, ka šobrīd Latvijā vissvarīgāk ir ieviest valsts atbalsta instrumentus sociālās inovācijas veicināšanai, tajā skaitā arī radīt atbilstošu normatīvo bāzi un izstrādāt finanšu un informatīvos atbalsta instrumentus sociālās inovācijas virzītājiem un īstenotājiem.

3. Lai arī abi pārējie scenāriji tika novērtēti kā mazāk piemēroti, tomēr pētījuma rezultāti liecina, kā arī uzṇēmumiem ir svarīga loma sociālās inovācijas virzīšanā. Turklāt bez indivīda paša aktivitātes un iniciatīvas nav iespējama sociālās inovācijas sekmīga virzīšana. 


\section{SOCIĀLĀS INOVĀCIJAS PIEREDZE LATVIJĀ: SOCIĀLĀS PROBLĒMAS UN TO RISINĀJUMI}

\section{GUNTA GRĪNBERGA-ZĀLĪTE, LĀSMA LĪCĪTE, LAURA JEROŠČENKOVA}

Latvijas iedzīvotājos pamazām veidojas izpratne par sociālās inovācijas projektu būtību, un ir publiski pieejama arī vairāku šādu projektu īstenošanas pieredze - ir īstenoti gan pavisam vienkārši projekti atsevišķas kopienas ${ }^{3}$ dzīves telpas labiekārtošanai kādā konkrētā Latvijas teritorijā, gan arī sarežgî̀ti projekti, kuru dalībnieku tīkls iekḷauj visu Latvijas teritoriju un sadarbības partnerus no ārvalstīm. Lai kāds arī būtu sociālās inovācijas projekta apjoms, būtiskākais ir tas, ka sociālās inovācijas primārais mērḳis ir kādas sabiedrībai aktuālas vajadzības apmierināšana. Ne tikai Latvijas, bet arī pasaules pieredze liecina, ka parasti materiāli nodrošinātas un pašpietiekamas kopienas ir mazāk ieinteresētas sociālās inovācijas attīstībā. Tomēr pašreizējos apstākḷos, kad globālā līmenī ne tikai vājas, bet arī stipras tautsaimniecības sistēmas vairs nespēj pārvarēt aizvien pieaugošo sociālo problēmu spriedzi, arī Latvijā pieaug nepieciešamība pēc inovatīviem risinājumiem tādām globālām problēmām kā sabiedrības novecošanās, nevienmērīga reǵionu attīstība, ko rada augstais urbanizācijas līmenis, sabiedrības integrācija, veselības aprūpe $u$. c.

Lai arī šobrīd Latvijā pastāv galvenokārt tās pašas sociālās problēmas, kādas ir citās attīstītās pasaules valstīs, tomēr viens no visbūtiskākajiem dienas kārtības jautājumiem jau kopš Latvijas neatkarības atgūšanas vēl joprojām ir nevienmērīga valsts reǵionālā

\footnotetext{
3 Sociālās inovācijas projektos ar apzīmējumu "kopiena" tiek raksturota cilvēku grupu, kurai ir kopīgas teritoriālās, ekonomiskās, sociālās un/vai kultūras intereses.
} 
attīstība. Latvijas sabiedrībā ierasts laukus pretstatīt pilsētai, no kā izriet, ka pilsētas parasti tiek saistītas ar attīstību, turpretī lauki ir un paliek kā problēmzonas. Lauku kā savdabīgas sociāli ekonomiskas kultūrvides atzīšana nozīmē, ka lauku problēmu risināšanai un attīstības veicināšanai būtu nepieciešams rast tādus inovatīvus risinājumus, kuros tiktu n,emtas vērā lauku īpatnības, t. i., izkliedēts cilvēkkapitāls, mazāk attīstīta infrastruktūra, ciešas kopienu saiknes u. c. (Šūmane, 2010). Sociālās inovācijas attīstības nepieciešamību laukos nosaka arī vairākas valsts līmenī neatrisinātas problēmas: nespēja nodrošināt kvalitatīvus izglītības pakalpojumus, kā rezultātā ǵimenes ar bērniem pamet laukus, lai dotos uz pilsētām; bezdarbs, kas rada sabiedrības noslānošanos un degradāciju; veca gada gājuma cilvēku un cilvēku ar īpašām vajadzībām pamestība, jo trūkst socializācijas iespēju. Ir būtiski atzīmēt, ka, neskatoties uz šìm problēmām, Latvijā laukos vēl joprojām dzīvo gandrīz trešdaḷa Latvijas iedzīvotāju un lauksaimniecība un ar to saistītie pakalpojumi veido vairāk nekā $3 \%$ no IKP (CSP, 2017, 2018). Turklāt lauksaimniecības sektors ir viens no tiem tautsaimniecības sektoriem, kuri ir ne tikai cieši saistīti ar valsts attīstību, bet arī ar visas Eiropas Savienības kopējo attīstību. Tādējādi arī turpmākajos gados visu ES dalībvalstu nacionāla līmeṇa mērḳi ir mērkstiecīga un efektīva lauksaimniecības, mežsaimniecības, kā arī lauku tūrisma un citu lauku teritoriju zemes izmantošana, nodrošinot zemes apsaimniekošanu ar maksimālu vērtības pievienošanu, tādējādi uzlabojot vietējo iedzīvotāju ienākumu gūšanu, dzīves kvalitātes uzlabošanos un ilgtspējīgu resursu izmantošanu. Latvijas lauku attīstības programmas 2014.-2020. gadam stratēǵija ir cieši saistīta ar Latvijas Nacionālo attīstības plānu 2014.-2020. gadam, kurš ir augstākā līmeṇa plānošanas dokuments un atbilst Eiropas Savienības stratēgiskās plānošanas dokumentiem. Lai sasniegtu šos mērḳus, nepieciešama pārdomāta lauku attīstības politika, kas veicinātu lauku iedzīvotāju spēju pašorganizēties un pielāgoties pašreizējiem lauku vides apstākḷiem.

Kudiṇš uzsver, ka sociāli vēlama rezultāta sasniegšanā būtiska nozīme ir:

1) spējai pašorganizēties grupās,

2) spējai mobilizēt vietējos resursus,

3) spējai piesaistīt citus resursus (Kudiṇš, 2012).

Latvijas iedzīvotāju blīvuma un ekonomiskās aktivitātes salīdzinājums novados liecina, ka noteiktā teritorijā dzīvojošo iedzīvotāju skaits ne vienmēr ir izškirīgais kritērijs kādas teritorijas attīstībai, jo cēlonis šìm atšķirībām bieži vien sakṇojas citos ietekmes faktoros - pirmkārt jau konkrētās teritorijas cilvēkkapitālā un tā raksturlielumos (intelekts, zināšanas, organizatoriskās spējas, veselības stāvoklis, vecums, dzimums), kā arī teritorijas pārvaldības kompetencē un kapacitātē, jo 
vienus un tos pašus fiziskos, finansiālos un cilvēku resursus var organiSociālās inovācijas zēt dažādi (Jeroščenkova, 2016).

Katra sociālā inovācija balstās uz labu ideju, bet ne visas labās idejas pieredze Latvijā: sociālās problēmas un to risinājumi tiek îstenotas, jo nesaṇem kopienas atbalstu. Bieži sabiedrības pasivitātes iemesls sakṇojas sociālās sistēmas stabilitātes problemātikā, jo inovācija vienmēr ir saistīta ar izmaiṇām un nepieciešamību pēc jauniem sadarbības veidiem, bet cilvēkus viṇu ierastajā kārtībā vairāk satrauc inovācijas radītās potenciālās izmaiṇas nekā inovācijas radītie ieguvumi. Latvijas kontekstā to varētu skaidrot ar latviešu viensētnieka mentalitāti un vecāka gadagājuma cilvēku negatīvo pieredzi padomju kolhozos un pēc Latvijas neatkarības atjaunošanas 90. gadu kooperatīvos, kuri l’oti bieži izkroploja kooperācijas ideju un labās tradīcijas. Tādēl arī cilvēki bieži izturas piesardzīgi pret jauniem, netradicionāliem sadarbības veidiem un partneriem.

\section{Ārējo un iekšējo faktoru virzīta sociālo inovāciju attīstība}

Sociālo inovāciju ideju attīstība var būt gan eksogēna (tāda, kas rod izpausmi ārēju faktoru ietekmē), gan endogēna (tāda, kas rod izpausmi iekšēju faktoru ietekmē).

\section{Ārēju faktoru virzīti sociālās inovācijas projekti Latvijā}

“Tiešā pirkšana” (sabiedrības pašiniciatīvas virzīts projekts; uzñēmumu un iedzīvotāju sadarbība; veicina vietējo lauku iedzīvotāju ienākumu gūšanu, dzīves kvalitātes uzlabošanos un ilgtspējīgu resursu izmantošanu)

Kā pozitīvu piemēru eksogēnai sociālās inovācijas attīstībai var minēt tiešās pirkšanas kustību. Kustības pirmsākumos aktīvi sociālie aǵenti no pilsētām saskatīja potenciālu lauku uzṇēmēju un pilsētnieku sadarbībai, dibinot tiešās pirkšanas pulciṇus, kas savā ziṇā ir sociālā inovācija un kas jau vairākus gadu desmitus darbojas citās pasaules valstīs. Lai arī Latvijā šì kustība ir kḷuvusi populāra vien nesen, tajā pakāpeniski iesaistās aizvien vairāk pircēju un pārdevēju. Šādas sociālās inovācijas cēlonis ir apstāklis, ka visā pasaulē cilvēki arvien vairāk cenšas izzināt, kur tiek saražoti pārtikas produkti un cik tie ir veselīgi. Arī Latvijā nu jau ir izveidojusies organizēta kustība, iesaistot tos pircējus, kam šie jautājumi ir aktuāli un kas ir gatavi iegādāties pārtiku nevis veikalos, bet tieši no lauku saimniecībām.

Kustība "Tiešā pirkšana" aizsākās pirms pieciem gadiem, kad tās iniciatore Zane Ruǵēna nolēma krasi mainīt savus pirkšanas paradumus. 
Viṇa izlēma, ka turpmāk savai ǵimenei iegādāsies ekoloǵisku pārtiku. Šim nolūkam Z. Ruǵēna apzināja sev tuvumā dzīvojošos zemniekus un sāka iegādāties no tiem pārtiku bez starpnieku uzcenojuma, gūstot skaidru izpratni un pārliecību par katra produkta ražošanas ciklu un to, kā tas tiek aprūpēts. Ar laiku interese par šiem produktiem arī no citu viṇas paziṇu un draugu puses auga, kā rezultātā Z. Ruǵēna apzinājās, ka pati nespēs izbraukāt pakal aizvien pieaugošajam produktu apjomam. Izzinot, kā šāda kustība darbojas Francijā, Zane Ruǵēna un Elīna Zuša izveidoja pirmo tiešās pirkšanas pulciṇu arī Latvijā, Rīgā.

Tiešās pirkšanas pulciṇi darbojas saskaṇā ar rūpīgi izstrādātu sistēmu, kuras pamatā ir dalībnieku brīvprātīgais darbs. Katrā pulciṇā ir iesaistītas 15 līdz 40 ǵimenes, un tās sadarbojas ar sev tuvumā esošajām zemnieku saimniecībām, kurām ir pieškirts biologiskās lauksaimniecības statuss un kuras ir gatavas sadarboties, tādējādi nodrošinot tiešās pirkšanas pulciṇus ar pašaudzētiem dārzen,iem, svaigiem augliem, galu, zivīm, olām, medu, saldumiem, tējām, graudaugiem un citiem uz vietas audzētiem produktiem. Svarīgs aspekts ir arī nodrošināt atbilstošas telpas, kur produkti tiek saṇemti no zemniekiem un uzglabāti pirms nodošanas tālāk ǵimenēm. Z. Ruǵēna un E. Zuša ir izstrādājušas viegli saprotamu un replicējamu sistēmu, kuru var ieviest katrā pulciṇā. Sistēmai pamatā ir brīvprātības princips: kurš biedrs var, tas attiecīgajā nedēlā pats piesakās par dežurantu. Nedēḷas dežurants attiecīgajā nedēl’as dienā apzvana zemniekus un noskaidro, kādi produkti tajā brīdi ir piedāvājumā un kādos apjomos tos iespējams pasūtīt. Saṇemtā informācija tiek apkopota un nodota pārējiem pulciṇa dalībniekiem, kuri pāris turpmākajās dienās var veikt pasūtījumus. Kad dalībnieku pasūtījumi ir apzināti, dežurants tos nodod zemniekiem, kuri pa nedēḷas nogali sagatavo attiecīgos produktus un atved uz pulciṇa telpām (Jēgere, 2015). Tiešās pirkšanas pulciṇu iniciatīva Latvijā strauji aug un attīstās, un iesaistīto mājsaimniecību skaits jau tuvojas diviem tūkstošiem. Sociāli inovatīvās idejas autores arī aktīvi dalās ar savu pieredzi un rīko seminārus jauniem interesentiem Rīgā un citās pilsētās, tādējādi motivējot cilvēkus iesaistīties un veidot pašiem savus pulciṇus, kā arī konsultējot tos, kuri savus pulciņus jau ir izveidojuši.

Protams, šāda sociālā inovācija joprojām ir pilnveidojama, piemēram, cenas ziṇā lauku mājražotāju produkti bieži nespēj konkurēt ar lielveikala konvencionālās lauksaimniecības produktiem, un pircēju izpratne un zināšanas par lauksaimniecības preču tirgu un cenas faktoriem ir nepietiekamas. Arī produktu pasūtīšana tiešās pirkšanas pulciņos vēl joprojām sagādā pircējiem vairākas neērtības - produktu pasūtījums jāplāno un jāpasūta krietni iepriekš, un to pēc pasūtīšanas ir sarežgîti korigêet. Visbeidzot, tiešās pirkšanas pulciṇu brīvprātīgais darbs ir neatṇemama šāda modeḷa sastāvdaḷa, un mūsdienās jaunām giimenēm 
ar bērniem tiešām ir maz brīvā laika, ko veltīt šādām regulārām aktivitātēm. Turklāt nelielās lauku saimniecībās zemnieki ir daudz vairāk pakḷauti dabas stihiju un lauksaimniecības dzīvnieku slimību ietekmes sekām nekā lielās komerciālās saimniecībās, kā rezultātā patērētāja drošība un uzticība šãdam piegādātājam nav tik liela kā lielveikalu ksēdēm.

"Humusa komanda" (sociālā uznēemuma pašiniciatīvas virzìts projekts; uzñēmumu sadarbība savā starpā; veicina sociāli mazaizsargāto kopienu integrāciju sabiedrībā un darba tirgū)

Akūta sociālā problēma, kas pastāv gan laukos, gan pilsētās, ir sociāli mazaizsargāto kopienu integrēšana darba tirgū. Tas attiecas gan uz vietējām romu kopienām, gan arī nu jau skaita ziṇā pieaugošajām ekonomisko un politisko bēgḷ kopienām. Kā inovatīvu eksogēnas sociālās inovācijas attīstības piemēru šīs problēmas risināšanai var atzīmēt arī uzñēmumu "Humusa komanda", kas izveidots ar nolūku radīt darbavietas cilvēkiem no Tuvo Austrumu valstīm, kuri ieguvuši bēgḷa vai alternatīvo statusu Latvijā (Jauns.lv, 2017).

Uzṇēmums ir neliels ēdienu ražotājuzṇēmums, kas piedāvā autentiskus un gardus Tuvo Austrumu ēdienus un èdienu gatavošanā un pārdošanā iesaista cilvēkus no Tuvo Austrumu valstīm, lai tādējādi mazinātu negatīvos stereotipus par bēgliem no Tuvajiem Austrumiem, kā arī lai uzlabotu vinu dzīves apstākḷus un sekmētu kultūras mijiedarbību, un nodrošinātu draudzīgu saskarsmi starp bēgḷiem un vietējiem Latvijas iedzīvotājiem. Daudzi Latvijas komercuzṇēmumi mērḳtiecīgi sadarbojas ar "Humusa komandu", pasūtot saviem biroja darbiniekiem pusdienas no šì sociālā uzṇēmuma, tādējādi paužot savu atbalstu bēg̣̣u dzīves apstākḷu uzlabošanai un bēgḷu integrācijai Latvijas sabiedrībā.

\section{lekšēju faktoru virzīti sociālās inovācijas projekti Latvijā}

Raksturojot sociālās inovācijas endogēnu attīstību, jāatzīst, ka "Eurostat" apkopotie statistikas dati par inovatīvi aktīvo uznēemumu īpatsvaru ES valstu tautsaimniecībā 2012.-2014. gadā atspoguḷo Latvijai šobrīd neglaimojošu situāciju, proti, to uzṇēmumu īpatsvars Latvijā, kuri šajā periodā tirgū bija ieviesuši inovāciju, bija tikai 6,3 \% (vēl zemāks rādītājs novērojams tikai Rumānijā), kas salīdzinoši ar attīstītākajām ES dalībvalstīm Vāciju $(58,3 \%)$ un Austriju $(47,8 \%)$ ir loti zems. Tehnoloğiskas inovācijas ieviešana uzṇēmumā nozīmē, ka tiek veiktas ar produktu un/vai ražošanas procesu saistītas inovatīvas darbības. Turpretī ar ne-tehnologisku inovāciju saprot inovatīvas darbības organizatoriskajā un tirgus jomā (Pilvere u. c., 2014). Jāpiebilst, ka ne-tehnoloğiskas inovācijas saistība ar sociālo inovāciju ir ḷoti cieša, jo attīstītās tautsaimniecībās ne-tehnologiskā inovācija atspoguḷo ne tikai tiešu uzṇēmumu
Sociālās inovācijas pieredze Latvijā: sociālās problēmas un to risinājumi 
konkurētspējas veicināšanas un rentabilitātes paaugstināšanas motivāciju, bet arī vēlmi uzlabot darbinieku veselību un darba drošību, mazināt uzṇēmumu darbības ietekmi uz vidi, novecojušu un neefektīvu produktu aizstāšanu ar jauniem, kas sniedz labumu sabiedrībai kopumā un ir neatn,emama korporatīvās sociālās atbildības sastāvdaḷa.

“HOPP” (sociālā uzṇēmuma pašiniciatìvas virzìts projekts; uzṇēmuma un iedzīvotāju sadarbība; mazina invalīdu un senioru sociālo izolētību)

Viens no uzṇēmumiem Latvijā, kas īsteno tehnoloǵiskas inovācijas projektus un ko raksturo endogēna sociālās inovācijas attīstība, ir sociālais uzñēmums "HOPP”. Uzñēmums ir dibināts 2010. gadā un ražo trīsritenus cilvēkiem ar kustību traucējumiem un senioriem. Ražotais trīsritenis pilda ne tikai tehniskās funkcijas kā palīglīdzeklis fiziskajām aktivitātēm, bet ir arī veids, kā mazināt atsevišku cilvēku izolētību. Kā skaidro uzṇēmuma vadītāja Madara Makare, daudziem cilvēkiem šāds ritenis nodrošina iespēju iziet ārā no mājām, būt ar draugiem, un dažviet laukos tā ir vienīgā iespēja senioriem tikt līdz veikalam.

Uzṇēmums radās, n,emot vērā klientu pieprasījumu. Reiz kāds klients, kuram bija kājas protēze un grūtības pārvietoties, personīgi vērsās pie uzṇēmuma pārstāvjiem ar lūgumu izgatavot tam trīsriteni, un tas arī tika veiksmīgi uzkonstruēts garāžas tipa ražotnē. Tā radās pamats uzsākt sociālo uznēēējdarbību un nodibināt sociālo uznēēmumu "HOPP". Uznēēmums, izmantojot uzṇēmējdarbības instrumentus, pievērsās sociālo problēmu risināšanai. Uzṇēmums sniedz iespēju cilvēkiem ar invaliditāti dzīvot pilnvērtīgāku dzīvi.

Viens no būtiskākajiem faktoriem, kas ietekmē uzṇēmuma attīstību, ir finanšu atbalsta trūkums no valsts, kas ir nepieciešams, jo mērksauditorijai ir zema maksātspēja, turklāt uznēmuma darbību ietekmē proporcionāli lielais nodokḷu slogs, kas kavē galvenās misijas īstenošanu. Eiropā šādus trīsritenus ražo rūpnieciski, un to atbalsta valdības un pašvaldības. Arī Latvijā cilvēkiem tie ir nepieciešami, bet finansiālu apsvērumu dēl viṇi nevar atḷauties tos iegādāties Eiropā. "HOPP" savu produkciju netirgo par tirgus cenu, bet par cenu, kas ir tuva pašizmaksai (speciālo riten,u pašizmaksa ir ap 520 eiro), turklāt uzṇēmēji paši meklē atbalstītājus, kuri var palīdzēt šiem riteņiem nonākt pie lietotājiem. Uzṇēmumam ir arī pieredze ar veiksmīgiem labdarības projektiem (Makare, 2012). Tāpat sociālais uzṇēmums aktīvi piedalās dažādos ar sociālo uzñēmējdarbību saistītos semināros un tādos pasākumos kā "Veselīga dzīvesveida diena Mežaparkā", "Paraolimpiskā sporta diena Rīgā". Sadarbībā ar biedrību "Latvijas bērniem ar kustību traucējumiem” uzṇēmums organizē ikgadēju projektu, kura ietvaros uzñēmēji tiek aicināti atbalstīt 10 trīsritenuu izgatavošanu bērniem un jauniešiem ar kustību traucējumiem. Šì projekta laikā saražotie trīsriten,i bez atlīdzības tiek nodoti 
bērniem un jauniešiem, kuriem šis pārvietošanās līdzeklis ir akūti nepieciešams. Var secināt, ka, lai efektīvi īstenotu sociālo inovāciju, ir būtiski veidot sadarbību ar dažādām ieinteresētajām pusēm - uzñēmējiem, pašvaldību, nevalstiskajām organizācijām. Tas ir nozīmīgi ne tikai tāpēc, lai varētu uzsākt sociālās inovācijas ieviešanu dzīvē, bet arī lai sabiedrībā ilgtermiṇā varētu risināt sociālās problēmas.

“Žēlsirdības māja” (sabiedrības pašiniciatīvas virzìts projekts; NVO, pašvaldības un valsts sadarbība; mazina jauniešu invalīdu sociālo izolētību)

Raksturojot sociālās inovācijas endogēnu attīstību, jāatzīmē arī sociālais uzṇēmums "Žēlsirdības māja”, kas ir mājas alternatīva jauniešiem ar invaliditāti. Fonda darbība aizsākās 1992. gadā, kad tā dibinātāja Tatjana Bražṇika pati savās mājās uzṇēma trīs jauniešus, kuri tolaik klainnoja un bija bez pastāvīgas dzīvesvietas un ēdiena. Pamazām viṇas māja kḷuva par lielas ǵimenes māju, un izpausmi rada ideja par „Žēlsirdības mājas" izveidi. Vajadzība uzsākt uzṇēmējdarbību radās tādēl, ka fondam bija nepieciešami papildu finanšu līdzekḷi, kurus varēja iegūt, radot fonda jauniešiem reālas nodarbinātības iespējas.

Fonds "Žēlsirdības māja" ir racionāla alternatīva specializētajiem valsts sociālās aprūpes centriem (psihoneirologiskajiem internātiem), jo šeit jaunieši invalīdi ar garīga rakstura traucējumiem spēj dzīvot gimenes vidē, vienlaicīgi apgūstot arī turpmākajā dzīvē tik nepieciešamās sociālās un darba prasmes. "Žēlsirdības mājā" tiek pieṇemti jaunieši, kuri nāk no bērnunamiem un specializētajām internātskolām, kā arī sociālās aprūpes centriem. "Žēlsirdības māja" patvērumu devusi jau vismaz 100 jauniešiem. Lai tie saṇemtu kvalitatīvu aprūpi, fonda mājās vienlaicīgi tiek uzṇemti ne vairāk kā 16 jaunieši. Fonds apsaimnieko trīs īpašumus - mājas un zemi netālu no Ventspils -, kur jaunieši dzīvo, mācās pielāgoties patstāvīgai ikdienas dzīvei un apgūst darba prasmes.

"Žēlsirdības māja” sniedz mājas sajūtu cilvēkiem, kuri nekad nav dzīvojuši ǵimenē, - šī apstākḷa dēl tiem nav prasmju, kā rūpēties par sevi, savu dzīves telpu, un tie nesaprot, ko nozīmē sadarboties ar citiem. Nereti šie jaunieši pat nezina, kā pagatavot ēdienu. N,emot vērā sociālās problēmas, kādas pastāv invalīdiem Latvijā, T. Bražnika nolēma attīstīt uzṇēmējdarbību fonda paspārnē, jo viṇas iepriekšējā darbības pieredze liecināja: neskatoties uz to, ka vairāki "Žēlsirdības mājas" jaunieši bija apguvuši pavāra profesiju, tomēr pēc tam tie nespēja iekḷauties darba tirgū. Tas motivēja T. Bražņiku izveidot "slēgta tipa ēdināšanas uzñēmumu", kurā tika radītas darba vietas deviṇiem jauniešiem. Tādējādi jaunieši ne tikai papildināja zināšanas jau apgūtajā profesijā, bet arī ieguva darba stāžu, kas savukārt deva iespēju saṇemt invalīda pensiju, t. i., lielāku naudas summu nekā sociālais pabalsts bērnam invalīdam.
Sociālās inovācijas pieredze Latvijā: sociālās problēmas un to risinājumi 
Redzot, cik ḷoti jauniešiem patīk un labi padodas darbošanās virtuvē, T. Bražṇika izloloja ideju par kafejnīcas “Dižrausis” izveidi - tā kḷuva par nozīmīgu socializācijas punktu un arī sniedza iespēju pašiem pelnīt naudu, kas tiek novirzīta fonda darbības nodrošināšanai. Tādējādi fonds varēja turpināt iesākto darbu un sniegt mājas šai sabiedrības mazāk aizsargātajai grupai.

Kafejnīcas virtuvē profesionāla pavāra un konditora uzraudzībā strādā vidēji 10 jaunieši ar invaliditāti. Lai nodarbotos ar konditorejas izstrādājumu tirdzniecību arī ārpus izveidotās kafejnīcas telpām Kurzemes reǵionālajā slimnīcā, fonds ir saṇēmis mobilās tirdzniecības atlauju. Neskatoties uz paveikto, "Žēlsirdības māja" joprojām bieži saskaras ar finanšu problēmām, jo ienākumi no kafejnīcas nav lieli un arī invalīdu darba produktivitāte būtiski atpaliek no vesela jaunieša darbaspējām; tāpēc tiek meklētas arvien jaunas sadarbības iespējas ar dažādām mērksgrupām.

Līdz šim fonda darbību finansiāli atbalstījuši vairāki vietējie uzṇēmumi, kā arī privātpersonas, ziedojot gan naudu, gan drēbes, gan pārtiku. Arī kafejnīca tika izveidota ar atbalstītāju un ziedotāju palīdzību - tika izremontētas Ventspils domes piešksirtās telpas, iegādātas virtuves iekārtas, mēbeles un trauki. Lai gan telpas pieder pašvaldībai, kafejnīca no saviem ieñēmumiem apmaksā arī telpu nomas izdevumus.

Neapšaubāmi šādām ekonomiskām aktivitātēm ir vajadzīgs finansiāls atbalsts no valsts, it īpaši pirmajā darbības periodā. Raksturojot fonda darbību, jāsecina, ka fonds "Žēlsirdības māja" ar ekonomiskām aktivitātēm tiešā un netiešā veidā risina sociālu problēmu. Fonds ir organizācija, kuras mērḳis nav saistīts ar pel̦nas gūšanu, bet ir vērsts uz sociālo problēmu risināšanu, t. i., sociālo un darba prasmju iemācīšanu jauniešiem ar garīgās attīstības traucējumiem. Fonda ekonomiskās aktivitātes ir instruments vai veids, kā nodrošināt jauniešiem iespēju iegūt darba prasmes, kā arī radīt papildu līdzekḷus fonda darbības nodrošināšanai. Kafejnīcas izveide fonda paspārnē ir tikai viens no piemēriem, kā var veicināt invalīdu ar garīgas attīstības traucējumiem integrāciju sabiedrībā. Tomēr jāuzsver, ka bez īpaša valsts un pašvaldības atbalsta fonda veiktās uzñēmējdarbības aktivitātes ir pakḷautas dažādiem riskiem, piemēram, nespējai nomaksāt visus piekrītošos maksājumus. Šāda riska iestāšanās gadījumā kafejnīca var tikt slēgta. Slēdzot kafejnīcu, jaunieši zaudēs darbu, un pastāv tikai niecīga iespēja, ka tie jebkad spēs atrast citu algotu darbu (Sociālā uzṇēmējdarbība, 2013). 

veiksmīgas iekšējo faktoru virzītas sociālās inovācijas pieredzes pārṇemšanas projekti Latvijā

Lai arī finanšu pieejamības problēmas ir nopietns škēerslis sociālo inovāciju īstenošanai, tomēr visbūtiskākais iemesls, kāpēc Latvijas uzṇēmumi nespēj ieviest inovāciju, ir labu ideju trūkums. Šādas atziṇas norāda, ka tradicionālās sadarbības formas starp uzṇēmumiem, kuru pamatā ir tikai materiālā ieinteresētība sadarboties, sāk pamazām transformēties, un ir būtiski inovācijas attīstī̌sanā iesaistīt arī patērētājus, piegādātājus un sabiedrību kopumā, kas atbilst jaunā virziena "dalīšanās ekonomikas" (sharing economy) pamatnostādnēm. Dalīšanās ekonomiku var definēt kā "ekonomisku sistēmu, kurā indivīdi bez atlīdzības vai par samaksu dalās ar īpašumiem, prasmēm vai līdzekḷiem” (Botsman, 2015). Latvijas Bankas ekonomiste Māra Rūse uzsver, ka dalīšanās ekonomikas aktualitāti var izskaidrot ar trīs savstarpēji saistītiem cēloniem.

- Jaunas digitālās tehnologijas - interneta, mobilo tehnologiju un modernu maksājumu sistēmu attīstība veicina tādu uzñēmumu veidošanos, kuru biznesa modelis ir balstīts uz digitālajām platformām un mobilo ierīču lietotnēm.

- Sabiedrības pārmaiñas - dalīšanās ekonomiku veicina sociālās pārmaiṇas, kas izpaužas kā "dalī̌̌anās” kā plašāka sociāla parādība. Tā aizsākās ar informācijas apmaiṇu sociālajos tīklos un pakāpeniski izplatījās dažādās sadzīves jomās, piemēram, kopbraukšana, pūḷa finansējums u. c.

- Ekonomiskie apstākḷi - iedzīvotāji vēlas izmantot cenas ziṇā pieejamus un videi draudzīgus resursus. Globālās ekonomikas lejupslīde, kas pastiprināja sociālās nevienlīdzības problēmas sabiedrībā un veicināja bezdarba pieaugumu (it īpaši jauniešu vidū), deva impulsu cilvēkiem aktīvāk iesaistīties dalīšanās ekonomikas platformās, piedāvājot koplietot savu mājokli, mašīnu u. c. labumus, lai iegūtu papildu ienākumus vai saṇemtu citus nepieciešamos labumus no citiem koplietošanas organizāciju biedriem.

Pašlaik Latvijā jau darbojas tādi pasaulē atpazīstami "dalīšanās ekonomikas" idejas īstenotāji kā kopbraukšanas uzṇēmumi "Taxify" un "Autolevi", un drīzumā savu darbību cer uzsākt arī "Uber". Viesnīcu pakalpojumu jomā darbojas uzṇēmums "Airbnb”. Latvijā dibināto fintech (finanšu tehnoloǵiju) uzṇēmumu "Mintos" arī var pieskaitīt dalīšanās ekonomikai, jo tas paver plašākas un izmaksu ziṇā daudz pieejamākas iespējas aizṇemties finanšu līdzekḷus. Pie šādiem uzṇēmumiem pieskaitāmi arī "Piedarbs" (mājsaimniecības pakalpojumi), 
"Morethan" (mazlietotas mantas) un "Barking" (autostāvvietas) (Rūse, 2017).

“Tuvu” (sabiedrības pašiniciatīvas virzīts projekts; NVO sadarbība savā starpā; mazina sociālos riskus un sniedz dažāda veida atbalstu dažādām sabiedrības grupām)

Veiksmīgs piemērs "dalīšanās ekonomikas" attīstībai Latvijas reǵionos ir 2013. gadā nodibinātā biedrība "Tuvu", kuras mērḳis ir Latvijas gimeṇu, bērnu un vientuḷo cilvēku sociālās atstumtības un sociālā riska mazināšana un labklājības celšana. Šim nolūkam organizācija "Tuvu" sadarbojas ar līdzīgām labdarības organizācijām no Vācijas un Latvijas, kas ziedo apgēêrbu, apavus, sadzīves k,īmiju, mēbeles, sadzīves priekšmetus, pārtiku un citas preces. Biedrība "Tuvu" rīko arī dažādus pasākumus bērniem Zemgales reǵionā, nometnes pusaudžiem, kā arī veic būvniecības projektus, kuru laikā gimenēm ar bērniem tiek uzlabota dzīves vide. Neskatoties uz pašaizliedzīgo darbu sabiedrības labā, biedrības pārstāvji saskaras arī ar finanšu problēmām, jo nereti tikai ar palīdzības sniegšanu apgeērba, apavu vai mēbel̦u veidā nepietiek, tādēl nākas meklēt risinājumus, kā sniegt atbalstu tiem cilvēkiem, kuriem papildus vajadzīga arī specifiska palīdzība (medikamentu un pārtikas iegādei, veselības aprūpei, vai dzīves apstākḷu uzlabošanai), jo Latvijā daudzas gimenes joprojām dzīvo smagos apstākḷos. Vācu partneru mudināti un atbalstīti, biedrības pārstāvji nolēma iesaistīties sociālajā uzṇēmējdarbībā un atvērt labdarības veikalus Jelgavā un Tukumā. Visa peḷna tiek izmantota iepriekš minētajos labdarības projektos. Lai gan veikalos lielākoties tiek tirgotas vācu preces, arī Latvijas iedzīvotāji ir laipni aicināti ziedot sev vairs nevajadzīgās lietas, kas kādam citam vēl varētu būt noderīgas, izvēloties - vai šìm lietām nonākt veikalā un par iegūtajiem līdzekḷiem īstenot kādu projektu vai arī dot iespēju trūcīgajiem iedzìvotājiem tās saṇemt bez maksas. Veikalos ir iespējams iegādāties gan apgēerbu bērniem un pieaugušajiem, gan arī apavus, traukus, mēbeles un citas noderīgas lietas visai gimenei par draudzīgām cenām.

Labdarības veikalu "Tuvu" izveides rezultātā tiek risinātas gan vides, gan sociālās problēmas inovatīvā veidā, jo apgēerbam un citām veikalā pieejamajām lietām, tās pārdodot citiem cilvēkiem, tiek piešksirta "otrā dzīve". Turklāt iegūtie līdzekḷi tiek virzìti arī sabiedrībā aktuālu sociālo problēmu risināšanai - ǵimeṇu, bērnu un vientuḷo cilvēku sociālās atstumtības un sociālā riska mazināšanai un labklājības celšanai. Latvijā kopumā šāda sociālās uzṇēmējdarbības prakse ir salīdzinoši jauna, turklāt Jelgavā tas ir vienīgais labdarības veikals. Labdarības veikalos Jelgavā un Tukumā jaunieši bieži gūst pirmo darba pieredzi, izejot praksi uzṇēmumā. Sociālais uzñēmums ir labs piemērs arī veiksmīgas sadarbības veidošanai starp dažādām ieinteresētajām grupām. Organizācija "Tuvu” sadarbojas ar līdzīgās jomās strādājošām 
labdarības organizācijām no Vācijas un Latvijas, uzṇēmumiem, valsts Sociālās inovācijas iestādēm, izglītības iestādēm, kā arī brīvprātīgajiem, lai rastu iespēju sociāli neaizsargātiem cilvēkiem apmeklēt dažādus kultūras un sporta pieredze Latvijā: sociālās problēmas pasākumus un nodrošināt viṇiem cilvēka cienīgu dzīves līmeni.

“Otrā elpa” (sociāla uzṇēmuma pašiniciatīvas virzìts projekts; iedzīvotāju un uzṇēmuma sadarbība; veicina sociāli vēlamu attieksmi, iesaistoties vides saudzēšanas, labdarības un sociālās atbildības programmās)

Lìdzìgs darbības princips kā "Tuvu" ir arī labdarības veikalam "Otrā elpa", kas uzskatāms par vienu no sociālās uzṇēmējdarbības pionieriem Latvijā. Uzṇēmums sev ir izvirzījis trīs pamatvērtības: labdarību, vides saudzēšanu un sociālo atbildību. "Otrās elpas" misija ir būt par sabiedrības izvēlētu starpnieku labdarības projektu īstenošanā, kā arī veicināt sociālo vērtību izpratni, pozitīvas sociālās izmaiṇas un vides saudzēšanu. Uzñēmums tika dibināts 2009. gadā, un tas efektīvā veidā piesaista nepieciešamos līdzekḷus labdarības un sociālo projektu atbalstam. Cilvēki tiek aicināti ziedot sadzīvei noderīgas lietas: apgēerbus, apavus, aksesuārus, grāmatas, žurnālus, $C D, D V D$, plates, kasetes, interjera priekšmetus, rotaḷlietas, spēles, sporta preces, inventāru, mēbeles, elektropreces. Saziedotās mantas tiek šķirotas, un tālāk daḷa no tām tiek nogādāta patversmēs, sociālās palīdzības centros, bērnunamos, mazturīgajiem un citiem, kam tās varētu būt noderīgas. Daḷa mantu tiek atstāta veikalā un pārdota tālāk.

Kopš 2011. gada uzṇēmums rīko regulāru "Otrās elpas” stipendiju konkursu, tādējādi atbalstot dažādas sociālās iniciatīvas visā Latvijā. Reizi ceturksnī no saṇemtajiem pieteikumiem balsošanai tiek izvirzìti trīs projekti, kas atbilst vienai no trim uzñēmuma prioritātēm: sabiedriskais labums, sociālā uzṇēmējdarbība un vietējās kopienas iedzīvotāju dzīves kvalitātes uzlabošana, sociāli mazaizsargāto grupu labklājības celšana. 3000 eiro stipendijas ieguvēju nosaka veikalu klientu balsojums. Par katru vienā dienā veiktu pirkumu pircējs saṇem kuponu, kurš darbojas kā balsošanas žetons.

Pašlaik Latvijā ir trīs "Otrās elpas" veikali - divi Rīgā un viens Liepājā. "Otrā elpa" arī veido savu produkciju no saziedotajiem apgēerbiem, kuri ir labas kvalitātes, bet vairs nav aktuāli valkāšanai. Tērpu dizaineri pārveido lietotos apgērbus, radot jaunu produktu, piemēram, no džempera uztaisa siltās čībiṇas, no kleitas - priekšautu, no Andrito kafijas maisiem - somas utt. Var secināt, ka "Otrā elpa" inovatīvā veidā risina vides un sociālās problēmas, piešksirot "otru iespēju” lietām un sniedzot iespēju sociāli maznodrošinātiem indivīdiem iegūt lietas par mazāku samaksu vai pat par brīvu.

"BlindArt" (sabiedrības pašiniciatīvas virzīts projekts; uzṇēmumu, valsts un NVO sadarbība; dažāda veida atbalsta sniegšana neredzīgajiem un cilvēkiem ar īpašām vajadzībām) 
"Dalīšanās ekonomikas" piemērs ir arī sociālā biznesa projekts "BlindArt", kura mērķis ir sniegt atbalstu neredzīgajiem un cilvēkiem ar īpašām vajadzībām, iedvesmot viṇus lielākiem mērḳiem un veidot labvēlīgu vidi sociālā biznesa attīstībai. Projekts "BlindArt" tika uzsākts Latvijā 2007. gadā, kad notika pirmās radošās darbnīcas un izstādes neredzīgajiem cilvēkiem. Arī citur pasaulē ir radušās līdzīgas iniciatīvas, kurās neredzīgie un cilvēki ar īpašām vajadzībām rada vērtīgus mākslas darbus plašākai sabiedrībai, taču Latvijā šādu iniciatīvu ir maz. Viens no pirmajiem inovatīvajiem "BlindArt" projektiem bija izstādes “Ar rokām aiztikt!” organizēšana. Sākotnēji projekta ietvaros norisinājās trīs dienu radošās darbnīcas, kurās neredzīgie bērni veidoja lielformāta foto kolāžas, kas tika izstādītas Rīgā, Jelgavā un Liepājā. Izstādes “Ar rokām aiztikt!” ietvaros tika saziedoti 15000 eiro, kas tika novirzīti lasāmo aparātu iegādei neredzīgajiem un vājredzīgajiem Strazdumuižas vidusskolas skolēniem. 2008. gadā izstāde "Ar rokām aiztikt!" tika apbalvota radošās izcilības festivālā "ADWARDS", kategorijā "Vides objekti". 2012. gadā trīs no izstādes "Ar rokām aiztikt!" bērnu veidotajām foto kolāžām iekḷuva īpašajā starptautiskās reklāmas festivāla "Cannes Lions" lielformāta foto grāmatā, izturot konkurenci 10000 iesūtīto darbu vidū. 2014. gadā "BlindArt" neredzīgo un vājredzīgo bērnu veidotos mākslas darbus pārveidoja Jaungada apsveikumos un ieguva Grand Prix radošā izaicinājuma konkursā "Clear Challenge" par Jaungada apsveikumiem pilsētvidē. Pēc konkursa apsveikumus varēja apskatīt uz lielformāta reklāmas stendiem Rīgas ielās.

"BlindArt" aizsāka sadarbību arī ar t/p "Alfa", un "Mūzikas ierakstu gada balva 2015" ietvaros Strazdumuižas internātvidusskolas vājredzīgie un neredzīgie bērni radīja unikālu taktīlās mākslas darbu izstādi "Redzi mūziku?". Bērni, radot mākslas darbus, iedvesmu smēlās Latvijas mūziḳu izpildītajās dziesmās, kuras pēdējo sešu gadu laikā par labākajām bija atzinuši t/p "Alfa" apmeklētāji projekta "t/p "Alfa" Gada dziesma" balsojumā. Izstādes oriǵināldarbus bija iespējams iegādāties izsolē, kurā darbi tika pārdoti kopsummā par 505 eiro. Mūzikas gada balvas titula ieguvēji grupa "Musiqq" savu naudas balvu 1500 eiro apmērā dāvināja "BlindArt" projektam. Kopā tika iegūti 2005 eiro, kas tika novirzīti Strazdumuižas internātvidusskolas vizuālās mākslas darbnīcas labiekārtošanai.

Savukārt sadarbojoties ar "Latvijas Dzelzcel̦u", akcijas "Dzirdi, redzi, dzīvo" ietvaros "BlindArt" izstrādāja košu un bērniem saistošu informatīvo materiālu par drošību dzelzceḷa tuvumā. Tajā "Zeḳu zagla medības" grāmatu sērijas galvenais varonis Enterītis iepazīstina bērnus ar noteikumiem un cel̦a zīmēm, kuras jāiegaumē, lai droši pārvietotos vietās, kur notiek dzelzceḷa kustība. "Zeḳu zagḷa medības” ir līdz šim nebijusi 
bērnu pasaku grāmata četrās daḷās, kuras stāstu radījuši četri talantīgi Sociālās inovācijas neredzīgo biedrības dalībnieki. Desmit nedēl̦u garumā radošo darbnīcu ietvaros autori radīja tēlus un notikumus, kuri veido unikālu stāstu. pieredze Latvijā: sociālās problēmas Tādējādi ir radīta mūsdienīga bērnu literatūra, kas ir interesanta, izglītojoša un iedrošina lasītāju iepazīt pasauli. Grāmatas ilustrācijas īpašā taktīlās mākslas tehnikā ir radījuši Strazdumuižas internātvidusskolas neredzīgie un vājredzīgie skolēni. Bērni izmantoja iepriekš sagatavotus grāmatas tēlu trafaretus, kurus lika uz papīra un, vadoties pēc taustes, izdūra tiem apkārt koordinācijas punktus. Punkti iezīmē trafareta siluetu, kuru, taustot ar pirkstiem, bērni var izkrāsot. Taktīlās mākslas tehnikā radītās ilustrācijas pieškir stāstam papildu raksturu un dzīvību. "Zeḳu zag̣̣a medības" grāmatu sērija paredzēta gan redzīgiem, gan neredzīgiem bērniem pirmsskolas un sākumskolas vecumā, jo daḷu tirāžas plānots izdot Braila rakstā (BlindArt, 2017). Tādējādi jāsecina, ka "BlindArt" inovatīvā veidā risina problēmas, kas saistītas ar neredzīgo cilvēku pilnvērtīgāku iekḷaušanos sabiedrībā.

Izvērtējot sociālās inovācijas projektu specifiku Latvijā, jāpiekrīt Tida un Besanta (Tidd \& Bessant, 2010) atziṇām par sociālās inovācijas lomu mūsdienīgā tautsaimniecībā, ko viṇi salīdzina ar simbiozes efektu, kāds pastāv dabā starp bitēm un kokiem. Sociālās inovācijas kontekstā kā bites darbojas mazās vai nelielās Latvijas sabiedrības indivīdu kopienas, kuras pēc savas būtības ir mobilas, spēj ātri reaǵēt uz pārmaiñām vidē un, pats būtiskākais, tām ir labas idejas. Dabā bites ir tās, kas veic koku apputeksnēšanu. Savukārt koki sociālās inovācijas kontekstā ir lieli, mūsdienīgi uzṇēmumi un organizācijas, kuriem nereti trūkst kreativitātes un tiešas sasaistes ar produkta gala patērētāju, taču tie ir spēcīgi idejas attīstītāji, jo tiem ir pieejami gan materiālie, gan nemateriālie resursi, ietekme un sakari idejas attīstīšanai. Tādējādi abas sociālās inovācijas attīstības procesā iesaistītās puses papildina viena otras kapacitāti un kopīgiem spēkiem risina pastāvošās sociālās problēmas.

\section{Secinājumi}

1. Lielākā daḷa sociālās inovācijas projektu Latvijā ir sabiedrības pašiniciatīvas virzīti, un tie ir uzsākti, lai atrisinātu kādas nelielas sabiedrības grupas (visbiežāk sociāli mazaizsargātas grupas, tādas kā invalīdu, trūcīgo, senioru, bezdarbnieku, bēgḷ u. c.) vajadzības. Tādējādi sabiedrības pašiniciatīvas virzītais scenārijs šobrīd vairāk atbilst Latvijas sociālekonomiskajai situācijai. Tomēr, ņemot vērā, ka Latvijā ir sakārtojusies sociālās uzṇēmējdarbības tiesiskā bāze, nākotnē starp sociālajiem iniciatoriem varētu būt vairāk sabiedrību ar ierobežotu atbildību, ko šobrīd aktīvi registrē sociālie uzṇēmēji. 
Arī valsts iniciatīvas virzīts scenārijs, kas pēc daudzu pētījumā intervēto sociālo projektu īstenotāju domām būtu efektīvāks nekā sabiedrības pašiniciatīvas virzītais scenārijs, uzlabojoties tautsaimniecības izaugsmes rādītājiem, ir iespējams. Valsts izglītības un inovāciju politikas jomu pārstāvji, kuri projekta norises laikā tika gan iesaistīti fokusgrupas diskusijās, gan iepazīstināti ar starppētījumu rezultātiem, atzin̄̄gi novērtēja sociālās inovācijas lomu valsts ilgtspējīgas attīstības veicināšanā. Iepazīstoties ar dažādu jomu projektu mērksiem, uzdevumiem un pabeigto projektu rezultātiem, redzams, ka kāds projekts veiksmīgāk, cits mazāk veiksmīgi, bet tomēr ir snieguši ieguldījumu valstij arī kopumā, piemēram, veicinot nodarbinātību un sociālo pakalpojumu pieejamību, iesaistot sabiedrību izglītības pakalpojumu pilnveidē un integrējot bēgl̦us Latvijas sabiedrībā, tādējādi iesaistoties šobrīd Latvijā esošo kopējo sociāli ekonomisko problēmu risināšanā. Pat ja lielākā dalı projektu nav sasnieguši savu finanšu ilgtspēju, tie tomēr ir pievērsuši apkārtējās sabiedrības uzmanību gan sociālajos tīklos, gan NVO kontaktbiržās, un, visbeidzot, to kā vērtīgu pieredzi atzīst lielākā daḷa projektu īstenotāju, norādot, ka tie vēlas turpināt iesākto darbu un izjūt gandarījumu par paveikto.

2. Starp apzinātajiem 115 sociālo inovāciju projektiem Latvijā daži uzṇēmīgi cilvēki tiešām ir spējuši īstenot praksē oriǵinālas idejas, kas īsā laikā pārtapušas organizētā kustībā, kurā ir iesaistīts brīvprātīgo darbs, tiek radīts un sabiedrībai piedāvāts sociāli vēlams produkts. Tomēr šādi sociāli inovatīvi produkti, kuri veiksmes gadījumā gūst atpazīstamību arī ārpus savas vietējās kopienas un ar laiku tiek piedāvāti tirgū līdzās tradicionālajiem komercproduktiem, parasti cenas ziṇā ir nekonkurētspējīgi. Tiem nepieciešams arī lielāks mārketinga un sabiedrības izglītošanas atbalsts, kam nepietiek līdzekḷu. Līdz ar to sociālās inovācijas projektu finanšu ilgtspēja diemžēl ir problemātiska. Šāda situācija Latvijā skaidrojama ar mūsu valsts iedzīvotāju "postpadomju" mentalitāti, ko arī šodienas jaunā paaudze bieži pārmanto no saviem vecākiem. Tā izpaužas kā piesardzīga attieksme pret jauniem un netradicionāliem sadarbības partneriem, skepse pret jauna koncepta sociāli vēlamiem produktiem un pirkumu izvēlē koncentrējoties tikai uz produkta cenu un nevēloties ar savu individuālo rīcību piedalīties nacionāla līmen,a sociālo un vides problēmu risināšanā.

3. Tā kā Latvijā sociālo inovāciju veiksmes stāsti tiek salīdzinoši maz popularizēti, maz ir arī oriǵinālu, jaunu un praktisku ideju, kuras būtu radījuši tieši Latvijas iedzìvotāji paši sev. Lielākā daḷa sociāli inovatīvo ideju ir pārn,emtas no ārvalstīm, adaptējot tās Latvijas apstākḷiem. Kā šḳērslis šādu ideju īstenošanai jāmin kavēšanās ar 

dažādu sabiedrības grupu nevienprātība par to, vai citviet pasaulē efektīva ideja varētu labi darboties arī Latvijas apstākḷos un neradītu pieredze Latvijā: sociālās problēmas šksēršlus, piemēram, nodokḷu iekasēšanā, neradītu nevienlīdzīgu konkurenci u. c. problēmas, kā tas ir "Uber" un "Airbnb" gadījumā. Tādējādi šādu sociālo inovāciju darbības prakse ārvalstīs ir rūpīgi jāizvērtē, iesaistot gan politikas veidotājus, gan sociālos partnerus, lai savlaicīgi identificētu problēmas, kādas šādu ārvalstīs populāru sociāli inovatīvo produktu ieviešana varētu radīt Latvijā, un meklētu iespējas, kā tās novērst. 


\section{SOCIĀLĀS INOVĀCIJAS}

\section{PĒTNIECİBAS UN ATTİSTĪBAS}

\section{PROJEKTI EIROPAS SAVIENĪBĀ}

\section{TĀLIS LAIZĀNS}

Sociālā inovācija ir jauna sociālā prakse, kas daudzās valstīs tiek veiksmīgi pielietota sociālo mērksu sasniegšanai (Franz et al., 2012). Pašlaik šis virziens tiek aktualizēts kā īpaša prioritāte nākamajam ES budžeta plānošanas periodam no 2021. gada, un to nosaka Eiropas stratēgiskais mērķis - panākt ilgtspējīgu un integrējošu izaugsmi, kuras sasniegšanai ir svarīgi panākt:

- augstu nodarbinātības līmeni, īpaši jauniešu vidū;

- nabadzības apkarošanu un nevienlīdzības mazināšanu;

- ievērojamu investīciju palielinājumu prasmju, jaunu zināšanu iegūšanā, kā arī izglītībā un pētniecībā;

- risinājumu migrācijas izraisīto risku novēršanā (AGE, 2017).

Jāatzīst, ka pēc 2008. gada globālās finanšu krīzes ES un Latvijas sabiedrībā ir sākušies procesi, kas liecina par izmaiṇu nepieciešamību. Šobrīd ir sarežğîti paredzēt, kādi izaicinājumi sagaidāmi tuvākajā nākotnē. Vai esam gatavi paplašināt savu redzesloku - īpaši, ja tas saistīts ar sabiedrībā norisošajiem procesiem? Vai Latvijas iedzīvotāji - visdažādāko sociālo grupu pārstāvji - ir gatavi šodienas izaicinājumiem, ko tiem piedāvā procesi tautsaimniecībā un aktuālie globālie notikumi? ES un Latvijā akcentē inovāciju kā visnozīmīgāko izvēli, lai sekmētu ekonomisko izaugsmi, kas savukārt radītu nepieciešamos priekšnosacījumus iedzīvotāju ienākumu stabilitātei un mazinātu Latvijas iedzīvotāju vēlmi pamest valsti, vienlaicīgi risinot briestošo demogrāfisko krīzi - tas ir, tiek uzsvērts tikai "bizness" un tā komerciālais aspekts. Autors uzskata, ka valsts pārvaldes aparātā dominē viedoklis, ka tikai tām pētnieku idejām, kuras var pārtapt komercializējamos produktos vai pakalpojumos, un vienīgi tādām inovācijām, kuras veicina uzṇēmēju konkurētspēju, ir lemts kḷūt par Latvijas veiksmes stāstu. Pēc autora domām, pašreizējās norises liecina, ka mūsu valsts ekonomiskās un sociālās politikas veidotāji bijuši ieinteresēti Eiropas valstu modeḷu analīzē, nav mēǵinājuši Latvijā 
piemērot sociālās inovācijas idejas, un tas jau vairākas desmitgades ir attīstības projekti aktualitāte gan ES, gan Eiropas ziemel̦valstīs - Dānijā, Norvēǵijā, Somijā, Zviedrijā. Sabiedrība jūsmo par skandināvu sasniegumiem izglītības pieejamībā, par šo valstu veselības aprūpes sistēmu, politisko kultūru un sasniegto labklājības līmeni, tostarp mums labākajā gadījumā ir tikai virspusēja izpratne par to, kāda loma labklājības nodrošināšanā ir iedzīvotājiem, to sadarbībai ar vietējām pašvaldībām. Arī Latvijā varētu izrādīties lietderīgi mēgināt "nokopēt" Somijas valsts administrācijā pirms 25 gadiem ieviesto sociālās inovācijas projektu "Somijas nākotnes komiteja" (Committee for the Future, 2018). Jāatzīmē, ka šajā ziemel̦valstī sociālajai inovācijai ir vairāk nekā simts gadu pieredze un sociālās inovācijas pasākumi tiek īstenoti kā vienota sistēma, kas dod iespējas visiem un mēgina izlīdzināt nevienlīdzības sekas.

Latvijas sabiedrībai pašlaik ir aktuāli popularizēt un sniegt dažādus sociālās inovācijas piemērus, analizēt to ietekmi uz sabiedrības dzīvi un tautsaimniecības attīstību. Šādā veidā tiktu dota iespēja meklēt Latvijas iedzīvotāju grupām, uzṇēmējiem un vietējām pašvaldībām atbilstošus risinājumus un nonākt pie Latvijā raksturīgiem sociālās inovācijas īstenošanas pasākumiem.

\subsection{Sociālās inovācijas pieredze Somijā}

Sociālais uzṇēmums ir viens no veidiem, kā realizēt sociālo inovāciju. Sociālie uzṇēmumi var radīt sociālo inovāciju dažādās jomās, t. sk. izglītības, veselības, vides un uzñēmējdarbības attīstībā. Taču sociālo inovāciju var realizēt arī labdarības organizācijas, valsts, pašvaldība, ikviens sabiedrības indivīds. Tomēr jānorāda, ka ne visi sociālie uzṇēmumi ir gatavi iesaistīties sociālajāinovācijā.

Iepazīstoties ar Somijas pēdējo gadu budžetu un tā veidošanas principiem, jānorāda, ka valdība l,oti daudz dara inovācijas un zinātnes attīstībai. To apstiprina fakts, ka valstī gandrīz 4 \% no iekšzemes kopprodukta tiek izmantoti pētniecībai un attīstībai. Ikvienam, kurš ir saistīts ar pētniecību vai inovāciju, ir pazīstamas tādas organizācijas kā Somijas Tehniskais pētniecības centrs (VTT), Somijas Tehnologiju un inovācijas finansēšanas aǵentūra ("Tekes") un Somijas Inovācijas fonds ("Sitra”), kā arī ir zināms par vairāku Somijas augstskolu sasniegumiem dažādos pētījumu virzienos un projektos. Jāatzīmē, ka Latvijas pētnieki ir maz analizējuši šīs ziemel̦valsts sociālās inovācijas risinājumus, n,emot vērā, ka tos var uzskatīt par vienu no galvenajiem faktoriem, kuri ir panākuši valsts pašreizējo labklājību un virzību uz ilgtspējīgu attīstību. Somi atbilstoši savai pieredzei sociālo inovāciju ir iedalījuši vairākos virzienos: valsts un pašvaldību administrācija, sociālā politika, veselības aprūpe, kultūra, 
regiionālā politika, informācijas un citas modernās tehnologijas, sabiedrības problēmas, brīvā laika un izklaides joma (Taipale, 2014).

Pārskats par nozīmīgākajām Somijas sociālajām inovācijām, kuras var dot stimulu Latvijas uzñēmējiem, nevalstiskajam sektoram un pašvaldībām, ir apkopots 9. tabulā. Šajā tabulā, izmantojot valsts ilgtermiṇa pieredzi, ir parādīti raksturīgākie projekti un sabiedrībai aktuālie virzieni. Latvijas valsts kontekstā ir būtiski pieminēt vienu piemēru - Somijas parlamenta Nākotnes komitejas izveidi 1993. gadā un tās lomu ekonomiskās un sociālās stratēgijas dokumentu sagatavošanā, savlaicīgi prognozējot globālo un lokālo norišu ietekmi uz nacionālajām interesēm. Savas pastāvēšanas divdesmit piecos gados šĩ īpašā parlamenta izveidotā komiteja ir rūpējusies, lai Somijai būtu valstiska attīstības vīzija, lai valsts lēmējinstitūcija savos lēmumos īstenotu politiski un tautsaimnieciski aktuālos stratēǵiskās attīstības virzienus, kas atbilstu konkrētā brīža situācijai valstī un būtu saistīti ar globālajiem procesiem.

Papildus šajā tabulā minētajiem piemēriem ir pieejama arī informācija par daudziem mūsdienīgiem Somijā īstenotiem sociālās inovācijas projektiem tādās Latvijai aktuālās jomās kā veselības aizsardzība, kultūra, pašvaldību teritoriju un reǵionu attīstība, pilsoniskās sabiedrības stiprināšana un iedzīvotāju atpūta un izklaide (Taipale, 2014; Bušēvica et al., 2012: 33-36).

Latvijai nozīmīgi ir izvērtēt Somijas pašvaldību sociālās inovācijas piemērus, kas parāda, ka efektīvu reǵionālo sadarbību iespējams īstenot, pastāvot viena līmen,a pašvaldībām, kuras īsteno starpmunicipalitāšu kooperāciju un izdevīgi sadarbojas reǵionālas nozīmes projektos. Latvijā aktuāli ir pielietot kaimiṇu pieredzi uz sociālo inovāciju orientētu biznesa inkubatoru izveidē un atbilstošas sociālās uzṇēmējdarbības infrastruktūras nodrošināšanā. Šim nolūkam Somijā ir izveidotas regionālās attīstības padomes, kurās darbojas vietējo pašvaldību pārstāvji (Taipale, 2014). Jānorāda, ka Skandināvijas valstīs vietējo pašvaldību institūcijas nav uzskatāmas tikai par konkrētas pašvaldības ekonomisko un sociālo interešu pārstāvjiem, bet tās rīkojas kā atbildīgi un uz sadarbību orientēti nacionālās valdības partneri (Knutsen, 2017).

Latvijas panākumu atslēga ir uz zināšanām balstīta sabiedrība. Jaunu zināšanu radīšana ir svarīgs sociāls uzdevums. Zināšanu un izglītības izplatīšana un nodošana sabiedrībai nevar būt tikai valdības funkcija vai tikai privātā kapitāla virzīta aktivitāte. Pašreizējā globālās ekonomikas situācijā tieši zināšanas un uz zināšanām balstīta ekonomika ir noteicošais nacionālās valsts izaugsmes un konkurētspējas faktors. Somijas pieredze sociālās inovācijas projektu īstenošanā, kas saistās ar sociālo politiku un izglītību, ir uzskatāma par nozīmìgu paraugu Latvijas izglītības jomas profesionāḷiem un politikas veidotājiem. 


\section{Sociālās inovācijas projekti Somijā: pārskats (izveidots, izmantojot: Taipale, 2014)}

\begin{tabular}{|c|c|}
\hline Sociālā inovācija & Apraksts \\
\hline \multicolumn{2}{|c|}{ SOMIJAS VALSTS UN PAŠVALDĪBU PĀRVALDES SISTĒMA } \\
\hline $\begin{array}{l}\text { Vienas kameras } \\
\text { parlamenta izveide } \\
\text { un balsošanas tiesību } \\
\text { piešḳiršana sievietēm }\end{array}$ & $\begin{array}{l}\text { İstenots kopš 01.10.1906. } \\
\text { Somija gan nebija pirmā valsts pasaulē, kurā at|̣̄a ba balsot sievietēm. } \\
\text { Somijā 1907. gadā pasaulē pirmā sieviete kluva par parlamenta locekli. }\end{array}$ \\
\hline $\begin{array}{l}\text { Konstitucionālo } \\
\text { tiesību komiteja }\end{array}$ & $\begin{array}{l}\text { Šì institūcija nav identiska konstitucionālajai tiesai. Šai komitejai ir īpašas } \\
\text { likumdevēja tiesības, un tā drīkst sagatavot un iesniegt parlamenta } \\
\text { balsojumam likumus vai likumu grozījumus. }\end{array}$ \\
\hline $\begin{array}{l}\text { Somijas Nākotnes } \\
\text { vīzijas komiteja } \\
\text { (Committee } \\
\text { for the Future) }\end{array}$ & $\begin{array}{l}\text { Izveidota 1993. gadā; tās sastāvā ir parlamenta locekḷi. } \\
\text { Mērḳis - panākt dialogu starp valdību un parlamentu un sagatavot } \\
\text { parlamenta apspriešanai un lēmumu pieṇemšanai Somijas attīstību } \\
\text { nosakošus programmdokumentus. }\end{array}$ \\
\hline $\begin{array}{l}\text { Pašvaldību } \\
\text { pašpārvalde un } \\
\text { neatkarība }\end{array}$ & $\begin{array}{l}\text { Valsts un vietējo pašvaldību atbildības un funkciju nodalījums. } \\
\text { Pašvaldībām ir tiesības noteikt un iekasēt īpašu municipālo nodokli. } \\
\text { Pašvaldību budžeta ieṇēmumu no nodok|̣iem sadalījums: } \\
\text { municipālais nodoklis - } 88 \% \text {; } \\
\text { nekustamā īpašuma nodoklis - } 6 \% \text {; } \\
\text { uzṇēmumu ienākuma nodoklis - } 6 \% \text {. } \\
\text { Ja valsts uzdod pašvaldībai nodrošināt kādu funkciju, tad valstij ir } \\
\text { jāpiešḳir atbilstošs budžeta finansējums. }\end{array}$ \\
\hline $\begin{array}{l}\text { Atklātības } \\
\text { (caurspīdīguma) } \\
\text { princips }\end{array}$ & $\begin{array}{l}\text { 1766. gadā tika pieṇemts Informācijas brīvas pieejamības akts. Mērḳis - } \\
\text { izskaust valstī tolaik pastāvošo augsto korupciju. } \\
\text { Pašlaik Somija un Zviedrija ir valstis ar viszemāko korupcijas līmeni } \\
\text { pasaulē. }\end{array}$ \\
\hline ledzīvotāju reǵistrs & $\begin{array}{l}\text { Visu Somijas iedzīvotāju reǵistrs tika izveidots jau 16. gs. } \\
\text { Somijā kopš 1970. gada pastāv Vienota nacionālā iedzīvotāju informācijas } \\
\text { sistēma. } \\
\text { leguvumi: zemas izmaksas, nav jāveic regulāras iedzīvotāju aptaujas, } \\
\text { tiek nodrošināta datu aizsardzība un drošỉba. Tajā pašā laikā ir pieejama } \\
\text { augstas precizitātes datu bāze tautsaimniecības norišu prognozēšanai. }\end{array}$ \\
\hline $\begin{array}{l}\text { Triju partneru } \\
\text { (tripartism) līgums } \\
\text { un Vienošanās par } \\
\text { ienākumu politiku }\end{array}$ & $\begin{array}{l}\text { Šì pieeja, kas paredz vienošanos starp darba devējiem, darba ṇēmējiem un } \\
\text { valdību, tika ieviesta 1940. gadā un, sākot ar 2012. gadu, ir ieguvusi jaunu } \\
\text { spēku. } \\
\text { Eiropas Komisija (EK), Ekonomiskās sadarbības un attīstības organizācija } \\
\text { (OECD) un Pasaules Ekonomikas forums ir atzinuši, ka Somijā pielietotie } \\
\text { principi ir devuši visefektīvākos rezultātus. }\end{array}$ \\
\hline $\begin{array}{l}\text { Bez korupcijas (no } \\
\text { corruption) }\end{array}$ & $\begin{array}{l}\text { Kopš } 2007 \text {. gada Somija vienmēr ir bijusi ierindota starp pirmajām sešām } \\
\text { valstīm ar vismazāko korupcijas līmeni. }\end{array}$ \\
\hline
\end{tabular}




\section{SOCIĀLĀ JOMA}

Pilsētas bez
graustiem un
nabadzīgo iedzīvotāju
rajoniem

Pašvaldības ir nozīmīgi pilsētu zemes īpašnieki. Piemēram, Helsinkos 70 \% zemes pieder pašvaldībai. Tas dod iespēju noteikt un regulēt municipālos nodoklius.

Pilsētas attīstības plānošana tiek virzīta tā, lai nepie|autu bagātnieku rajonu veidošanu.

Sociālo mājokḷ atbalsta programmu izmantošana.

\begin{tabular}{l} 
Nodibinājums \\
"Y-Foundation" \\
\hline Studentu Mājvietu \\
atbalsta fonds un \\
biedrība \\
("Finland's Student \\
Housing" Ltd)
\end{tabular}
24 stundu servisa
mājoklis Atbalsta un mājokḷ programma bezpajumtniekiem un bēgliem. Fonda īpašie ieguldītāji: koncerns "Alko" un Somijas Azartspēlu asociācija. Inovācija uzsākta ar daḹju valsts atbalsta finansējumu 1960. gados. Biedrība un fonds ir no augstskolām neatkarīgas pašfinansējošas organizācijas. Sākotnējie kredīti, kas tika izmantoti mājokḷ iegādei un būvniecībai, ir atmaksāti.

Pašlaik loti būtiska loma ārvalstu studentu piesaistīšanā, t. i., sadzīves apstāklı un mājoklı nodrošināšanā.

Pašvaldību un valsts subsidēts mājoklis (parasti vienas istabas dzīvoklis) dažādām iedzīvotāju grupām, piemēram, cilvēkiem ar īpašām vajadzībām, slimībām. (Taču šie nav veco laužu pansionāti.)

Daudzdzīvokḷ
mājokḷ īpašuma un
apsaimniekošanas
modelis

Bērnu uzraudzības sistēma (Child Day Care Act) Vienkāršs un tajā pašā laikā progresīvs mājoklu īpašuma tiesības un apsaimniekošanas jautājumus risinošs modelis. Saprotami un nebirokrātiski risinājumi kredītu piesaistīšanā. leviesta apsaimniekotāju sertificēšanas un uzraudzības sistēma. Pastāv speciāls likums kopš 1973. gada. Tas nosaka pašvaldību atbildību un pienākumu nodrošināt dienas uzraudzību (bērnudārza vietu vai bērna uzraudzības pabalstu) ikvienam bērnam.

Brīvpusdienas tiek nodrošinātas visu skolu audzēkṇiem - tās pašlaik ik

Brīvpusdienas skolu dienu saṇem 900000 bērnu un jauniešu.

audzēkṇiem

Pašlaik šì sistēma ir saistīta ar pasākumiem, kas veltīti bērnu un jauniešu liekā svara samazināšanai.

Ekonomiskās
nabadzības
mazināšanas
pasākumi

Likums par garantētu minimālā ienākuma līmeni ikvienam Somijas iedzīvotājam.

Likums par garantētām pamata sociālajām tiesībām.

Nevienlīdzības mazināšanas pasākumi.

1992. gadā to izveidoja luteriskā baznīca. Pamatmērḳis - palīdzēt trūcīgajiem iedzīvotājiem atmaksāt kredītus bankām un ātro kredītu firmām.

Garantiju fonds Somijā pašlaik apmēram 30000 iedzīvotāju ir problēmas ar kredītu atmaksu.

Izveidota "Pirmās palīdzības konsultāciju līnija ātro kredītu ṇēmējiem". 


\subsection{Sociālās inovācijas projektu pieredze Eiropas Savienībā}

Latvijā pastāv nepieciešamie priekšnosacījumi, kas l̦auj attīstīt sociālo inovāciju un tādējādi veicināt sabiedrības labklājību. Pašreizējā ekonomiskajā situācijā valsts administrācijai un uzṇēmējiem sociālā inovācija var izrādīties viens no būtiskākajiem ekonomiskās un sociālās stabilitātes nodrošinātājiem. Ir svarīgi, lai dažādu sociālo grupu pārstāvji kopā ar uzṇēmējiem veidotu sociālos uzṇēmumus. Vienlaicīgi ir jāveic arī virkne izmainu izglītības sistēmā, kas spētu veicināt sociālo inovāciju.

Ieviešot un izveidojot sociālās inovācijas un sociālās uzṇēmējdarbības atbalsta infrastruktūru, svarīgs ir apkalpojamās teritorijas un tajā esošo iedzīvotāju skaits, kā arī šo parametru optimālais kvantitatīvais novērtējums (Dahl \& Tufte, 1973). Praksē ir pierādījies - lai nodrošinātu kādas pašvaldības izaugsmi, vistiešāk tiek ietekmētas divas dimensijas: teritorijā dzīvojošo iedzīvotāju rīcības efektivitāte (citizen effectiveness) un pašvaldības izpildkapacitāte (Bušēvica et al., 2012: 58-67; Pūḳis, 2012). Pirmā dimensija ir saistāma ar rezidentu (teritorijas iedzīvotāju) spēju ietekmēt un kontrolēt pašvaldības deputātu lēmumus. Pastāv zināma pretruna, kas nosaka, ka mazākas pašvaldības iedzīvotāji ir efektīvāki lēmumu iniciatori, bet lielākai pašvaldībai ir pieejama nozīmīga sistēmiskā kapacitāte.

ES institūcijas sociālajai inovācijai un sociālajai uzṇēmējdarbībai nolēma pievērsties, sākot ar 2000. gadu. Eiropas Parlamenta 2009. gada 19. februāra rezolūcija par sociālo ekonomiku (EP, 2009) akcentē sociālās inovācijas un uzñēmējdarbības būtisko nozīmi sociālās atbildības veidošanā, nodarbinātības veicināšanā un visplašāko sabiedrības slān,u ieklıuš̌anas politikas īstenošanā. Rezolūcijā norādīts, ka ES sociālo ekonomiku pārstāv 10 \% no kopējā ES uzṇēmumu skaita, kas veido 6 \% no kopējās nodarbinātības (EP, 2009).

Izpratne par sociālo inovāciju nav ierobežojama ar logiisko saiti "(konkrēta sociālā) problēma - (sabiedrības interesēm atbilstošs) risinājums". Analizējot sociālās inovācijas pieredzi ES un citur, nākas atzīt, ka tā spēj izpausties pilnvērtīgi tikai nepārtraukta, ilglaicīga procesa formā (EESC, 2016; EC, 2013b). Tāpat jāṇem vērā, ka visbiežāk sociāla rakstura problēmām risinājumi meklējami dažādos līmeṇos, kas variē atkarībā no iesaistīto organizāciju juridiskās formas. Sociālās inovācijas daudzlīmeṇu pastāvēšana izriet arī no organizāciju struktūras un to mērksiem, kas ir atšksirīgi, ja salīdzina, piemēram, kooperatīvās sabiedrības, labdarības fondus vai nodibinājumus un privātās kapitālsabiedrības (komercuzṇēmumus). Dažādos avotos tiek akcentēta ne tikai inovācijas procesa nepārtrauktība, bet arī tās "izmērāmā" ietekme jeb mērogs (de Bruin et al., 2013; Hummels, 2018). Daži autori uzsver, ka sociālajai inovācijai jāpanāk kādu 
nozīmīgu pārmaiṇu ieviešana un tai jābūt saistītai ar potenciāli ievērojamām interesēm vai problēmu risinājumiem (Franz et al., 2012). Šādu situāciju raksturojošs piemērs var tikt minēts saistībā ar biodegvielas ieguvi. Pēc savas būtības biodegviela ir alternatīvs produkts fosilajai degvielai, tādēl tās ražošanu var uzskatīt par t. s. "zaḷās" vai atjaunojamās enerǵijas ieguvi. Lai panāktu, ka šāds enerǵijas avots būtiski samazina siltumnīcas gāzu radīto efektu, vajadzīgas milzīgas sējumu platības, kuru raža tiktu izmantota efektīvai bioetanola vai biodīzel̦degvielas pārstrādei. Piemēram, ja ASV visu audzēto kukurūzu izmantotu tikai etanola ražošanā, tiktu nodrošināti tikai 15 \% no transportam nepieciešamās degvielas (USA Department of Energy, 2006), un tostarp tas izsauktu pavisam cita līmeña sociālās problēmas: samazinātos droša pieeja pārtikas izejvielām, pieaugtu bezdarbs laukos, tiktu iznīcinātas nelielās zemnieku saimniecības, rastos nozīmīgas izmain,as apkārtējāvidē.

Iepriekš minētais piemērs parāda ne tikai saites "problēma-risinājums" nozīmīgumu, bet arī to, ka sociālā inovācija ir jāsaista ar zināmu pāreju no viena - zemākā vai vietējā (reǵionālā) - līmeṇa uz daudz plašāku - Eiropas un globālā mērogā. Šāda izpratne apstiprina pieñēmumu, ka sociālā inovācija var tikt uzskatīta par nepārtrauktu procesu, kurā kāda it kā nebūtiska vajadzība ir saistīta ar nepieciešamību mainīt, uzlabot, pat demontēt kādu noteiktu sistēmu.

Šāda pieeja ir paredzēta ES 7. ietvarprogrammas un 8. ietvarprogrammas ("Apvārsnis 2020") pētniecības un inovācijas projektiem, kas ir veltīti sociālās inovācijas un sociālās uzṇēmējdarbības aktualizēšanai Eiropā. Ietvarprogramās šādas ievirzes sadarbība tika aktualizēta pēc 2010. gada, un laikā līdz 2018. gadam ir uzsākti gandrīz 30 pētniecībai, inovācijai un informācijas izplatī̌̌anai veltīti projekti, no kuriem vairāk nekā puse ir jau pabeigti un to rezultāti ir publiski pieejami attiecīgajās vietnēs. Jānorāda, ka Latvijas pārstāvji (pētnieki, sabiedriskā labuma organizāciju pārstāvji, pašvaldības) līdz šim nav iesaistījušies nevienā ES “Apvārsnis 2020" atbalstītā sadarbības iniciatīvā - EK atbalstāmo un īstenoto projektu datubāzēs par ietvarprogrammām Latvijas vārds nebija atrodams.

ES ietvarprogrammu līdz šim atbalstītie projekti ir devuši iespēju pētniekiem tos analizēt un sniegt zinātnisku vērtējumu - kuri faktori ir sociālo inovāciju veicinoši un kuri, gluži pretēji, to bremzē, ierobežo. Atzīstams devums šajā virzienā ir vairāku autoru publikācijas (Bund et al., 2013; Chalmers, 2012; Howaldt et al., 2014; Mendes et al., 2012; Oganisjana, Surikova \& Laizāns, 2015), kurās, izmantojot dažādu valstu un starptautiskās sadarbības pieredzi, ir analizēta sociālā inovācija, dažādi tās aspekti un ietekmes faktori.

10. tabulā ir dots pārskats par sociālajai inovācijai veltītajiem sadarbības projektiem, kuri ir san̄ēmuši ES līdzfinansējumu. Projektu īstenošana ir radījusi dažādas jaunas idejas, metodikas un materiālus, ar kuriem ir 

zētu sociālās inovācijas kustību valstī. 10. tabula var kalpot kā turpmākās izziṇas avots par Latvijā aktuālo un iespējamo rīcības virzienu un atbilstošu scenāriju sagatavošanu. Izmantojot jau īstenoto un pašlaik norisošo projektu datus un materiālus, ir lietderīgi izvērtēt un salīdzināt sociālo inovāciju veicinošos faktorus, kā arī iespējamos negatīvos aspektus. Jāuzsver, ka Eiropā līdz šim lielākā uzmanība ir tikusi pievērsta projektiem, kuri veltīti degradētajām teritorijām, pārtikas resursu saglabāšanai un kvalitātei, kā arī pārrobežu sadarbībai un tehnologiju iespēju izmantošanai sociālajā jomā un sabiedrības iesaistei sociālajā inovācijā.

10. tabula ir sastādīta, vispirms sniedzot pārskatu par pašlaik aktuālajiem un norisošajiem ietvarprogrammas "Apvārsnis 2020" projektiem. Sociālajai inovācijai galvenokārt ir pievērsušās trīs sabiedrības izaicinājumiem veltītās apakšprogrammas: "Pārtikas nodrošinājums, ilgtspējīga lauksaimniecība un mežsaimniecība, jūras, jūrlietu, iekšzemes ūdeņu pētniecība un bioekonomika", "Transports", kā arī "Eiropa mainīgā pasaulē - iekḷaujoša, novatoriska un domājoša sabiedrība". Pēdējā no minētajām apakšprogrammām vairāki projekti ir iniciēti pēdējo divu gadu laikā, tādēl informācija par šo pētījumu rezultātiem netiek izmantota. Līdzīga pieeja bija arī 7. ietvarprogrammai, kad vairums pētījumu bija pārstāvēti apakšprogrammā "Sociālo, ekonomikas un humanitāro zinātṇu pētījumi”. Tabulā ir sniegts vispārīgs pārskats par nozīmīgākajiem projektiem un to mērḳiem, dots īss kopsavilkums par sasniegtajiem rezultātiem, kā arī izvērtēts, kurām sociālajā inovācijā ieinteresētajām personām ir lietderīgi katru no šiem projektiem detalizēti analizēt un iespēju robežās pārṇemt iegūto pieredzi vai uzsākt sadarbību, lai izmantotu pieejamos rezultātus - metodikas, sociālajai inovācijai ieviestās sadarbības platformas, partneru tīklorganizācijas.

Neatliekams uzdevums akadēmiskajai videi un sociālās politikas iniciatoriem ir izvirzìt un noteikt Latvijai aktuālos sociālās inovācijas virzienus un teorētiski pārbaudīt šo virzienu potenciālu jeb ieguvumu. Sākotnēji analizētie dati un informācija liecina par vairākām iespējām, starp kurām īpaši jāpievēršas risinājumiem, kas saistīti ar:

- nevienlīdzības mazināšanu;

- demogrāfiskās situācijas stabilizēšanu;

- veselības aprūpes pakalpojumiem;

- sociālo drošību un sociālajām garantijām, to ieviešanas un izpildes mehānismiem;

- sieviešu nodarbinātības aspektiem, īpaši attiecībā uz līdzvērtīgu darba samaksu;

- darba tirgus sakārtošanu;

- ēnu ekonomikas samazināšanu, izmantojot sociālo inovāciju;

- migrāciju un imigrāciju. 
Pārskats par ES finansētajiem sociālajai inovācijai veltītajiem projektiem 2012.2018. gadā $\bar{a}^{*}$ (izveidots, izmantojot ES 7. ietvarprogrammas un 8. ietvarprogrammas "Apvārsnis 2020" publiski pieejamos datus un projektu mājaslapas)

\begin{tabular}{|c|c|c|}
\hline $\begin{array}{l}\text { ES ietvarprogramma, } \\
\text { apakšprogramma }\end{array}$ & $\begin{array}{c}\text { Projekta rezultātu potenciālie } \\
\text { izmantotāji } \\
\text { (t. sk. Latvijā) }\end{array}$ & $\begin{array}{c}\text { Projekta nosaukums ang|u val. } \\
\text { Akronīms. } \\
\text { Projekta veids }\end{array}$ \\
\hline \multirow{4}{*}{$\begin{array}{l}\text { "Apvārsnis } 2020 " \\
\text { "Sabiedrības izaicinājumi 2: } \\
\text { Pārtikas nodrošinājums, } \\
\text { ilgtspējīga lauksaimniecība } \\
\text { un mežsaimniecība, jūras, } \\
\text { jūrlietu, iekšzemes ūdeṇu } \\
\text { pētniecība un bioekonomika" } \\
\text { (H2O2O } \\
\text { SC2: Food security, sustainable } \\
\text { agriculture and forestry, } \\
\text { marine/water research, } \\
\text { bio-economy) }\end{array}$} & $\begin{array}{l}\text { Lauksaimniecības uzṇēmumi } \\
\text { Sabiedriskā labuma } \\
\text { organizācijas } \\
\text { (SLO) } \\
\text { Augstskolas } \\
\text { Pētnieki }\end{array}$ & $\begin{array}{l}\text { Development of High Quality } \\
\text { Food Protein Through } \\
\text { Sustainable Production } \\
\text { and Processing } \\
\text { Protein2Food } \\
\text { Research and Innovation Actions } \\
\text { (RIA) - Pētniecības un inovācijas } \\
\text { projekts }\end{array}$ \\
\hline & $\begin{array}{l}\text { SLO } \\
\text { Augstskolas } \\
\text { Pētnieki } \\
\text { Lauksaimniecības uzṇēmumi }\end{array}$ & $\begin{array}{l}\text { Social Innovation in Marginalised } \\
\text { Rural Areas } \\
\text { SIMRA } \\
\text { RIA }\end{array}$ \\
\hline & $\begin{array}{l}\text { SLO } \\
\text { Augstskolas } \\
\text { Pētnieki } \\
\text { Politikas veidotāji }\end{array}$ & $\begin{array}{l}\text { Sea Level Change due to Climate } \\
\text { Change } \\
\text { SeaChange } \\
\text { Coordination and Support } \\
\text { Actions (CSA) - Koordinācijas un } \\
\text { atbalsta aktivitāte }\end{array}$ \\
\hline & $\begin{array}{l}\text { SLO } \\
\text { Augstskolas } \\
\text { Pētnieki } \\
\text { Politikas veidotāji }\end{array}$ & $\begin{array}{l}\text { Sustainable Oceans: Our } \\
\text { Collective Responsibility, Our } \\
\text { Common Interest. Building on } \\
\text { Real-Life Knowledge Systems } \\
\text { for Developing Interactive and } \\
\text { Mutual Learning Media } \\
\text { Respon- SEA-ble } \\
\text { CSA }\end{array}$ \\
\hline
\end{tabular}




\begin{tabular}{|c|c|c|}
\hline $\begin{array}{c}\text { Projektā } \\
\text { pārstāvētōs } \\
\text { dalībvalstis }\end{array}$ & $\begin{array}{c}\text { Projekta } \\
\text { îstenošanas laiks }\end{array}$ & Projekta mērḳis \\
\hline $\begin{array}{l}\text { Dānija, Itālija, } \\
\text { Vācija, Īrija, } \\
\text { Spānija, } \\
\text { Zviedrija, Polija, } \\
\text { Beḷ́ija, Francija, } \\
\text { Rumānija, } \\
\text { Nīderlande, } \\
\text { Uganda, Peru }\end{array}$ & 03.2015.-02.2020. & $\begin{array}{l}\text { https://www.protein2food.eu } \\
\text { Projekts pašlaik turpinās. } \\
\text { Projekta mērḳi ir saistīti ar inovatīvu, izmaksām un resursiem } \\
\text { efektīvu un proteīniem bagātu pārtikā izmantojamu } \\
\text { kultūraugu audzēšanas un ǵenētiskajiem pētījumiem, lai } \\
\text { padarītu plaši pieejamu līdz šim maz izmantotu kultūraugu } \\
\text { (lupīna, pupas, zirṇi, lēcas) izmantošanu uzturā. Sociālā } \\
\text { inovācija ir saistīta ar proteīniem bagātu, maz izmantotu } \\
\text { kultūraugu izmantošanas ietekmi uz vidi un socio- } \\
\text { ekonomiskajiem ieguvumiem un riskiem. } \\
\text { Koordinators: Kopenhāgenas Universitāte, Dānija. }\end{array}$ \\
\hline $\begin{array}{l}\text { Lielbritānija, } \\
\text { Itālija, Austrija, } \\
\text { Nīderlande, } \\
\text { Slovākija, Somija, } \\
\text { Spānija, Griek̦ija, } \\
\text { Norvēǵija, } \\
\text { Francija, Čehija, } \\
\text { Šveice, Ēǵipte, } \\
\text { Libāna }\end{array}$ & $04.2016 .-03.2020$ & $\begin{array}{l}\text { https://www.simra-h2020.eu } \\
\text { Projekts pašlaik turpinās. } \\
\text { Projekta mērḳi - izvērtēt sociālās inovācijas iespējas } \\
\text { krīzes skartās un marginālās lauku teritorijās projekta } \\
\text { dalībvalstīs un Vidusjūras reǵiona valstīs. } \\
\text { Paredzēts izveidot digitālas interaktīvās platformas, kas } \\
\text { veicinās sociālās inovācijas projektu pārrobežu ieviešanu un } \\
\text { informācijas nodrošināšanu. } \\
\text { Koordinators: The James Hutton Institute, Lielbritānija. }\end{array}$ \\
\hline Lielbritānija & 03.2015.-02.2018. & $\begin{array}{l}\text { https://www. seachangeproject.eu } \\
\text { Mērḳis - atklāt sabiedrībai saistību, kas pastāv starp } \\
\text { okeānu/jūras "veselību" un cilvēku veselību un labklājību. } \\
\text { Koordinators: Redingas Universitāte (The University } \\
\text { of Reading), Lielbritānija. }\end{array}$ \\
\hline $\begin{array}{l}\text { Francija, } \\
\text { Nīderlande, Īrija, } \\
\text { Norvēǵija, } \\
\text { Portugāle, } \\
\text { Rumānija, Itālija, } \\
\text { Vācija, Spānija, } \\
\text { Lielbritānija, } \\
\text { Griek̦ija }\end{array}$ & 04.2015.-03.2019. & $\begin{array}{l}\text { https://www.responseable.eu } \\
\text { Projekts pašlaik turpinās. } \\
\text { Projekta mērḳis - atklāt, ka zināšanas par jūru un okeānu } \\
\text { kā cilvēcei svarīgu resursu avotu ir nepieciešamas katrai } \\
\text { sociālajai grupai un ikvienam komersantam. Sociālā } \\
\text { inovācija - aktuālu blogu (Ocean literacy blog) izveide un } \\
\text { informācijas apmaiṇa (piemēram, par situāciju Baltijas } \\
\text { jūrā, par iespējamo sadarbību, projektiem, kas virzīti uz } \\
\text { jūras resursu ilgtspēju). } \\
\text { Koordinators: "Acteon Sarl", Francija. }\end{array}$ \\
\hline
\end{tabular}


10. tabulas turpinājums

\begin{tabular}{|c|c|c|}
\hline $\begin{array}{c}\text { ES ietvarprogramma, } \\
\text { apakšprogramma }\end{array}$ & $\begin{array}{c}\text { Projekta rezultātu potenciālie } \\
\text { izmantotāji } \\
\text { (t.sk. Latvijā) }\end{array}$ & $\begin{array}{l}\text { Projekta nosaukums anglu val. } \\
\text { Akronīms. } \\
\text { Projekta veids }\end{array}$ \\
\hline $\begin{array}{l}\text { "Apvārsnis 2020" } \\
\text { "Sabiedrības izaicinājumi 6: } \\
\text { Eiropa mainīgā pasaulē - } \\
\text { ieklaujoša, novatoriska un } \\
\text { domājoša sabiedrība" } \\
\text { (H2020 } \\
\text { SC6: Europe in a changing } \\
\text { world - inclusive, innovative } \\
\text { and reflective societies) }\end{array}$ & $\begin{array}{l}\text { SLO } \\
\text { Augstskolas } \\
\text { Pētnieki } \\
\text { Politikas veidotāji }\end{array}$ & $\begin{array}{l}\text { Social Innovation Community. } \\
\text { SIC } \\
\text { CSA }\end{array}$ \\
\hline $\begin{array}{l}\text { "Apvārsnis 2020" } \\
\text { "Sabiedrības izaicinājumi 4: } \\
\text { Transports" } \\
\text { (H2O2O } \\
\text { SC4 Transport) }\end{array}$ & $\begin{array}{l}\text { SLO } \\
\text { Augstskolas } \\
\text { Pētnieki } \\
\text { Politikas veidotāji }\end{array}$ & $\begin{array}{l}\text { Action Plan for the Future of } \\
\text { Mobility in Europe } \\
\text { MOBILITY4EU } \\
\text { CSA }\end{array}$ \\
\hline \multirow{3}{*}{$\begin{array}{l}\text { 7. letvarprogramma } \\
\text { "Sociālo un ekonomikas un } \\
\text { humanitāro zinātṇu pētījumi" }\end{array}$} & $\begin{array}{l}\text { SLO } \\
\text { Augstskolas } \\
\text { Pētnieki } \\
\text { Politikas veidotāji }\end{array}$ & $\begin{array}{l}\text { Innovating for Social Services } \\
\text { Research } \\
\text { InnoServ } \\
\text { CSA }\end{array}$ \\
\hline & $\begin{array}{l}\text { SLO } \\
\text { Augstskolas } \\
\text { Pētnieki } \\
\text { Politikas veidotāji } \\
\text { Transporta nozare }\end{array}$ & $\begin{array}{l}\text { Building a European Network of } \\
\text { Incubators for Social innovation } \\
\text { BENISI } \\
\text { CSA }\end{array}$ \\
\hline & $\begin{array}{l}\text { SLO } \\
\text { Augstskolas } \\
\text { Pētnieki } \\
\text { Politikas veidotāji }\end{array}$ & $\begin{array}{l}\text { Transnational Network for Social } \\
\text { Innovation Incubation } \\
\text { TRANSITION } \\
\text { CSA }\end{array}$ \\
\hline
\end{tabular}


Projektō

pārstāvētās

dalibvalstis
Projekta

īstenošanas laiks

\section{Projekta mērḳis}

https://www.siceurope.eu

Projekts pašlaik turpinās.

Projekta mērḳis - apvienot sociālās inovācijas organizācijas un tīklus vienotā sistēmā, lai panāktu iespēju risināt kompleksus sociālās inovācijas projektus un nodrošināt ar informāciju politikas veidotājus.

Koordinators: Association Europeenne pour l'information sur le Developpement Local, Beḷ́ija.

https://www.mobility4eu.eu

Projekts pašlaik turpinās.

Mērḳis - izplatīt Eiropas pilsoniskajā sabiedrībā vīziju par Eiropas transporta sistēmu (Vision For Transport Itālija, Spānija, Zviedrija, 01.2016.-12.2018.

Nìderlande, Lielbritānija, Ungārija, Somija 2030). Rezultāti ir saistīti ar rīcības plānu paketēm, kas paredzētas dažādu sabiedrības grupu izmantošanai un iespējamo izaicinājumu analīzei.

Koordinators: "Vdi/Vde Innovation + Technik GmbH", Vācija.

Vācija, Dānija, Norvēǵija, Ungārija, Itālija, Lielbritānija, 02.2012.-01.2014. Francija, Beḷ́ija, ITrija

Beḷgija, Austrija, Lielbritānija, Zviedrija, Rumānija, Nīderlande, Itālija

Belǵija, Francija, Lielbritānija, Īrija, Spānija, 09.2013.-02.2016. 05.2013.-04.2016.

https://www.inno-serv.eu http://innoserv.philnoug.com

Projekta mērḳis - identificēt inovatĩvus sociālos pakalpojumus veselības jomā, izglītības un labklājības nodrošināšanā. Projekta mērḳauditorija mazākumtautības, mazturīgie iedzīvotāji.

Koordinators: Heidelbergas Universitāte, Vācija. http://www.benisi.eu

Mērḳis - izveidot virtuālu vis-Eiropas sociālās inovācijas inkubatoru tīklu, lai nodrošinātu apmēram 300 sociālās inovācijas projektu ieviešanu. Ideja saistīta ar aktualitāti vienā vietā (pilsētā, valstī) uzsāktu projektu izplatīt citās valstīs un reǵionos.

Koordinators: "Propeller NV", Belǵija.

http://transitionproject.eu

Projekta mērḳis ir identisks BENISI projektam. Atšḳirīga ir projekta partneru - dalībvalstu - ǵeogrāfija.

Koordinators: European Business and Innovation Centre Network AISBL, Bel'gija. 
10. tabulas turpinājums

\begin{tabular}{|c|c|c|}
\hline $\begin{array}{l}\text { ES ietvarprogramma, } \\
\text { apakšprogramma }\end{array}$ & $\begin{array}{c}\text { Projekta rezultātu potenciālie } \\
\text { izmantotāji } \\
\text { (t.sk. Latvijā) }\end{array}$ & $\begin{array}{c}\text { Projekta nosaukums ang|u val. } \\
\text { Akronīms. } \\
\text { Projekta veids }\end{array}$ \\
\hline \multirow{3}{*}{$\begin{array}{l}\text { 7. letvarprogramma } \\
\text { "Sociālo un ekonomikas un } \\
\text { humanitāro zinātṇu pētījumi" }\end{array}$} & $\begin{array}{l}\text { SLO } \\
\text { Augstskolas } \\
\text { Pētnieki } \\
\text { Politikas veidotāji }\end{array}$ & $\begin{array}{l}\text { Green Lifestyles, Alternative } \\
\text { Models and Upscaling Regional } \\
\text { Sustainability } \\
\text { GLAMURS } \\
\text { Large-Scale Integrating Project } \\
(C P-I P) \text { - Lielbudžeta integrāciju } \\
\text { veicinošs projekts }\end{array}$ \\
\hline & $\begin{array}{l}\text { SLO } \\
\text { Sociālie uzṇēmēji } \\
\text { Augstskolas } \\
\text { Pētnieki } \\
\text { Politikas veidotāji }\end{array}$ & $\begin{array}{l}\text { Social Enterprise as Force for } \\
\text { More Inclusive and Innovative } \\
\text { Societies } \\
\text { SEFORIS } \\
\text { Small or medium-scale focused } \\
\text { research project (CP-FP) - } \\
\text { Mērkiorientēts pētniecības } \\
\text { projekts }\end{array}$ \\
\hline & 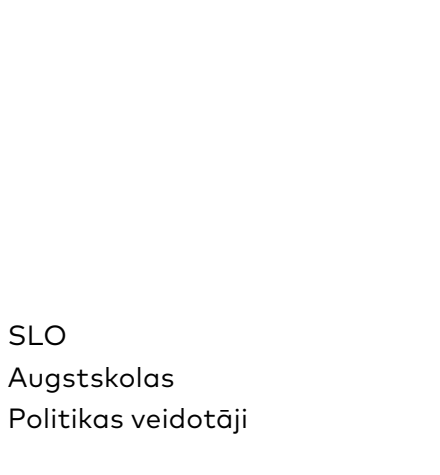 & $\begin{array}{l}\text { Third Sector Impact } \\
\text { TSI } \\
\text { CP-FP }\end{array}$ \\
\hline
\end{tabular}




\begin{tabular}{|c|c|c|}
\hline $\begin{array}{l}\text { Projektā } \\
\text { pärstāvētās } \\
\text { dalībvalstis }\end{array}$ & $\begin{array}{c}\text { Projekta } \\
\text { istenošanas laiks }\end{array}$ & Projekta mērḳis \\
\hline $\begin{array}{l}\text { Spānija, } \\
\text { Lielbritānija, } \\
\text { Norvēǵija, Vācija, } \\
\text { Nīderlande, } \\
\text { Itālija, Rumānija, } \\
\text { Austrija }\end{array}$ & $01.2014 .-12.2016$ & $\begin{array}{l}\text { https://cordis.europa.eu/project/rcn/111220_en.html } \\
\text { Mērḳis - izveidot teorētiskus un uz empīriskiem datiem } \\
\text { radītus modeḷs, kas izmantojami, lai Eiropā tiktu veikta } \\
\text { aktīva pāreja uz ilgtspējīgu un zaḷ dzīvesveidu. } \\
\text { Koordinators: People-Environment Research Group, } \\
\text { University of A Coruña, Spānija. }\end{array}$ \\
\hline $\begin{array}{l}\text { Beḷgija, Vācija, } \\
\text { Lielbritānija, } \\
\text { Zviedrija, } \\
\text { Spānija, Krievija, } \\
\text { Ungārija, } \\
\text { Portugāle, Itālija, } \\
\text { Kīna }\end{array}$ & $01.2014 .-04.2017$ & $\begin{array}{l}\text { http://www.seforis.eu } \\
\text { Starpdisciplinārs projekts. } \\
\text { Mērḳis - izpētīt sociālo uzṇēmumu potenciālās iespējas } \\
\text { ES, lai piesaistītu sociālajā inovācijā un sociālajā } \\
\text { uzṇēmējdarbībā pēc iespējas plašāku ieinteresēto } \\
\text { pušu (stakeholders) loku. Rezultāts - datu bāze un } \\
\text { teorētisku priekšlikumu pakete, kas ir izmantojamas gan } \\
\text { likumdevējiem, gan dažādām organizācijām. } \\
\text { Koordinators: "KU Leuven", Beḷgija. }\end{array}$ \\
\hline $\begin{array}{l}\text { Norvēǵija, } \\
\text { Itālija, Austrija, } \\
\text { Lielbritānija, } \\
\text { Vācija, } \\
\text { Nīderlande, } \\
\text { Itālija, Belǵija, } \\
\text { Francija, Spānija, } \\
\text { Horvātija, Polija }\end{array}$ & 01.2014.-01.2017. & $\begin{array}{l}\text { https://thirdsectorimpact.eu } \\
\text { Projekta mērḳis - izstrādāt un piedāvāt t. s. trešajam } \\
\text { jeb nevalstiskajam sektoram* unikālus atjaunojamos } \\
\text { un ilgtspējīgos resursus sociāla un ekonomiska rakstura } \\
\text { problēmu risināšanai, demokrātijai un pilsoniskai } \\
\text { līdzdalībai Eiropā. Sociālo un ekonomisko grūtību laikā ir } \\
\text { milzīgs spiediens uz valdības budžetu, tādē| šī joma kḷūst } \\
\text { vēl svarīgāka. Tā ir nevis alternatīva valdībai, bet gan } \\
\text { kā pilntiesīgs partneris centienos veicināt ekonomisko } \\
\text { attīstību, aktīvu pilsonību un sociālo kohēziju Eiropā. } \\
\text { Rezultāts - priekšlikumi attiecībā uz nevalstiskā } \\
\text { sektora pieredzi dažādu ierobežojumu un riska faktoru } \\
\text { pārvarēšanā. } \\
\text { Koordinators: Institute for Social Research, Norvēǵija. } \\
\text { * Trešais sektors - pilsoniskās sabiedrības organizāciju } \\
\text { un neformālo grupu kopums, kas pastāv līdzās valsts un } \\
\text { biznesa sektoriem. Sastāv no pilsoniskās sabiedrības } \\
\text { apvienībām un fondiem, brīvprātīgajiem un citām } \\
\text { pilsoniskās sabiedrības organizācijām un aktivitātēm. }\end{array}$ \\
\hline
\end{tabular}


10. tabulas turpinājums

\begin{tabular}{|c|c|c|}
\hline $\begin{array}{l}\text { ES ietvarprogramma, } \\
\text { apakšprogramma }\end{array}$ & $\begin{array}{c}\text { Projekta rezultātu potenciālie } \\
\text { izmantotāji } \\
\text { (t. sk. Latvijā) }\end{array}$ & $\begin{array}{c}\text { Projekta nosaukums ang|u val. } \\
\text { Akronīms. } \\
\text { Projekta veids }\end{array}$ \\
\hline \multirow{3}{*}{$\begin{array}{l}\text { 7. letvarprogramma } \\
\text { "Sociālo un ekonomikas un } \\
\text { humanitāro zinātṇu pētījumi" } \\
\text { (FP7 } \\
\text { Socio-economic sciences } \\
\text { and humanities) }\end{array}$} & $\begin{array}{l}\text { SLO } \\
\text { Augstskolas } \\
\text { Pētnieki } \\
\text { Politikas veidotāji }\end{array}$ & $\begin{array}{l}\text { Social Innovation - Empowering } \\
\text { the Young for the Common Good } \\
\text { SoclEtY } \\
\text { CP-FP }\end{array}$ \\
\hline & $\begin{array}{l}\text { SLO } \\
\text { Augstskolas } \\
\text { Pētnieki } \\
\text { Politikas veidotāji } \\
\text { Sociālie uzṇēmēji }\end{array}$ & $\begin{array}{l}\text { Social Innovation: Driving Force } \\
\text { of Social Change } \\
\text { SI-DRIVE } \\
\text { CP-IP }\end{array}$ \\
\hline & $\begin{array}{l}\text { SLO } \\
\text { Augstskolas } \\
\text { Pētnieki } \\
\text { Politikas veidotāji } \\
\text { Sociālie uzṇēmēji }\end{array}$ & $\begin{array}{l}\text { Theoretical, Empirical and Policy } \\
\text { Foundations for Social Innovation } \\
\text { in Europe } \\
\text { TEPSIE } \\
\text { CP-FP }\end{array}$ \\
\hline
\end{tabular}




\begin{tabular}{|c|c|c|}
\hline $\begin{array}{l}\text { Projektā } \\
\text { pārstāvētās } \\
\text { dalībvalstis }\end{array}$ & $\begin{array}{c}\text { Projekta } \\
\text { İstenošanas laiks }\end{array}$ & Projekta mērḳis \\
\hline $\begin{array}{l}\text { Vācija, } \\
\text { Lielbritānija, } \\
\text { Francija, } \\
\text { Dānija, Itālija, } \\
\text { Nīderlande, } \\
\text { Beḷ́ija, Spānija, } \\
\text { Rumānija, } \\
\text { Austrija, Šveice }\end{array}$ & 01.2013.-12.2015. & $\begin{array}{l}\text { https://www.society-youth.eu } \\
\text { Projekta mērḳis - izveidot un ieviest tādus sociālās } \\
\text { inovācijas risinājumus, kas palīdzētu uzlabot dzīves } \\
\text { kvalitāti jauniem cilvēkiem, kuri ir saskārušies ar veselības } \\
\text { problēmām un jūtas sociāli atstumti. } \\
\text { Koordinators: Bielefeld Center for Education and Capability } \\
\text { Research, Bielefeld University, Vācija. }\end{array}$ \\
\hline $\begin{array}{l}\text { Vācija, } \\
\text { Nīderlande, } \\
\text { Lielbritānija, } \\
\text { Austrija, Spānija, } \\
\text { Horvātija, } \\
\text { Bulgārija, } \\
\text { Zviedrija, } \\
\text { Lietuva, Itālija, } \\
\text { Rumānija, } \\
\text { Austrija, Krievija, } \\
\text { Turcija, Ēǵipte, } \\
\text { Dienvidāfrika, } \\
\text { Kanāda, } \\
\text { Kolumbija, Čīle, } \\
\text { Austrālija, Indija, } \\
\text { Kīna }\end{array}$ & $01.2014 .-12.2017$ & $\begin{array}{l}\text { https://www.si-drive.eu } \\
\text { Rezultāts - zinātnisks pētījums par sociālo inovāciju, } \\
\text { kas īstenots, izmantojot interaktīvu saziṇu ar sociālajā } \\
\text { inovācijā ieinteresētajām pusēm un kopienu tīkliem. Veikta } \\
\text { attiecīgo politikas jomu analīze un politikas un prakses } \\
\text { ieteikumi sociālās inovācijas ieinteresētajām personām, un } \\
\text { tie ir virzīti uz šādu mērḳu sasniegšanu: } \\
\text { - attīstīt sociālo inovāciju kā inovācijas jauno paradigmu; } \\
\text { - sekmēt izmaiṇas sabiedrībā; } \\
\text { - parādīt sociālās inovācijas veiksmes faktorus un } \\
\quad \text { palīdzēt veidot starpvalstu sadarbību sociālās } \\
\text { inovācijas jomā; } \\
\text { atklāt potenciālos sociālās inovācijas šḳēršlus, sniegt } \\
\text { ieskatu par dažādu politikas un citu intervences } \\
\text { instrumentu izmantošanu. } \\
\text { Koordinators: Technische Universität Dortmund, Vācija. }\end{array}$ \\
\hline $\begin{array}{l}\text { Dānija, } \\
\text { Lielbritānija, } \\
\text { Vācija, Griek̦ija, } \\
\text { Portugāle, Polija }\end{array}$ & 01.2012.-12.2014. & $\begin{array}{l}\text { https://toolkit.pe2020.eu/resource/tepsie-project/ } \\
\text { https://youngfoundation.org/projects/tepsie/ } \\
\text { Projekta rezultātā ir izveidotas } 80 \text { sadarbības } \\
\text { organizācijas un inovatīvi risinājumi, kas izmantojami } \\
\text { dažādām partneru vajadzībām, piemēram, The Open } \\
\text { University, Language Line, Social Innovation Exchange, } \\
\text { School for Social Entrepreneurs, Uprising, Action for } \\
\text { Happiness. } \\
\text { Nozīmīgākās programmas ir saistītas ar sociālo inovāciju } \\
\text { nevienlīdzības, jaunatnes un izglītības, kā arī veselības } \\
\text { jomā. } \\
\text { Koordinators: Danish Technological Institute, Dānija. } \\
\text { Zinātniskais vadītājs: The Young Foundation, Lielbritānija. }\end{array}$ \\
\hline
\end{tabular}


10. tabulas turpinājums

\begin{tabular}{|c|c|c|c|}
\hline $\begin{array}{l}\text { ES ietvarprogramma, } \\
\text { apakšprogramma }\end{array}$ & $\begin{array}{l}\text { Projekta rezultātu } \\
\text { potenciālie izmantotōji } \\
\text { (t. sk. Latvijā) }\end{array}$ & $\begin{array}{l}\text { Projekta nosaukums } \\
\text { ang|u val. } \\
\text { Akronīms. } \\
\text { Projekta veids }\end{array}$ & $\begin{array}{c}\text { Projektā pārstāvētās } \\
\text { dalībvalstis }\end{array}$ \\
\hline \multirow{3}{*}{$\begin{array}{l}\text { 7. letvarprogramma } \\
\text { "Sociālo un ekonomikas } \\
\text { un humanitāro zinātṇu } \\
\text { pētijumi" } \\
\text { (FP7 } \\
\text { Socio-economic }\end{array}$} & $\begin{array}{l}\text { SLO } \\
\text { Augstskolas } \\
\text { Pētnieki } \\
\text { Politikas veidotāji } \\
\text { Pašvaldības } \\
\text { Sociālie uzñēmēji }\end{array}$ & $\begin{array}{l}\text { Welfare Innovations } \\
\text { at the Local Level in } \\
\text { Favour of Cohesion } \\
\text { WILCO } \\
\text { CP-FP }\end{array}$ & $\begin{array}{l}\text { Nīderlande, Vācija, } \\
\text { Itālija, Šveice, Spānija, } \\
\text { Horvātija, Lielbritānija, } \\
\text { Francija, Polija, } \\
\text { Zviedrija, Beḷǵija, } \\
\text { Slovākija }\end{array}$ \\
\hline & $\begin{array}{l}\text { SLO } \\
\text { Augstskolas } \\
\text { Pētnieki } \\
\text { Politikas veidotāji } \\
\text { Pašvaldības } \\
\text { Sociālie uzṇēmēji }\end{array}$ & $\begin{array}{l}\text { Poverty Reduction in } \\
\text { Europe: Social Policy } \\
\text { and Innovation } \\
\text { ImPRoveE } \\
\text { CP-FP }\end{array}$ & $\begin{array}{l}\text { Belǵija, Griekijia, } \\
\text { Ungārija, Lielbritānija, } \\
\text { Austrija, Itālija, Somija }\end{array}$ \\
\hline & $\begin{array}{l}\text { SLO } \\
\text { Augstskolas } \\
\text { Pētnieki } \\
\text { Politikas veidotāji } \\
\text { Pašvaldības } \\
\text { Sociālie uzṇēmēji } \\
\text { Lauksaimniecības } \\
\text { produkcijas ražotāji }\end{array}$ & $\begin{array}{l}\text { Food Use for Social } \\
\text { Innovation by } \\
\text { Optimising Waste } \\
\text { Prevention Strategies } \\
\text { FUSIONS } \\
\text { CSA }\end{array}$ & $\begin{array}{l}\text { Nīderlande, Somija, } \\
\text { Lielbritānija, } \\
\text { Itālija, Zviedrija, } \\
\text { Francija, Dānija, } \\
\text { Austrija, Itālija, } \\
\text { Ungārija, Griek̦ija, } \\
\text { Vācija, Turcija }\end{array}$ \\
\hline
\end{tabular}




\begin{tabular}{|c|c|}
\hline $\begin{array}{c}\text { Projekta } \\
\text { istenošanas laiks }\end{array}$ & Projekta mērḳis \\
\hline 12.2010.-01.2014. & $\begin{array}{l}\text { http://www.wilcoproject.eu } \\
\text { Projekta rezultāti ir saistīti ar nevienlīdzības, tās iemeslu un ietekmējošo } \\
\text { faktoru izpēti vairākās Eiropas valstīs. Ir izstrādāta metodika ("WILCO } \\
\text { Project e-Book"), ko var izmantot dažādas sabiedrības grupas, lai meklētu } \\
\text { risinājumus sociālās nevienlīdzības mazināšanai un vispārējās labklājības } \\
\text { veicināšanai. } \\
\text { Koordinators: Radboud University Nijmegen, Nīderlande. }\end{array}$ \\
\hline 03.2012.-02.2016. & $\begin{array}{l}\text { http://improve-research.eu/ } \\
\text { Projekts "Nabadzības mazināšana Eiropā: sociālā politika un inovācija" } \\
\text { (ImPRovE) bija starptautisks projekts, kurā apvienoti desmit pētniecības } \\
\text { institūti un plašs pētnieku tīkls, saskaṇoti cenšoties izpētīt nabadzību, sociālo } \\
\text { politiku un sociālo inovāciju Eiropā. ImPRovE projekta mērḳis ir uzlabot uz } \\
\text { pierādijumiem balstītas nabadzības mazināšanas politikas veidošanas bāzi } \\
\text { Eiropā, ṇemot vērā kā īstermiṇā, tā ilgtermiṇā sasniedzamos rezultātus. } \\
\text { Projekta rezultāti ir jāsaista ar priekšlikumu paketi šādu problēmu risināšanai: } \\
\text { - kā Eiropā var panākt sociālo kohēziju? } \\
\text { - kā sociālā inovācija var papildināt, pastiprināt un mainīt makroekonomisko } \\
\quad \text { politiku un otrādi? } \\
\text { Koordinators: Herman Deleeck Centre for Social Policy, University of Antwerp, } \\
\text { Belǵija. }\end{array}$ \\
\hline 08.2012.-07.2016. & 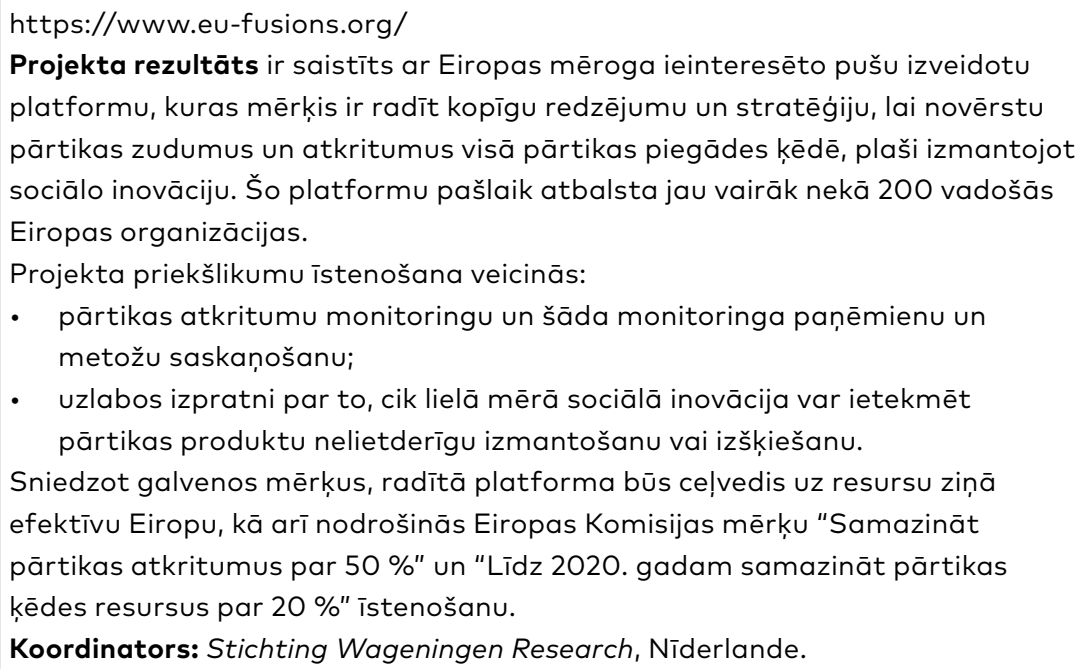 \\
\hline
\end{tabular}


10. tabulas turpinājums

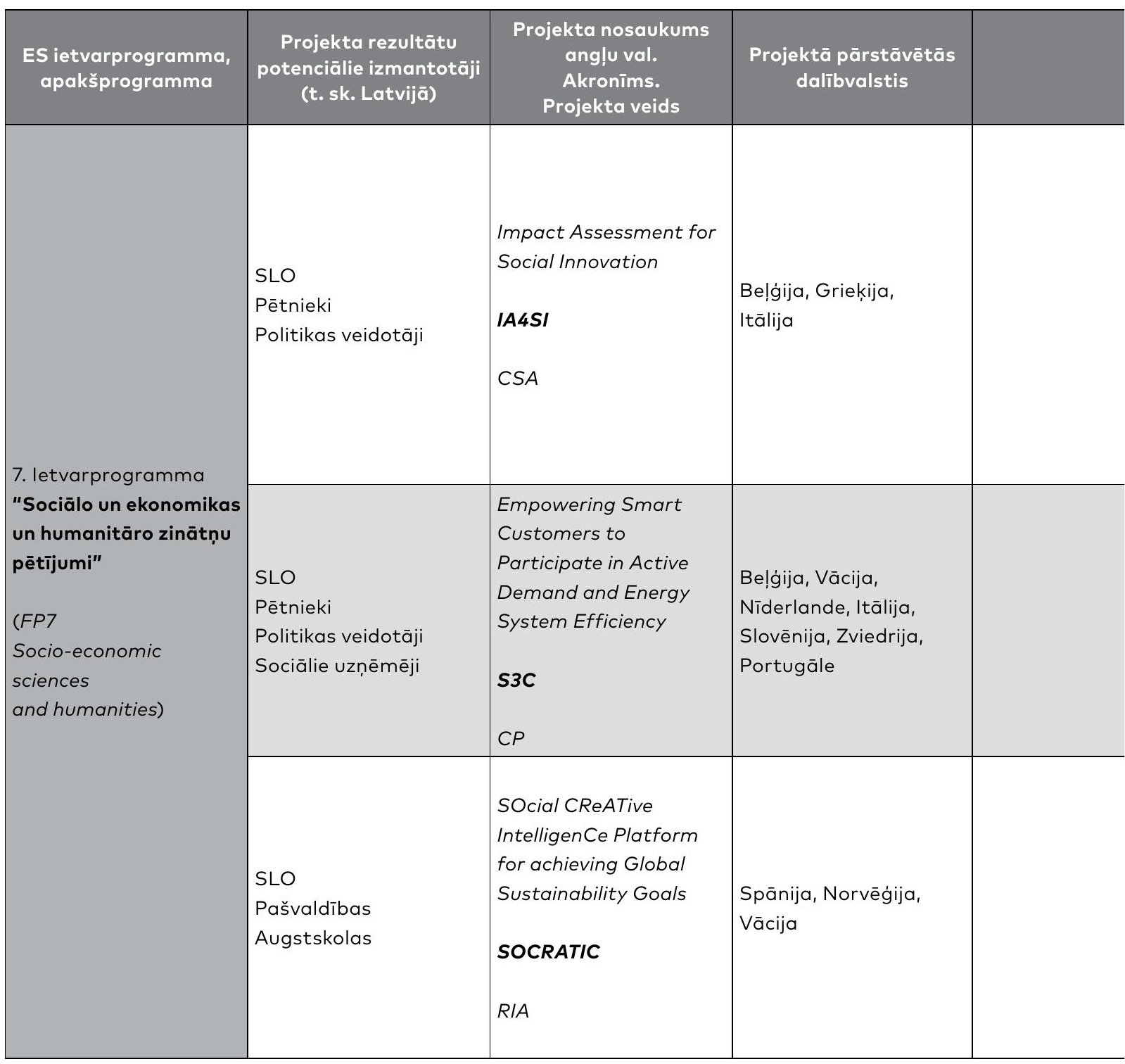




\begin{tabular}{|c|c|}
\hline $\begin{array}{c}\text { Projekta } \\
\text { istenošanas laiks }\end{array}$ & Projekta mērḳis \\
\hline 10.2013.-05.2016. & $\begin{array}{l}\text { http://ia4si.eu/ } \\
\text { Projekta mērḳis ir atbalstīt un piedāvāt zināšanu apmainas un sinerǵiju } \\
\text { attīstības iespējas t. s. kolektīvās izpratnes projektiem. } \\
\text { Projekta īstenošanas galvenie rezultāti: } \\
\text { - pielāgotas sociālekonomiskās ietekmes novērtēšanas metodoloǵijas } \\
\text { konkrētai digitālās sociālās inovācijas jomai (piemēram, SEQUOIA, ERINA+ } \\
\text { un MAXICULTURE); } \\
\text { piedāvāti trīs tiešsaistes rīki ietekmes pašnovērtējumam, kas ḷuj } \\
\text { projektiem izprast un uzlabot to ietekmi uz mērḳiem. Šie trīs instrumenti ir } \\
\text { paredzēti projektiem un Eiropas pilsoniem, kuri piedalās dažādu projektu } \\
\text { novērtēšanā. } \\
\text { Koordinators: "iMinds", Beḷ́ija. }\end{array}$ \\
\hline 11.2012.-10.2015. & $\begin{array}{l}\text { http://www.s3c-project.eu/ } \\
\text { Projekta mērḳis - izpētīt un ieviest enerǵijas patērētāju labas prakses } \\
\text { piemērus, padarīt tos plaši pieejamus visdažādākajām enerǵijas patērētāju } \\
\text { grupām. } \\
\text { legūto datu un pieredzes analīzes rezultātā ir izstrādāts jaunu, optimizētu rīku } \\
\text { kopums un vadlīnijas, kas izmantojamas sabiedrībā, lai veiksmīgi iesaistītu } \\
\text { gan viedos patērētājus, gan viedos klientus un viedos iedzīvotājus. } \\
\text { Koordinators: Vlaamse Instelling voor Technologisch Onderzoek N.V., Belǵija. }\end{array}$ \\
\hline 01.2016.-12.2017. & $\begin{array}{l}\text { https://www.socratic.eu } \\
\text { Izveidota interneta platforma (knowledge-based internet platform), kas dod } \\
\text { iespēju izmantot dažādus rīkus un pakalpojumus, kuri ir noderīgi, īstenojot } \\
\text { kādu sociālās inovācijas projektu. } \\
\text { Projekta mērḳis - nodrošināt pilsoṇus un organizācijas ar praktiski } \\
\text { izmantojamu virtuālo līdzdalības telpu projektiem, kas ir saistīti ar globālās } \\
\text { ilgtspējas risinājumu ieviešanu. } \\
\text { Izstrādāta metodoloǵijas rokasgrāmata "Key for a civil society - led model } \\
\text { towards the sustainable development goals". } \\
\text { Koordinators: "Fundaćion Cibervoluntarios", Spānija. }\end{array}$ \\
\hline
\end{tabular}

* Izveidots, izmantojot ES 7. ietvarprogrammas un 8. ietvarprogrammas "Apvārsnis 2020" publiski pieejamos datus un projektu mājaslapas 
Praktiski visu uzskaitīto problēmu risinājumu idejas var iegūt, iepazīstoties ar EK līdz šim uzsākto un īstenoto sociālajai inovācijai veltīto projektu rezultātiem un plašo informācijas klāstu.

\section{Secinājumi}

Detalizētais Somijas pieredzes izvērtējums, kā arī iepaziššnās ar nesenā pagātnē pabeigtajiem un pašlaik aktuālajiem Eiropas Komisijas atbalstītajiem projektiem, kas veltīti sociālajai inovācijai, l̦auj akcentēt vairākus secinājumus, kā arī izvirzìt priekšlikumus turpmākās attīstības scenāriju izveidei Latvijā.

- Ziemel̦u kaimiṇvalsts Somija ir uzskatāma par piemēru, kā iestrādes un sasniegumi sociālās inovācijas jomā var tikt izmantoti Latvijā.

- Zināšanas un zināšanas izplatošās un nodrošinošās institūcijas veido būtisku Somijas un citu ziemel̦valstu sociālā model̦a dal̦u. Garantējot iespējas iegūt augstāko izglītību, Somijā tiek panākts, ka izglītība un zināšanas ir atzītas par primāru vērtību. Latvijai šāda stratēǵiskā mērḳa noteikšana un sasniegšana ir uzskatāma par vitāli svarīgu.

- Latvijā nepieciešams ieviest nacionāla līmeṇa sociālās inovācijas pilnveidošanas programmu. Tas radītu iespēju plašāka spektra finansējuma pieejamībai, tādējādi paaugstinot valsts un sabiedrības sociālo kapacitāti, veicinātu iesaistīto partneru savstarpējo sadarbību un sinerǵiju un sekmētu sociālekonomiskos ieguvumus.

- Latvijas valdībai sociālās politikas un arī citu programmu izstrādē jāpal̦aujas uz t. s. depolitizētajiem ekspertiem un sociālajiem partneriem, tādējādi veidojot sekmīgu valsts attīstību.

- Ir lietderīgi izmantot un pielietot ES līdzšinējo sociālās inovācijas pieredzi, kā arī iesaistīties ES atbalstītajos pētniecības un informācijas izplatīšanas projektos.

- ES ietvarprogrammu atbalstīto projektu rezultāti ir kvalitatīvs pieredzes un zināšanu avots, īpaši, lai sociālās inovācijas iniciatori Latvijā precīzi spētu noteikt sociālo inovāciju veicinošos faktorus, kā arī savlaicīgi atklātu ierobežojošos faktorus. 


\section{SOCIĀLĀ INOVĀCIJA \\ TĀS GLOBĀLAJĀ KONTEKSTĀ}

\section{NICOLÁS MONGE-IRIARTE}

Šo nodalu ir sagatavojis Nicolás Monge-Iriarte, kurš iekḷāvās Rīgas Tehniskās universitātes pētnieku komandā VPP "EKOSOC-LV" 5.2.7. projekta "Sabiedrības iesaiste sociālās inovācijas procesos Latvijas ilgtspējīgas attīstības nodrošināšanai" trešajā posmā un dalījās savā pieredzē, kas gūta sociālās inovācijas attīstīšanas teorijas un prakses jomā. Tagad Nicolás ir Čīles Ekonomiskās attīstības aǵentūras (Chilean Economic Development Agency (CORFO)) sociālās inovācijas koordinators un ir atbildīgs par politikas pilnveidošanu un piemērošanu visā valstī. Turpinot sadarbību ar kolēǵi no Čîles, palūdzām viṇu dalīties savā redzējumā, kā Latvijā varētu tikt attīstīta sociālās inovācijas politika. Šì nodaḷa originālā tika uzrakstīta anglu valodā, bet tās latviešu valodas versija tika izveidota, apspriežot visas saturiskās nianses ar autoru Skype vidē.

\subsection{Nepieciešamība sniegt valdības atbalstu sociālās inovācijas projektiem}

Kopš Pasaules Vides un attīstības komisijas ziņojuma (the World Commission on Environment and Development report) "Mūsu kopējā nākotne" ("Our Common Future”) publicēšanas Apvienoto Nāciju Organizācija (ANO) ir veicinājusi ilgtspējīgas attīstības koncepcijas īstenošanu. Tā tiek definēta kā "attīstība, kas atbilst pašreizējām vajadzībām, neapdraudot nākamo paaudžu spēju apmierināt savas vajadzības" (World Commission on Environment and Development, 1987:41). Nākamās paaudzes var attīstīties drošībā, harmoniski un realizēt savu potenciālu, ja kopā ar ekonomiskajiem pasākumiem tiek nodrošināta arī atbilstoša sociālā politika un garantēti vides aizsardzības pasākumi.

Šim nozīmīgajam ziṇojumam sekoja ANO izstrādātās stratēǵijas un vadlīnijas, kuru mērksis bija atbalstīt dalībvalstis to ilgtspējīgas attīstības 
veicināšanā; šīs stratēgijas tika aktualizētas un apspriestas ANO organizētajās konferencēs: "Vide un attīstība" (The Rio Earth Summit "Environment and Development") Riodežaneiro (United Nations, 1992), "Pasaules samits par ilgtspējīgu attīstību" (World Summit on Sustainable Development) Johanesburgā (United Nations, 2002) un "Ilgtspējīga attīstība RIO + 20" (Conference on Sustainable Development “RIO + 20") Roidežaneiro (United Nations, 2012).

2000. gadā ANO izvirzīja Tūkstošgades attīstības mērķus (Millennium Development Goals), kas līdz 2015. gadam paredzēja samazināt nabadzību, nabadzīgo iedzīvotāju skaitu, ienākumu atšksirības starp nabadzīgajiem un bagātajiem, nodrošināt visiem iedzīvotājiem pamatizglīî̄bu, kā arī iespēju iegūt vispārējo vidējo vai profesionālo vidējo izglītību, nodrošināt vienādas iespējas sievietēm un vīriešiem, mazināt bērnu mirstību un uzlabot mātes veselību, nodrošināt vides ilgtspēju, palīdzēt cilvēkiem mazāk attīstītajās valstīs, ierobežot HIV/AIDS, tuberkulozes un difterijas izplatību, kā arī citus novēršamus cilvēka nāves cēloṇus (United Nations, 2000).

Pēc visām šìm iniciatīvām un aktivitātēm ANO ir atzinusi daudzus sasniegumus, taču arī uzsver, ka vēl joprojām neatlaidīgi jāatrisina virkne aktuālu problēmu, kā, piemēram, dzimumu nevienlīdzība, milzīgā plaisa starp bagātajiem un nabadzīgajiem un daudz citu problēmu. Tāpēc arī 2015. gadā ANO Ģenerālajā asamblejā tika pieṇemta rezolūciju "Mūsu pasaules pārveidošana: Ilgtspējīgas attīstības programma 2030". Tā nosaka 17 ilgtspējīgas attīstības mērksus (Sustainable Development Goals $(S D G)$ ): visur izskaust nabadzību visās tās izpausmēs, izskaust badu, panākt pārtikas nodrošinājumu un uzlabotu uzturu, veicināt ilgtspējīgu lauksaimniecību, nodrošināt veselīgu dzīvi un sekmēt labklājību jebkura vecuma cilvēkiem, nodrošināt iekḷaujošu un kvalitatīvu izglītību un veicināt mūžizglītības iespējas, panākt dzimumu vienlīdzību (United Nations, 2015; Pārresoru koordinācijas centrs, 2015).

1996. gadā Baltijas jūras valstu padome (Council of the Baltic Sea States) uzsāka sadarbību ilgtspējīgas attīstības jomā, izveidojot programmu "Baltija 21" ("Baltic 21") saskan̄ā ar ANO norādījumiem. "Baltija 21" uzdevums bija veicināt ilgtspējīgu attīstību Baltijas jūras reǵionā atbilstoši $S D G$, koordinējot mērḳus un darbības, kā arī veicinot pārrobežu sadarbību un sadarbību starp ieinteresēto personu grupām (Council of the Baltic Sea States, 2017).

Kā sasniegt šos globālos mērķus? Kā pārveidot un attīstīt savu valsti un pasauli? Kā efektīvi īstenot "Ilgtspējīgas attīstības programmu 2030"? Šo un daudzu citu izaicinājumu pārvarēšanu šodien saista ar inovāciju. Tomēr jāatzīmē, ka tikai ar "tradicionālo" tehnologisko inovāciju, kas, protams, var veicināt ekonomisko izaugsmi, nevar pilnā mērā atrisināt globālās sociālās problēmas, kas prasa jaunas pieejas, metodologijas, 
koncepcijas, problēmu risināšanas līdzekḷus un mehānismus. Tieši sociālā inovācija tiek atzìta par nozīmīgu spēku šo problēmu atrisināšanā, jo, kā apgalvots Eiropas Savienības 7. ietvarprogrammas projektā "SIDRIVE", "Sociālā inovācija ir izgudrojumu izstrāde un jaunu ideju ieviešana ar mērḳi atvieglot (nekavējoties) un atrisināt (līdz galam) sociālās problēmas, kuras ilgtermiṇā ir vērstas uz indivīdu, grupu vai kopienu sociālo iekḷaušanu" (Oeij et al., 2018:6).

Tādējādi lielākā daḷa valstu visā pasaulē, tostarp arī Latvija, ir pievienojušās ANO "Ilgtspējīgas attīstības programmai 2030", un sociālā inovācija ir jāuztver kā efektīvāks veids šo stratēgisko mērķu sasniegšanai.

\subsection{Kā īstenot sociālās inovācijas politiku Latvijā}

Ir daudz veidu, kā realizēt sociālo inovāciju - piemēram, ar uzñēmējdarbību, sabiedrisko iniciatīvu, akadēmiskajiem projektiem. Šādos scenārijos sociālās inovācijas veicināšanai ir vajadzīgs valdības atbalsts, lai samazinātu riskus šāda veida risinājumu radīšanā un ieviešanā praksē un lai sasniegtu ilgtspējīgu attīstību.

Balstoties savā pieredzē sociālās inovācijas attīstībā, īstenošanā un izplatīšanā, autors ir izveidojis ieteikumus efektīvas sociālās inovācijas politikas izveidei Latvijā.

1. Valdībā jāizveido sociālās inovācijas padome (Establish a Social Innovation Board in the Government): ilgtspējīga attīstība ietver ekonomiskos, sociālos un vides aspektus, tāpēc ir svarīgi "savākt pie viena galda" attiecīgās ministrijas un valsts institūcijas, tostarp tās, kuras strādā uzṇēmējdarbības un inovācijas ekosistēmas uzlabošanas jomā.

Padomes mērḳis būs organizēt politiku, izvairoties no dublēšanās, un noskaidrot katras iesaistītās valsts iestādes lomu. Tāpat ir jāapvieno šī politika ar pašreizējām $S D G$ aktivitātēm.

2. Jāizplata sociālās inovācijas koncepcija: sociālā inovācija kā jēdziens (nevis kā prakse) ir jauna, tādēl nepieciešams sagatavot sabiedrību, lai cilvēki varētu izprast tās būtību un nozīmi. Ir vajadzīgi semināri un vietējas apaḷo galdu diskusijas, kā arī masu mediju un sociālo tīklu izmantošana, iesaistot tajos vietējās ieinteresētās personas. Arī tādu pētījumu kā VPP "EKOSOCLV" projekta "Sabiedrības iesaiste sociālās inovācijas procesos Latvijas ilgtspējīgas attīstības nodrošināšanai" rezultātu prezentēšana plašai sabiedrībai un ideju popularizēšana ir patiesi noderīgi pasākumi.

3. Jāizveido programma sociālajiem uzṇēmējiem un inovatoriem: valsts sektors nespēj ātri un efektīvi atrisināt visas sociālās 
problēmas; tam nav pietiekams budžeta finansējums. Priekšlikums ir izmantot to Latvijas sociālo uzñēmēju un inovatoru entuziasmu, enerǵiju, radošumu un motivāciju, kuri jau gadiem strādā šajā jomā un labprāt risina Latvijas sabiedrības problēmas. Šĩ priekšlikuma mērksis ir paātrināt sociālās inovācijas problēmu risināšanu lokāli, ekspertiem strādājot ar sociālajā inovācijā iesaistītajām pusēm un sociālajiem partneriem viṇu dzīvesvietās, nevis laboratorijās vai sociālajos uzṇēmumos. Pilsoniskā sabiedrība, organizācijas, nodibinājumi, augstskolas u. c. ir svarīgi sociālās inovācijas virzītājspēki.

Programma var tikt īstenota četros posmos.

1. Budžeta noteikšana. Pirmkārt, sociālās inovācijas modelim jābūt orientētam uz kādu konkrētu teritoriālu vienību - pilsētu vai reǵionu. Valdībai būtu jānodrošina finansējums (dotācija), kas segtu projekta īstenošanu. Šādas sociālās inovācijas programmas izpildei ir jāveido komanda, kurā ir koordinators, eksperti jautājumos par sociālās inovācijas metodologiju, procesiem un rādītājiem, kā arī citi speciālisti.

2. Vissvarīgākās risināmās problēmas formulēšana. Parasti sociālo problēmu ir daudz un nepietiek līdzekḷu, lai panāktu risinājumu tām visām. Tādēl problēmām jāpiešksir prioritātes atbilstoši sabiedrības vajadzībām. Labākais veids, kā to izdarīt, ir sadarbība ar vietējo pašvaldību un organizācijām, kuras jau ir gatavojušas dažādus pārskatus vai ziṇojumus par problēmām. Pēc tam jāuzaicina ieinteresētās personas uz semināriem un darbnīcām. Šajos pasākumos viṇi saṇems ieskatu par aktuālo problēmu un attiecīgos pieejamos datus. No savas puses šādu pasākumu dalībnieki spēs sniegt papildu datus un informāciju, būtiskus ieteikumus un citas idejas. Visbeidzot, viṇiem būs iespēja izveidot problēmu reitingu un balsojot vienoties par vissvarīgākās problēmas risināšanu un par turpmāk veicamajiem pasākumiem. Problēmām jāatbilst ilgtspējīgas attīstības mērķiem (SDG).

3. Sabiedrības iesaistīšana problēmas risināšanā. Ieteicams veids, kā piesaistīt idejas, ir sociālās inovācijas konkurss. Ir jābūt pieejamai inovācijas atbalsta dotācijai, piemēram, ja nepieciešama prototipu veidošana vai cita specifiska aktivitāte. Pieteikšanās procesā ieteicams organizēt seminārus, lai izskaidrotu sociālās inovācijas būtību, formulētu problēmu, noteiktu instrumentus un iemācītu prototipēšanas metodologiju, palīdzētu izprast jautājumus par projekta ilgtspējību un novērtējuma rādītājiem. Vietējiem ekspertiem un vadītājiem jāpiedalās novērtējuma sagatavošanā, 
lai tādējādi panāktu vietējai specifikai atbilstošu lēmumu pieṇemšanu un projektu ĩstenošanu.

4. Programmas uzraudzība un vērtēšana. Ir svarīgi, lai katram projektam tiktu piemēroti atbilstoši izmērāmi rezultatīvie rādītāji un citi salīdzināmi kritēriji, kas ḷauj vērtēt programmas vai atsevišḳu pasākumu ieguvumus. Jānosaka galvenie darba snieguma rādītāji (Key Performance Indicators), bet vissvarīgākais, uzraugot projektus, ir veikt plānoto rezultātu sasniegšanas gaitu, sekot procesa norisei, lai novērstu radušos šḳēršlus, kuri var ietekmēt gaidāmo iznākumu no projekta vai programmas. Tādējādi pieteikuma iesniegšanas procesā ir jāaizpilda apsekojums. Prototipa ieviešanas stadijā informāciju salīdzina ar vairākām aptaujām (tas ilgst līdz 18 mēnešiem) un ar nobeiguma apsekojumu. Nemot vērā, ka veidlapu aizpilda visi pretendenti, bet tikai dalıa no viṇiem saṇem dotāciju, neatbalstītā grupa var veidot kontrolgrupu. Procesa beigās arī viṇiem būs jāatbild uz aptaujas jautājumiem, lai būtu iespējams salīdzināt un vērtēt programmas rezultātus. Galvenie darba snieguma rādītāji un rezultatīvie rādītāji no katra projekta sniegs vērtīgu informāciju par programmas rezultātiem kopumā.

\section{Secinājumi}

- Sociālajai inovācijai ir liels potenciāls vietējo un globālo problēmu risināšanā un ilgtspējīgas attīstības veicināšanā.

- Sociālās inovācijas veicināšanai valdībā jāizveido padome no dažādu ministriju un valsts institūciju pārstāvjiem un dažādu nozaru ekspertiem un uzṇēmējiem, lai varētu organizēt valsts sociālo politiku un izveidot sociālās inovācijas atbalsta sistēmu.

- Sociālās inovācijas koncepcija ir jāizplata un jāpopularizē, jāsniedz informācija par labas prakses piemēriem, un par to regulāri jāinformē sabiedrība, lai veicinātu izpratni par sociālo inovāciju, tās nozīmīgumu ilgtspējīgas attīstības nodrošināšanā.

- Sociālā inovācija jāīsteno kā vietējas (reǵiona, pašvaldības, pilsētas) nozīmes projekti, panākot šo vidi pārzinošu, galvenokārt vietējo, ekspertu iesaistīšanu to vērtēšanā un izpildes kontrolē. Sadarbībai ar sociālās inovācijas inkubatoriem jākalpo lokāla rakstura sociālās inovācijas veicināšanai, nevis vispārīgu ideju radīšanai.

- Sociālās inovācijas īstenošanai ir lietderīgi veidot programmu ar šādiem četriem posmiem: 
1) vietējās sabiedrības pārstāvju grupas izveide problēmu apkopojuma izveidei;

2) neatliekami risināmās problēmas noteikšana, problēmu hierarhiska saraksta izveide;

3) prototipa vai risinājuma modeḷa izveide neatliekami risināmajai problēmai;

4) projekta īstenošana un rezultātu novērtēšana. 


\section{KOPSAVILKUMS}

Sociālā inovācija Latvijai pašreizējā situācijā ir vitāli svarīgs un ar kompleksiem risinājumiem saistāms pasākumu kopums, kas spēs panākt izmaiṇas sabiedrībā un palīdzēs risināt atseviškāām iedzīvotāju grupām nozīmīgas problēmas. Lai nonāktu pie kvalitatīvām izmaiṇām, ir jārada nacionāla līmen,a programma, kas noteiktu plaša spektra pasākumu kopumu sociālās inovācijas atbalstam. Tā radītu priekšnosacījumus daudzveidīga finansējuma pieejamībai, paaugstinātu valsts un sabiedrības sociālo kapacitāti, kā arī veicinātu iesaistīto partneru sadarbību un sinerǵiju, kas galarezultātā dotu jūtamus sociālekonomiskos ieguvumus. Šobrīd neatliekams akadēmisko institūciju un politikas veidotāju uzdevums ir saistīts ar tādu stratēgisko virzienu noteikšanu, kas sociālās inovācijas īstenotājiem dotu nepieciešamo instrumentu komplektu un nodrošinātu to rīcībspēju. Valdībai sociālās politikas un arī citu programmu izstrādē krietni vairāk ir jāiesaista profesionāli eksperti un sociālie partneri, jo tikai tādējādi var tikt veidota patiesa un uz sabiedrības vajadzību pilnvērtīgu īstenošanu virzīta demokrātija.

Par galvenajiem sociālās inovācijas šķēršlıiem Latvijā tiek uzskatīti atvērtības trūkums citu pieredzei, neprasme sadarboties, atsevišku iedzīvotāju grupu pasivitāte, sākotnējā finansējuma nepietiekamība un informācijas trūkums. Jāatzīst, ka Latvijas sabiedrībā trūkst pieredzes par sociālās inovācijas iespējām, kā arī trūkst šādu ideju veidošanas kultūras un atsevišksos gadījumos arī prasmju sekmīgai uzsākto projektu īstenošanai. Pēdējo gan bieži jāsaista ar nepietiekamu atbalstu, kā arī administratīvo un birokrātisko škēeršlu pastāvēšanu, kas diemžēl ietver arī kvalitatīva tiesiskā regulējuma trūkumu. Lai pārvarētu šādus traucējošos faktorus, sociālās inovācijas projekti izmanto informācijas izplatīšanas, publicitātes un popularizēšanas pasākumus. Savlaicīga komunikācija ar ieinteresētajām pusēm ḷauj veikt nepieciešamo projekta modifikāciju, pilnveidot organizatorisko atbalstu attiecībā uz lēmumu pieṇemšanu papildu ārējā finansējuma piesaistei vai savu finanšu resursu izmantošanai.

Valsts pētījumu programmas "EKOSOC-LV" projekta 5.2.7. "Sabiedrības iesaiste sociālās inovācijas procesos Latvijas ilgtspējīgas attīstības nodrošināšanai" ietvaros veiktie pētījumi dod pamatotu pārliecību par vairākām iespējām, kas var palīdzēt veiksmīgi atrisināt praktiski visas analizētās problēmas. Šāds secinājums gūst apstiprinājumu, izvērtējot Eiropas Komisijas līdz šim atbalstītos sociālajai inovācijai veltītos projektus un to rezultātus. Šodienas sociālekonomiskajā situācijā Latvijā sociālajai inovācijai vairāk atbilst sabiedrības pašiniciatīvas virzìtais 
scenārijs, kas mērkēêts uz risinājuma panākšanu kādai atsevišķai, nelielai sabiedrības grupai. Sociālās inovācijas īstenotājiem, lai saṇemtu finansiālo atbalstu un panāktu informatīvo un organizatorisko atbalstu, nākas paḷauties galvenokārt uz pašu prasmēm un spēkiem, jo tikai atsevišķos gadījumos izdodas iegūt pilnvērtīgu pašvaldības, privāto investoru vai ES struktūrfondu līdzdalību. Šāda situācija ir apliecinājums tam, ka Latvijas sabiedrības iesaiste sociālās inovācijas procesos nav pietiekami nozīmīga un pilnvērtīga. Lai valstī panāktu izpratni par šo procesu nozīmīgumu un izveidotu šai jomai stabilu vidi, ir jānodrošina sociālās inovācijas politika, kas izriet no dažādu iespējamo scenāriju analītiska izvērtējuma.

Viens no svarīgākajiem virzieniem, kas var noteikt sociālās inovācijas attīstību un atbalstu tai, ir saistīts ar nepieciešamību izglìtot sabiedrību un veicināt cilvēku informētību par sociālās inovācijas un sociālās uzṇēmējdarbības iespējām. Šajā aspektā ir svarīgi izplatīt ārvalstu pieredzi, labāko praksi, kā arī parādīt dažādu finansējuma avotu un instrumentu pielietošanas iespējas, jo Latvijā trūkst izpratnes un zināšanu par tiem. Nozīmīga ir izglìtības loma, lai audzinātu cilvēkos atvērtību jaunai pieredzei, veidotu aktīvu dzīves pozīciju, rosinātu ikviena indivīda pilsonisko apzinīgumu un stimulētu radošumu. Šāda pieeja un iegūto prasmju kopums ir akūti nepieciešami, lai ne tikai palīdzētu pārvarēt šķēeššcus sociālās inovācijas veicināšanai, bet arī lai Latvijas sabiedrība patiesi spētu iekḷauties to tautu pulkā, kuras pārstāv Eiropas vērtības. 
In the present situation in Latvia, social innovation is a vital package of measures and complex solutions which will enable to bring about changes in society and help to address the problems of particular groups of the population. In order to achieve qualitative changes in the society, a national program which sets out a broad range of measures to support social innovation should be elaborated. It would create the preconditions for access to a wide range of funding, increase the social capacity of the state and society, and promote cooperation and synergy between the partners involved, which would ultimately bring tangible socio-economic benefits. At the moment, as an urgent task, academic institutions and policy makers are to identify strategic directions that would provide the social innovation implementers with the set of tools they need and ensure their ability to act. The government needs to involve much more professional experts and social partners in designing the social policy and other programs, as only that may lead to a genuine democracy, which is aimed at the realization of a society's needs. The main barriers to social innovation in Latvia are the lack of openness to others' experience, lack of cooperation, passivity of some population groups, lack of initial funding, and lack of information. It must be admitted that in our society, there is a lack of experience and understanding of the possibilities of social innovation, there is also a lack of culture in creating such ideas or, in some cases, skills to successfully implement the projects launched. However, this situation is conditioned also by an inadequate support and the existence of administrative and bureaucratic obstacles, which unfortunately has to be linked to the lack of a qualitative regulatory framework. To overcome such hindrances, social innovation projects most actively undertake information dissemination, and publicity and advertising activities. Timely communication with stakeholders gives the opportunity to make the necessary modification of the project, to improve organizational support, and to take a decision on seeking an additional external financing or coping with one's own financial resources.

The research conducted within the project 5.2.7. "Involvement of the Society in Social Innovation for Providing Sustainable Development of Latvia" of the National Research Programme "EKOSOC-LV" gives reasonable assurance about several possibilities that can help to solve almost all the above analysed problems successfully. This conclusion is confirmed by the evaluation of the social innovation projects supported by the European Commission and their results. In today's 
socio-economic situation in Latvia, social innovation is more in line with the society's self-initiated scenario aimed at reaching solutions for a single, small group of society.

Social innovators need to rely primarily on their own skills and strengths in order to receive financial, informative and organizational support, as it is only in certain cases that they manage to get full support from local governments, private investors, or EU Structural Funds. This situation is a proof that the involvement of Latvian society in social innovation processes is not sufficiently significant and worthwhile. A social innovation policy based on an analytical assessment of different scenarios is needed in order to raise the awareness of the importance of these processes in the country and to create a stable environment for this area.

One of the most important directions for developing and supporting social innovation is related to the need to educate the society and to enhance people's awareness of the opportunities for social innovation and social entrepreneurship. In this respect, it is important to disseminate the experience and best practices of other countries, showing the possibilities of using different sources of funding and tools, since in Latvia people lack awareness and knowledge about them. The role of education is crucially important in educating people and making them more open to new experiences, in creating an active life position, in encouraging civic consciousness of each individual, and in stimulating creativity. Such an approach and the set of acquired skills are vital not only for overcoming the barriers to social innovation but also for enabling the Latvian society to be with the part of nations which truly represent the European values. 


\section{IZMANTOTIE INFORMĀCIJAS AVOTI}

AGE Platform Europe a.i.s.b.l. (2017). AGE Platform Europe Strategy 2018-2021. Retrieved from: https://www.age-platform.eu/sites/default/files/AGE_ Strategy_2018-2021_adopted_by_GA_2017.pdf

Alegre, I., \& Berbegal-Mirabent, J. (2016). Social innovation success factors: hospitality and tourism social enterprises. International Journal of Contemporary Hospitality Management, 28(6), pp. 1155-1176.

Altuna, N., Contri, A.M., Dell'Era, C., Frattini, F., \& Maccarrone, P. (2015). Managing social innovation in for-profit organizations: the case of Intesa Sanpaolo. European Journal of Innovation Management, 18(2), pp. 258-280.

Antadze, N., \& Westley, F. (2010). Funding social innovation: How do we know what to grow? The Philantrophist, 23(3), pp. 343-356.

Benneworth, P., \& Cunha, J. (2015). Universities' contributions to social innovation: reflections in theory \& practice. European Journal of Innovation Management, 18(4), pp. 508-527.

Bessant, J.R., \& Tidd, J. (2011). Innovation and entrepreneurship. 2nd ed. Chichester, West Sussex, UK: Wiley.

Bhatt, P., \& Altinay, L. (2013). How social capital is leveraged in social innovations under resource constraints? Management Decision, 51(9), pp. 1772-1792.

Biedrība „Tuvu”. (2017). Pieejams: http://www.biedribatuvu.lv/gallery/

Bishop, P., Hines, A., \& Collins, T. (2007). The current state of scenario development: an overview of techniques. Foresight, 9(1), pp. 5-25.

BlindArt projekts. (2017). Pieejams: http://blindart.lv

Bloom, P.N., \& Smith, B. R. (2010). Identifying the Drivers of Social Entrepreneurial Impact: Theoretical Development and an Exploratory Empirical Test of SCALERS. Journal of Social Entrepreneurship, 1, pp. 26-145.

Botsman, R. (2015). Defining the sharing economy: what is collaborative consumption and what isn't? Fast coexist. Retrieved from: http://www. fastcoexist.com/3046119/defining-the-sharing-economywhat-is-collaborative-consumption-and-what-isnt

Brown, T., \& Wyatt, J. (2010). Design thinking for social innovation, Stanford Social Innovation Review, Winter: pp. 30-35.

Bugg-Levine, A., Kogut, B., \& Kulatilaka, N. (2010). A New Approach to Funding Social Enterprises. Harward Business Review. Retrieved from: https://hbr. org/2012/01/a-new-approach-to-funding-social-enterprises

Bulut, C., Hakan, E., \& Duygu Seckin, H. (2013). Social Innovation and Psychometric Analysis. Procedia - Social and Behavioral Sciences, 82, pp. 122-130.

Bund, E., Gerhard, U., Hoelscher, M., \& Mildenberger, G. (2015). A methodological framework for measuring social innovation. Historical Social Research / Historische Sozialforschung, Special Issue: Methods of Innovation Research: Qualitative, Quantitative and Mixed Methods Approaches, 40(3/153), pp. 48-78. 
Bund, E., Hubrich, D. K., Schmitz, B., Mildenberger, G., \& Krlev, G. (2013). Report on innovation metrics - Capturing theoretical, conceptual and operational insights for the measurement of social innovation. A deliverable of the project: "The theoretical, empirical and policy foundations for building social innovation in Europe" (TEPSIE), European Commission - 7th Framework Programme. Brussels: European Commission, DG Research.

Bušēvica, K., Kupics, O., Lešinska, A., Litvins, G., Pīpik̦e, R., \& Šimanska, I. (2012). Latvija cẹ̦ā uz sociālo uzñēmējdarbību. Pieejams: http://providus.lv/article_ files/2265/original/SU_gala_9nov.pdf?1352889758

Butkevičienè, E. (2009). Social innovations in rural communities: methodological framework and empirical evidence. Social Sciences, 63(1), pp. 80-88.

Cajaiba-Santana, G. (2013). Social innovation: Moving the field forward. A conceptual framework. Technological Forecasting and Social Change, 82, pp. 42-51.

Caulier-Grice, J., Kahn, L., Mulgan, G., \& Vasconcelos, D. (2010). Study on social innovation. A paper prepared by the Social Innovation eXchange (SIX) and the Young Foundation for the Bureau of European Policy Advisors. Retrieved from: http://youngfoundation.org/wp-content/uploads/2012/10/Study-on-SocialInnovation-for-the-Bureau-of-European-Policy-Advisors-March-2010.pdf

Certo, S.T., \& Miller, T. (2008). Social Entrepreneurship: Key Issues and Concepts. Business Horizons, 51(4), pp. 267-271.

CESifo Group Munich. (2016). Design and Methodology of the Ifo Business Survey in the German Services Sector. Retrieved from: https://www. cesifo-group.de/ifoHome/facts/Survey-Results/Konjunkturtest/ Dienstleistungen/Aufbau-und-Methodik-des-ifo-Konjunkturtest-Dienstleistungen-Deutschland--.html

Chalmers, D. (2012). Social innovation: An exploration of the barriers faced by innovating organizations in the social economy. Local Economy, 28(1), pp. $17-34$.

Chapman, J. (2004). System Failure. Why governments must learn to think differently. London: DEMOS. Retrieved from: http://www.demos.co.uk/files/ systemfailure2.pdf

Clark, J., Good, B., \& Simmonds, P. (2002). Innovation in the public and third sectors. NESTA Innovation Index Working Paper. Retrieved from: https:// www.nesta.org.uk/sites/default/files/kcfinder/files/4.2.InnovationinthePublicandThirdSectors.pdf

Committee for the Future. (2018). Committee for the Future. Retrieved from: https://www.eduskunta.fi/EN/lakiensaataminen/valiokunnat/ tulevaisuusvaliokunta/Pages/default.aspx

Conger, S.D. (2009). Social inventions. The Innovation Journal: The Public-Sector Innovation Journal, 14(2), p. 221.

Cornelius, N., Todres, M., Janjuha-Jivraj, S., Woods, A., \& Wallace, J. (2008). Corporate social responsibility and the Social Enterprise. Springer: Journal of Business Ethics, 81(2), pp. 355-370.

Council of the Baltic Sea States (2017). The Baltic 2030 Action Plan. Retrieved from: http://www.cbss.org 
Dahl, R.A., Tufte, E.R. (1973). Size and Democracy. Stanford, Calif.: Stanford University Press, $148 \mathrm{p}$.

Davies, A. (2014). Spreading Social Innovations: A Case Study Report. A deliverable of the project: "The theoretical, empirical and policy foundations for building social innovation in Europe" (TEPSIE), European Commission - 7th Framework Programme, Brussels: European Commission, DG Research. Retrieved from: http://www.tepsie.eu/images/documents/d72final.pdf

Davies, A., \& Simon, J. (2013a). The value and role of citizen engagement in social innovation. A deliverable of the project: "The theoretical, empirical and policy foundations for building social innovation in Europe" (TEPSIE), European Commission - 7th Framework Programme, Brussels: European Commission, DG Research. Retrieved from: http://www.tepsie.eu/images/documents/ D5.2\%20final.pdf

Davies, A., \& Simon, J. (2013b). Engaging Citizens in Social Innovation: A short guide to the research for policy makers and practitioners. A deliverable of the project: "The theoretical, empirical and policy foundations for building social innovation in Europe" (TEPSIE), European Commission - 7th Framework Programme, Brussels: European Commission, DG Research. Retrieved from: http://www.tepsie.eu/images/documents/tepsie54.pdf

Davies, A., \& Simon, J. (2012). Citizen engagement in social innovation - a case study report. A deliverable of the project: "The theoretical, empirical and policy foundations for building social innovation in Europe" (TEPSIE), European Commission - 7th Framework Programme, Brussels: European Commission, DG Research. Retrieved from: http://www.tepsie.eu/images/ documents/D5.3\%20final.pdf

Day, S.W., \& Jean-Denis, H. (2016). Resource Based View of Social Entrepreneurship: Putting the Pieces Together. Journal of Strategic Innovation and Sustainability, 11(2), pp. 59-69.

de Bruin, A., \& Stangl, E.M. (2013). Social Innovation Continuum: Towards Addressing Definitional Ambiguity. EMES-SOCENT Conference Selected Papers, Liege.

Dedijer, S. (1984). Science- and technology-related social innovations in UNCSTD National Papers. In: C.G. Hedén \& A. King (Eds.), Social innovations for development. Oxford, New York: Pergamon Press, pp. 57-92.

Dobele, L., Grinberga-Zalite G., Kelle L. (2015). Sustainable economic development: scenarios for promotion of social innovation in Latvia. Journal of Security and Sustainability Issues: International Entrepreneurial Perspectives and Innovative Outcomes, 5(2), pp. 149-158. Ind. SCOPUS.

Dover, G. (2011). Social Innovation and Institutional Work: A Study of the Role of Place and Place-Making in Social Innovations for the "Hard-to-House". Dissertation submitted in partial fulfillment of the requirements for the degree of doctor of philosophy in the Faculty of Business Administration. Simon Fraser University, 266 p.

Drayton, W. (2002). The Citizen Sector: Becoming as Entrepreneurial and Competitive as Business. California Management Review, 44(3), pp. 120-132. 
Durand, R. (2003). Predicting a firm's forecasting ability: the roles of organizational illusion of control and organizational attention. Strategic Management Journal, 24(9), pp. 821-838.

Edwards-Schachter, M.E., Matti, C.E., \& Alcántara, E. (2012). Fostering quality of life through social innovation: A living lab methodology study case. Review of Policy Research, 29(6), pp. 672-692.

Emerson, J., \& Bonini, S. (2003). Blended Value Executive Summary. Blended Value Organisation. Retrieved from: www.blendedvalue.org/publications/index. html

EP. (2009). Eiropas Parlamenta 2009. gada 19. februāra rezolūcija par sociālo ekonomiku. Pieejams: http://www.europarl.europa.eu/sides/getDoc. do?pubRef=-//EP//TEXT+TA+P6-TA-2009-0062+0+DOC+XML+V0//LV

European Commission. (2017). Social Innovation as a Trigger for Transformations. The Role of Research. EC: Luxembourg, $110 \mathrm{p}$.

European Commission. (2013a). Guide to social innovation. Regional and Urban Policy, 72 p. Retrieved from: http://s3platform.jrc.ec.europa.eu/ documents/20182/84453/Guide_to_Social_Innovation.pdf/88aac14c-bb154232-88f1-24b844900a66

European Commission. (2013b). Employment and Social Innovation. Social Agenda, 35, 11/2013.

European Commission. (2012). Strengthening social innovation in Europe. Journey to effective assessment and metrics. Written as part of the Social Innovation Europe Initiative.

European Communities. (2011). Empowering people, driving change: Social innovation in the European Union. Bureau of the European Policy Advisers, European Commission.

European Economic and Social Committee. (2016). "Opinion of the European Economic and Social Committee on "Social innovation, networking and digital communication" (own-initiative opinion)". Official Journal of the European Union, 2016/C, 013/16. Retrieved from: <http://eur-lex. europa.eu/ legal-content/EN/TXT/PDF/?uri=CELEX:52014IE4902\&from=EN>

European Union. (2012b). Financing social impact. Funding social innovation in Europe - mapping the way forward. COM, Brussels. Retrieved from: https://youngfoundation.org/wp-content/uploads/2012/10/ Financing-Social-Impact.pdf

European Union \& The Young Foundation. (2010). Study on social innovation. Retrieved from: http://youngfoundation.org/wp-content/uploads/2012/10/ Study-on-Social-Innovation-for-the-Bureau-of-European-Policy-AdvisorsMarch-2010.pdf

Evers, A., Laville, J.L., Borzaga, C., Defourny, J., Lewis, J., Nyssens, M., Pestoff, V. (2004). Defining the Third Sector in Europe. In: A. Evers, \& J.L. Laville (Eds.), The Third Sector in Europe (pp. 11-42). London: Edward Elgar.

Franz, H-W., Howaldt, J., \& Hochgerner, J. (2012). Challenge social innovation: Potentials for business, social entrepreneurship, welfare and civil society. Springer: Berlin, Heidelberg. 384 p. 
Freeman, C. (1988). Japan: A new national innovation system? G. Dosi, R. Nelson, G. Silverberg \& L. Soete (Eds.), Technology and Economy Theory. London: Pinter Publishers, pp. 31-54.

Frias, N., Aparicio, S., \& Borda, M.L. (2013). Barriers and incentives for social innovation in Colombia: Towards the construction of a public policy. Social Frontier: The next edge of social innovation research, pp. 1-16.

Harker, P.T., \& Vargas, L.G. (1987). The Theory of Ratio Scale Estimation: Saaty's Analytic Hierarchy Process. Management Sciences, 33(1), pp. 1383-1403.

Haugh, H. (2005). A Research Agenda for Social Entrepreneurship. Social Enterprise Journal, 1(1), pp. 1-12.

Heller, C. (2014). The social innovation revolution. Print, 68(3), pp. 40-43.

Hernandez, Y., \& Cormican, K. (2016). Towards the effective management of social innovation projects: Insights from project management. Procedia Computer Science, 100, pp. 237-243.

Hillgren, P.A., Seravalli, A., \& Emilson, A. (2011). Prototyping and infrastructuring in design for social innovation. CoDesign, 7(3/4), pp. 169-183.

Howaldt, J., Butzin, A., Domanski, D., \& Kaletka, C. (2014). Theoretical Approaches to Social Innovation - A Critical Literature Review. A deliverable of the project: "Social Innovation: Driving Force of Social Change" (SI-DRIVE). Dortmund: Sozialforschungsstelle. Retrieved from: http://www.si-drive.eu/ wp-content/uploads/2014/11/D1_1-Critical-Literature-Review.pdf

Howaldt, J., \& Jacobsen, H. (2010). Soziale Innovation. Auf dem Weg zu einem postindustriellen Innovationsparadigma. Wiesbaden: Springer Fachmedien, pp. 71-84.

Howaldt, J., \& Schwarz, M. (2010). Social Innovation: Concepts, research fields and international trends. IMO international monitoring. Aachen. Retrieved from: http://www.sfs-dortmund.de/odb/Repository/Publication/ Doc\%5C1289\%5CIMO_Trendstudie_Howaldt_Schwarz_englische_Version. pdf.

Huber, G., \& Gürtler, L. (2004). AQUAD 6: Manual for the analysis of qualitative data. Ingeborg Huber Verlag, Tübingen, Germany.

Hubert, A. (coord.) et al. (2011). Empowering people, driving change: Social innovation in the European Union. Bureau of the European Policy Advisers, European Commission.

Hummels, H. (2018). The 18th SDG: Social Entrepreneurship in a Global Society. Utrecht University, Utrecht. 92 p.

Institute for Supply Management. (2016). ISM Report On Business. Retrieved from: https://www.instituteforsupplymanagement.org/pubs/content. cfm?Item Number $=10706 \&$ SSO $=1$

Jauns.lv (2017). Kalnciema ielā bēg̣̣i māca, kā gatavo garšīgākos ēdienus no vinuu zemēm. Žurnāls "Kas jauns", 29.04.2017. Pieejams: http://jauns.lv/raksts/ zinas/240123-kalnciema-iela-begli-maca-ka-gatavo-garsigakos-edienusno-vinu-zemem

Jēgere, M. (2015). Pierīgā plašumā vēršas zemnieku produktu tiešās pirkšanas kustība. Pieejams: http://www.aprinkis.lv/sabiedriba/veseliba/item/25316tiesas-pirksanas-pulcini-latvija 
Jensen, S.S., Phillips, L., \& Strand, D.L. (2012). Virtual worlds as sites for social and cultural innovation. Convergence: The International Journal of Research into New Media Technologies, 18(1), pp. 3-10.

Jeroščenkova, L. (2016). Kultūras mantojuma izmantošana lauku tūrisma attīstībā: promocijas darba kopsavilkums ekonomikas doktora (Dr. oec.) zinātniskā grāda iegūšanai. Latvijas Lauksaimniecības universitāte. 124 lpp.

Jiménez Escobar, J., \& Morales Gutiérrez, A.C. (2011). Social economy and the fourth sector, base and protagonist of social innovation. CIRIEC - España, Revista de Economía Pública, Social y Cooperativa, 73, pp. 33-60.

Kacou, E. (2011). Entrepreneurial solutions for prosperity in BoP markets. Strategies for business and economic transformation. Upper Saddle River: Wharton School Pub.

Kay, L. (2017). World's first social impact bond achieved goals and repaid investors. Retrieved from: https://www.thirdsector.co.uk/worldsfirst-social-impact-bond-achieved-goals-repaid-investors/finance/ article/1440676

Khutrakun, A. (2013). Process and Dynamics of Social Innovation: Case Studies of Local Initiatives in Northern Thailand. Japan Social Innovation Journal, 3(1), pp. 12-18.

Klein, J.L., Fontan, J.M., Harrisson, D., \& Levesque, B. (2012). The Quebec system of social innovation. A focused analysis on the local development field. Finisterra: Revista Portuguesa de Geografia, 47(94), pp. 9-28.

Klievink, B., \& Janssen, M. (2014). Developing Multi-Layer Information Infrastructures: Advancing Social Innovation through Public-Private Governance. Information Systems Management, 31(3), 240-249.

Knutsen, O. (ed.) (2017). The Nordic Models in Political Science. Challenged, but Still Viable? Fagbokforlaget: Oslo. 296 p.

Koch, P., \& Hauknes, J. (2005). On innovation in the public sector - today and beyond. Publin Report No. D20, 2nd revised edition. Oslo: NIFU STEP. Retrieved from: http://brage.bibsys.no/xmlui/bitstream/ handle/11250/226573/d20-innovation.pdf?sequence=1

Krlev, G., Bund, E., \& Mildenberger, G. (2014). Measuring what matters indicators of social innovativeness on the national level. Information Systems Management, 31(3), pp. 200-224.

Kudiṇs, V. (2012). Jaunas vēsmas vietējās attīstības jautājumu risināšanā. Latvijas lauku forums, 3/2012. E-izdevums. Pieejams: http://www.llf. partneribas.lv/resource/1356701708_3_e-izdevums.pdf

Kustība “Tiešā pirkšana”. (2017). Pieejams: http://www.tiesapirksana.lv/

Latvijas lauku attīstības programma 2014.-2020. gadam. Pieejams: https://www. zm.gov.lv/zemkopibas-ministrija/statiskas-lapas/latvijas-lauku-attistibasprogramma-2014-2020-gadam-?id=6426\#jump

Latvijas nacionālās attīstības plāns 2014.-2020. gadam. Pieejams: http://www. varam.gov.lv/lat/pol/ppd/ilgtsp_att/?doc $=13858$

Latvijas Republikas Patentu valde. (2015). Izgudrojumi, preču zīmes un dizainparaugi. Latvijas Republikas Patentu valdes oficiālais izdevums. Pieejams: http://www.lrpv.gov.lv/sites/default/files/20151220.pdf

Leadbeater, C. (1997). The Rise of Social Entrepreneurs. London. 
Le Ber, M.J., \& Branzei, O. (2010). (Re)forming strategic cross-sector partnerships: Relational processes of social innovation. Business \& Society, 49(1), pp. 140-172.

Lee, E.K. (2017). Engaging citizens in society. Social Innovation and Social Transition in East Asia, Spring, pp. 16-18.

Limburg, D. (2014). Social innovation through information provision. Human Resource Management, Social Innovation and Technology, 14, pp. 21-36.

Li, Y., Sun, Y., \& Lin, K. (2012). Social innovation, local governance and social quality: The case of intersectoral collaboration in Hangzhou City. International Journal of Social Quality, 2(1), pp. 56-73.

Mahdjoubi, D. (1997). Social innovation: integrating learning and technological innovation, the mapping of innovation. Retrieved from: http://www.ischool. utexas.edu/ darius/map_inov.pdf

Mahmuda, I., Baskaran, A., \& Pancholi, J. (2014). Financing social innovation for poverty reduction: A case study of microfinancing and microenterprise development in Bangladesh. Science, Technology \& Society, 19(2), pp. 249-273.

Makare, M. (2012). Par labāku pasauli. Providus domnīca. Pieejams: http:// providus.lv/article/par-labaku-pasauli

Mancabelli, R. (2012). Looking for 21st-century schooling? District Administration, 48(6), p. 74.

Mariani, E. (2011). The Big European Society: Proposal for a European Social Innovation Act. European Citizen Action Service. Retrieved from: http:// www.ecas.org/wp-content/uploads/2014/09/The-Big-European-Society.pdf

Mayring, P. (2000). Qualitative content analysis. Forum: Qualitative Social Research Theories (on-line journal), Vol. 1, No. 2. Retrieved from: http:// www.utsc.utoronto.ca/ kmacd/IDSC10/Readings/text\%20analysis/CA.pdf

McCarthy, D.D.P., Whitelaw, G.S., Westley, F.R., Crandall, D.D., \& Burnett, D. (2014). The Oak Ridges Moraine as a social innovation: Strategic vision as a social-ecological interaction. Ecology \& Society, 19(1), pp. 385-396.

McVoy, E.C. (1940). Patterns of diffusion in the United States. American Sociological Review, 5(2), pp. 219-227.

Meissner, P., \& Wulf, T. (2012). Cognitive benefits of scenario planning: Its impact on biases and decision quality. Technological Forecasting and Social Change, 80(4), pp. 801-811.

Mendes, A., Batista, A., Fernandes, L., Macedo, P., Pinto, F., Rebelo, L., Ribeiro, M., Ribeiro, R., Sottomayor, M., Tavares, M., \& Verdelho, V. (2012). Barriers to social innovation. A deliverable of the TEPSIE project. Brussels: European Commission, DG Research.

Miller, M.L. (2010). Obstacles to innovation: Experience of the family independence initiative. Working paper prepared for the Executive Session on Transforming Cities through Civil Entrepreneurship. Cambridge: MA.

Minks, M. (2011). Social Innovation: New Solutions to Social Problems. A Thesis submitted to the Faculty of the School of Continuing Studies and of yhe Graduate School of Arts and Sciences in partial fulfillment of the requirements for the degree of Master of Arts in Liberal Studies. 
Moore, M.L., \& Westley, F. (2011). Surmountable chasms: Networks and social innovation for resilient systems, Ecology and Society, 16(1): 5. Retrieved from: http://www.ecologyandsociety.org/vol16/iss1/art5/

Moulaert, F., \& Nussbaumer, J. (2005). The social region. European Urban \& Regional Studies, 12(1), pp. 44-64.

Mulgan, G. (2007). Ready or not? Taking innovation in the public sector seriously. NESTA Provocation, 03, April. Retrieved from: http://www.nesta. org.uk/sites/default/files/ready_or_not.pdf

Mulgan, G. (2006). The process of social innovation. Innovations: Technology, Governance, Globalization, 1, pp. 145-162.

Mulgan, G., \& Albury, D. (2003). Innovation in the public sector. London: Prime Minister's Strategy Unit/Cabinet Office. Retrieved from: http://www. childrencount.org/documents/Mulgan\%20on\%20Innovation.pdf

Mulgan, G., Ali, R., Halkett, R., \& Sanders, B. (2007a) In and out of sync: The challenge of growing social innovations. Retrieved from: http://www.nesta. org.uk/sites/default/files/in_and_out_of_sync.pdf

Mulgan, G., Tucker, S., Rushanara, A., \& Sanders, B. (2007b). What it is, why it matters, how it can be accelerated. Oxford: Oxford Said Business School. Retrieved from: http://www.nj.gov/state/programs/pdf/faith-based-socialinnovation.pdf

Mulgan, G., Wilkie, N., Tucker, S., Ali, R., Davis, F., \& Liptrot, T. (2006). Social silicon valleys - a manifesto for social innovation. Retrieved from: http://www. anobium.es/docs/gc_fichas/doc/5IMOVYfjkw.pdf

Murray, R., Caulier-Grice, J. \& Mulgan, G. (2010). Ways to design, develop and grow social innovation: The open book of social innovation. The Young Foundation \& NESTA. Retrieved from: http://youngfoundation.org/wp-content/ uploads/2012/10/The-Open-Book-of-Social-Innovationg.pdf

Narasimhan, R. (1983). An Analytical Approach to Supplier Selection. Journal of Purchasing and Materials Management, 19(1), pp. 27-32.

Nicholls, A., \& Cho, A.H. (2006). Social Entrepreneurship: the Structuration of a Field. In: A. Nicholls (Ed.), Social Entrepreneurship: New Models of Sustainable Social Change, pp. 99-118. New York: Oxford University Press.

Nichols, N., Phipps, D.J., Provençal, J., \& Hewitt, A. (2013). Knowledge mobilization, collaboration, and social innovation: Leveraging investments in higher education. Canadian Journal of Nonprofit \& Social Economy Research / Revue canadienne de recherche sur les OSBL et l'économie sociale, 4(1), pp. 25-42.

Nussbaum, M. (2003). Beyond the Social Contract: Toward Global Justice. The Tanner Lectures on Human Values, pp. 414-507. Retrieved from: https:// tennerlectures.utah.edu/_documents/a-to-z/n/nussbaum_2003.pdf

OECD (2013). Innovative learning environments. Series: Educational Research and Innovation. Centre for Educational Research and Innovation, OECD Publishing.

OECD (2010). SMEs, Entrepreneurship and Innovation. Series: OECD Studies on SMEs and Entrepreneurship, OECD Publishing.

OECD (2008). Innovating to learn, learning to innovate. Centre for Educational Research and Innovation, OECD Publishing. 
Oeij, P., Van der Torre, W., Vaas, S., \& Dhondt, S. (2018). Understanding Social Innovation as an Innovation Process. Research carried out during the EU-FP7 Project "SI-Drive, Social innovation: Driving force of social change", 2014-2017. Retrieved from: https://www.si-drive.eu/

Oeij, P.R.A., Dhondt, S., \& Korver, T. (2011). Workplace innovation, social innovation, and social quality. International Journal of Social Quality, 1(2), pp. 31-49.

Oganisjana, K., Surikova, S., Kozlovskis, K., \& Svirina, A. (2018). Financial, organisational and informative involvement of the society in social innovation processes in Latvia. Entrepreneurship and sustainability issues, 6(1), pp. 456-471.

Oganisjana, K., Eremina Y., Gvatua, S., Kabwende, B.N., \& Chukwu, O.J. (2017a). Barriers to Social Innovation and Ways of Overcoming Them in Latvia. Journal on Systemics, Cybernetics and Informatics: JSCI, 15(5), pp. 33-38. Retrieved from: http://www.iiisci.org/journal/sci/issue.asp?is=ISS1705

Oganisjana, K., \& Surikova, S. (2015). Social innovation in the promotion of sustainable development of the contemporary Latvian society. Journal of Security and Sustainability Issues, 5(2), pp. 249-258.

Oganisjana, K., Surikova, S., \& Grīnberga-Zālīte, G. (2016). Sociālās inovācijas izpēte starpdisciplinārā skatījumā. Latvijas Zinātṇu Akadēmijas Vēstis, 70. $s \bar{e}$., Nr. 3, 68.-76. lpp. ISSN 1407-0081.

Oganisjana, K., Surikova, S., Kozlovskis, K., \& Svirina, A. (2018). Financial, organisational and informative involvement of the society in social innovation processes in Latvia. Entrepreneurship and Sustainability Issues, 6(1), pp. 456-471.

Oganisjana, K., Surikova, S., \& Laizāns, T. (2015). Factors Influencing Social Innovation Processes in Latvia: Qualitative Research Perspective. The International Journal Entrepreneurship and Sustainability Issues, 3(2), pp. 186-197.

Oganisjana, K., Svirina, A., Surikova, S., Grīnberga-Zālīte, G., \& Kozlovskis, K. (2017b). Engaging universities in social innovation research for understanding sustainability issues. Entrepreneurship and sustainability issues, Vol. 5, No. 1, pp. 9-22. ISSN 2345-0282 (online). Ind. Web of Science.

Ortega, S., Furr, N., Liman, E., \& Flint, C. (2014). The science of social impact innovation: How to deliver more impact through innovative business models. International Journal of Innovation Science, 6(2), pp. 73-82.

Osburg, Th., \& Schmidpeter, R. (2013). Social Innovation: Solutions for a Sustainable Future. (Eds.) Springer-Verlag Berlin Heidelberg. 335 p.

Pārresoru Koordinācijas Centrs. (2015). ANO Ilgtspējīgas attīstības mērḳi. Retrieved from: https://www.pkc.gov.lv/lv/valsts-attistibas-planosana/anoilgtspejigas-attistibas-merki

Pfeffer, J. (1993). Barriers to the advance of organizational science: paradigm development as a dependent variable. The Academy of Management Review, 18(4), pp. 599-620.

Phillips, W., Lee, H., Ghobadian, A., O'Regan, N., \& James, P. (2015). Social innovation and social entrepreneurship: A systematic review. Group \& Organization Management, 40(3), pp. 428-461. 
Phills, J.A., Deiglmeier, K., \& Miller, D.T. (2008). Rediscovering social innovation. Stanford Social Innovation Review, 6(4), pp. 33-43. Retrieved from: http:// ssir.org/images/articles/2008FA_feature_phills_deiglmeier_miller.pdf

Pilvere, I., Nipers, A., Krievina, A., Upīte, I., \& Grīnberga-Zālīte, G. (2014). Latvijas pārtikas nozares konkurētspējas rādītāju salīdzinoša analīze. Latvija, Lietuva, Igaunija, Polija un Krievija. Jelgava: Latvijas Lauksaimniecības universitāte. $200 \mathrm{lpp}$.

Počs, R., Lāce, N., Oganisjana, K. et al. (2018). Ekonomiskā attīstība. B. Rivžas red. Simtam pāri. Viedā Latvija. Valsts pētījumu programma EKOSOC-LV. Latvijas Zinātṇu akadēmija, 153.-247. lpp.

Pol, E., \& Ville, S. (2009). Social innovation: buzz word or enduring term? Journal of Socio-Economics, 38(6), pp. 878-885.

Porter, M.E. (1998). Competitive Advantage - Creating and Sustaining Superior Performance. Free Press. 592 p.

Pot, F., \& Vaas, F. (2008). Social innovation, the new challenge for Europe. International Journal of Productivity and Performance Management, 57(6), pp. 468-473.

Pūḳis, M. (2012). Sociālās uzṇēmējdarbības attīstības iespējas Latvijā. Rīga, Latvijas Pašvaldību savienība.

Raišienè, A.G. (2012). Sustainable development of interorganizational relationships and social innovations. Journal of Security and Sustainability Issues, 2(1), pp. 65-76.

Rockefeller Foundation. (2018). Retrieved from: https://www. rockefellerfoundation.org/

Rüede, D., \& Lurtz, K. (2012). Mapping the various meanings of social innovation: towards a differentiated understanding of an emerging concept. EBS Business School Research Paper Series, 12(03), p. 52.

Rūse, M. (2017). Dalīšanās ekonomika - tradicionālās ekonomikas ienaidnieks vai glābējs? Latvijas Banka. Pieejams: https://www.makroekonomika.lv/ dalisanas-ekonomika-tradicionalas-ekonomikas-ienaidnieks-vai-glabejs

Russon Gilman, H. (2017). The moment for participatory democracy. Stanford Social Innovation Review. Retrieved from: https://ssir.org/articles/entry/ the_moment_for_participatory_democracy

Saaty, T.L. (1994). Fundamentals of Decision Making and Priority Theory with the Analytic Hierarchy Process. RWS Publications. 477 p.

Saaty, T.L. (1977). A scaling method for priorities in hierarchical structures. Journal of Mathematical Psychology, 15(3), pp. 234-281.

Sanzo-Perez, M.J., Álvarez-González, L.I., \& Rey-García, M. (2015). How to encourage social innovations: A resource-based approach. The Service Industries Journal, 35(7-8), pp. 430-447.

Schwartz, P. (1996). The Art of the Long View: Planning for the Future in an Uncertain World. New York: Currency Doubleday. 272 p.

Seyfang, G., \& Smith, A. (2007). Grassroots innovations for sustainable development: towards a new research and policy agenda. Environmental Politics, 16(4), pp. 584-603.

Sitra. (2018). The Finnish Innovation Fund "Sitra". Retrieved from: https:// www.sitra.fi/en/ 
Social Innovation Fund - SIF. (2018). SIF Equality Fund. Retrieved from: https http://www.socialinnovation.ie/equality-fund/

Stewart, R.B. (1981). Regulation, Innovation, and Administrative Law: A Conceptual Framework. California Law Review, 69(5), pp. 1256 -1377.

Surikova, S., Oganisjana, K., \& Grinberga-Zalite, G. (2015). The role of education in promoting social innovation processes in the society. In: Velta Lubkina and Svetlana Usca (Eds.), Society. Integration. Education. Proceedings of the International Scientific Conference, May 22nd-23rd, 2015, Vol. IV, Rēzekne: Rēzeknes Augstskola. pp. 233-243. Retrieved from: http://dx.doi. org/10.17770/sie2015vol4.337

Šūmane, S. (2010). Lauku inovācija: jaunu attīstības prakšu veidošana. Bioloǵiskas lauksaimniecības piemērs. Promocijas darbs sociologijas doktora grāda iegūšanai. Rīga: Latvijas Universitāte, Sociālo zinātṇu fakultāte, Sociologijas nodalı. 206 lpp.

Taipale, I. (Ed.) (2014). 100 Social Innovations from Finland. Helsinki: Finnish Literature Society, $351 \mathrm{p}$.

Tanimoto, K., \& Doi, M. (2007). Social innovation cluster in action: a case study of the San Francisco Bay Area. Hitotsubashi Journal of Commerce and Management, 41(1), pp. 1-17.

TEPSIE. (2014). Building the social innovation ecosystem. A deliverable of the TEPSIE project. Brussels: European Commission, DG Research.

The Economist \& Intelligence Unit. (2013). Old problems, new solutions: Measuring the capacity for social innovation across the world. An Economist Intelligence Unit study. Retrieved from: https://www.essmart-global.com/ wp-content/uploads/2016/12/2016.09.29-Economist-Social-InnovationIndex.pdf

The Young Foundation. (2012a). Social Innovation Overview - Part I: Defining social innovation. A deliverable of the project: "The theoretical, empirical and policy foundations for building social innovation in Europe" (TEPSIE), European Commission - 7th Framework Programme, Brussels: European Commission, DG Research. Retrieved from: http://www.tepsie.eu/images/ documents/TEPSIE.D1.1.Report.DefiningSocialInnovation.Part $\% 201 \% 20$ -\%20defining\%20social\%20innovation.pdf

The Young Foundation. (2012b). Social Innovation Overview - Part II: Practices and Trends. A deliverable of the project: "The theoretical, empirical and policy foundations for building social innovation in Europe" (TEPSIE), European Commission - 7th Framework Programme, Brussels: European Commission, DG Research. Retrieved from: http://www.tepsie.eu/images/ documents/TEPSIE.D1.1Report.DefiningSocialInnovation.Part\%202\%20 -\%20practices $\% 20$ and $\% 20$ trends.pdf

Thom, N. (1990). Innovation management in small and medium-sized firms. Management International Review, 30(2), pp. 181-192.

Tidd, J., \& Bessant, J. (2010). Managing innovation. 4th edition. West Sussex: John Wiley \& Sons Ltd., $622 \mathrm{p}$.

Ümarik, M., Loogma, K., \& Tafel-Viia, K. (2014). Restructuring vocational schools as social innovation? Journal of Educational Administration, 52(1), pp. 97-115. 
United Nations. (2015). Transforming our world: the 2030 Agenda for Sustainable Development. Retrieved from: https://sustainabledevelopment. un.org/

United Nations. (2012). Conference on Sustainable Development - RIO + 20 . Retrieved from: http://www.uncsd2012.org/about.html

United Nations. (2002). World Summit on Sustainable Development: Johannesburg Declaration on Sustainable Development. Retrieved from: http://www.un-documents.net/jburgdec.htm

United Nations. (2000). Millennium Development Goals. Retrieved from: http:// www.undp.org/content/undp/en/home/sdgoverview/mdg_goals.htm

United Nations. (1992). The Rio Earth Summit: Summary of the United Nations Conference on Environment and Development. Retrieved from: http:// publications.gc.ca/Collection-R/LoPBdP/BP/bp317-e.htm

USA Department of Energy. (2006). On the Road to Energy Security, Implementing a Comprehensive Energy Strategy.

Uzṇēmums "Hopp" ražo velosipēdus cilvēkiem, kuriem ir kustību traucējumi. (2014). Financenet. Pieejams: http://financenet.tvnet.lv/ nozares/519311-uznemums_hopp_razo_velosipedus_cilvekiem_kuriem_ir_ kustibu_traucejumi

Van der Geest, L., \& Heuts, L. (2008). Barriers to innovation. In: Nooteboom, B., \& Stam, E. (Eds.) Micro-foundations for Innovation Policy. Amsterdam: Amsterdam University Press, pp. 173-198.

Van der Heijden, K. (2005). Scenarios: The Art of Strategic Conversation. New York: Wiley. $381 \mathrm{p}$.

Van der Heijden, K., Bradfield, R., Burt, G., Cairns, G., \& Wright, G. (2002). The Sixth Sense: Accelerating Organizational Learning with Scenarios. New York: John Wiley \& Sons. 320 p.

VTT (2018). Technical Research Centre of Finland Ltd. Retrieved from: https:// www.vttresearch.com/

Westley, F., Antadze, N., Riddell, D.J., Robinson, K., \& Geobey, S. (2014). Five configurations for scaling up social innovation: Case examples of nonprofit organizations from Canada. The Journal of Applied Behavioral Science, 50(3), pp. 234-260.

W.K. Kellogg Foundation. (2018). Retrieved from: https://www.wkkf.org/

World Commission on Environment and Development. (1987). Our Common Future. Oxford: Oxford University Press.

Young, H.P. (2011). The dynamics of social innovation. Proceedings of the National Academy of Sciences of the United States of America, Vol. 108, Supplement 4: Dynamics of Social, Political, and Economic Institutions, pp. 21285-21291.

Yunus, M. (2007). Creating a World Without Poverty. Social Business and the Future of Capitalism. New York: United States of America.

Zapf, W. (1991). The role of innovations in modernization theory. International Review of Sociology, 1(3), pp. 83-94.

"Žēlsirdības māja" - mājas alternatīva jauniešiem invalīdiem. (2013). Pieejams: https://www.socialauznemejdarbiba.lv/stasti-par-socialajiem-uznemejiem/ fonds-zelsirdibas-maja 


\section{Latvijas Republikas Patentu valdē reǵistrētais produkts "Piramīdu komplekts pētniecībai un socializācijai"}

Latvijas Republikas Patentu valdē 2015. gada 20. decembrī tika registrēts produkta "Piramīdu komplekts pētniecībai un socializācijai" dizainparaugs, reg. Nr. D15587, dizaineri Karine Oganisjana (RTU) un Agnese Irbe (SIA “FInehouse"). "Try \& See” cikla ietvaros izveidotais produkts "The secret power of pyramids" paredzēts kritiskās domāšanas, pētniecisko prasmju un socializācijas veicināšanai sabiedrībā (Latvijas Republikas Patentu valde, 2015, 1925.-1926. lpp.).

\section{Reǵistrētie dizainparaugi}

Šajā sadaḷā Patentu valde turpina publicēt oficiālos paziṇojumus par dizainparaugu reǵistrācijām, kas veiktas atbilstoši 2004. gada 28. oktobra Dizainparaugu likumam. Publikắcijas ir sakărtotas registrắcijas numuru secỉbă. Katra publikăcija satur datus, kas dizainparauga reǵistrācijas brīđī ieḳ̣auti Valsts regiistra ziṇās, kā arī đizainparauga attēlu vai attēlus.

Dizainparauga reǵistrăcija ir spēkā piecus gadus, skaitot no pieteikuma đatuma. Šim termiṇam beidzoties, reǵistrāciju var atjaunot ikreiz uz jaunu piecu gadu periodu lídz dizainparaugu aizsardzỉbas maksimālajam termiṇam - 25 gádiem no pieteikuma datuma (Dizainparaugu likums, 31. pants). Ar dienu, kad registrētais dizainparaugs publicēts (datums, kas norădîts katras lappuses augšmală), pilnă apjomă stăjas spēkā dizainparauga īpašnieka tiesỉbas (Dizainparaugu likums, 12. pants).

Ar publikăcijas dienu iestājas iebildumu periods. lebildumu var iesniegt triju mēnešu laikā pễc publikācijas, pamatojoties uz Dizainparaugu likuma 37. panta pirmãs dạas 1., 2., 4., 5., 6., 7. vai 8. punkta noteikumiem (Dizainparaugu likums, 28. pants).

Starptautiski pieñemtie kodi (INID kodi), kas izmantoti dizainparaugu bibliogrắfisko datu identificēšanai:

(11) Registrăcijas numurs

Registration number

(15) Reǵistrācijas datums

Registration date

(21) Pieteikuma numurs

Application number

(22) Pieteikuma datums

Filing date of the application

(23) Izstādes prioritātes dati

Exhibition priority data

(28) Dizainparaugu skaits kompleksă registrăcijă

Number of designs included (in case of multiple registration)

(30) Konvencijas prioritātes dati:

pieteikuma numurs, pieteikuma datums, valsts kods

Convention priority data:

(11) Reǵ. Nr. D 15587

(21) Pieteik. Nr. D-15-48

(72) Dizaineri Agnese IRBE (LV)

Karine OGANISJANA (LV)

(73) İpašnieks RIIGAS TEHNISKÃ UNIVERSITĀTE; Kaḷ̦u iela 1, Rĩga, LV-1658, LV

(54) PIRAMIIDU KOMPLEKTS PẼTNIECĪBAI UN SOCIALIZĀCIJAI UN ŠĨ KOMPLEKTA IEPAKOJUMS

1.01
(51) LOC kl. 9-03, 19-07, 21-01 (15) Reǵ. dat. 20.12.2015

(22) Pieteik.dat. 19.10.2015

Latvijas Republikas Patentu valdes ekspertīzes lēmums. 
appiıcatıon number, nuıng date, code or country

(46) Publikăcijas atlikšanas termiṇš Deferment expiration term

(51) Dizainparaugu starptautiskās klasifikācijas (Lokarno klasifikâcijas, saīs. LOC) indeksi: klase, apakšklase

Indication of International Classification for Industrial Designs (Locarno Classification - LOC): class, subclass

(54) Izstrâdājuma nosaukums / izstrādājumu nosaukumi Indication of product(s) covered

(58) Reǵistrẫcijas grozījumu ieraksta datums (ippašumtiesỉbu păreja, grozijumi vărdos, nosaukumos vai adresẽs, reǵistrācijas darbỉbas pẳrtraukšana u.tml.)

Date of recording of a transaction in respect of the registration (change in ownership, change in name or address, termination of protection, etc.)

(62) Dati par sakotnêjo pieteikumu, no kura šis pieteikums nodalits

Data of the initial application from which the present application has been divided up

(72) Dizainers / dizaineri, valsts kods Designer(s), code of country

(73) Tipašnieks / ĩpašnieki, adrese, valsts kods Name and address of the owner(s), code of country

(74) Parstâvis (patentpilnvarotais, dizainparaugu aǵents), adrese Representative (attorney), address

(78) Jaunais ĩpašnieks / jaunie ĩpašnieki, adrese, valsts kođs (īpašumtiesību maiñas gadijumă)

Name and address of the new owner(s), code of country (in case of change in ownership)

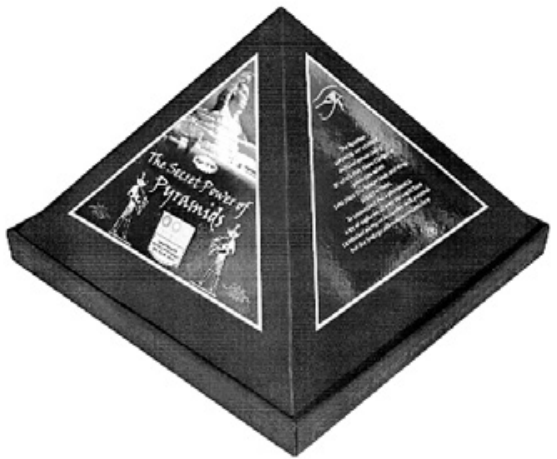

1.02

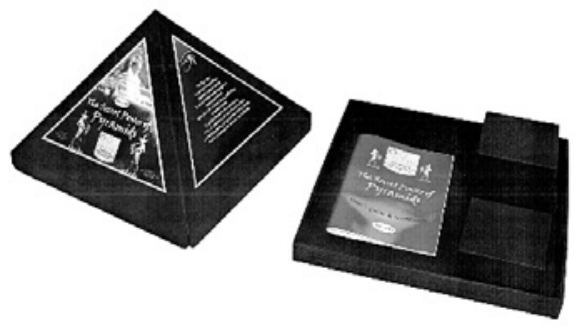

1.03

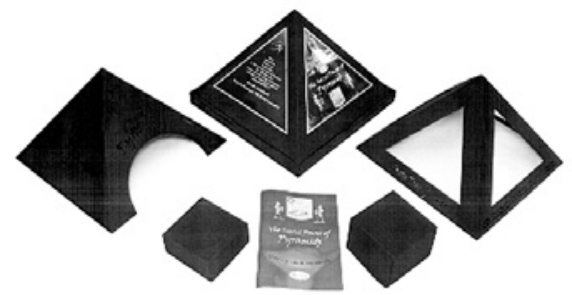

1.04

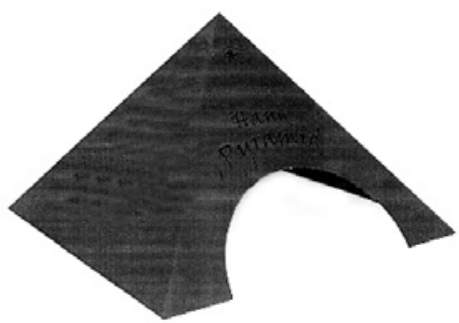

(51) LOC kl. 32-00

(11) Reğ. Nr. D 15588

(15) Reg. dat. 20.12.2015

(21) Pieteik. Nr. D-15-50

(72) Dizainers Antra AUZIN̦A (LV)

(73) İpašnieks TALSU NÓVADA PAŠVALDĪBA; Kareivju iela 7. Talsi, Talsu novads, LV-3201, LV

(54) ORNAMENTS

(28) Dizainparaugu skaits 2

1.01

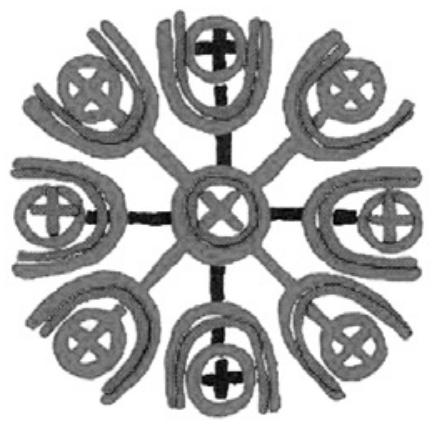




$$
\Delta
$$


